PAULA CARPINTERO DE MORAES

\title{
Resposta microbiana a perturbações naturais em sedimentos costeiros
}

Tese apresentada ao Instituto

Oceanográfico da Universidade de São Paulo, como parte dos requisitos para obtenção do título de Doutor em Ciências, Programa de Oceanografia Biológica.

Orientador:

Prof. Dr. Paulo Yukio Gomes Sumida 
Universidade de São Paulo

Instituto Oceanográfico

\title{
Resposta microbiana a perturbações naturais em sedimentos costeiros
}

\author{
Paula Carpintero de Moraes
}

Tese apresentada ao Instituto Oceanográfico da Universidade de São Paulo, como parte dos requisitos para obtenção do título de Doutor em Ciências, área de Oceanografia Biológica.

\author{
Julgada em
}




\section{SUMÁRIO}

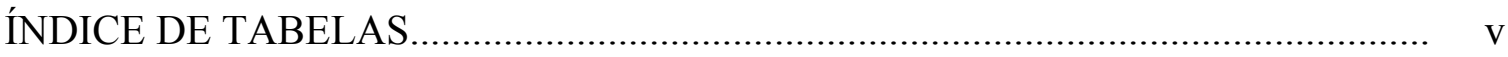

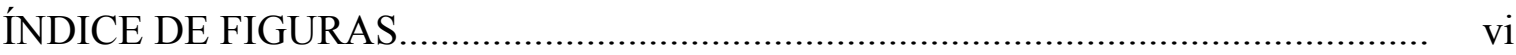

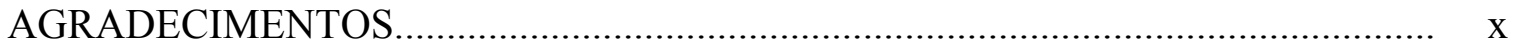

RESUMO

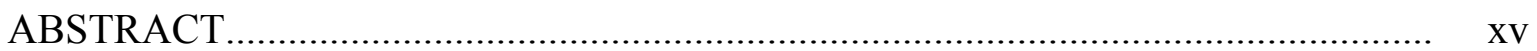

\section{Capítulo 1: Introdução Geral}

1.1.Introdução

1.2.Detalhamento da área de estudo e justificativa da proposta.............................. 5

1.3.Detalhamento do desenho experimental...................................................... 8

1.3.1.Coleta do material e montagem experimental .................................................... 11

Capítulo 2: Efeito da matéria orgânica derivada do plâncton na comunidade microbiana de sedimentos costeiros marinhos

2.1.Introdução ................................................................................................ 17

2.2.Material e Métodos................................................................................. 19

2.2.1.Área de estudo ........................................................................................... 19

2.2.2.Amostragem e montagem experimental.......................................................... 19

2.2.3.Fluxo de Oxigênio......................................................................................... 20

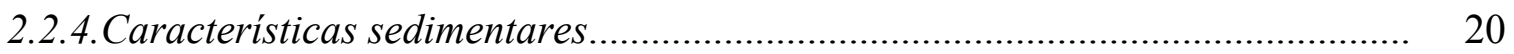

2.2.5.Densidade de procariotos................................................................................... 21

2.2.6. Extração do DNA, PCR e DGGE.................................................................. 21

2.2.7. Sequenciamento das bandas de DGGE e análise filogenética.......................... 22

2.2.8.Análises estatísticas....................................................................................... 22

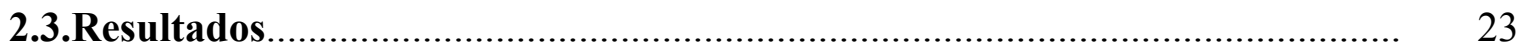

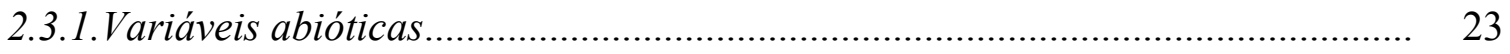


2.3.2.Densidade de procariotos................................................................................ $\quad 26$

2.3.3.DGGE e diversidade bacteriana .................................................................. 28

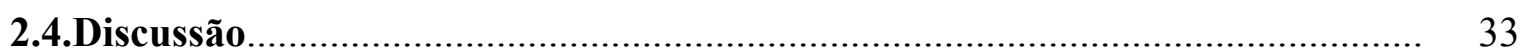

2.4.1.Parâmetros abióticos......................................................................................... 33

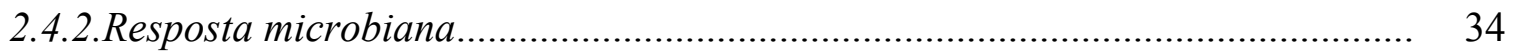

Capítulo 3: Influência do enriquecimento orgânico na distribuição vertical dos micro-organismos na coluna sedimentar marinha costeira

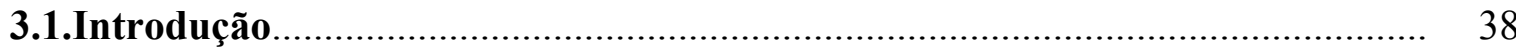

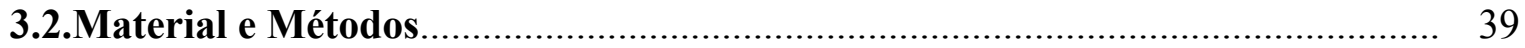

3.2.1.Área de estudo .......................................................................................... 39

3.2.2.Amostragem e montagem experimental......................................................... 40

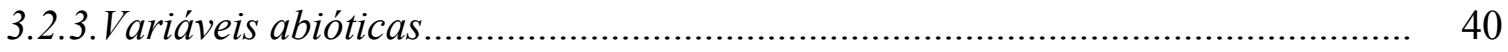

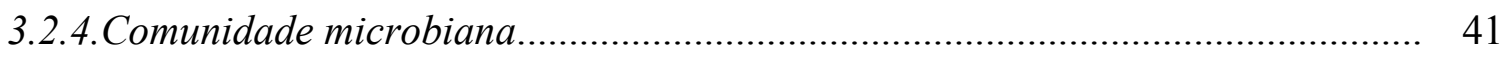

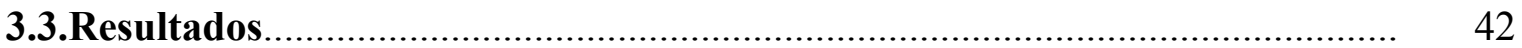

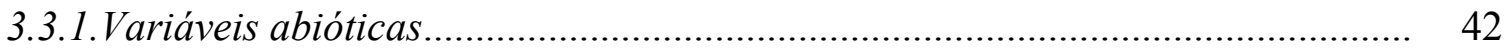

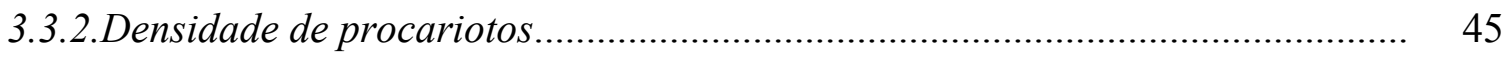

3.3.3.DGGE e diversidade bacteriana .................................................................... 48

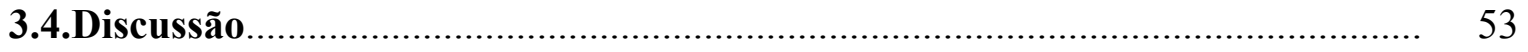

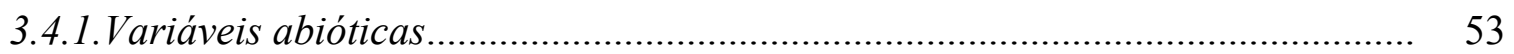

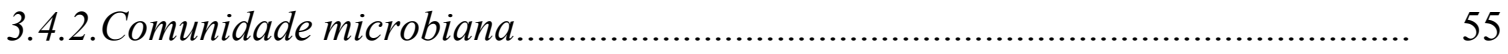

Capítulo 4: Resposta da comunidade microbiana do sedimento a eventos de ressuspensão em sedimentos marinhos costeiros

4.1.Introdução

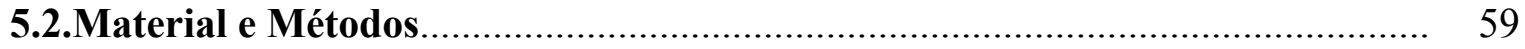

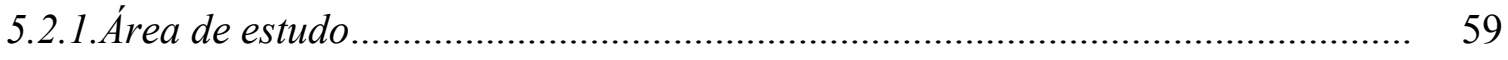


5.2.2.Amostragem e montagem experimental............................................................ 60

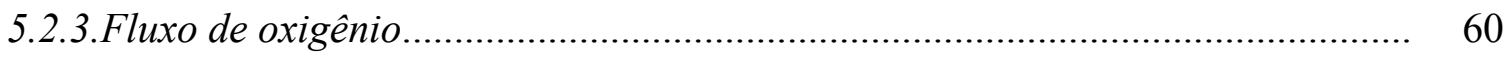

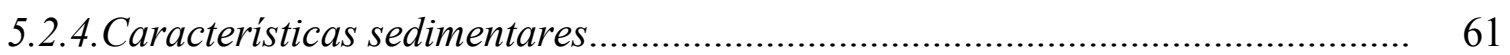

5.2.5.Densidade de procariotos.................................................................................. 61

5.2.6. Extração do DNA, PCR e DGGE..................................................................... 62

5.2.7.Sequenciamento das bandas de DGGE e análise filogenética.......................... 62

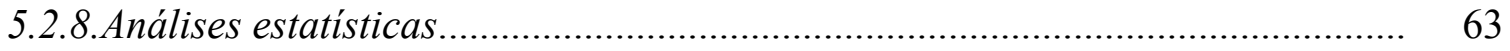

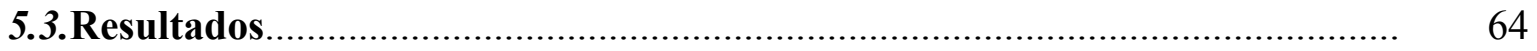

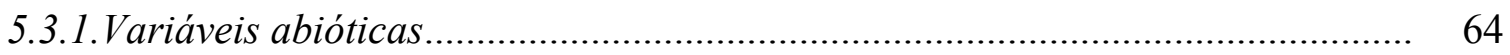

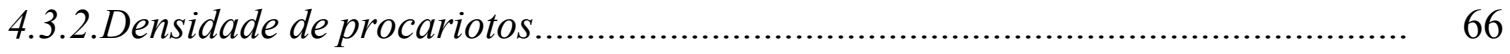

4.3.3.DGGE e diversidade bacteriana .................................................................... 66

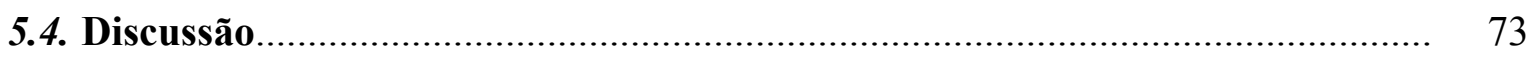

5.4.1.Efeito da ressuspensão no consumo de oxigênio e parâmetros sedimentares..... 73

5.4.2.Efeito da ressuspensão na comunidade microbiana do sedimento..................... 74

Capítulo 5: Influência da ressuspensão na distribuição vertical dos micro-organismos de sedimentos marinhos

5.1.Introdução................................................................................................ 78

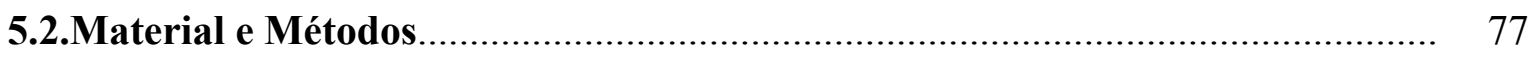

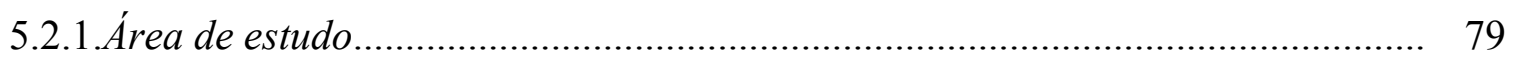

5.2.2.Amostragem e montagem experimental...................................................... 80

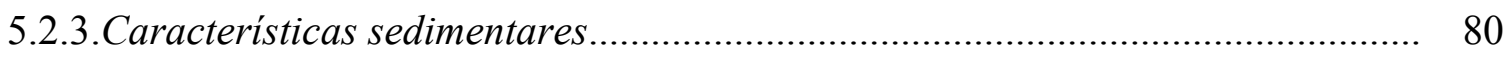

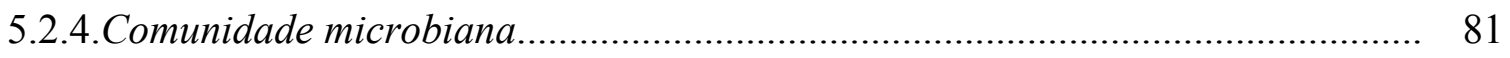

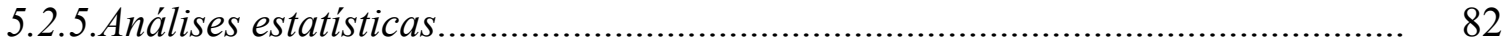

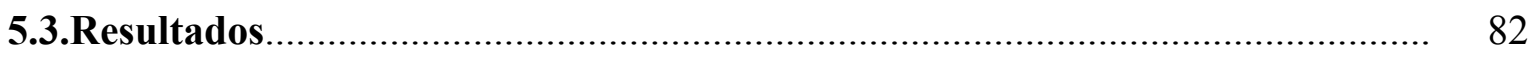

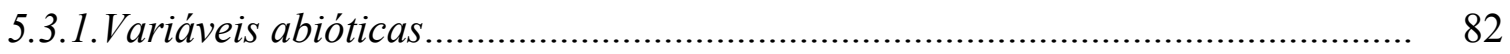




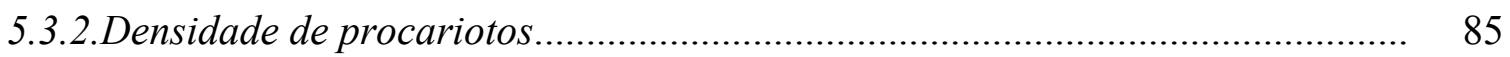

5.3.3.DGGE e diversidade bacteriana .................................................................. 87

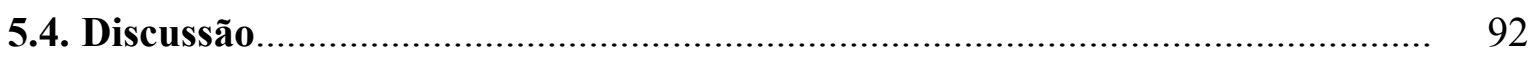

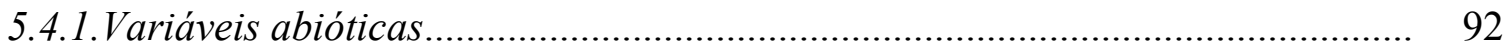

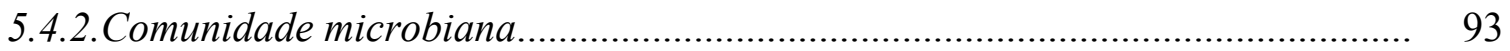

Capitulo 6: Diversidade bacteriana de sedimentos marinhos costeiros acessado através de bibliotecas genômicas.

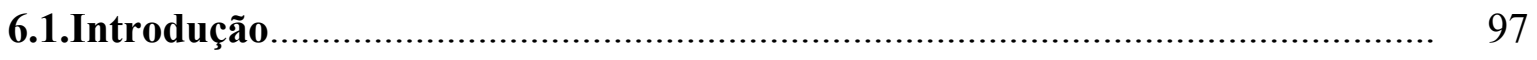

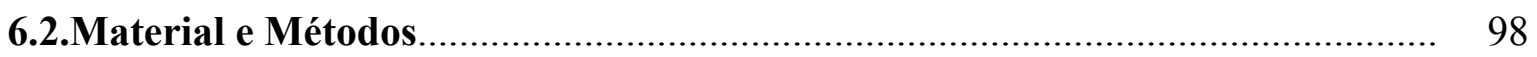

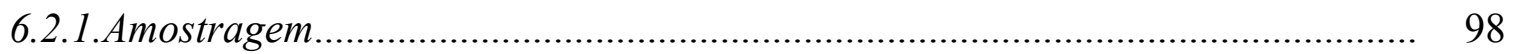

6.2.2.Extração, PCR e construção das bibliotecas genômicas................................... 98

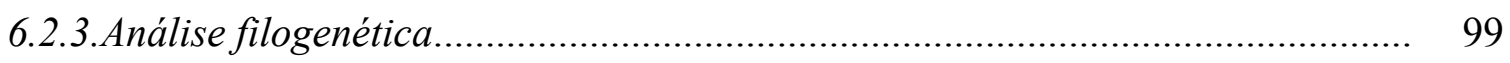

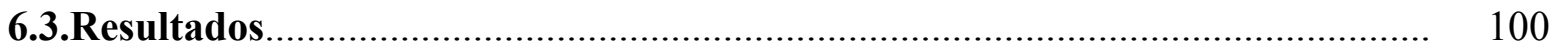

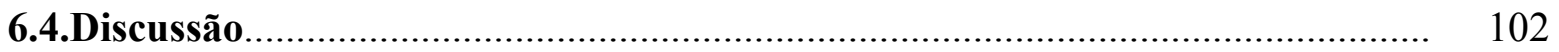

Capítulo 7: Considerações finais........................................................ 107

7.1. Efeito da matéria orgânica particulada derivada do plâncton na comunidade

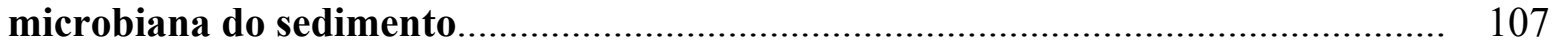

7.2. Efeito de eventos de ressuspensão na comunidade microbiana do sedimento.. 109

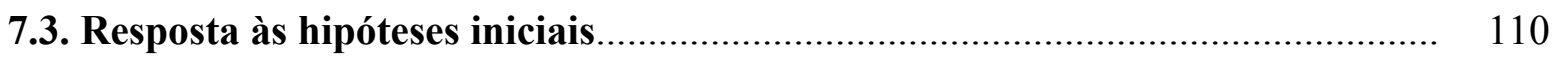

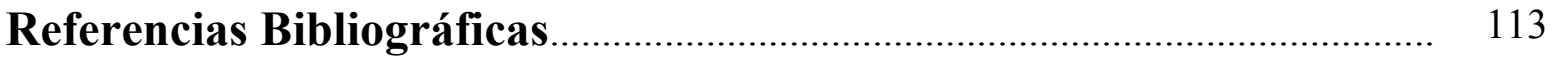

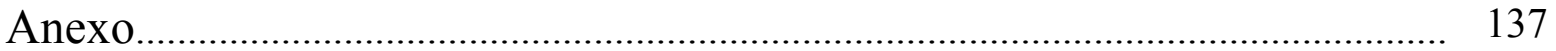




\section{ÍNDICE DE TABELAS}

Tabela 2.1: Análise estatística ANOVA dos valores de clorofila-a e feopigmentos na camada superficial durante o tempo do experimento.

Tabela 2.2: Análise estatística ANOVA dos valores de densidade total e de células vivas na camada superficial durante o tempo do experimento

Tabela 2.3: Afiliação filogenética dos genótipos detectados na primeira camada sedimentar das amostras experimentais sequenciadas a partir das bandas de DGGE.....

Tabela 4.1: Análise de Variância (ANOVA) dos valores de densidade total e de células vivas na camada superficial durante o período do experimento.

Tabela 4.2: Afiliação filogenética dos genótipos detectados na primeira camada sedimentar das amostras experimentais sequenciadas a partir das bandas de DGGE.....

Afiliação filogenética dos genótipos detectados a partir das bibliotecas genômicas utilizando BLAST (GenBank). 


\section{ÍNDICE DE FIGURAS}

Figura 1.1. Mapa da área de estudo mostrando as estações de coleta (Ponto 1: experimento 1 e Ponto 2: experimento 2), na costa de Ubatuba (SP).

Figura 1.2. a. Mini-multicorer utilizado durante as primeiras coletas do presente projeto; b. Sedimento sendo peneirado em malha de $1 \mathrm{~mm}$ após coleta; c. Bateria de testemunhos sendo remontados no LIPO.

Figura 1.3. Experimentos sendo mantidos em sala com temperatura controlada a $19^{\circ} \mathrm{C}$ no LIPO, na Base Norte do IOUSP em Ubatuba-SP. Testemunhos mantidos por um sistema de circulação interna para garantir a oxigenação do sedimento.

Figura 1.4. a. Bomba colocada no interior dos testemunhos para a realização da ressuspensão do sedimento. b. Dezoito testemunhos fechados durante a realização do experimento de ressuspensão do sedimento.

Figura 1.5. Incubação dos testemunhos mostrando o sistema de circulação magnética interna para cada tubo

Figura 2.1: Fluxo de oxigênio $\left(\mathrm{mm} \mathrm{m}^{-2} \mathrm{~d}^{-1}\right)$ através da interface sedimento-água e (média \pm erro padrão) dentro do tempo experimental. (* $\mathrm{p}<0.05$, ANOVA, Tukey)

Figura 2.2: Valores de (a) material orgânico total (MOT) e (b) carbono orgânico total (TOC) na primeira camada $(0-1 \mathrm{~cm})$ (média \pm erro padrão) dentro do tempo experimental (horas). (* $\mathrm{p}<0.05$, ANOVA, Tukey).

Figura 2.3: Distribuição dos fitopigmentos (média \pm erro padrão) na primeira camada sedimentar $(0-1 \mathrm{~cm})$ dentro do tempo experimental (horas). (* $\mathrm{p}<0.05$, ANOVA, Tukey). (a) clorofila-a (b) feopigmentos

Figura 2.4: Densidade de procariotos (a) e densidade de células vivas (b) (média \pm erro padrão) na camada superficial $(0-1 \mathrm{~cm})$ do sedimento dentro do tempo experimental. (* $\mathrm{p}<0.05$, ANOVA, Tukey)

Figure 2.5: Porcentagem de células vivas e mortas pela coloração de Live/Dead na primeira camada $(0-1 \mathrm{~cm})$ do sedimento no tempo amostrado (horas)

Figura 2.6: Análise de redundância (RDA) observando a influência das variáveis abióticas $(n=19,5$ variáveis) na densidade de procariotos $(n=19,2$ variáveis). DT. Densidade total; DV. Densidade vivas; Chl. Clorofila; Feo. Feopigmentos; T. Tetrasselmis; P. Phaeodactylum; C. controle.

Figura 2.7: Estrutura da comunidade bacteriana representada em um gel de DGGE (gradiente 35-60\%) do gene 16S (338f-GC-518r) do DNA extraído da primeira camada do sedimento. Letras indicam as bandas cortadas e sequenciadas.

Figura 2.8: Número de bandas identificadas no gel de DGGE da comunidade bacteriana.

Figura 2.9: Análise de agrupamento do padrão de bandas de DGGE das bactérias sedimentares usando a análise UPGMA. Matrix de similaridade calculada usando DICE 
Figura 2.10: Análise de correspondência canônica (CCA) usando os perfis de PCRDGGE das amostras do sedimento e as variáveis sedimentares medidas (clorofila-a, feopigmentos, MOT, COT, densidade total de procariotos e densidade de células vivas). a. CCA mostrando apenas as variáveis significativas de acordo com o teste de Monte Carlo $(p<0.05)$ b. CCA mostrando a influência de todas as variáveis..

Figura 3.1: Perfis de clorofila-a ( $\mu \mathrm{g} \mathrm{g}^{-1}$ sedimento seco) dos primeiros $20 \mathrm{~cm}$ do sedimento, média \pm erro-padrão, durante os períodos amostrados.

Figura 3.2: Perfis de feopigmentos ( $\mu \mathrm{g} \mathrm{g}^{-1}$ sedimento seco) dos primeiros $20 \mathrm{~cm}$ do sedimento, média \pm erro-padrão, durante os períodos amostrados.

Figura 3.3: Perfis de MOT (\%) dos primeiros $20 \mathrm{~cm}$ do sedimento, média \pm erropadrão, durante os períodos amostrados.

Figura 3.4: Perfis de densidade total de procariotos (células $\mathrm{ml}^{-1}$ ) em quatro camadas da coluna sedimentar $(0-1,1-2,4-5$ e 14-17 cm), média \pm erro padrão, nos tempos amostrados.

Figura 3.5: Perfis de densidade de procariotos vivos (células $\mathrm{ml}^{-1}$ ) em quatro camadas da coluna sedimentar $(0-1,1-2,4-5$ e $14-17 \mathrm{~cm})$, média \pm erro padrão, nos tempos amostrados.

Figura 3.6: Análise de Componentes Principais (PCA) das variáveis encontradas durante o período experimental. $\mathrm{T}=$ tratamento com Tetrasselmis $; \mathrm{P}=$ tratamento com Phaeodactylum $; \mathrm{C}=$ controle $; \mathrm{Chl}=$ clorofila-a; $\mathrm{Feo}=$ feopigmentos $; \mathrm{DT}=$ Densidade total de procariotos; $\mathrm{DV}=$ Densidade de procariotos vivos

Figura 3.7: Número de bandas identificadas no gel de DGGE da comunidade bacteriana nos estratos do sedimento.

Figura 3.8: Análise de agrupamento do padrão de bandas de DGGE das bactérias sedimentares da camada 1-2 $\mathrm{cm}$ usando a análise UPGMA. Matriz de similaridade calculada usando DICE

Figura 3.9: Análise de agrupamento do padrão de bandas de DGGE das bactérias sedimentares da camada 4-5 cm usando a análise UPGMA. Matriz de similaridade calculada usando DICE

Figura 3.10: Análise de agrupamento do padrão de bandas de DGGE das bactérias sedimentares da camada 14-17 cm usando a análise UPGMA. Matriz de similaridade calculada usando DICE.

Figura 3.11: Análise de agrupamento da estrutura vertical do padrão de bandas de DGGE das bactérias sedimentares usando a análise UPGMA. Matriz de similaridade calculada usando DICE

Figura 3.12: Análise de correspondência canônica (CCA) usando os perfis de PCRDGGE das amostras do sedimento e as variáveis sedimentares medidas. a. 1-2 cm; b. 4-5 cm; c. 14-17 cm; d. distribuição verical. * variável com influência significativa na variação das bandas de DGGE, segundo teste de Monte Carlo (9999 permutações).

Figura 4.1: Fluxo de oxigênio $\left(\mathrm{mM} \mathrm{m}^{-2} \mathrm{~d}^{-1}\right)$ através da interface sedimento-água (média \pm erro padrão) ao longo do tempo experimental. ( $* \mathrm{p}<0.05$, ANOVA, Tukey)... 
Figura 4.2: Valores de (a) material orgânico total (MOT) e (b) carbono orgânico total (COT) na primeira camada $(0-1 \mathrm{~cm})$ (média \pm erro padrão) ao longo do experimento (horas) $(* \mathrm{p}<0.05$, ANOVA, Tukey).

Figura 4.3: Distribuição dos fitopigmentos (média \pm erro padrão) na primeira camada sedimentar $(0-1 \mathrm{~cm})$ ao longo do experimento (horas) $(* \mathrm{p}<0.05$, ANOVA, Tukey). (a) clorofila-a; (b) feopigmentos.

Figura 4.4: Análise de Componentes Principais (PCA) das variáveis abióticas encontradas durante $\mathrm{o}$ período experimental. $\mathrm{R}=$ tratamento com ressuspensão; $\mathrm{C}=$ controle; $\mathrm{Chl}=$ clorofila-a; $\mathrm{Feo}=$ feopigmentos; $\mathrm{Ox}=$ fluxo de oxigênio......

Figura 4.5: Densidade de procariotos (a) e densidade de células vivas (b) (média \pm erro padrão) na camada superficial $(0-1 \mathrm{~cm})$ do sedimento ao longo do experimento. (* p $<0,05$, ANOVA, Tukey).

Figure 4.6: Análise de redundância (RDA) observando a influência das variáveis abióticas ( $\mathrm{n}=19,5$ variáveis) na densidade de procariotos ( $\mathrm{n}=19,2$ variáveis).

Figura 4.7: Estrutura da comunidade bacteriana representada em um gel de DGGE (25$70 \%$ ) do gene $16 \mathrm{~S}$ do rRNA (338f-GC e 518r ) extraído da primeira camada do sedimento. Letras indicam as bandas cortadas e sequenciadas. $\mathrm{R}=$ ressuspensão, $\mathrm{C}=$ controle

Figura 4.8: Número de bandas identificadas no gel de DGGE da comunidade bacteriana.

Figura 4.9: Análise de agrupamento do padrão de bandas de DGGE das bactérias sedimentares usando a análise UPGMA. Matriz de similaridade calculada usando DICE

Figura 4.10: Análise de correspondência canônica (CCA) usando os perfis de PCRDGGE das amostras do sedimento e as variáveis sedimentares medidas a. CCA mostrando apenas as variáveis significativas de acordo com o teste de Monte Carlo $(\mathrm{p}<0.05)$ b. CCA mostrando a influência de todas as variáveis

Figura 5.1: Perfis de clorofila-a $\left(\mu \mathrm{g} \mathrm{g}^{-1}\right)$ dos primeiros $20 \mathrm{~cm}$ do sedimento, média \pm erro-padrão, durante os períodos amostrados.

Figura 5.2: Perfis de feopigmentos ( $\mu \mathrm{g} \mathrm{g}^{-1}$ sedimento seco) dos primeiros $20 \mathrm{~cm}$ do sedimento, média \pm erro-padrão, durante os períodos amostrados.

Figura 5.3: Perfis de matéria orgânica total (MOT \%) dos primeiros $20 \mathrm{~cm}$ do sedimento, média \pm erro-padrão, durante os períodos amostrados

Figura 5.4: Perfis de densidade total de procariotos (células $\mathrm{ml}^{-1}$ ) em quatro camadas da coluna sedimentar (0-1, 1-2, 4-5 e 14-17 cm), média \pm erro padrão, nos tempos amostrados.

Figura 5.5: Perfis de densidade de procariotos vivos (células $\mathrm{ml}^{-1}$ ) em quatro camadas da coluna sedimentar (0-1, 1-2, 4-5 e 14-17 cm), média \pm erro padrão, nos tempos amostrados.

Figura 5.6: Análise de redundância (RDA) observando a influência das variáveis abióticas ( $\mathrm{n}=95,4$ variáveis) na densidade de procariotos ( $\mathrm{n}=95,2$ variáveis). * variável com influência significativa segundo teste de Monte Carlo (9999 permutações). Res. Ressuspensão, Chl. Clorofila-a, Feo. Feopigmentos, DT. 
Densidade total de procariotos, DV. Densidade de procariotos vivos, C. controle, R. tratamento com ressuspensão.

Figura 5.7: Número de OTUs (bandas) identificadas no gel de DGGE da comunidade bacteriana nos estratos do sedimento.

Figura 5.8: Análise de agrupamento do padrão de bandas de DGGE das bactérias sedimentares da camada 1-2 cm usando a análise UPGMA. Matriz de similaridade calculada usando DICE

Figura 5.9: Análise de agrupamento do padrão de bandas de DGGE das bactérias sedimentares da camada 4-5 cm usando a análise UPGMA. Matriz de similaridade calculada usando DICE

Figura 5.10: Análise de agrupamento do padrão de bandas de DGGE das bactérias sedimentares da camada 14-17 cm usando a análise UPGMA. Matriz de similaridade calculada usando DICE.

Figura 5.11: Análise de agrupamento da estrutura vertical do padrão de bandas de DGGE das bactérias sedimentares usando a análise UPGMA. Matriz de similaridade calculada usando DICE.

Figura 5.12: Análise de correspondência canônica (CCA) usando os perfis de PCRDGGE das amostras do sedimento e as variáveis sedimentares medidas. a. 1-2 cm; b. 4-5 cm; c. 14-17 cm; d. distribuição verical. * variável com influência significativa na variação das bandas de DGGE, segundo teste de Monte Carlo (9999 permutações)........

Figura 6.1: Abundância relativa das sequencias pertencentes às diferentes linhagens filogenéticas dentro das sete amostras de sedimento. T. Tetrasselmis; P. Phaeodactylum; R. Ressuspensão; CR. Controle do experimento de ressuspensão. 


\section{AGRADECIMENTOS}

Agradeço ao Instituto Oceanográfico da Universidade de São Paulo (IOUSP) e ao Programa de Pós-graduação em Oceanografia Biológica por ter propiciado a realização deste estudo. À Fundação de Amparo a Pesquisa do Estado de São Paulo (FAPESP) pela bolsa de doutorado disponibilizada e pelo financiamento do projeto de pesquisa do qual esse trabalho faz parte.

Meus sinceros agradecimentos ao Prof. Dr. Paulo Tukio Gomes Sumida, pela orientação e pelos ensinamentos nestes muitos anos de trabalho, por ter me iniciado no mundo da oceanografia e pela paciência e amizade demonstrada nestes anos. Muito abrigada por todas as puxadas de orelha e pela alegria demonstrada em todas as horas, e principalmente por ter acreditado em mim e no meu trabalho, pelas muitas oportunidades e por ter sido um ótimo orientador e amigo. Por ter me apoiado nesse projeto e por sempre estar aberto a novas ideias, sempre acreditando que tudo que queremos fazer é possivel, por confiar em tudo que faço. Por todas as correçoes e ensinamentos, aprendi muito nesses anos, não só de trabalho, mas também de convivência e amizade. Adoro trabathar com vocêe espero que continuemos trabalhando juntos por muitos mais anos. MVITO OBRRIGADA POR TUDO!!!!

Agradeço muito a toda minha familia. Aos meus pais Paulo e Lote, que são as pessoas mais importantes da minha vida. Obrigada pela atenção, apoio e por acreditarem e terem tanto orgulho do que eu faço. Eu amo muito vocês e sem o seu apoio eu nunca teria conseguido. Minhas queridas irmãs Alessandra e Fernanda por estarem sempre lá quando eu precisei e por me apoiar em tudo. A minha Vovoca valeu por todos os momentos que passamos juntas. Amo muito todos vocês.

Agradeço demais ao meu querido companheiro de todas as horas Eduardo. Du você foi muito importante para que tudo isso fosse possivel, muito obriga pela compreensão, paciência e alegria. Você sabe que eu te amo muito, você é meu melhor amigo e há muitos anos você me apóia em tudo o que eu faço e se desvira para não deixar eu me abalar. Muito obrigada por ter acreditado no meu sonho e por me apoiar em todas as horas, até nas mais dificeis. Obrigada pelo seu carinho e amor e por estar sempre ao meu lado, mesmo de Longe, saudades imensas de você aqui comigo. Te amo muito!!!!

A minha querida amiga de sempre Adriana, que apesar de não entender como eu ainda estou "estudando" sempre me apoiou em tudo. Valeu pela sua amizade sempre presente, prometo que vou aparecer mais, te amo muito, sua amizade é muito importante para mim. A minha querida prima Kelly que voltou a fazer parte da minha vida, te amo muito, muitas saudades de você e de nossas conversas divertidas. Aos meus amigos distantes Glé, Li, Joel, Serginho, André e Alex, adoro vocês e espero que a gente se encontre mais nos próximos anos estou com saudades, vocês foram muito importantes na minha formação muito obrigada pelo apoio e compreensão. À minha grande amiga 
dinamarquesa Cintia pela amizade e pelos seus ensinamentos. Cabę̧a valeu por toda a ajuda que você me deu todos esses anos. Por escrever esse projeto comigo, apesar de não ter participado da execução você foi uma das pensantes do projeto, então ele é um pouco seu também. Te adoro, e morro de saudades !!!!!!!!

A minha querida companheira de projeto Aninha, valeu por todas as horas de trabalho e diversão. Pelo trabalho árduo nas coletas e análises mil, por ser essa grande amiga e companheira de todas as horas. Pelos vários meses de confinamento juntas tanto em U6atuba quanto nos embarques, não é fácil conviver com alguém tanto tempo sem dar problemas, e acredito que conseguimos isso, $e$ espero que continuemos a trabalhar juntas, em time que está ganhando não se mexe, né. Te adoro muito!!!!!!!

A todos os amigos do laboratório de Dinâmica Bêntica que tornam os dias de trabalho muito prazerosos. Be, minha parceira de mergutho, por todos os momentos maravilhosos de trabatho e diversão, valeu pela alegria e pelos esforcos, sempre disposta a ajudar em tudo, pelo auxilio nas coletas e madrugadas trabalhando. Você é uma pessoa especial, te adoro muito. Ka, valeu por tudo, pela amizade e trabalho, sempre disposta a ajudar em tudo que for possivel, e pelos bolos no lab, te adoro. Maria, pela ajuda nas coletas e nos meus muitos pedidos em V6atuba. Tutu, por toda a ajuda em todas as coletas e confecção dos experimentos, pela amizade e alegria, pelas baladas e conversas, muito obrigada por tudo. Mauzinho, não sei nem como começar a te agradecer por tudo que você me ajudou, muito obrigada pela ajuda nas coletas e principalmente pela amizade, você é uma pessoa maravilhosa, valeu pela companhia em viagens e trabalho, você é a pessoa mais maravilhosa que já conheci, sua amizade é muito importante para mim, valeu por estar sempre disposto a ajudar em tudo. Te amo muito meu amigo. Marcos valeu pela ajuda nas coletas e pela alegria no laboratório. Obrigado a todos do Laboratório pela ajuda e amizade, Miguel, Renato, Pacu, Elisa, Olivia e Felipe.

Aos amigos de outros laboratórios e funcionários. Cainha, valeu por tudo, pela ajuda nas coletas, pela amizade e alegria nas horas de almoço e café. Pelos encontros sempre divertidos na sua casa, te adoro muito amiga. Déa, saudades mil, você faz muita falta aqui no lab, valeu pela alegria e 6om humor, muito obrigada pela sua amizade, te adoro muito. San, obrigada por tudo, pela ajuda no trabalho, e por sempre estar disposta a ouvir minhas lamentaçôes, pela amizade e alegria, você é a alegria do IO, te adoro. Caulene, muito obrigada pela amizade e pelas muitas horas de lazer juntas, te adoro muito amiga. A todos os amigos de IO, Jasão e Hélio pela ajuda na coleta mais complicada do meu trabalho, por nunca perder a piada e ajuda nos mergulhos. Mi, Ju e Pedro valeu pela amizade e conversas. Frango, pelas muitas conversas, muito obrigada. Gui, valeu pela ajuda na coleta e pela força de sempre e amizade sempre presente, te adoro muito.

A todos que ficaram comigo algum tempo em V6atuba, Naira, Carol, Pri, Zezé, Carol valeu pela companhia e alegria. Fabião valeu pela ajuda e amizade, se não fosse você em Vbatuba eu 
estava perdida, muito obrigada por tudo. Cássia e Newton, nunca imaginei que ia ficar tão amiga de vocês, acredito que construímos uma amizade muito sincera e duradoura, muito obrigada pela companhia em Ubatuba, se não fosse vocês minha estadia lá com certeza seria muito mais difícil, valeu por toda a ajuda no laboratório e principalmente pelos CHUR囚ASCOS!!!! Ainda me devem um na casa nova!!! Adoro vocês demais. Caio, muito obriga pela alegria e companhia, pela ajuda em tudo que precisávamos em V6atuba, sem você aquela base é uma tristeza, valeu pelas piadas e risadas, por tudo que você fez por mim, saudades mil de você, te adoro muito. Bicão, muito obrigada pela amizade e companhia em Sampa e U6atuba, foi muito divertido ter você lá. Fabiano, obrigada pela companhia em Ubatuba e pelas idas na praia e churrascos, valeu.

Aos amigos Thais e Cabelo, valeu pelas viagens e companfia certa na Bio, pela alegria e amizade, adoro muito vocês. Tatá muito obrigada por tudo amiga, por ceder sempre a sua casa para mim e por ser essa pessoa maravilhosa, te adoro muito.

A Prof. Vivian por ter disponibilizado o seu laboratório tão prontamente para minhas análises, por toda a ajuda e amizade, muito obrigada. Aos novos amigos do Laboratório de Microbiologia, Dani, Fabi, Adriana, Simone, Cris, Ana, Rubens e Rosa, obrigada por toda ajuda, por sempre tirarem minhas dúvidas por mais bobas que fossem e por me aguentarem usando sempre os equipamentos, valeu por tudo. Dieguito, como começar a te agradecer, muito obrigada por toda a ajuda que você me deu, por me ensinar e por passar comigo pelo drama dos milhares de DGGEs e depois das temidas bibliotecas. Obrigada pela paciência em me ensinar tudo de análise de Gactéria e pela incansável ajuda. Obriga principalmente pela amizade, festas e muito mais, te adoro muito!!!!!

$\mathcal{A}$ todos os funcionários do $\mathscr{D} O B$ que me agüentaram nestes anos. Valter por sempre estar disposto a ajudar em tudo, pelo 6om humor e amizade, muito obrigada. D. Cida e Marlene que com muita boa vontade me ajudaram em tudo que precisei muito abrigada pela atenção. Cidinha e Ruth, não tenho nem palavras para agradecer a vocês por terem lavado centenas de potes e frascos sempre com tanta boa vontade, sem vocês meu trabalho seria dobrado muito obrigada pela atenção e ajuda imprescindivel Todo o pessoal da biblioteca agradeço pela atenção e pelas ajudas na busca por artigos e livros. Silvana, Ana Paula e Leticia por não se importarem em sempre ajudar nas inúmeras dúvidas e atrasos, sem perder o 6om humor, muito obrigada por tudo, vocês são realmente demais. Ao pessoal do salão azule da oficina por sempre ajudarem em tudo, muito obrigada. Tomás, não sei nem como te agradecer por toda a ajuda não só nas coletas, mas em tudo que precisei, você é uma pessoa maravilhosa e um trabalhador incansável, muito obrigada por toda a ajuda.

A todo pessoal da base de VGatuba, muito obrigada por tudo, vocês são pessoas maravilhosas e ter ficado tanto tempo em Vbatuba foi uma diversão, obrigada por sempre arrumarem um jeitinho pra tudo e sempre ajudarem em tudo que precisei. D. Cida, Bete e Vânia muito obrigada pela deliciosa comida e pelo clima sempre alegre e descontraído de vocês. Aos tripulantes do B/Pq Véliger II, Oziel, 
Daíco, Manoele Adriano, muito obrigada pela ajuda nas coletas malucas, coletar mais de 100 corers em um dia é pra quem pode, não para quem quer, e nunca teria conseguido sem a ajuda de vocês, obrigada pela boa vontade, pelos ensinamentos e por tornar toda saída de barco muito divertida.

Aos professores do IO e de outros institutos nacionais e internacionais que de alguma forma contribuiram para minha formação acadêmica e pessoal através de disciplinas, conversas, e cursos, muito obrigado pela atenção de vocês.

Agradeço também a todas as pessoas amigas que acabei deixando de fora por simples descuido, (podem me cobrar depois) e que de alguma forma fizeram parte desta fase da minha vida profissional e pessoal.

MUITO OBRIGA А TODOS!!!!!!!!!!!!!! 


\section{RESUMO}

O presente estudo visou investigar os efeitos da ressuspensão do sedimento e enriquecimento orgânico por diferentes microalgas na estrutura das comunidades microbianas do sedimento. Para tanto dois experimentos laboratoriais separados foram realizados (Nov-Dez/2009 e Abr-Maio/2011) com o intuito de simular as condições de ressuspensão e pulsos de produtividade primária observadas em campo e assim observar como a comunidade microbiana do sedimento é influenciada por esses eventos. Ambos os experimentos foram mantidos por um total de 30 dias após o tratamento, durante os quais amostras para análises sedimentares, densidade de procariotos e composição da comunidade bacteriana foram tomadas em seis períodos diferentes. A camada superficial do sedimento foi estudada mais detalhadamente e mostrou que tanto a chegada de material algal quanto a ressuspensão são responsáveis por mudanças significativas na densidade, metabolismo e composição da comunidade bacteriana do sedimento. Ainda, a chegada de diferentes tipos de algas ao sedimento (fitoflagelados e diatomáceas) levou a diferentes repostas tanto na densidade quanto na diversidade dos micro-organismos sedimentares. A estrutura vertical dos micro-organismos na coluna sedimentar também foi estudada. A chegada de material algal no sedimento não levou a grandes mudanças na estrutura da comunidade mais profundas da coluna sedimentar. A estabilidade criada pelo ambiente experimental parece ter levado a um aumento tanto da densidade quanto da diversidade microbiana na camada intermediária do sedimento, em ambos os tratamentos e no controle. Já a ressuspensão parece influenciar de forma mais efetiva a distribuição dos micro-organismos na coluna sedimentar, devido a mistura da coluna sedimentar e mudanças nas condições redox das camadas sedimentares. Concluindo, tanto a chegada de alimento no sedimento, como eventos de ressuspensão são responsáveis por mudanças significativas na comunidade microbiana dos sedimentos costeiros.

Palavras-chaves: enriquecimento orgânico; ressuspensão sedimentar; sedimentos costeiros; micro-organismos marinhos; DGGE; comunidade bacteriana 


\section{ABSTRACT}

The present study aimed to investigate the effects of sediment resuspension and organic enrichment by different microalgae on the sedimentary microbial community structure. We run two separate laboratory experiments (Nov-Dec/2009 and Apr-May/2011) to simulate resuspension conditions and pulses of primary productivity observed in the field, and analyze how these events affect the microbial community. Both experiments were maintained for a total of 30 days following treatment when samples were taken for sedimentary analysis, prokaryotic density and bacterial community analyses at six different sampling times. The sediment surface layer was studied in more detail, and showed that both the input of algal material and resuspension are responsible for significant changes in density, metabolism and bacterial community composition. Also, the arrival of different types of algae to the sediment (phytoflagellates and diatoms) led to different responses in both density and diversity of sedimentary microorganisms. The vertical structure of microorganisms in the sediment column was also studied. The arrival of algal material in the sediment did not show important changes in community structure of the deeper sedimentary layers. The stability created by the experimental environment seems to increase both the density and diversity of microbes in the middle layer of sediment in both treatments and control. On the other hand resuspension seems to influence more effectively the distribution of microorganisms in the sedimentary column due to sediment mixing and changes in redox conditions of different layers. In conclusion, both the arrival of food on the sediment and resuspension events is responsible for important changes in the coastal sediment microbial communities.

Key-words: organic enrichment; sedimentary resuspension; coastal sediments; marine microorganisms; DGGE; bacterial community 


\section{Capítulo 1: Introdução Geral}

\subsection{Introdução}

Grandes quantidades de matéria orgânica particulada (MOP) são depositadas nos sedimentos marinhos, o que estimula o aumento da degradação biogeoquímica mediada por micro-organismos. Esse fenômeno, conhecido como diagênese recente da MO (Henrichs, 1992), pode ser definido como a soma dos processos físicos, químicos e biológicos que alteram a quantidade e composição dos materiais orgânicos nos primeiros metros da coluna sedimentar (Henrichs, 1992; Canuel \& Martens, 1996). A MOP depositada no sedimento é decomposta principalmente pela ação dos microorganismos, produzindo gradientes complexos na coluna sedimentar (Findlay et al., 1990) e controlando o ciclo de importantes elementos químicos como carbono, nitrogênio e fósforo.

Os mecanismos de controle da degradação e preservação da matéria orgânica (MO) não são completamente conhecidos, porém sabe-se, que dependem de um grande número de fatores (Turnewitsch et al., 2007), incluindo valor nutricional, fontes e reatividade da MO (i.e. qualidade). Fatores ambientais como temperatura, concentração de aceptores de elétrons, intensidade da produção primária, taxa de sedimentação, tempo de exposição ao oxigênio, adsorção a superfícies minerais e bioturbação também são importantes (Henrichs, 1992; Hedges \& Keil, 1995; Kristensen, 2000; Wakeham \& Canuel, 2006).

Sistemas costeiros são locais de intensa produtividade, sedimentação, degradação e enterramento do carbono orgânico, muito embora representem apenas $11 \%$ da área total da superfície dos oceanos (Berner, 1980; Hedges \& Keil, 1995). A região costeira é responsável por cerca de $20 \%$ da produtividade primária e pela grande maioria do carbono enterrado no oceano (Duarte et al., 2004). Em média, 25-50\% da produtividade primária atinge os sedimentos em áreas costeiras, enquanto que este número decresce para apenas $1 \%$ em regiões de oceano profundo (Suess, 1976). A elevada produtividade fitoplanctônica decorrente da alta disponibilidade de nutrientes (de origem natural ou antrópica) acoplada às altas taxas de sedimentação e baixas profundidades, permite a preservação de uma larga porção do carbono orgânico nos depósitos sedimentares (Hedges \& Keil, 1995; Meyers, 1997; Wakeham et al., 1997). Deste modo, os processos de remineralização nestes locais têm importantes 
consequências no ciclo do carbono, sendo imprescindível o melhor entendimento dos mecanismos biogeoquímicos de degradação, bem como do papel das comunidades microbianas bênticas.

Bactérias e outros micro-organismos heterotróficos compreendem um importante componente nos ciclos biogeoquímicos de elementos essenciais, bem como no fluxo de energia em ecossistemas aquáticos (e.g. Azam et al., 1983). Microorganismos reagem rapidamente à sedimentação de fitoplâncton através de um aumento em sua biomassa, densidade e produtividade, as quais, normalmente, acompanham aumentos na clorofila sedimentar (Meyer-Reil, 1983; Danovaro et al., 1999; Pfannkuche et al., 2000; Shiah et al., 2000; Smith et al., 2002; Rusch et al., 2003). Contudo, possíveis mudanças na composição e diversidade de comunidades bacterianas bênticas em resposta a inputs de MO não são completamente conhecidas (Rink et al., 2007).

Recentemente, tem se tornado evidente que bactérias são organismos dominantes, tanto em termos de abundância relativa (densidade e biomassa) quanto em termos de contribuição para os processos no ecossistema (Fuhrman et al., 2006). Vários estudos com mesocosmos têm demonstrado que distintos componentes monoméricos e poliméricos do carbono orgânico dissolvido, seja via suprimento direto ou indução experimental de florescimentos de fitoplâncton, selecionam subcomunidades específicas ou populações de bacterioplâncton (Lebaron et al., 1999; Riemann et al., 2000; Abell \& Bowman, 2005). A composição específica da matéria orgânica de várias algas também parece ser um importante fator selecionando comunidades e populações de bactérias planctônicas distintas (Grossart, 1999; Schäfer et al., 2002; Grossart et al., 2005). O estudo e conhecimento da associação entre diferentes tipos de carbono orgânico particulado (ou diferentes organismos planctônicos) chegando ao sedimento e comunidades microbianas sedimentares necessitam de maiores investigações, já que as bactérias sedimentares são de grande importância para a reciclagem e decomposição da matéria orgânica.

Em bacias rasas e regiões costeiras, a ação de ondas é também um importante fator que controla a degradação da MO, afetando sua deposição e ressuspensão (Jönsson et al., 2005). A ressuspensão altera a estrutura das camadas sedimentares, promovendo a redistribuição de sedimentos e enriquecendo a coluna d' água com nutrientes particulados e dissolvidos (Wainright, 1990; Tengberg et al., 2003). Turbulências induzidas pelo vento controlam a produtividade em muitos ecossistemas de água rasa (Frechett et al., 1988; Hellström, 1991), principalmente através do enriquecimento de 
nutrientes provenientes do sedimento (Christiansen et al., 1997). Processos de ressuspensão injetam uma grande quantidade de MO sedimentar na coluna d' água, aumentando a exposição desse material a condições óxicas, com um consequente aumento na disponibilidade de nutrientes para o fitoplâncton e o microfitobentos (Wainright \& Hopkinson Jr., 1997). Além disso, ocorre uma mistura de nutrientes presentes na água intersticial, o que leva a um aumento de produtividade e atividade planctônica, e mudanças nos perfis de concentração de nutrientes orgânicos e inorgânicos presente na coluna sedimentar (Laima et al., 1998).

Em sedimentos permeáveis, onde a ação de ondas e marés é muito ativa, vários estudos vêm observando altas taxas de mineralização da matéria orgânica (Huettel \& Rush, 2000; Werner et al., 2006; Franke et al., 2006), principalmente devido ao aumento da disponibilidade de solutos, como o oxigênio, e carbono orgânico particulado para o sedimento, enquanto remove inibidores potenciais e produtos dos processos de mineralização, dessa forma aumentando a atividade microbiana (Huettel et al., 1998; Werner et al., 2006). O mesmo tem sido observado em estudos sobre efeitos de bioturbação, onde a macrofauna aumenta o metabolismo microbiano bêntico e a capacidade de decomposição da matéria orgânica através de seus efeitos no transporte de solutos e partículas (Aller, 2001; Kristensen \& Kostka, 2004). Aumentos na densidade, biomassa e atividade bacteriana após eventos de ressuspensão têm sido observados também em estudos laboratoriais (Cotner et al., 2000; Garstecki \& Wickhan, 2001; Fiordelmondo et al., 2003; Fiordelmondo \& Pusceddu, 2004). Contudo, estudos sobre mudanças na estrutura da comunidade microbiana bêntica como resultado de forçantes ambientais, tais como ressuspensão e aumento do fluxo de biomassa fitoplanctônica ainda são incipientes (Watling et al., 2001).

A região costeira de Ubatuba, no litoral norte do Estado de São Paulo, é caracterizada por apresentar intensa incidência de frentes frias entre os meses de março e novembro (Mahiques et al., 1998). Estes eventos promovem a ressuspensão dos sedimentos, disponibilizando materiais orgânicos e nutrientes para a coluna de água (Gaeta et al., 1999). Dentre os efeitos no ecossistema, destacam-se mudanças na produtividade primária (Gaeta et al., 1999), composição fitoplanctônica (Aidar et al., 1993; Gaeta et al., 1999), reatividade e quantidade da MO sedimentar (Yoshinaga, 2006), além de afetar as comunidades microbianas bênticas locais (Quintana, 2004; Moraes, 2007). Em experimentos laboratoriais, a ressuspensão de sedimentos é, reconhecidamente, um fator que exerce uma influência significativa nos processos 
biogeoquímicos, podendo aumentar até cinco vezes a remineralização nas primeiras 24 h após o distúrbio físico (Ståhlberg et al., 2006).

O presente estudo visou investigar os efeitos da ressuspensão e enriquecimento orgânico por diferentes microalgas nos processos diagenéticos e na estrutura das comunidades microbianas do sedimento. Para tanto, experimentos laboratoriais foram realizados com o intuito de simular as condições de ressuspensão e pulsos de produtividade primária observadas em campo. $\mathrm{O}$ estudo está inserido no projeto de pesquisa denominado Estudo Experimental de Processos Biogeoquímicos na Interface Água-sedimento Mediados por Micro-organismos Marinhos (EXPIAMM) que visou uma abordagem quali- e quantitativa dos processos ocorrendo na interface águasedimento, através da estimação dos fluxos de nutrientes e material orgânico partindo do e chegando ao sedimento marinho. Através de medidas do metabolismo bêntico, ou seja, dos fluxos de oxigênio e $\mathrm{CO}_{2}$ dos sedimentos incubados em laboratório, foi possível verificar se a degradação da MO é estimulada, relacionando isso ao aumento dos micro-organismos no sedimento e assim inferir os principais fatores envolvidos nesses processo. Com esses estudos foram testadas as seguintes hipóteses:

i) A chegada de matéria orgânica particulada fresca no sedimento (produção fitoplanctônica) estimula a comunidade microbiana sedimentar;

ii) A introdução de diferentes organismos fitoplanctônicos, e.g. diatomáceas e fitoflagelados, leva a diferentes respostas da comunidade microbiana do sedimento, tanto no tempo quanto na abundância específica das espécies;

iii) A ressuspensão do sedimento estimula o crescimento e metabolismo da comunidade microbiana do sedimento;

iv) A estrutura da comunidade microbiana sedimentar é modificada após eventos de ressuspensão;

v) As mudanças da estrutura da comunidade microbiana nos perfis da coluna sedimentar serão diferentes entre os dois experimentos realizados (enriquecimento algal X ressuspensão); 


\subsection{Detalhamento da área de estudo e justificativa da proposta}

O ponto escolhido localiza-se na Plataforma Continental Sudeste Brasileira PCSE na costa de Ubatuba, litoral norte do Estado de São Paulo, com profundidade em torno de 40 m (Figura 1.1). Devido a problemas operacionais, dois pontos diferentes com distância em torno de $5 \mathrm{~km}$ entre si, foram amostrados para os dois experimentos.

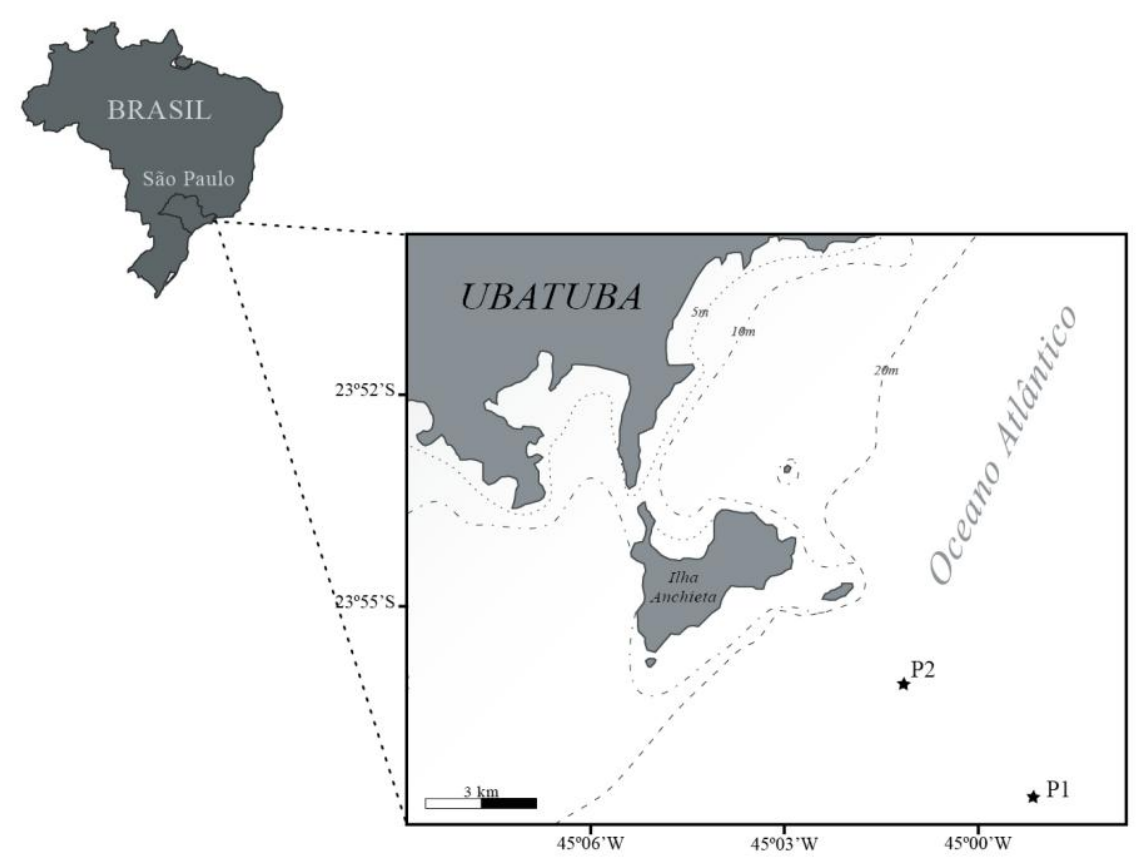

Figura 1.1. Mapa da área de estudo mostrando as estações de coleta (Ponto 1: experimento 1 e Ponto 2: experimento 2), na costa de Ubatuba (SP).

A região possui um regime oceanográfico de transição entre águas costeiras e de plataforma continental, sendo caracterizada pelo domínio de três diferentes massas de água: Água Central do Atlântico Sul (ACAS), Água Tropical (AT), e Água Costeira (AC). Essas massas de água apresentam uma dinâmica temporal que depende principalmente do vento (direção, intensidade e tempo de atuação), das correntes e do relevo submarino. A dinâmica dessas massas d'água afeta o desenvolvimento da biomassa fitoplanctônica, uma vez que diferentes porcentagens de mistura entre AC, AT e ACAS podem ser encontradas na coluna de água, correspondendo a diferentes condições químicas e biológicas (Aidar et al., 1993).

A área é ocupada pela $\mathrm{AC}$ durante a maior parte do ano, sendo caracterizada por salinidades entre 32 e 35 e temperaturas maiores do que $20^{\circ} \mathrm{C}$. A AC é uma mistura entre a água doce de origem continental com águas de plataforma continental (Castro- 
Filho et al., 1987). Intrusões de ACAS são frequentes no verão, sendo caracterizada por temperaturas maiores que $6^{\circ} \mathrm{C}$ e menores que $20^{\circ} \mathrm{C}$ e salinidades entre 34,6 e 36 (Silveira et al., 2000). A ACAS origina-se na convergência subtropical e cobre o fundo da plataforma continental externa até aproximadamente $70 \mathrm{~m}$ de profundidade. $\mathrm{O}$ limite mais profundo para essa massa d'água está em torno de $800 \mathrm{~m}$ (Pierre et al., 1991) e o limite mais superficial está a $10 \mathrm{~m}$ no verão e a 70 m no inverno (Castro-Filho et al., 1987; Silveira et al., 2000). A Água Tropical (AT) caracteriza-se por ser quente e salina (temperatura $>20^{\circ} \mathrm{C}$ e Salinidade $>36,4$ ) e interage com a ACAS formando a Corrente do Brasil (Silveira et al., 2000).

A AC é uma massa pobre em nutrientes e a biomassa fitoplanctônica de Ubatuba é limitada principalmente por nitrogênio. Essa limitação leva a uma diminuição da razão de crescimento das populações presentes e as formas de nano e picoplâncton apresentam-se melhor adaptadas a explorar eficientemente as baixas concentrações de nutrientes disponíveis, tornam-se largamente dominantes (Gaeta et al., 1995; Francos, 1996). Dessa forma, a limitação da produção nova pela baixa concentração de nutrientes nas águas de Ubatuba favorece a dominância de fitoflagelados durante todo o ano ( $85 \%$ do fitoplâncton total), já que estes organismos necessitam de menos nutrientes para sua sobrevivência (Aidar et al., 1993).

A região se encontra na parte oeste do giro subtropical anticiclônico, presente no Atlântico Sul em latitudes médias (alta subtropical). A posição e a profundidade da alta subtropical do Atlântico Sul apresentam oscilações sazonais, afetando diretamente a intensidade e também a direção do vento sobre a plataforma continental (Castro et al., 2006). Durante os períodos de primavera e verão, o predomínio de ventos de E-NE induzem o transporte da AC em direção ao oceano na camada de Eckman superficial que é compensado pelo transporte da ACAS no sentido contrário, ocupando as camadas subsuperficiais, gerando a estratificação da coluna de água e a formação de uma termoclina sazonal (Castro-Filho et al., 1987).

A presença da ACAS, uma massa d'água fria e rica em nutrientes, sobre o domínio interno da plataforma continental (10 a $50 \mathrm{~m}$ de profundidade), promove incremento de nutrientes na zona fótica, ocorrendo florescimentos esporádicos de organismos planctônicos, principalmente diatomáceas, e o incremento da produção nova na região (Susini-Zillmann, 1990; Aidar et al., 1993; Gaeta et al., 1995; Francos, 1996; Rocha et al., 2003). O aumento da ocorrência de chuvas e tempestades características da estação promove maior input de matéria suspensa, sedimento e matéria orgânica de 
origem continental, que também contribuem para o aumento da produtividade (Mahiques, 1995; Gaeta et al., 1999). Estudos realizados por Alves (2009) com biomarcadores lipídicos na região de Ubatuba mostraram que, principalmente durante o verão, as maiores contribuições da MO sedimentar provém de diatomáceas fitoplanctônicas.

No outono-inverno, os ventos de quadrante sul (atribuídos às frentes frias) causam um empilhamento da Água Tropical (AT) em direção à costa e um recuo da ACAS em direção à quebra da plataforma. Este padrão, juntamente com o esfriamento das águas superficiais e a intensificação de misturas devido aos ventos fortes, torna as águas próximas à costa quase homogêneas, havendo uma maior interação de AT e AC (Castro-Filho et al., 1987). O aumento de frentes frias e homogeneidade da coluna de água durante esta época do ano tornam a ressuspensão e regeneração de nutrientes os principais fatores dirigindo a produtividade primária na região (Sassi \& Kutner, 1982).

Segundo Mahiques et al. (2004), a dinâmica complexa dessas três massas d'água controla os processos de sedimentação na margem continental sudeste brasileira, que apresenta uma complexa distribuição dos sedimentos, onde a granulometria e matéria orgânica se configuram espacialmente em manchas. Vários estudos granulométricos feitos na região de Ubatuba (ver Conti, 2004; Quintana, 2004; 2008), e na área de estudo (Alves, 2009), demonstram que a área de plataforma interna de Ubatuba apresenta predominância de material fino, como argila, silte e areia fina e muito fina, sendo encontrados valores pequenos de diâmetro médio do grão e baixo grau de seleção.

Apesar da grande proximidade da Mata Atlântica presente na região de Ubatuba, a falta de grandes rios limita a contribuição de carbono orgânico terrestre a época de chuvas (verão), caracterizando a mínima contribuição terrestre no sedimento da região de Ubatuba, que parece ser dominada por aporte de material orgânico de origem autóctone fitoplanctônica e microfitobêntica (Pereira, 2008; Yoshinaga et al., 2008; Alves, 2009).

Dessa forma, foram feitos experimentos em microcosmos onde se pretendeu observar como esses eventos naturais afetam o sedimento e coluna de água da região. Além disso, cabe ressaltar que foram realizadas adicionalmente a esse estudo medidas de fluxos de nutrientes sedimento-água, sendo possível avaliar a degradação da matéria orgânica sedimentar e quais organismos estiveram envolvidos no processo.

A identificação e o entendimento dos mecanismos que controlam a distribuição dos micro-organismos envolvidos nas transformações de compostos orgânicos (i.e. 
substratos) representam um dos maiores desafios na Oceanografia Biológica contemporânea (Arrigo, 2005). Um número cada vez maior de pesquisadores vem aplicando técnicas moleculares avançadas, tanto genéticas (e.g. genoma de comunidades do bacterioplâncton in situ; DeLong, 2005) como geoquímicas (análises isotópicas de compostos orgânicos específicos; Orphan et al., 2001), para entender o funcionamento dos processos biogeoquímicos em diversos ambientes marinhos. Cada vez mais informações sobre a comunidade bacteriana do sedimento têm sido publicadas, porém no Brasil pouco se conhece sobre a caracterização filogenética das comunidades microbianas, e ainda muito menos sobre as forçantes ambientais que influenciam essas relações. Dessa forma, esse estudo irá providenciar informações inéditas sobre a estrutura da comunidade bacteriana na região além de observar como os microorganismos do sedimento respondem a variações ambientais naturais que geralmente ocorrem na área de estudo.

\subsection{Detalhamento do desenho experimental}

O objetivo geral dos ecologistas microbianos marinhos é predizer e entender a abundância, distribuição e o papel dos micro-organismos no ambiente marinho. Os

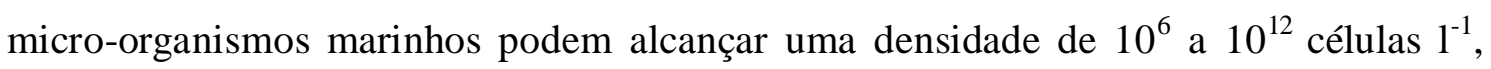
ocupando nano a microlitros de espaço por indivíduo. Estes organismos possuem taxas de crescimento altas que resultam em tempos de geração menores do que um dia. Processos que operam em curtas escalas temporais e espaciais são, portanto, de grande importância para os microbiologistas marinhos (Duarte et al., 1997). Devido à influência de processos físicos e biológicos nos processos que ocorrem em menor escala (através dos processos de transferência de energia e tróficos), micro-organismos marinhos são expostos aos efeitos dos processos físicos e biológicos em uma grande variedade de escalas. Como resultado, a interação entre os processos relevantes ao estudo da ecologia microbiana marinha são particularmente complexos, e demandam a manipulação experimental dos fatores relevantes a cada comunidade, para conhecer sua significância e interação (Carpenter \& Kithell, 1992; Duarte et al., 1997).

Para a decisão do desenho experimental foi realizado um levantamento bibliográfico de artigos publicados em algumas das principais revistas de ecologia microbiana (Microbial Ecology, Aquatic Microbial Ecology, Applied and Environmental Microbiology, Journal of Experimental Marine Biology and Ecology e 
Marine Ecology Progress Series) nos quatro últimos anos (janeiro de 2006 a agosto de 2009). Foi encontrado um total de 5012 artigos publicados, de onde foram selecionados artigos referentes a estudos experimentais (em laboratório e em campo), abordando influências físicas, químicas e biológicas nas comunidades marinhas. Os artigos selecionados somaram 450, representando apenas $9 \%$ do total. Os outros $91 \%$ dos artigos encontrados foram referentes a uma grande variedade de estudos, tanto experimentais como observacionais, no ambiente terrestre e marinho (metodologia, manipulações de organismos isolados e observações de variações espaciais e temporais). Dos artigos selecionados (i.e. 450), 217 apresentou estudos realizados no ambiente bêntico marinho ( $48 \%$ dos selecionados), a grande maioria referente a manipulações da macro e meiofauna. Porém, como toda manipulação do sedimento atinge a comunidade microbiana, estes artigos foram selecionados. Apenas $9 \%$ dos artigos abordando o ambiente bêntico foram relacionados a medidas de micro-organismos, o que correspondeu a apenas $0,4 \%$ do total de artigos publicados.

Dentre os artigos selecionados, destacaram-se a forma de manipulação do sedimento, manutenção do sedimento em laboratório e tamanho dos contêineres utilizados, tratamentos realizados e tempo de duração dos experimentos. Foi encontrada uma grande variedade de experimentos, apesar da grande maioria dos artigos tratarem de manipulações com organismos da macrofauna e sua influência no sedimento.

a. Forma de coleta do sedimento

O sedimento coletado na área de estudo pode ser levado para o laboratório em testemunhos intactos ou suas características podem ser modificadas por diversas manipulações, antes de serem distribuídos nos arranjos experimentais. Na maior parte dos artigos, os sedimentos coletados passaram por manipulações para homogeneizar o sedimento e para retirada da fauna antes de serem distribuídos nos arranjos experimentais. O sedimento coletado foi geralmente peneirado ( 1 ou $0,5 \mathrm{~mm}$ de malha) para retirada da macrofauna e grânulos do sedimento (e.g. Viitasalo-Frösén et al., 2009; Cook et al., 2007; Jensen et al., 2007; Nascimento et al., 2009). Em artigos referentes a análises da comunidade microbiana, o sedimento é geralmente peneirado para eliminar a fauna, porém tais defaunações podem também ser feitas a partir do congelamento do sedimento e de hipóxia (Timmermann et al., 2008).

Para a confecção do experimento do presente projeto, foi decidido pela homogeneização e defaunação do sedimento por meio de peneiramento em $1 \mathrm{~mm}$ de 
malha. A escolha pelo peneiramento deveu-se ao menor impacto que esse procedimento tem na comunidade microbiana e nos fluxos bênticos (Stocum \& Plante, 2006).

b. Tamanho e duração

Experimentos variam de pequenos sistemas laboratoriais extremamente simples e de curto período de incubação (e g. Linares, 2006; Veuger \& Middelburg, 2007; Willkomm et al., 2008), tubos transparentes de vários tamanhos (variando de 3 a $30 \mathrm{~cm}$ de diâmetro) (Duport et al., 2006; Larson et al., 2007; Evrard et al., 2008), chegando a grandes sistemas providos de complexas câmaras ou piscinas, que permitem grandes tempos de incubação (Maire et al., 2006; Karl et al., 2007).

Para o presente projeto foi escolhido um sistema com tubos transparentes de 10 $\mathrm{cm}$ de diâmetro interno e $50 \mathrm{~cm}$ de comprimento, que foi mantido por um total de 30 dias de manipulações experimentais. A maior parte dos artigos que mantiveram seus experimentos por esse período utilizou sistemas do mesmo tamanho ou menor que o escolhido.

c. Tempo de aclimatação e condições experimentais

Em todos os artigos avaliados, as condições de laboratório (temperatura, salinidade e iluminação) foram mantidas constantes de acordo com o observado em campo, no local de coleta, com exceção daqueles experimentos que visavam respostas a variações desses fatores. Em geral, um fluxo contínuo de água do local de coleta das amostras é mantido durante os experimentos. O tempo de aclimatação do sedimento às condições de laboratório variou consideravelmente, não sendo observado um padrão específico. Nos experimentos com comunidades microbianas, o tempo de aclimatação foi em média de 2 dias. Um estudo realizado por Stocum \& Plante (2006) mostra que os fluxos de nutrientes se estabilizam rapidamente em experimentos nos quais há retirada da macrofauna por peneiramento. Nesses, a comunidade bacteriana parece atingir sua dinâmica natural em dois dias.

No presente estudo foi decidido pela manutenção dos testemunhos em condições de temperatura e salinidade observadas em campo, com fluxo e circulação interna de água (coletada no local de amostragem). O sedimento foi aclimatado por 5 dias antes do início dos tratamentos. 


\subsubsection{Coleta do material e montagem experimental}

Para ambos os experimentos testemunhos de sedimento intactos foram coletados com um mini-multicorer que possui a capacidade de coletar até três testemunhos (cilindros de acrílico de $10 \mathrm{~cm}$ de diâmetro e $50 \mathrm{~cm}$ de altura) simultaneamente (Figura 1.2a). Cada testemunho foi fatiado a bordo em quatro profundidades (0-2, 2-5, 5-10 e 10-20 cm) e armazenado em caixas plásticas onde o sedimento de todos os testemunhos foi homogeneizado respeitando-se as camadas. Na base de Ubatuba, o sedimento de cada caixa foi peneirado separadamente em peneira de $1 \mathrm{~mm}$ de malha para a retirada da macrofauna e porções grossas do sedimento (Figura 1.2b). Após peneiramento, a coluna sedimentar foi remontada em testemunhos de acrílico com $10 \mathrm{~cm}$ de diâmetro interno e $50 \mathrm{~cm}$ de altura, respeitando a ordem das fatias e preservando as comunidades microbianas nas diversas profundidades do sedimento (Figura 1.2c). Isto foi feito para eliminar a influência da macrofauna e diminuir a variabilidade da resposta, isolando os fatores relacionados à microbiota e meiofauna. Após a montagem, os testemunhos foram acondicionados em 3 caixas de 372 litros $(58 \times 65 \times 98 \mathrm{~cm})$, contendo água coletada na estação de coleta. Cada caixa conteve apenas um tratamento sem comunicação entre eles. O sistema foi mantido em uma sala com temperatura controlada no Laboratório de Integração de Processos Oceanográficos (LIPO) em Ubatuba (SP), mantendo a temperatura da água constante a $19^{\circ} \mathrm{C}$ sem iluminação. Cada caixa recebeu circulação interna constante através de bombas submersas e aeração (Figura 1.3). Após aclimatação por 5 dias, três testemunhos foram tomados para as análises $(\mathrm{t}=0)$. 


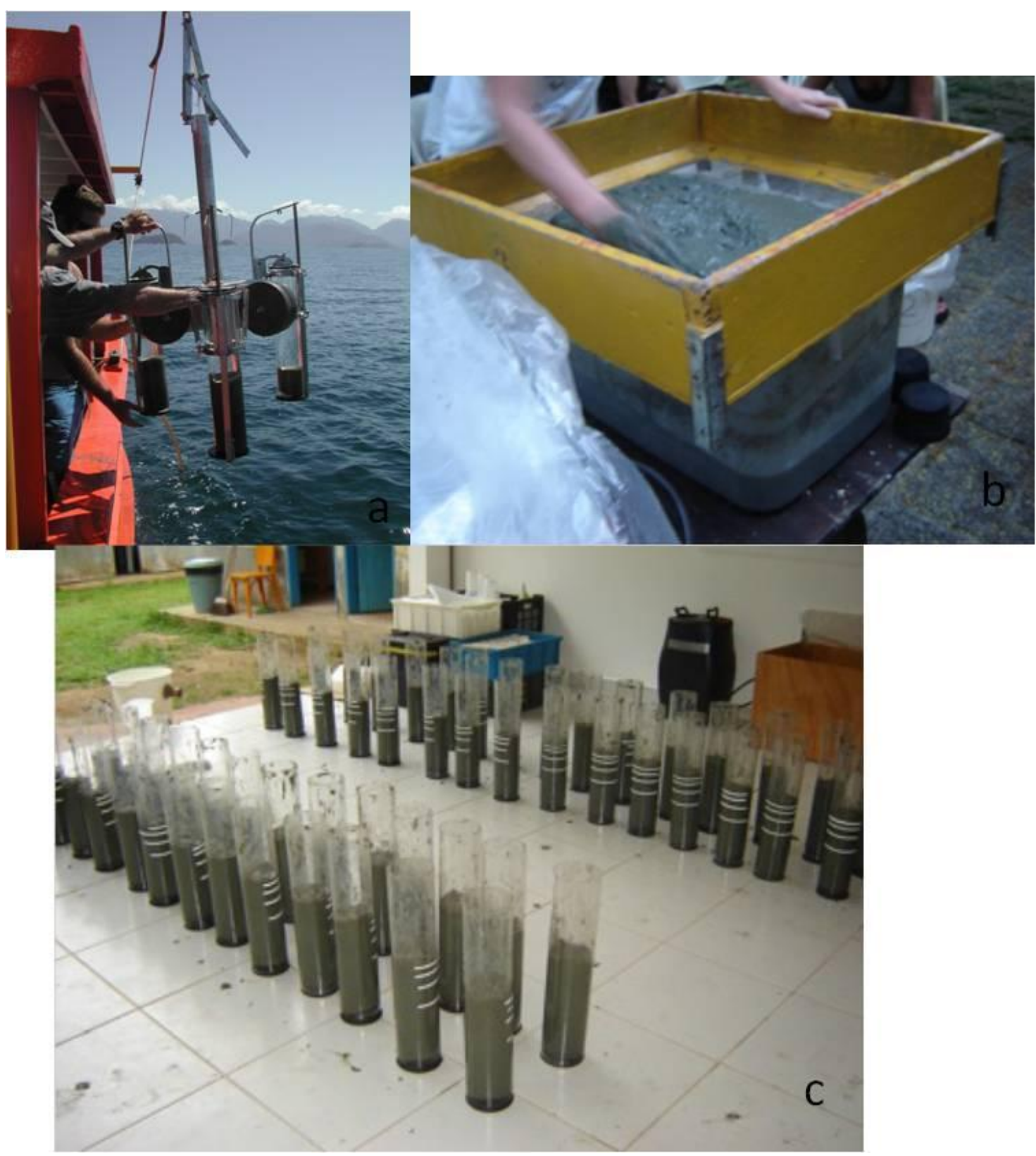

Figura 1.2. a. Mini-multicorer utilizado durante as primeiras coletas do presente projeto; b. Sedimento sendo peneirado em malha de $1 \mathrm{~mm}$ após coleta; c. Bateria de testemunhos sendo remontados no LIPO. 

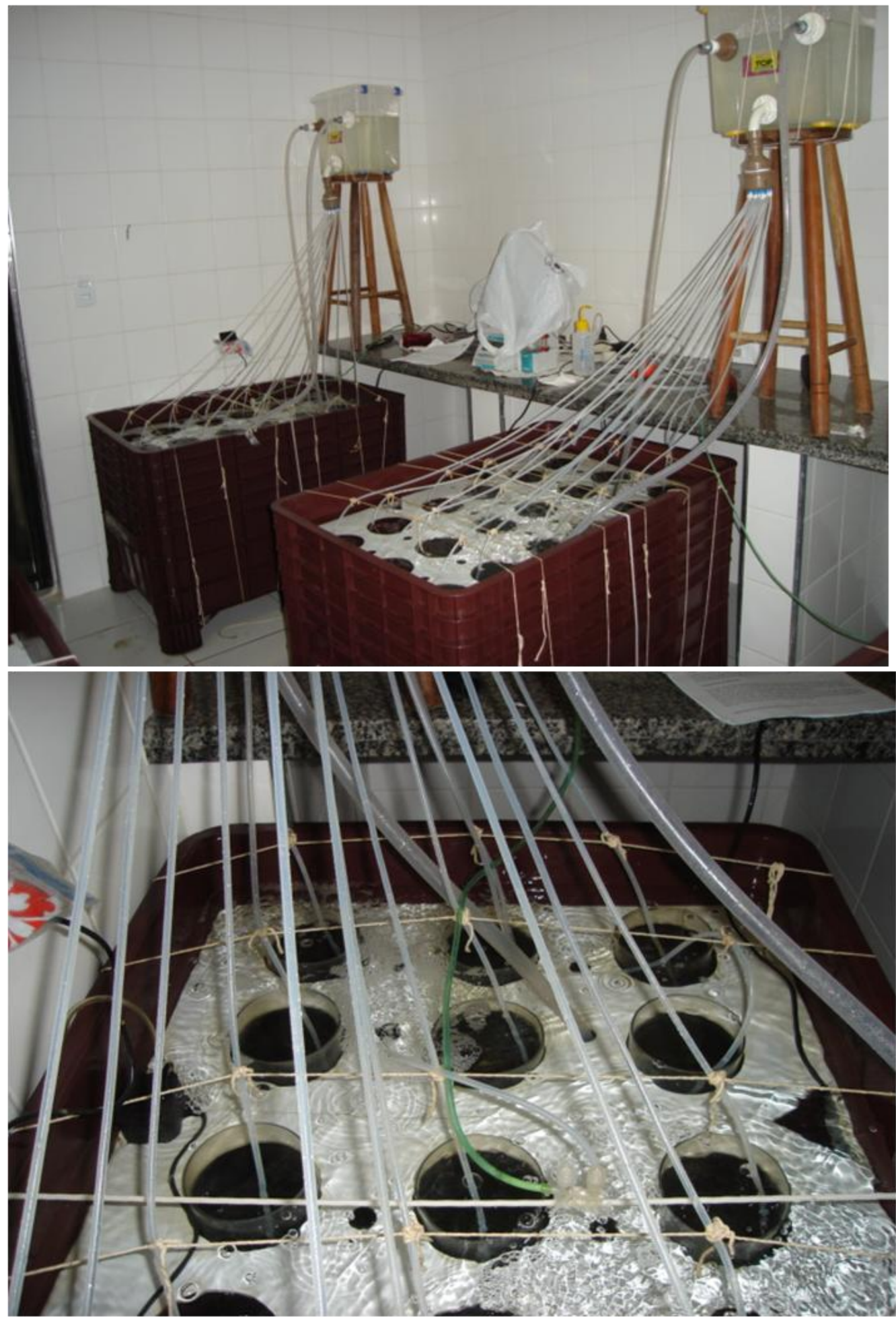

Figura 1.3. Experimentos sendo mantidos em sala com temperatura controlada a $19^{\circ} \mathrm{C}$ no LIPO, na Base Norte do IOUSP em Ubatuba-SP. Testemunhos mantidos por um sistema de circulação interna para garantir a oxigenação do sedimento. 
Dois experimentos de diferentes tratamentos foram realizados:

\section{a. Enriquecimento orgânico}

Diversos estudos na região de Ubatuba observaram uma dominância de fitoflagelados na composição fitoplanctônica (Sassi \& Kutner, 1982; Susini-Zillmann, 1990; Aidar et al., 1993; Francos, 1996). Segundo Smetacek (1988) esse grupo é responsável pela maior fração do fitoplâncton quando a biomassa é baixa, ou seja, quando as condições de crescimento são desfavoráveis. Dessa forma, a limitação da produção nova pela baixa concentração de nutrientes nas águas de Ubatuba favorece a dominância de fitoflagelados durante todo o ano ( 85\% do fitoplâncton total), já que estes organismos necessitam de menos nutrientes para sua sobrevivência (Aidar et al., 1993). Os fitoflagelados são formados pelos grupos Chlorophyceae, Prasynophyceae, Chrysophyceae e Prymnesiophyceae (exceto cocolitoforídeos). Dentre estes grupos, o gênero Tetrasselmis foi identificado na região de Ubatuba e outras regiões costeiras (Francos, 1996; Saldanha, 2008). Esse organismo é cultivado no Laboratório de Cultivo de Microalgas do IOUSP, cuja cepa foi isolada de águas de Ubatuba, sendo a única espécie de fitoflagelado da região cultivada no instituto. No presente estudo, este organismo foi escolhido para os experimentos de enriquecimento para verificação das respostas microbianas.

As diatomáceas são o segundo grupo mais abundante na região de Ubatuba (Susini-Zillmann, 1990; Aidar et al., 1993; Francos, 1996), sendo principalmente relacionadas à intrusão da ACAS (Susini-Zillmann, 1990; Aidar et al., 1993; Francos, 1996; Saldanha-Corrêa \& Gianesella-Galvão, 2004). Entre as diatomáceas, as espécies Leptocylindrus danicus e Dactyliosolen fragilissimus parecem ser as mais abundantes nesta época do ano, diminuindo drasticamente sua abundância durante os meses de inverno (Susini-Zillmann, 1990; Aidar et al., 1993; Francos, 1996). Essas diatomáceas não são cultivadas no Laboratório de Cultivo de Microalgas Marinhas (IO-USP) e, portanto, decidiu-se por utilizar a diatomácea Phaeodactilum tricornutum também muito encontrada na região.

Esse experimento foi desenhado com dois tratamentos e um controle, com diferentes adições de fitoplâncton num total de 54 testemunhos totalizando 30 dias de experimento: 1) 18 testemunhos com fitoflagelado (Tetrasselmis); 2) 18 testemunhos com diatomáceas (Phaeodactilum tricornutum); e 3) 18 testemunhos controle sem adição algal. As microalgas foram adicionadas em quantidades tal que excedessem em 
cinco vezes o máximo de clorofila encontrado nas águas de Ubatuba $\left(2,77 \mathrm{mg} \mathrm{ml}^{-1}\right.$; segundo Aidar et al., 1993). Dessa forma, os dois tratamentos receberam a mesma quantidade de clorofila das diferentes microalgas.

\section{b. Ressuspensão do sedimento}

O experimento foi designado para simular uma intensa, porém curta, passagem de frente fria na região, seguido por um período de calmaria em um total de 30 dias de experimento. Para tanto, 18 testemunhos foram sujeitos a uma ressuspensão do sedimento através de bombas de aquário que foram colocadas a uma distância aproximada de $15 \mathrm{~cm}$ acima da coluna sedimentar (Figura 1.4). A bomba utilizada possui uma vazão total de $280 \mathrm{~L} / \mathrm{h}$ o que proporcionou uma ressuspensão de aproximadamente cinco $\mathrm{cm}$ da coluna sedimentar. $O$ evento de ressuspensão foi mantido por um período de $12 \mathrm{~h}$, durante o qual os testemunhos ficaram fechados. Após esse tempo os testemunhos foram abertos e o sistema foi mantido normalmente como mostrado anteriormente.

Em ambos os experimentos, as amostragens foram realizadas seis vezes em 30 dias ( $\mathrm{t}=1,2,5,10,20$ e 30 dias após o tratamento). A cada amostragem três testemunhos de cada tratamento e do controle foram amostrados. Primeiramente foi amostrada a água sobrejacente de cada testemunho, para medida de nutrientes (nitrito, nitrato, fosfato, amônia e silicato) e fluxos de oxigênio e gás carbônico, e completado novamente com água do sistema. Os testemunhos foram selados com tampas de PVC e transferidos para um novo sistema com água (caixa de 372 1), onde um sistema de ímãs com rotação magnética foi montado para manter a circulação interna abaixo do limite de ressuspensão (Figura 1.5). Após incubação por duas a três horas os testemunhos foram amostrados novamente para as análises de água sobrejacente. Os testemunhos foram então fatiados em dez horizontes $(0-1,1-2,2-3,3-4,4-5,5-8,8-11,11-14,14-17$ e 17 $20 \mathrm{~cm}$ ) de profundidade para as análises sedimentares que serão descritas nos capítulos subsequentes. 

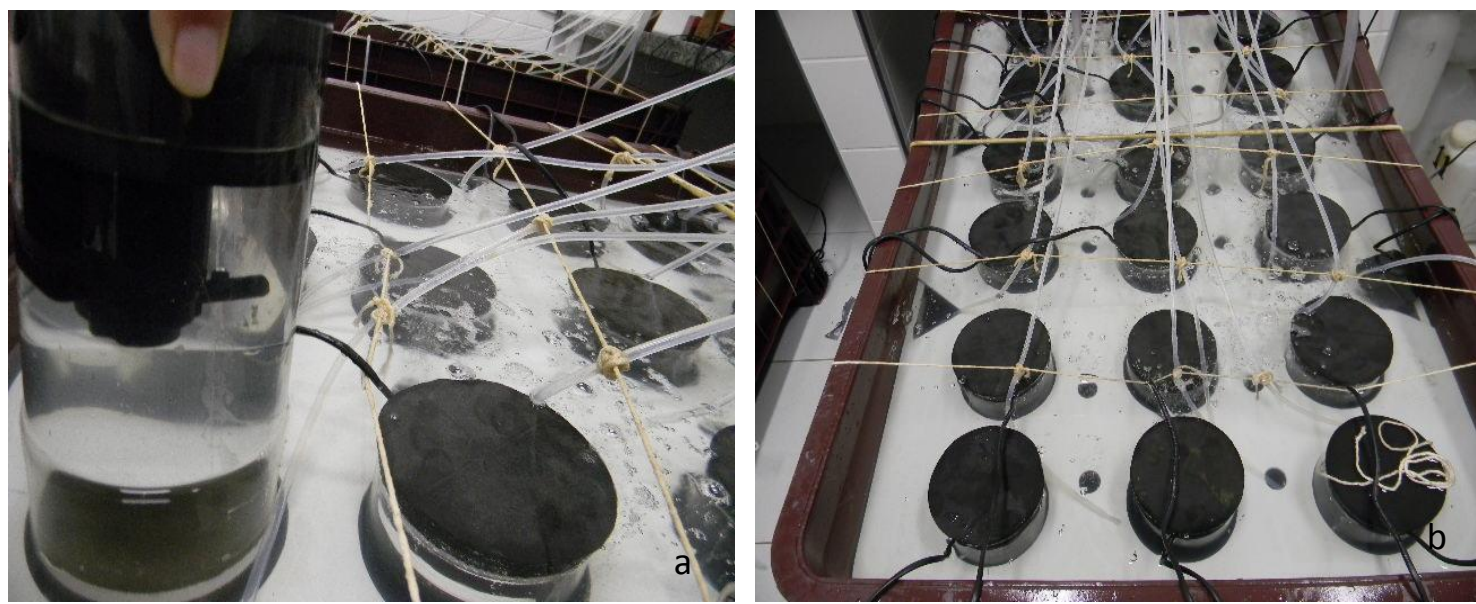

Figura 1.4. a. Bomba colocada no interior dos testemunhos para a realização da ressuspensão do sedimento. b. Dezoito testemunhos fechados durante a realização do experimento de ressuspensão do sedimento.

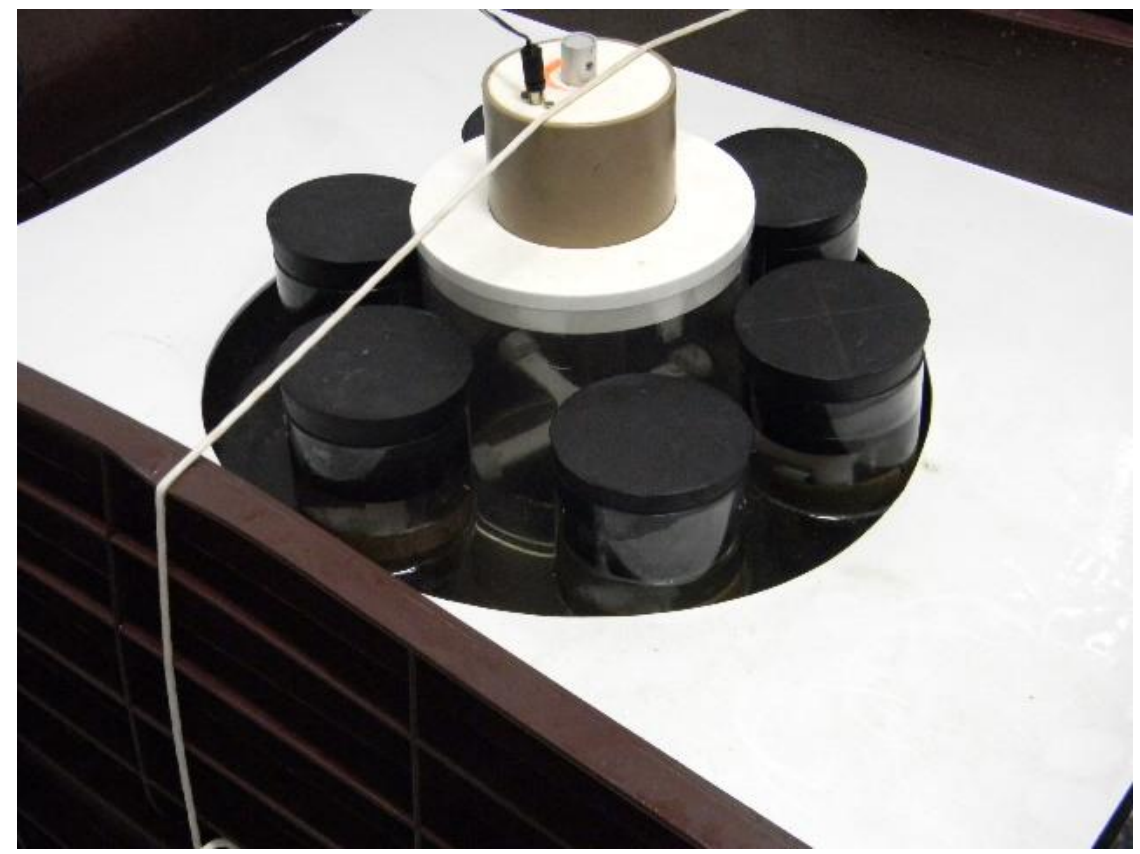

Figura 1.5. Incubação dos testemunhos mostrando o sistema de circulação magnética interna para cada tubo. 


\section{Capítulo 2: Efeito da matéria orgânica derivada do plâncton na comunidade microbiana de sedimentos costeiros marinhos}

\subsection{Introdução}

Sedimentos marinhos representam um dos mais complexos hábitats microbianos da Terra, e a comunidade microbiana bêntica desempenha um importante papel nos ciclos biogeoquímicos no ambiente marinho. Isto é resultado de sua abundância elevada (superior a $10^{8}$ células por grama de sedimento) e a sua função-chave em mediar e regular as transformações e especiações dos principais elementos bioativos. Vários fatores influenciam a comunidade bacteriana de sedimentos (Bordalo, 1993; Ikenaga, 2010), como temperatura (Thamdrupt \& Fleischer, 1998; Kirchman et al., 2005), qualidade da matéria orgânica (Bisset et al., 2007; Powell et al., 2003) e estrutura da comunidade (Wobus et al., 2003). No entanto, determinar quais os fatores mais importantes na estruturação das comunidades microbianas torna-se muito difícil devido a interação que ocorre entre eles.

Grandes quantidades de matéria orgânica particulada (MOP) são depositadas em sedimentos marinhos, o que estimula um aumento da degradação mediada por micro-organismos (Henrichs, 1992). Nas áreas costeiras e de plataforma este processo é intensificado devido à alta produtividade (ca. 30\%), a alta sedimentação e enterramento de carbono orgânico (Berner, 1980; Hedges \& Keil, 1995; Wollast, 2002; Duarte et al., 2004). Em média, $25-50 \%$ da matéria orgânica produzida nas plataformas é degradada nos sedimentos (Suess, 1980; Walsh, 1991).

A MOP que alcança os sedimentos marinhos serve como uma fonte de alta qualidade alimentar para muitas formas bênticas (Graf, 1992), sendo um mecanismo de estruturação potencialmente importante nos sedimentos marinhos. Micro-organismos reagem rapidamente à sedimentação de fitoplâncton e aumento de clorofila sedimentar, geralmente com um aumento na sua biomassa, densidade e atividade (Danovaro et al., 1999; Pfannkuche et al., 2000; Smith et al., 2002; Rusch et al., 2003). No entanto, possíveis mudanças na composição e diversidade das comunidades bênticas bacterianas em resposta a tais insumos não são completamente conhecidos (Rink et al., 2007).

Vários estudos experimentais têm demonstrado que diferentes componentes monoméricos e poliméricos de carbono orgânico dissolvido, quer através do 
fornecimento direto ou induzida experimentalmente, podem selecionar subcomunidades ou populações específicas de bacterioplâncton (Lebaron et al., 1999; Riemann et al., 2000; Abell \& Bowman, 2005). A composição específica da matéria orgânica de diferentes organismos fitoplanctônicos também parece ser um fator importante na seleção de comunidades e populações distintas de bactérias planctônicas (Grossart, 1999; Schäfer et al., 2002; Grossart et al., 2005). O estudo e conhecimento da associação entre diferentes tipos de MOP lábil (ou organismos planctônicos diferentes), atingindo o sedimento e a resposta da comunidade microbiana específica necessita de mais investigação uma vez que as bactérias sedimentares são de grande importância para a reciclagem e decomposição de matéria orgânica tanto em sedimento quanto na coluna de água.

A identificação e compreensão dos mecanismos que controlam a distribuição dos micro-organismos envolvidos nas transformações dos compostos orgânicos (ou seja, substratos) representam um grande desafio contemporâneo na oceanografia biológica (Arrigo, 2005). No Brasil, nosso conhecimento da comunidade microbiana sedimentar limita-se a regiões de mangues (e g. Brito et al., 2008; Gomes et al., 2008; Oliveira, 2007; Silva et al., 2008), e pouco se sabe sobre a caracterização filogenética de comunidades microbianas oceânicas e muito menos sobre os fatores ambientais que influenciam essas comunidades. Assim, este estudo fornece informações inéditas sobre a estrutura da comunidade bacteriana, bem como, observa a resposta dos microorganismos a variações ambientais que ocorrem na área de estudo.

O objetivo do estudo foi investigar a resposta da comunidade microbiana a chegada de MOP derivada da produção fitoplanctônica ao sedimento e verificar se diferenças ocorrem quando diferentes espécies de fitoplâncton são depositadas. Para avaliar essas respostas um experimento laboratorial foi realizado em Nov/Dez de 2009 onde as características sedimentares e a comunidade microbiana foram monitoradas por um total de 30 dias após a adição de diferentes tipos de microalgas à superfície do sedimento. 


\subsection{Material e Métodos}

\subsection{1. Área de estudo}

O litoral norte do Estado de São Paulo caracteriza-se por apresentar um padrão mesotrófico de produtividade. A produção primária e os padrões de sedimentação são principalmente influenciados pela interação sazonal de três massas de água, a Água Costeira (AC), a Água Tropical (AT) e Água Central do Atlântico Sul (ACAS) (CastroFilho et al., 1987). Nos períodos de Novembro a Março a dominância de ventos E-NE induz a intrusão da ACAS, uma massa de água fria e rica em nutrientes, em direção à costa, aumentando a produção primária e propiciando a ocorrência de florescimentos fitoplanctônicos, principalmente diatomáceas (Gaeta et al., 1995). Entre abril e outubro, a prevalência de ventos do quadrante sul favorece o recuo da ACAS, e a maior frequência de frentes frias torna a ressuspensão e regeneração de nutrientes os principais fatores influenciando a produtividade primária na região, que é dominada por fitoflagelados na maior parte do ano. De acordo com Mahiques et al. (2004), a complexa dinâmica das massas de água também controla os processos de sedimentação em toda a margem continental sudeste brasileira. Isso gera uma complexa distribuição de sedimentos, que se apresenta em manchas de tamanho de grão distinta e teor de matéria orgânica. A falta de grandes rios na área limita a contribuição de carbono orgânico terrestre, indicando uma grande contribuição de matéria orgânica derivada de fontes autóctone (i.e., fitoplâncton e microfitobentos) (Yoshinaga et al., 2008).

\subsubsection{Amostragem e montagem experimental}

As amostras foram coletadas na região de Ubatuba, costa norte do estado de São Paulo, na plataforma sudeste brasileira, em uma área de transição entre águas costeiras e de plataforma $\left(23^{\circ} 36.679^{\prime} \mathrm{S}-44^{\circ} 58.598^{\prime} \mathrm{W}\right.$ e $40 \mathrm{~m}$ de profundidade). Os testemunhos foram coletados com um mini-multicorer e fatiado a bordo em quatro profundidades ( 0 2, 2-5, 5-10, 10-20 cm). O sedimento de todos os testemunhos de cada camada foram homogeneizados, peneirados em peneira de $1 \mathrm{~mm}$ e remontado em testemunhos de acrílico com $10 \mathrm{~cm}$ de diâmetro e $20 \mathrm{~cm}$ de coluna sedimentar. Um total de 57 testemunhos foram mantidos em três sistemas separados (dois tratamentos e um controle) sem luz e com oxigenação e circulação em uma sala de temperatura controlada $\left(19^{\circ} \mathrm{C}\right)$. 
Foi escolhido o fitoflagelado Tetrasselmis sp. e a diatomácea Phaeodactylum tricornutum para a adição experimental, por serem espécies comuns ocorrendo na área de estudo e estarem disponível no banco de algas do IOUSP. Antes da adição das algas a clorofila-a das culturas foi quantificada e foi adicionada uma quantidade de clorofila-a cinco vezes superior ao máximo de clorofila encontrado na região (2,77 mg ml¹; Aidar et al., 1993).

Após cinco dias de aclimatação três testemunhos foram tomados para as análises iniciais $(\mathrm{t}=0)$ e as microalgas foram adicionadas à superfície do sedimento. $\mathrm{O}$ experimento foi mantido por um total de 30 dias após a introdução das algas. Amostragens foram realizadas seis vezes nesse período $(\mathrm{t}=24 \mathrm{~h}, 48 \mathrm{~h}, 120 \mathrm{~h}, 240 \mathrm{~h}, 480 \mathrm{~h}$, $720 \mathrm{~h}$ após a adição), durante o qual foram analisados três testemunhos de cada tratamento e do controle. Primeiramente os testemunhos foram incubados para análises de fluxo de oxigênio e, posteriormente, os testemunhos foram fatiados e a camada superficial $(0-1 \mathrm{~cm})$ foi amostrada para as análises sedimentares (fitopigmentos, MOT, COT e análises microbianas).

\subsubsection{Fluxo de Oxigênio}

Três testemunhos de cada tratamento e controle foram amostrados em cada período para a determinação do oxigênio dissolvido e cálculo de fluxos sedimento-água. Os testemunhos foram selados durante a incubação e um agitador magnético dirigido por um sistema externo de ímãs manteve a circulação interna constante. A incubação foi feita no escuro por 3-3,5h e amostras para análise de oxigênio foram feitas antes e após a incubação. O método de Winckler foi usado para as análises de oxigênio (Strickland \& Parsons, 1972).

\subsubsection{Características sedimentares}

A matéria orgânica total (MOT) foi obtida através do método de calcinação em forno mufla $\left(550^{\circ} \mathrm{C}\right)$ for 2,5-3h (Byers et al., 1978). Fitopigmentos foram extraídos com acetona $100 \%$ for $24 \mathrm{~h} \mathrm{a}-10^{\circ} \mathrm{C}$ e a absorbância foi medida (665 e $750 \mathrm{~nm}$ ) antes e após acidificação com 0,1 N HCl através de um espectrofotômetro (Plante-Cuny, 1978). As concentrações de clorofila-a e feopigmentos foram calculadas aplicando-se a fórmula sugerida por Lorenzen (1967). O carbono orgânico total (COT) foi estimado pelo 
método de titulação de Walkley-Black modificado para sedimento (Gaudette et al., 1974).

\subsubsection{Densidade de procariotos}

De cada réplica de sedimento amostrada, $1 \mathrm{ml}$ de sedimento foi retirado com seringa estéril e alocado em potes de plástico com $9 \mathrm{ml}$ de formol salino $2 \%$ pré-filtrado em filtro $0,2 \mu \mathrm{m}$. A densidade de procariotos foi determinada através de método de contagem direta em microscópio de epifluorescência, usando um kit de viabilidade Live/Dead (L/D) BacLight (L-7012, Molecular Probes, Eugene, OR; Quéric et al., 2004). A técnica L/D utiliza um kit que contém uma mistura de SYTO 9 como marcador de viabilidade e iodeto propídico como marcador de células com danos de membrana, consideradas como células inviáveis. Dependendo de sua viabilidade, as células florescem em verde (vivas) ou em vermelho (mortas) (Haugland, 1996). Para uma gentil separação das células dos grãos de sedimento, testes com agitação e sonicação foram realizados onde se decidiu pela agitação. As amostras foram diluídas 10.000 vezes após um período de agitação de $15 \mathrm{~min}$. Dois mililitros das amostras diluídas foram coradas com $3 \mu \mathrm{l}$ de 1:1 dos corantes (6.68 M SYTO 9 e 20 M iodeto propídico) e incubadas por 30 min. em temperatura ambiente. A amostra foi filtrada em filtro policarbonato black de $0,2 \mu \mathrm{m}$ e montada em lâmina. Um total de 400 células por amostra foi contado em microscópio de epifluorescência.

\subsubsection{Extração do DNA, PCR e DGGE}

Amostras coletadas para análise da comunidade microbiana foram conservadas em congelador a $-20^{\circ} \mathrm{C}$ até análise. A extração de DNA das amostras de sedimento foi realizada utilizando o PowerSoil DNA Isolation Kit (MoBio Laboratoires, CA, USA) de acordo com as especificações do fabricante. O DNA extraído foi quantificado e sua pureza checada através de medidas de absorbância com espectrofotômetro.

A região variável V3 do gene $16 \mathrm{~S}$ do rRNA foi amplificada do DNA extraído usando os primers 338f-GC e 518r para bactéria. A mistura para as reações de PCR em um total de $50 \mu \mathrm{l}$ consistiu de: $2 \mu \mathrm{l}$ de DNA extraído (aproximadamente $20 \mathrm{ng}$ ), $5 \mu \mathrm{l}$ 10X PCR Buffer (Invitrogen), 1,5 $\mu \mathrm{l} \mathrm{MgCl}_{2}(50 \mathrm{mM}), 0,4 \mu \mathrm{l}$ dNTP (100 mM), $1 \mathrm{U}$ Taq polymerase (Platinum, Invitrogen), água livre de ácido nucléico até completar o volume. O PCR foi realizado através de um termociclador (Eppendorf Mastercycler Personal), nas seguintes condições: $94^{\circ} \mathrm{C}$ por 5 min., seguido por 30 ciclos de $94^{\circ} \mathrm{C}$ por $1 \mathrm{~min}$., 
$55^{\circ} \mathrm{C}$ por 1 min., e $72^{\circ} \mathrm{C}$ por 2 min., com uma extensão do passo final a $72^{\circ} \mathrm{C}$ por 10 min. Todos os produtos finais de PCR foram checados e quantificados por eletroforese em gel de agarose $1 \%(\mathrm{w} / \mathrm{v})$.

Com intuito de reduzir o número de amostras, os produtos de PCR das réplicas foram misturados antes da aplicação no gel de DGGE (eletroforese em gel com gradiente denaturante). Antes da mistura um DGGE foi realizado com as amostras individuais e mostraram uma aceitável semelhança (dados não apresentados). Na análise de DGGE, foi utilizado um gel de poliacrilamida a $8 \%$, com um gradiente de denaturação de 35-60\% (100\% denaturante $7 \mathrm{M}$ ureia, e $40 \%$ formamida). Concentrações similares de produto de PCR foram colocadas no gel e a eletroforese foi realizada em tampão TAE $1 \mathrm{X}$ por $16 \mathrm{~h}$ a uma constante de $60 \mathrm{~V}$ a $60{ }^{\circ} \mathrm{C}$, utilizando o sistema Dcode Universal Mutation Detection System (Bio-Rad Laboratories, Richmond Calif.). O gel foi corado com nitrato de prata modificado de Sanguinetti et al. (1994) e a imagem obtida com o auxílio de um escâner.

\subsubsection{Sequenciamento das bandas de DGGE e análise filogenética}

As bandas dominantes e mais intensas do DGGE foram excisadas e incubadas em água estéril por $30 \mathrm{~min}$. a $70^{\circ} \mathrm{C}$. Um mililitro do sobrenadante foi usado para reamplificação da banda com PCR igual ao utilizado para o DGGE. A mobilidade do fragmento amplificado foi checada quanto à sua posição repetindo-se o DGGE com condições idênticas ao original. O sequenciamento foi conduzido usando o BigDye Terminator v3.1 Cycle Sequencing Kit (Applied Biosystems) pela empresa Genomic Engenharia Molecular, usando o primer 518r. As sequências de DNA foram editadas com o programa Bio-Edit Sequence Alignment Editor e alinhadas com o programa Clustal W software (http://www.ebi.ac.uk/clustalw). As sequências foram comparadas com aquelas depositadas no GenBank usando o Blast algoritmo (http://www.ncbi.nlm.nih.gov/BLAST).

\subsubsection{Análises estatísticas}

As variáveis foram analisadas quanto à normalidade usando o teste Kolmogorov-Smirnov. As diferenças entre tratamentos e controle e entre os tempos amostrados das variáveis obtidas foram testadas a partir de análises de variância (ANOVA one-way ou Kruskal-Wallis). Relações entre as variáveis foram testadas 
através do teste de correlação de Pearson $(n=18)$. Foi realizada uma Análise de Redundância Canônica (RDA; Canoco 4.5; Ter Braak \& Smilauer, 2002) para avaliar a influência dos fatores abióticos na abundância de procariotos. A densidade total dos procariotos e a densidade de vivos foram utilizadas como a matriz resposta (18 amostras; 2 variáveis) e os parâmetros abióticos como matriz explanatória (18 amostras; 5 variáveis).

O DGGE foi analisado através do programa BioNumerics 6.1 (AppliedMaths). Um dendograma foi construído através do coeficiente de similaridade de Dice e pela análise de agrupamento pelo método da distância média não ponderada (UPGMA).

Com o objetivo de estabelecer qual variável melhor explica o perfil de bandas do DGGE, uma Análise de Correspondência Canônica (CCA, CANOCO 4.5) foi realizada. A significância estatística das relações entre a diversidade genética (DGGE) e as variáveis bióticas e abióticas foi avaliada através do teste de Monte Carlo (9999 permutações). Para obervar todas as interações entre o padrão de bandas do DGGE e as variáveis medidas, uma CCA foi realizada (CANOCO 4.5).

\subsection{Resultados}

\subsubsection{Variáveis abióticas}

O consumo de oxigênio aumentou significativamente após a adição das algas, quando comparado com o controle (Figura 2.1). O controle, por outro lado, mostrou sempre uma discreta produção ou um baixo consumo de oxigênio durante a maior parte do experimento (Figura 2.1). Cento e vinte horas após a adição das algas foi observada uma diminuição no consumo de oxigênio nos tratamentos, e um posterior aumento nas medidas subsequentes, alcançando valores significativamente diferentes entre tratamentos e controle após 240h da adição das algas (Figura 2.1).

A matéria orgânica total (MOT) não apresentou mudanças significativas após a adição das algas (Figura 2.2a). Valores de MOT aumentaram continuamente até 240h após a adição de Tetrasselmis, diminuindo posteriormente. Por outro lado, os valores no tratamento com diatomácea e no controle não apresentaram um padrão definido de variação (Figura 2.2a). O carbono orgânico total apresentou uma diminuição significativa $24 \mathrm{~h}$ após a adição de Tetrasselmis, mostrando um posterior aumento e valores mais constantes durante o restante do experimental (Figura 2.2b). 
Após 24h, foi observado um aumento significativo na clorofila-a em ambos os tratamentos, em relação ao valor inicial antes da adição das algas (Figura 2.3a; Tabela 2.1). Os valores então diminuíram significativamente alcançando as menores concentrações de clorofila-a após $720 \mathrm{~h}$ de tratamento (Figura 2.3a; Tabela 2.1). No controle, os valores de clorofila-a diminuíram após $24 \mathrm{~h}$ de experimento, alcançando os menores valores após 480h (Figura 2.3a; Tabela 2.1). Os feopigmentos apresentaram uma menor variação nas concentrações (Figura 2.3b; Tabela 2.1). Em ambos os tratamentos os valores de feopigmentos diminuíram significativamente após $24 \mathrm{~h}$ da adição algal. Após 48h, os valores aumentaram, diminuindo novamente até o fim do experimento (Figura 2.3b; Tabela 2.1). O controle apresentou uma diminuição significativa nos valores de feopigmentos, quando comparado com o inicial (Figura 2.3b; Tabela 2.1). Diferenças significativas entre tratamentos e controle foram observadas $48 \mathrm{~h}$ e $240 \mathrm{~h}$ após a adição das algas (Figura 2.3b).

A análise de correlação de Pearson não mostrou correlação significativa entre nenhuma das variáveis abióticas analisadas.

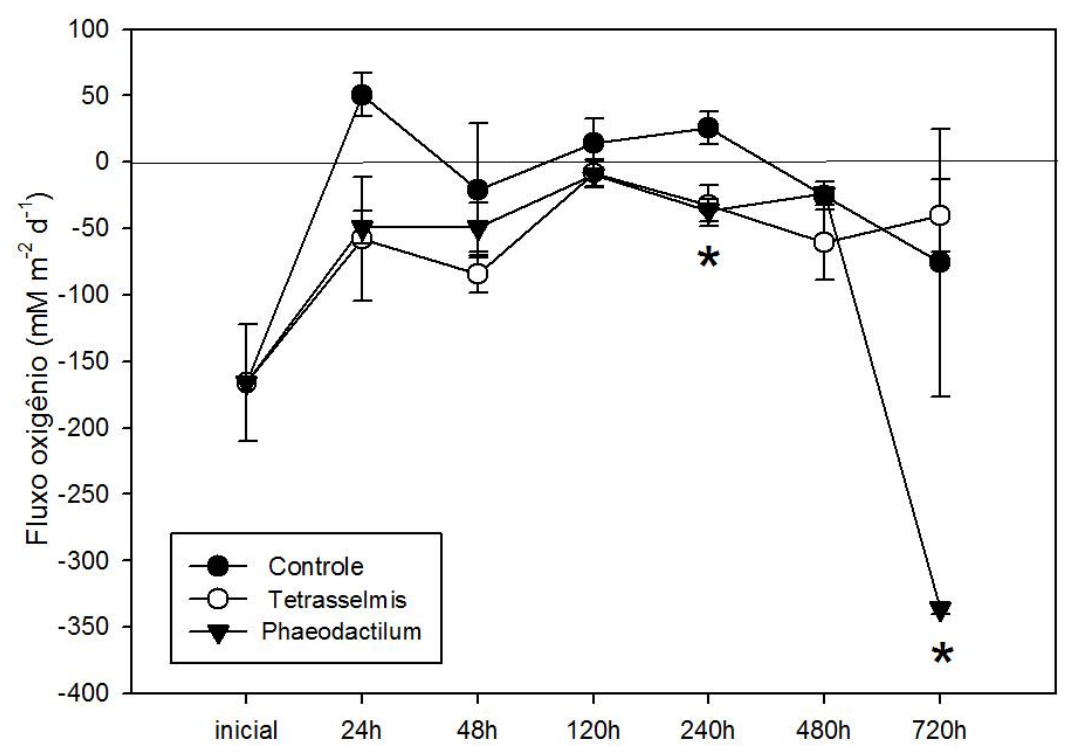

Figura 2.1: Fluxo de oxigênio $\left(\mathrm{mm} \mathrm{m}^{-2} \mathrm{~d}^{-1}\right)$ através da interface sedimento-água (média \pm erro padrão) dentro do tempo experimental. ( $* \mathrm{p}<0.05$, ANOVA, Tukey). 

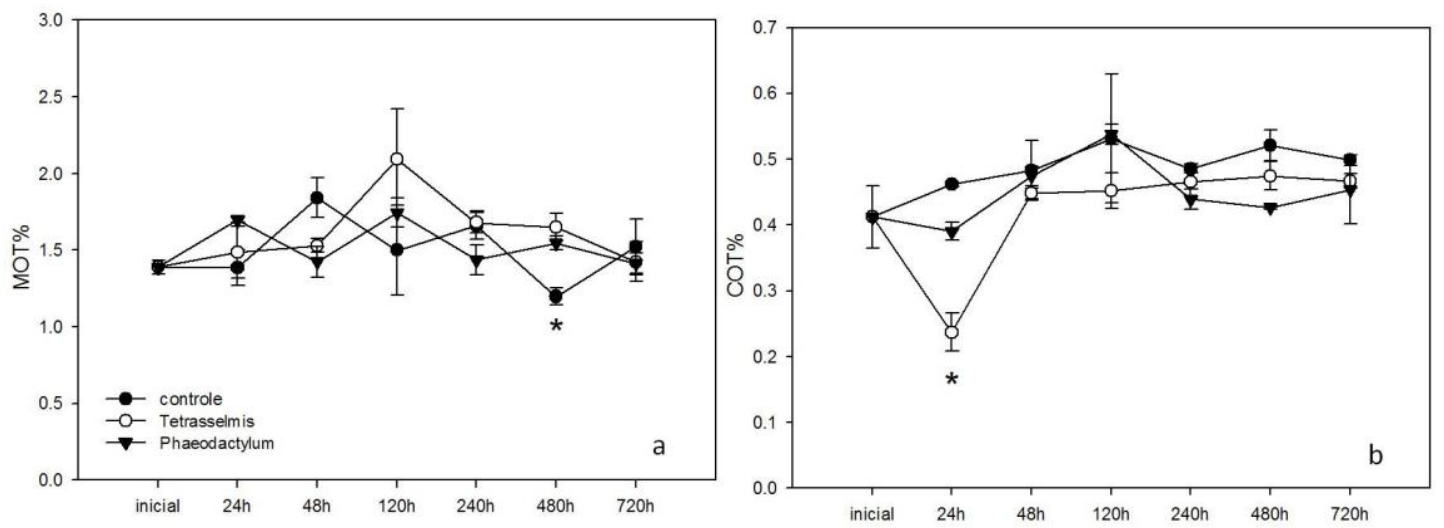

Figura 2.2: Valores de (a) material orgânico total (MOT) e (b) carbono orgânico total (TOC) na primeira camada $(0-1 \mathrm{~cm})$ (média \pm erro padrão) dentro do tempo experimental (horas). (* $\mathrm{p}<0.05$, ANOVA, Tukey).
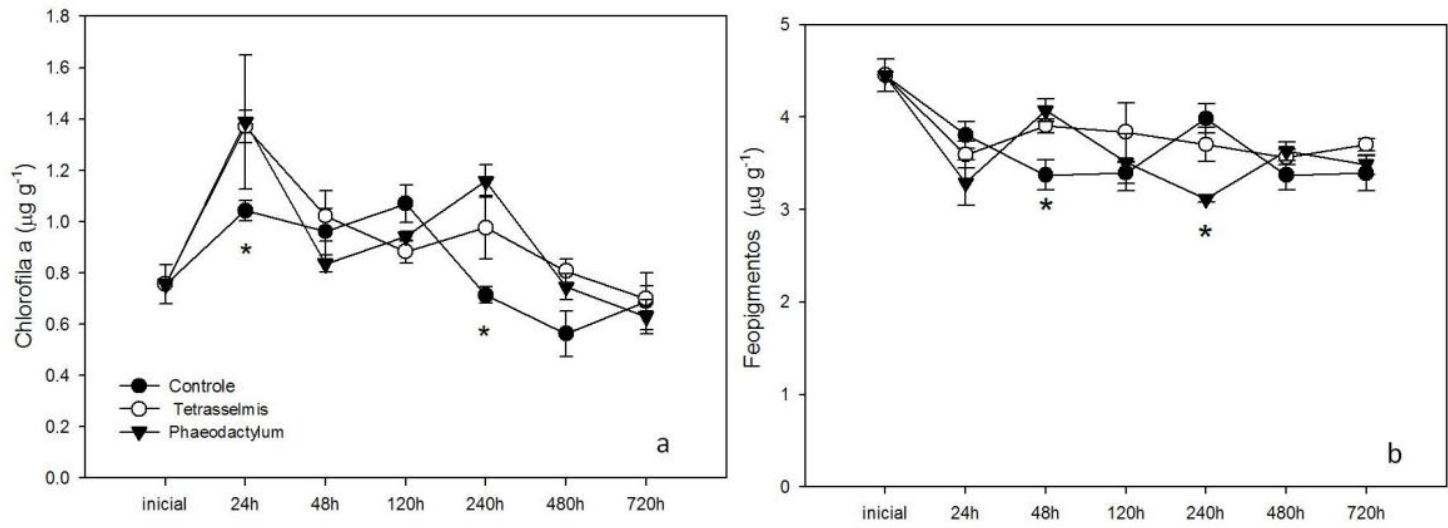

Figura 2.3: Distribuição dos fitopigmentos (média \pm erro padrão) na primeira camada sedimentar $(0-1 \mathrm{~cm})$ dentro do tempo experimental (horas). (* $\mathrm{p}<0.05$, ANOVA, Tukey). (a) clorofila-a (b) feopigmentos.

Tabela 2.1: Análise estatística ANOVA dos valores de clorofila-a e feopigmentos na camada superficial durante o tempo do experimento.

\begin{tabular}{l|l|l|l|l}
\hline \hline & \multicolumn{2}{|l|}{ Clorofila-a } & \multicolumn{2}{l}{ Feopigmentos } \\
\hline & $\mathrm{p}$ & Tukey $(\mathrm{p}<0.05)$ & $\mathrm{p}$ & Tukey $(\mathrm{p}<0.05)$ \\
\hline Tetrasselmis & 0,00 & $\begin{array}{l}\text { inicial } \neq 24 \mathrm{~h} ; 24 \mathrm{~h} \neq 120 \mathrm{~h}, \\
240 \mathrm{~h}, 480 \mathrm{~h}, 720 \mathrm{~h}\end{array}$ & 0,03 & inicial $\neq 24 \mathrm{~h}, 480 \mathrm{~h}$ \\
\hline Phaeodactylum & 0,00 & $\begin{array}{l}\text { inicial } \neq 24 \mathrm{~h} ; 24 \mathrm{~h} \neq 48 \mathrm{~h}, \\
720 \mathrm{~h} ; 120 \mathrm{~h} \neq 720 \mathrm{~h} ; 240 \mathrm{~h} \neq \\
480 \mathrm{~h}, 720 \mathrm{~h}\end{array}$ & 0,00 & $\begin{array}{l}\text { inicial } \neq 24 \mathrm{~h}, 120 \mathrm{~h}, 240 \mathrm{~h}, \\
720 \mathrm{~h} ; 48 \mathrm{~h} \neq 240 \mathrm{~h}\end{array}$ \\
\hline controle & 0,00 & $\begin{array}{l}480 \mathrm{~h} \neq 24 \mathrm{~h}, 48 \mathrm{~h}, 120 \mathrm{~h} ; 120 \mathrm{~h} \\
\neq 720 \mathrm{~h}\end{array}$ & 0,00 & $\begin{array}{l}\text { inicial } \neq 48 \mathrm{~h}, 120 \mathrm{~h}, 480 \mathrm{~h}, \\
720 \mathrm{~h}\end{array}$ \\
\hline \hline
\end{tabular}




\subsubsection{Densidade de procariotos}

A densidade de procariotos na superfície do sedimento $(0-1 \mathrm{~cm})$ variou de 5,9 a $10,7 \times 10^{9}$ células $\mathrm{ml}^{-1}$, mostrando em geral valores mais elevados nos tratamentos em comparação com o controle (Figura 2.4). As densidades de células vivas variaram de 3,7 a 7,2 X10 ${ }^{9}$ células $\mathrm{ml}^{-1}$ e apresentaram o mesmo padrão de variação da densidade total (Figura 2.4). Após 24 h da adição, observou-se um aumento na densidade procariótica, principalmente no tratamento com Tetrasselmis, que foi significativamente maior do que a densidade no controle. Ambos os tratamentos apresentaram valores significativamente mais elevados do que o controle em quase todos os tempos amostrados (Figura 2.4). Temporalmente, observou-se um aumento na densidade de procariotos $24 \mathrm{~h}$ após a adição de Tetrasselmis e 48 horas após a adição de Phaeodactylum (Figura 2.4). No entanto, o aumento significativo na densidade foi observado apenas após a adição Phaeodactylum (Tabela 2.2). A percentagem de células vivas observadas neste estudo foi sempre maior variando de 51 a $82 \%$ (Figura 2.5). Em ambos os tratamentos, observou-se um aumento de células vivas com o tempo, o que não foi observado no controle. Análises de correlação de Pearson mostraram uma correlação positiva significativa apenas entre a densidade total de procariotos e a clorofila-a $(r=0,504 ; \mathrm{p}=0,001)$. Na RDA realizada com ambos, densidade de células vivas e densidade total procariótica os dois primeiros eixos explicaram 33,8\% da variância total das amostras. Clorofila-a e feopigmentos foram os únicos parâmetros que explicaram significativamente a variabilidade da densidade procariótica. O primeiro eixo foi mais fortemente correlacionado com as variáveis, apresentando correlação negativa com os dois parâmetros explanatórios, enquanto o segundo eixo apresentou correlação positiva com feopigmentos e negativa com clorofila-a (Figura 2.6). 

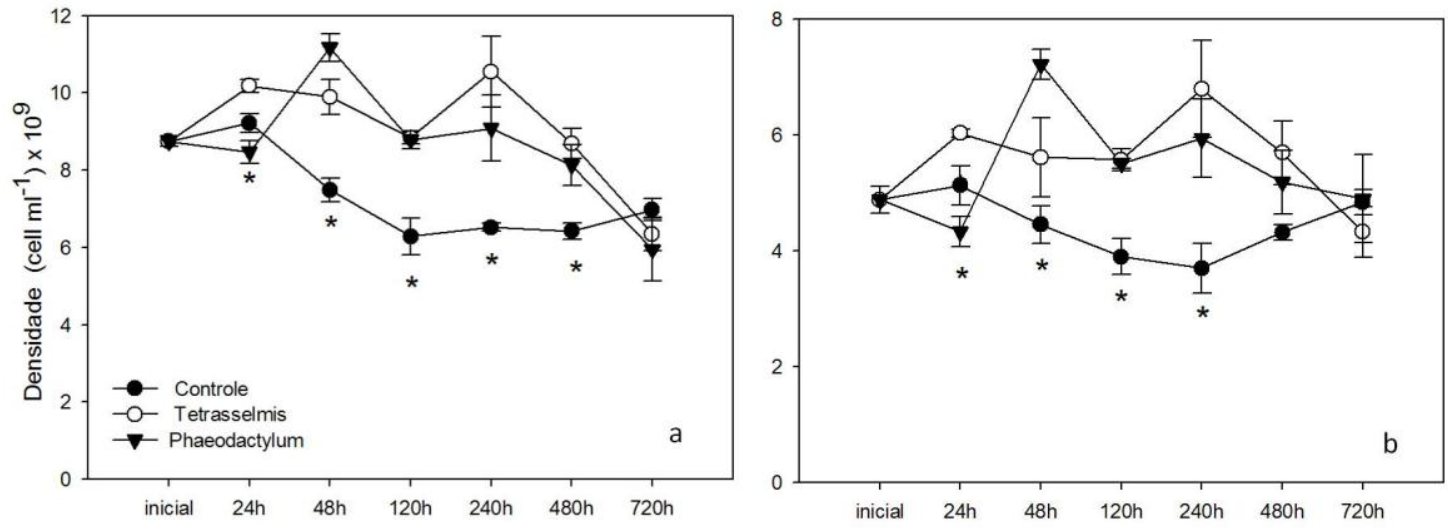

Figura 2.4: Densidade de procariotos (a) e densidade de células vivas (b) (média \pm erro padrão) na camada superficial $(0-1 \mathrm{~cm})$ do sedimento dentro do tempo experimental. (* $\mathrm{p}<0.05$, ANOVA, Tukey).

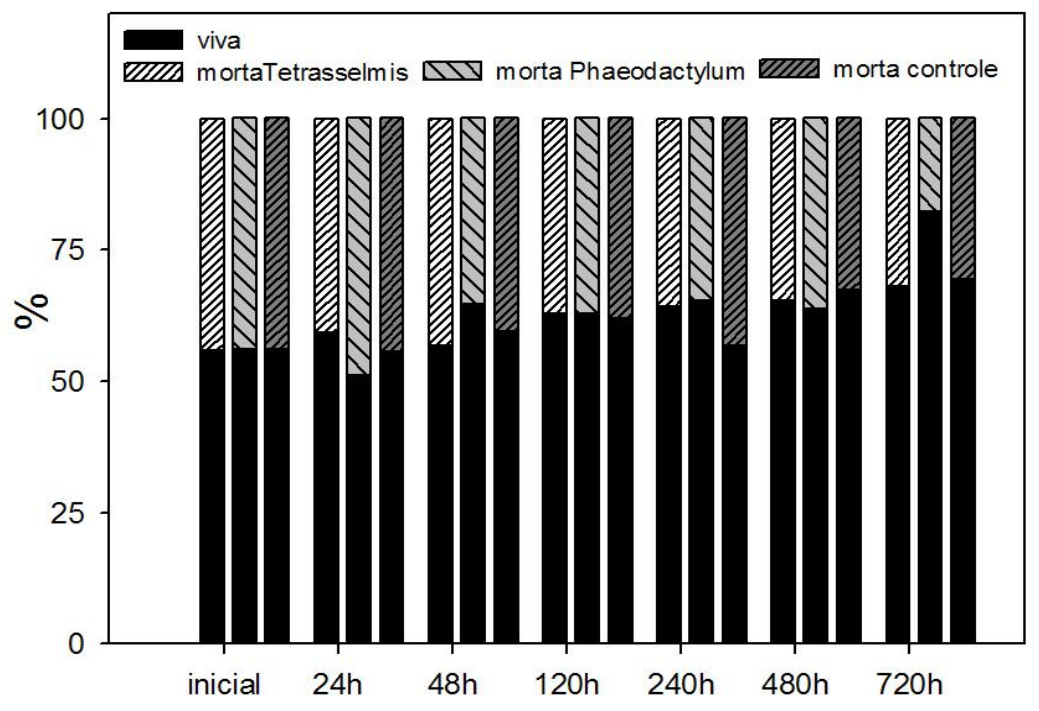

Figure 2.5: Porcentagem de células vivas e mortas pela coloração de Live/Dead na primeira camada $(0-1 \mathrm{~cm})$ do sedimento no tempo amostrado (horas).

Tabela 2.2: Análise estatística ANOVA dos valores de densidade total e de células vivas na camada superficial durante o tempo do experimento.

\begin{tabular}{|c|c|c|c|c|}
\hline & \multicolumn{2}{|c|}{ Densidade Total } & \multicolumn{2}{|c|}{ Densidade vivos } \\
\hline & $\mathrm{p}$ & Tukey $(\mathrm{p}<0.05)$ & $\mathrm{p}$ & Tukey $(\mathrm{p}<0.05)$ \\
\hline Tetrasselmis & 0,00 & $24 \mathrm{~h}, 48 \mathrm{~h}, 120 \mathrm{~h}, 240,480 \mathrm{~h} \neq 720 \mathrm{~h}$ & 0,07 & \\
\hline Phaeodactylum & 0,00 & $\begin{array}{l}24 \mathrm{~h}, 120 \mathrm{~h}, 240 ; 480 \mathrm{~h} \neq 720 \text {; initial, } \\
24 \mathrm{~h}, 480 \mathrm{~h} \neq 40 \mathrm{~h}\end{array}$ & 0,01 & $\begin{array}{l}\text { inicial, 24h, } \\
720 \mathrm{~h} \neq 48 \mathrm{~h}\end{array}$ \\
\hline Controle & 0,00 & inicial, $24 \mathrm{~h} \neq 120 \mathrm{~h}, 240 \mathrm{~h}, 480$ & 0,03 & $\begin{array}{l}\text { inicial, } 24 \mathrm{~h} \neq 120 \mathrm{~h} \text {, } \\
240 \mathrm{~h}\end{array}$ \\
\hline
\end{tabular}




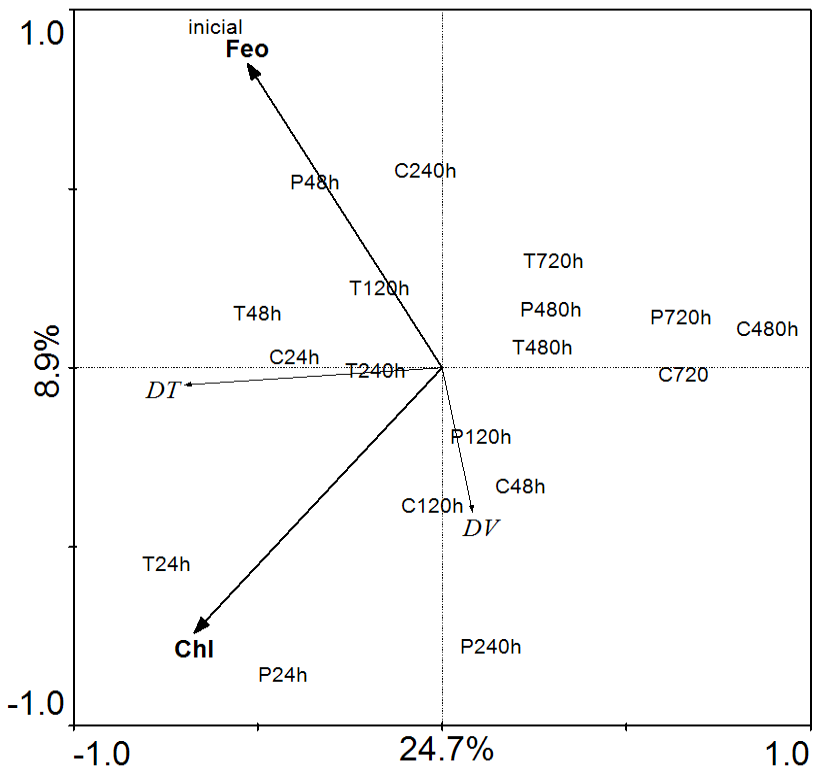

Figura 2.6: Análise de redundância (RDA) observando a influência das variáveis abióticas ( $\mathrm{n}=19,5$ variáveis) na densidade de procariotos $(\mathrm{n}=19,2$ variáveis). DT. Densidade total; DV. Densidade vivas; Chl. Clorofila; Feo. Feopigmentos; T. Tetrasselmis; P. Phaeodactylum; C. controle.

\subsubsection{DGGE e diversidade bacteriana}

A estrutura da comunidade de bactérias do sedimento foi comparada com base na análise de DGGE do gene 16S do rRNA. Os padrões de DGGE mostraram maiores modificações com relação ao tempo do que entre os tratamentos (Figura 2.7). Foram observadas entre 25 e 34 bandas nas amostras de sedimento. Enquanto que no controle um maior número de bandas foi encontrado nos primeiros dias de experimento diminuindo subsequentemente com o tempo, nos tratamentos o número de bandas aumentou com o tempo, com o tratamento Tetrasselmis apresentando números mais elevados do que o tratamento Phaeodactylum (Figura 2.8). A composição da comunidade pôde ser separada em seis grupos com mais de $70 \%$ de semelhança na análise de agrupamento UPGMA (Figura 2.9). O primeiro grupo foi composto do inicial, tratamentos e controle após 24 h, o segundo grupo incluiu os tratamentos após $48 \mathrm{~h}$, o terceiro grupo incluiu o controle 48 e $120 \mathrm{~h}$ e tratamentos $120 \mathrm{~h}$, e os grupos quarto, quinto e sexto agruparam todas as amostras com $240 \mathrm{~h}, 480 \mathrm{~h}$ e $720 \mathrm{~h}$, respectivamente (Figura 2.9).

A CCA dos dados do DGGE explicou apenas 33,2\% da variação nos primeiros dois eixos (Figura 2.10a). A CCA confirmou que o tempo foi mais importante na 
estruturação da comunidade do que os tratamentos. De acordo com a análise de Monte Carlo apenas a clorofila-a, feopigmentos e COT influenciaram significativamente a estrutura da comunidade bacteriana em geral. Para observar a influência de todas as variáveis na comunidade bacteriana, uma CCA com todas as variáveis foi aplicada e explicou 60,7\% da variação nos primeiros dois eixos (Figura 2.10b). Eixo 1 teve uma correlação negativa com todas as variáveis, exceto COT, e o eixo 2 foi negativamente correlacionado com a densidade procariótica, MOT, $\mathrm{O}_{2}$ e COT, e positivamente com feopigmentos e clorofila-a.

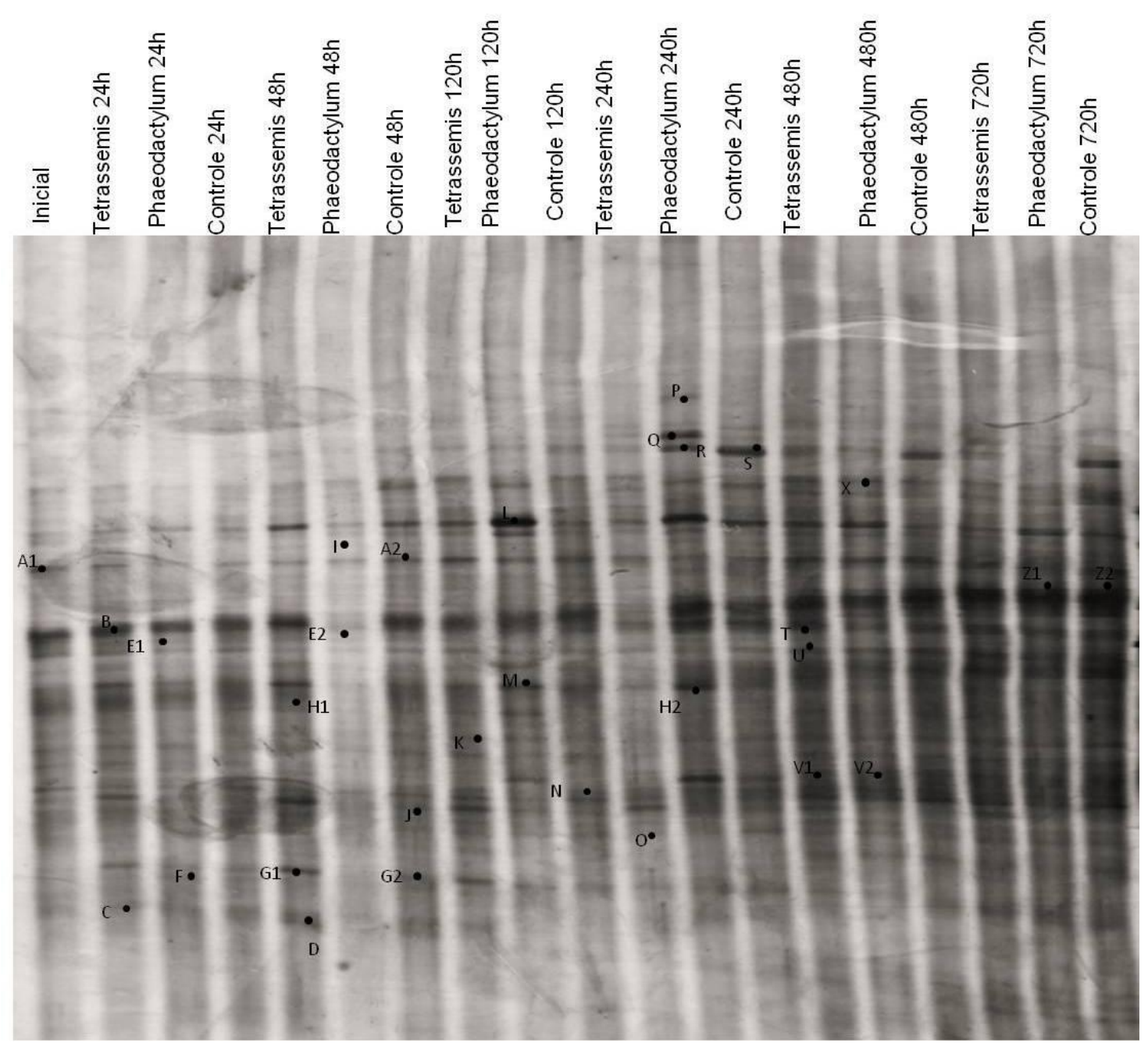

Figura 2.7: Estrutura da comunidade bacteriana representada em um gel de DGGE (gradiente 35-60\%) do gene 16S (338f-GC-518r) do DNA extraído da primeira camada do sedimento. Letras indicam as bandas cortadas e sequenciadas. 


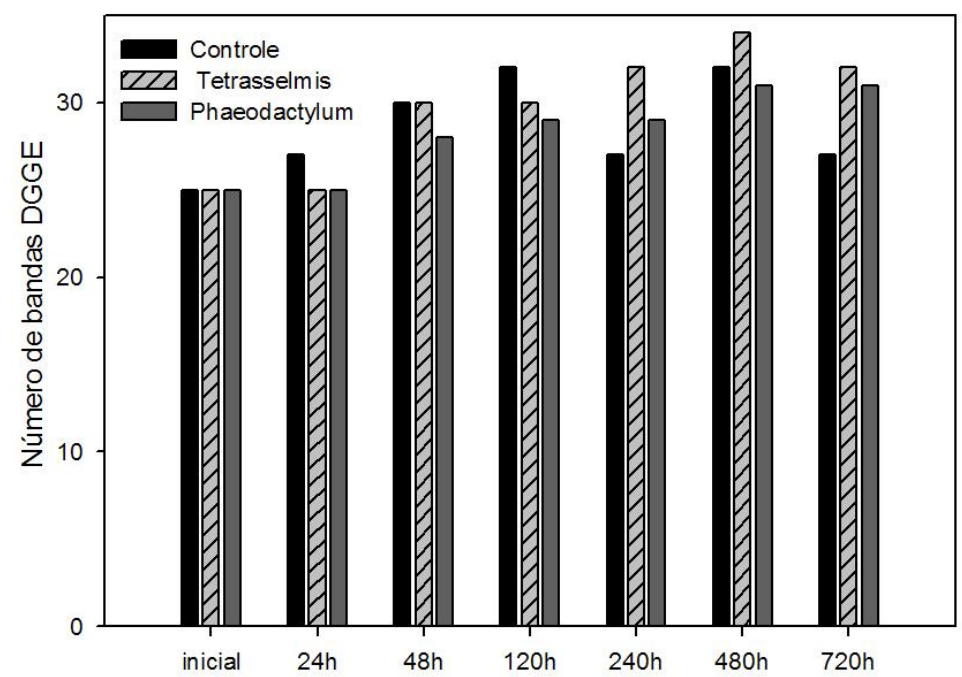
bacteriana.

Figura 2.8: Número de bandas identificadas no gel de DGGE da comunidade

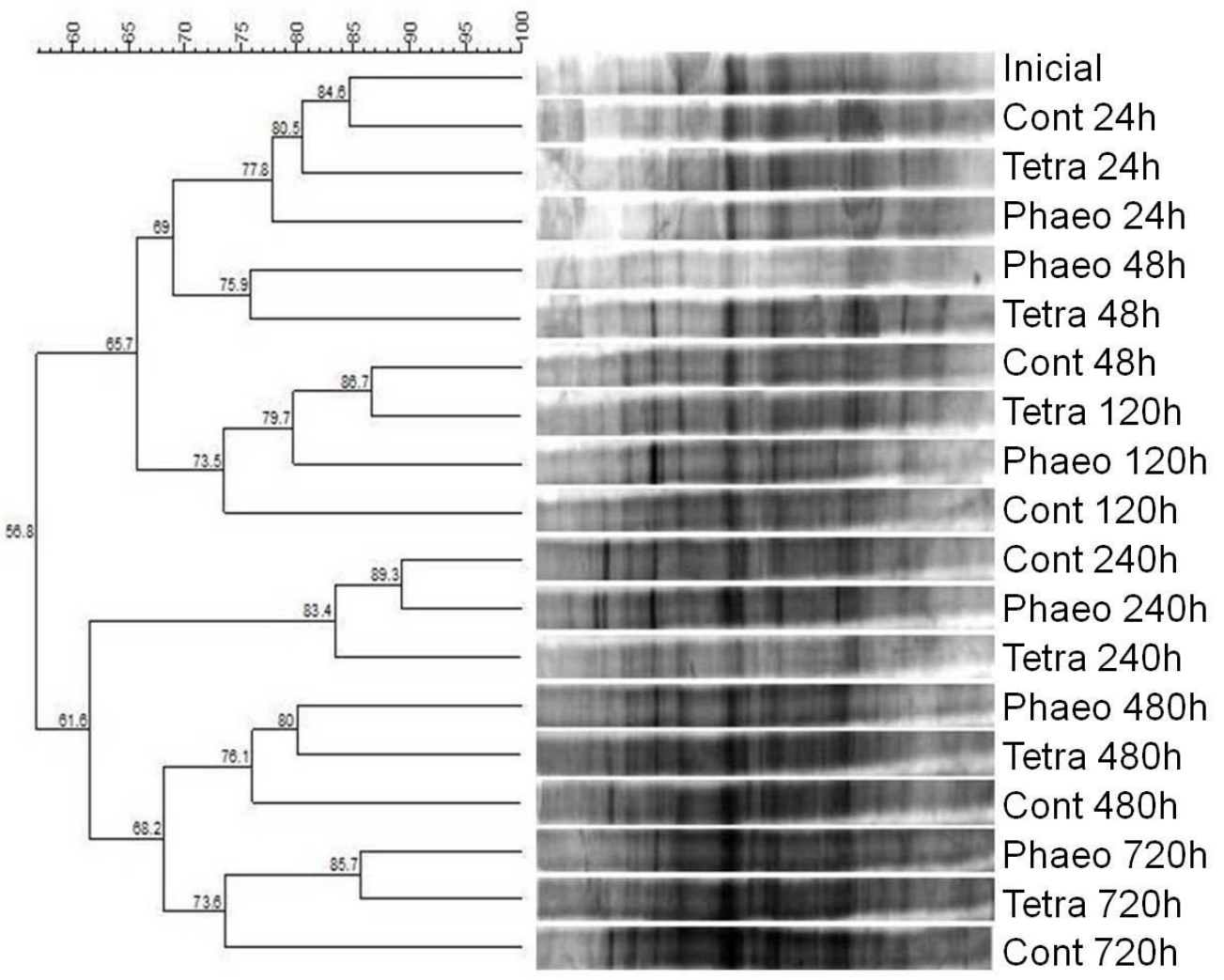

Figura 2.9: Análise de agrupamento do padrão de bandas de DGGE das bactérias sedimentares usando a análise UPGMA. Matrix de similaridade calculada usando DICE. 

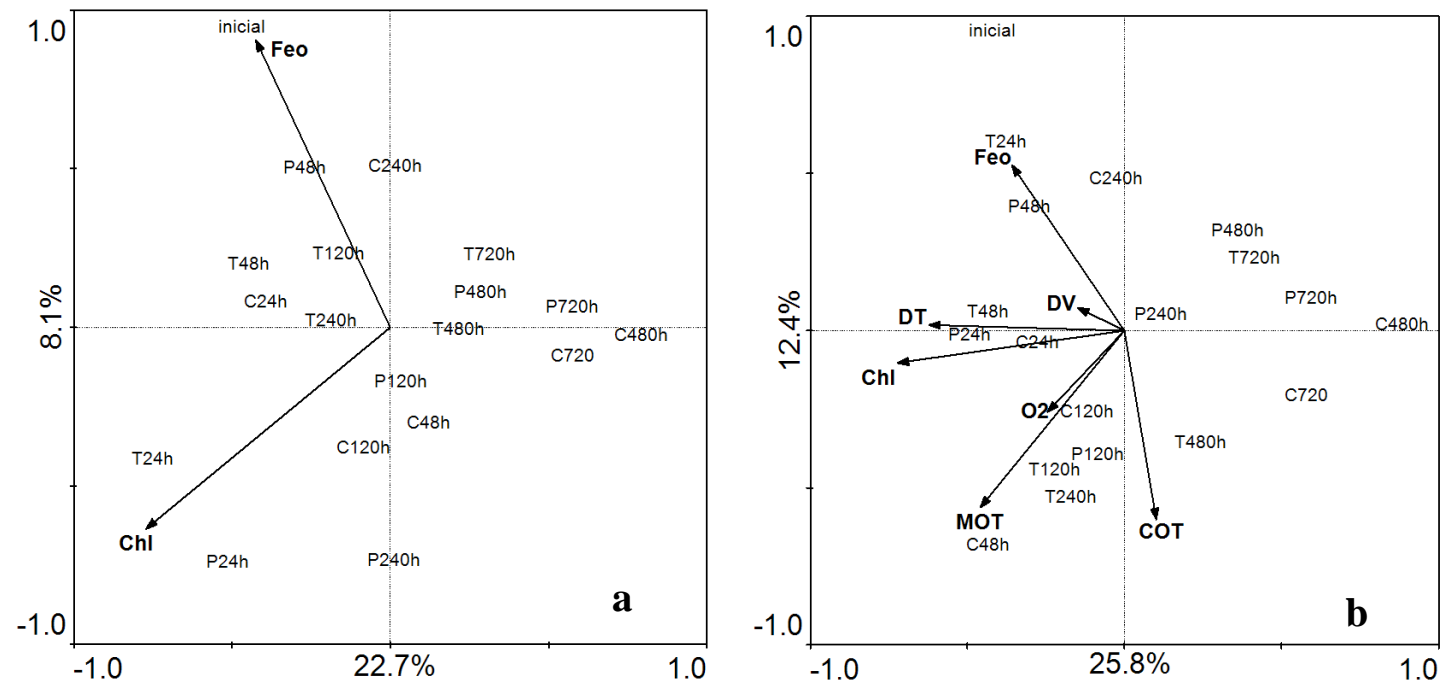

Figura 2.10: Análise de correspondência canônica (CCA) usando os perfis de PCR-DGGE das amostras do sedimento e as variáveis sedimentares medidas (clorofilaa, feopigmentos, MOT, COT, densidade total de procariotos e densidade de células vivas). a. CCA mostrando apenas as variáveis significativas de acordo com o teste de Monte Carlo $(\mathrm{p}<0.05)$ b. CCA mostrando a influência de todas as variáveis.

O sequenciamento parcial de 30 bandas excisadas a partir de perfis de DGGE foi determinado (Figura 2.7) e o mais próximo organismo relacionado no banco de dados foi determinado, apresentando semelhança superior a $80 \%$ com sequências conhecidas (Tabela 2.3). A maioria das bandas pôde ser atribuída à Gammaproteobacteria, seguido por alfa-, e Deltaproteobacteria, Firmicutes e Bacteroidetes (Tabela 2.3). Três bandas ocorreram em todas as amostras (A1, 2; B; G1, 2) e foram designadas como Bacteroidetes, Deltaproteobacteria e Gammaproteobacteria, respectivamente. Três bandas apareceram em quase todas as amostras ( $\mathrm{L}, \mathrm{M}$ e $\mathrm{X}$ ), bandas $\mathrm{L}$ e $\mathrm{M}$ foram Gammaproteobacteria e não ocorreram apenas nas amostras a partir de $480 \mathrm{~h}$, e em Phaeodactylum 720 h. Banda X foi atribuída como Deltaproteobacteria e não estava presente apenas em Phaeodactylum 24 h e no controle 120 h (Figura 2.7; Tabela 2.3). Duas bandas ( $\mathrm{C}$ e F) ocorreram somente nos primeiros dias do experimento e foram designadas como Gammaproteobacteria (Vibrionales e Oceanospirillales, respectivamente). 
Tabela 2.3: Afiliação filogenética dos genótipos detectados na primeira camada sedimentar das amostras experimentais sequenciadas a partir das bandas de DGGE.

\begin{tabular}{|c|c|c|c|c|c|}
\hline Amostra & $\begin{array}{l}\text { No. total de } \\
\text { bandas } \\
\text { detectadas }\end{array}$ & Banda & Afiliação filogenética & $\begin{array}{l}\% \\
\text { similaridade }\end{array}$ & Sequências com relação mais próxima e no. de acesso do GenBanK \\
\hline Inicial & $19 \_2$ & A1 & Bacteroidetes & $98 \%$ & Aestuariicola saemankumensis strain SMK-142 16S ribosomal RNA gene, partial \\
\hline Controle $48 \mathrm{~h}$ & & A2 & & & sequence.EU239499 \\
\hline Tetrasselmis $24 \mathrm{~h}$ & 19_1 & B & Deltaproteobacteria & $85 \%$ & Desulfotalea arctica strain LSv514 16S ribosomal RNA gene, partial sequence.AF099061 \\
\hline Tetrasselmis $24 \mathrm{~h}$ & $5 \_-1$ & $\mathrm{C}$ & Gammaproteobacteria & $97 \%$ & Vibrio ruber strain VR1 16S ribosomal RNA, partial sequence.NR_028837 \\
\hline Tetrasselmis $48 \mathrm{~h}$ & $6 \_1$ & $\mathrm{D}$ & Alphaproteobacteria & $97 \%$ & Roseobacter sp. TKW 16S ribosomal RNA gene, partial sequence.DQ479380 \\
\hline Phaeodactylum $24 \mathrm{~h}$ & $13 \_2$ & E1 & Gammaproteobacteria & $94 \%$ & Microbulhifor moritimus ctroin TE-17 16C ribocomol DNA aono nortiol coguonco 4 V277086 \\
\hline Phaeodactylum 48h & & E2 & & & Microbulbifer maritimus strain TF-17 16S ribosomal RNA gene, partial sequence.AY37/986 \\
\hline Phaeodactylum $24 \mathrm{~h}$ & 5_1 & $\mathrm{F}$ & Gammaproteobacteria & $77 \%$ & $\begin{array}{l}\text { Uncultured Alcanivorax sp. clone H02P24-42 16S ribosomal RNA gene, partial } \\
\text { sequence.HQ161398 }\end{array}$ \\
\hline $\begin{array}{l}\text { Tetrasselmis } 48 \mathrm{~h} \\
\text { Controle } 48 \mathrm{~h}\end{array}$ & $19 \_2$ & $\begin{array}{l}\text { G1 } \\
\text { G2 }\end{array}$ & Gammaproteobacteria & $95 \%$ & Ferrimonas kyonanensis gene for 16S rRNA, partial sequence.AB245514 \\
\hline $\begin{array}{l}\text { Tetrassemis } 48 \mathrm{~h} \\
\text { Phaeodactylum } 240 \mathrm{~h}\end{array}$ & 9_2 & $\begin{array}{l}\mathrm{H} 1 \\
\mathrm{H} 2\end{array}$ & Gammaproteobacteria & $81 \%$ & Thalassomonas agarivorans strain TMA1 16S ribosomal RNA gene, partial sequence \\
\hline Phaeodactylum $48 \mathrm{~h}$ & 11_1 & I & Bacteroidetes & $82 \%$ & Perexilibacter aurantiacus gene for 16S rRNA, partial sequence.AB276355 \\
\hline Controle $48 \mathrm{~h}$ & $11 \_1$ & $\mathrm{~J}$ & Alphaproteobacteria & $95 \%$ & Pseudoruegeria aquimaris strain SW-255 16S ribosomal RNA, partial sequence.DQ675021 \\
\hline Tetrasselmis $120 \mathrm{~h}$ & $11 \_1$ & $\mathrm{~K}$ & Alphaproteobacteria & $98 \%$ & Nautella italica partial 16S rRNA gene, type strain LMG 24365T. AM904562 \\
\hline Phaeodactylum $120 \mathrm{~h}$ & $15 \_1$ & $\mathrm{~L}$ & Gammaproteobacteria & $98 \%$ & Methylophaga aminosulfidovorans 16S ribosomal RNA gene, partial sequence.DQ463161 \\
\hline Phaeodactylum $120 \mathrm{~h}$ & $15 \_1$ & M & Gammaproteobacteria & $90 \%$ & Thiococcus pfennigii strain $425016 \mathrm{~S}$ ribosomal RNA, partial sequence.Y12373 \\
\hline Controle $120 \mathrm{~h}$ & 13_1 & $\mathrm{N}$ & unclassified Bacteria & $96 \%$ & $\begin{array}{l}\text { Uncultured soil bacterium isolate DGGE gel band } 2216 \text { S ribosomal RNA gene, partial } \\
\text { sequence.HM164438 }\end{array}$ \\
\hline Tetrasselmis $240 \mathrm{~h}$ & 9_1 & 0 & Alphaproteobacteria & $100 \%$ & Roseivivax halotolerans gene for 16S rRNA, strain: OCh 210.D85831 \\
\hline Phaeodactylum 240h & 3_1 & $\mathrm{P}$ & Firmicutes & $96 \%$ & Oceanobacillus iheyensis HTE831 gene for 16S ribosomal RNA, partial sequence.AB010863 \\
\hline Phaeodactylum $240 \mathrm{~h}$ & $6 \_1$ & Q & Gammaproteobacteria & $95 \%$ & Vibrio penaeicida 16S rRNA gene, strain DSM 14398T.AJ421444 \\
\hline Phaeodactylum $240 \mathrm{~h}$ & 9_1 & $\mathrm{R}$ & Gammaproteobacteria & $100 \%$ & Trabulsiella guamensis $16 \mathrm{~S}$ ribosomal RNA, partial sequence.AY373830 \\
\hline Controle $240 \mathrm{~h}$ & $4 \_1$ & $\mathrm{~S}$ & Bacteroidetes & $95 \%$ & Muricauda lutimaris strain SMK-108 16S ribosomal RNA gene, partial sequence.EU156065 \\
\hline Tetrasselmis $480 \mathrm{~h}$ & $3 \_1$ & $\mathrm{~T}$ & Gammaproteobacteria & $97 \%$ & Halochromatium salexigens partial 16S rRNA gene, type strain 6310T .X98597 \\
\hline Tetrasselmis $480 \mathrm{~h}$ & $9 \_1$ & $\mathrm{U}$ & Gammaproteobacteria & $86 \%$ & Methylophaga marina strain 222 16S ribosomal RNA, partial sequence. X95459 \\
\hline Tetrasselmis $480 \mathrm{~h}$ & 8_2 & V1 & Firmicutes & $87 \%$ & Sedimentibacter saalensis ZF2 $16 \mathrm{~S}$ rRNA gene.AJ404680 \\
\hline Phaeodactylum $480 \mathrm{~h}$ & & V2 & & & \\
\hline Phaeodactylum 480h & $16 \_1$ & $\mathrm{X}$ & Deltaproteobacteria & $84 \%$ & Desulfovibrio bizertensis strain MB3 16S ribosomal RNA gene, partial sequence.DQ422859 \\
\hline Tetrasselims $720 \mathrm{~h}$ & $3 \_-2$ & $\mathrm{Z1}$ & Gammaproteobacteria & $81 \%$ & Thiorhodococcus minor partial 16S rRNA gene, strain CE2203.Y11316 \\
\hline Phaeodactylum $720 \mathrm{~h}$ & & $\mathrm{Z2}$ & & & \\
\hline
\end{tabular}




\subsection{Discussão}

\subsubsection{Parâmetros abióticos}

Florescimentos de fitoplâncton são comuns em muitas áreas costeiras e podem fornecer entradas maciças de matéria orgânica em sedimentos costeiros, desencadeando uma resposta dinâmica da comunidade microbiana. Estudos experimentais têm examinado a resposta da comunidade bacteriana ao enriquecimento da coluna d'água (Pinhassi et al., 1999; Riemann et al., 2000; Fandino et al., 2001). Porém, em sedimentos poucos estudos mostraram a resposta da comunidade a estes acontecimentos (Enockson, 1993; Franco et al., 2007). O objetivo principal deste estudo foi comprovar experimentalmente a estimulação dos micro-organismos sedimentares após o aporte de matéria orgânica lábil e observar as mudanças da comunidade quando diferentes florescimentos algais ocorrem.

$\mathrm{O}$ enriquecimento do sedimento estimula o consumo de oxigênio em comparação com testemunhos sem algas. Isto está de acordo com as descobertas de outros experimentos e em estudos in situ (Jensen et al., 1990; Enockson, 1993; Cook et al., 2007). A respiração e a redução de sulfato são geralmente consideradas como as principais vias de degradação da matéria orgânica em sedimentos costeiros (Canfield et al., 2005). Portanto, os nossos resultados sugerem uma maior degradação nos tratamentos com a adição de algas.

A variação de parâmetros sedimentares indicou o consumo da matéria orgânica particulada que foi adicionada no sedimento. O pico de clorofila-a depois de 24 horas é provavelmente o resultado da adição de algas. A diminuição significativa de clorofila após este período sugere o rápido consumo pela comunidade bêntica sedimentar. Kristensen \& Holmer (2001) apontaram que as partículas orgânicas mais lábeis presentes em sedimentos marinhos são rapidamente consumidas, em geral durante as primeiras seis semanas após chegarem ao sedimento. Chipman et al. (2010) mostraram que a matéria orgânica dissolvida derivada do plâncton possui uma meia-vida de 10 a 16 h em sedimentos costeiros.

Nossos dados de COT e MOT mostram um aumento nos valores até 120 horas após a adição. É bem conhecido que a matéria orgânica dissolvida (MOD) é uma das principais fontes de carbono orgânico no planeta e é um substrato importante para o crescimento bacteriano em ecossistemas aquáticos (Azam et al., 1993). As bactérias presentes no sedimento rapidamente consomem a MOD, transformando em $\mathrm{CO}_{2}$ e 
biomassa (MOP). Uma vez que estamos trabalhando em um sistema fechado, a matéria orgânica presente no sedimento não é perdida, mas transformada, e mantendo assim os seus valores sem grandes variações durante o experimento.

\subsubsection{Resposta microbiana}

As comunidades microbianas podem responder a um número variado de fontes de substratos quer por adaptação fisiológica e/ou por alterações na composição da comunidade. Mesmo pequenas adições de substratos orgânicos podem desencadear mudanças na composição da comunidade microbiana, acompanhadas de mudanças na eficiência de crescimento das comunidades (Del Giorgio \& Cole, 2000).

A fração dos procariotos vivos obtidos neste estudo (52-82\%) são semelhantes aos valores encontrados nos sedimentos onde a coloração Live/Dead foi aplicada (Quéric et al., 2004; Haglund et al., 2003), porém maiores do que os encontrados em métodos onde se mediu a fração ativa da comunidade (Luna et al., 2002; Haglund et al., 2002). Uma vez que as bactérias dormentes com as membranas intactas são incluídas na fração de vivas, não é surpreendente o método vivo/morto encontrar uma maior porção de bactérias do que a medida de bactérias ativas.

Após a adição das algas foi observado um aumento na densidade (procariótica total) e no metabolismo (procariotos vivos associados a um maior consumo de $\mathrm{O}_{2}$ ) da comunidade microbiana. Este aumento no número e no metabolismo foi acompanhado por uma diminuição na clorofila-a, a qual mostrou uma relação significativa com a densidade procariótica. Assim, acreditamos que os micro-organismos responderam ao estímulo, consumindo MO lábil (microalgas) logo após a sua chegada à superfície do sedimento. A resposta microbiana ao enriquecimento orgânico do sedimento foi demonstrada por vários estudos que mostram que a comunidade responde quase que imediatamente à chegada de alimentos com um respectivo aumento de biomassa, densidade e atividade da microbiota (Meyer-Reil, 1983; Lavigne et al., 1997; Danovaro et al., 1999; Rusch et al., 2003; Polymenakou et al., 2007). O tratamento Tetrasselmis mostrou uma resposta mais rápida do que o realizado com Phaeodactylum. De acordo com Aidar et al. (1993), os fitoflagelados de Ubatuba apresentam uma maior concentração de clorofila em comparação com as diatomáceas, o que sugere que tais organismos produzem MO de melhor qualidade (Aidar et al., 1993; Gaeta et al., 1999). 
Adicionalmente, diatomáceas possuem tecas silicosas, o que dificulta a ação microbiana (Hansen \& Josefson, 2003).

Como com qualquer técnica baseada em análises de PCR e DNA, a técnica de DGGE dos amplificados de 16S rRNA tem as suas próprias limitações metodológicas (Muyzer et al., 1993). Contudo, a análise do 16S mediada por PCR ainda é uma ferramenta poderosa para a determinação da diversidade microbiana em ecossistemas (von Wintzingerode et al., 1997). Técnicas de DGGE são bastante eficazes na caracterização da estrutura da comunidade bacteriana, especialmente para monitorar mudanças na ocorrência e/ou frequência relativa das diferentes populações (Fromin et al., 2002).

Foi suposto que a deposição de fitodetritos, composta principalmente de diatomáceas ou fitoflagelados, pode ter diferentes implicações na degradação da matéria orgânica e levar a diferentes respostas da comunidade bacteriana, tanto em composição quanto na velocidade de resposta das populações específicas de micro-organismos do sedimento. Vários estudos já demonstraram que a composição da comunidade bacteriana varia com as espécies de algas e seu estado fisiológico na coluna de água (e.g. Schäfer et al., 2002; Grossart et al., 2005). A análise inicial da comunidade bacteriana pela técnica de DGGE demonstrou que, em geral, o tempo foi mais importante em alterar a comunidade do que os tratamentos. Na análise de agrupamento, maiores diferenças da comunidade microbiana foram encontradas entre tratamentos e controle logo após a adição das algas (24 e 48 h). Entre o total de bandas observadas, $10 \%$ ocorreram apenas nos tratamentos, sendo observadas principalmente nos primeiros dias após a adição das algas. Enquanto apenas 3\% das bandas foram observadas apenas no controle. O tratamento com Phaeodactylum levou a maior mudança na comunidade, com 5\% das bandas ocorrendo exclusivamente com esse tratamento, enquanto nenhuma banda ocorreu apenas quando Tetrasselmis foi adicionada.

No sistema planctônico, mudanças na abundância das espécies do fitoplâncton são responsáveis por mudanças na composição da comunidade bacteriana adjacente (Rooney-Varga et al., 2005). Além disso, mudanças na qualidade e quantidade da matéria orgânica podem induzir alterações na estrutura da comunidade bacteriana (Luna et al., 2004). Esta relação é corroborada pela relação observada entre a composição da comunidade bacteriana e a concentração de clorofila-a do sedimento. Em geral, a abundância bacteriana e as taxas dos processos observados seguiram flutuações na concentração de clorofila-a em uma magnitude similar à encontrada em outros estudos, 
tanto in situ, quanto em experimentos em mesocosmos (Karner \& Herndl, 1992; Middelboe et al., 1995; Smith et al., 1995; Franco et al., 2007).

Gammaproteobacteria foi o filo dominante nas amostras de sedimento sequenciadas, representando $50 \%$ das sequências. Este achado é consistente com estudos anteriores que mostraram que Gammaproteobacteria tem sido frequentemente detectada em sedimentos marinhos e muitas vezes representaram a maior proporção de clones de bibliotecas nestes ambientes (Ravenschlag et al., 2001; Zeng et al., 2005; Lai et al., 2006). Por ser versátil metabolicamente, este filo é ecologicamente muito bem sucedido (Madigan et al., 1997) e parece ter a capacidade de responder rapidamente às adições de nutrientes. Em estudos de coluna de água, sugeriu-se que este grupo tem uma vantagem competitiva inicial quando a MOD de exsudados de diatomáceas estão disponíveis (Puddu et al., 2003; Pete et al., 2010). Gihring et al. (2009) e Chipman et al. (2010) observaram que Gammaproteobacteria são as bactérias mais ativas envolvidas na degradação da MOP fresca em sedimentos permeáveis e parece ser um dos grupos mais importantes associados à degradação do carbono derivado do plâncton nos sedimentos marinhos (Rusch et al., 2003; Mills et al., 2008).

O segundo grupo representativo nas bandas sequenciadas foi o grupo Rhodobacteriaceae das Alphaproteobacteria. Membros da Alphaproteobacteria foram previamente identificados em amostras de sedimentos marinhos (Obernosterer et al., 2009; Ikenaga et al., 2010;. Du et al., 2011; Kan et al., 2011). Na coluna de água, os membros deste grupo são altamente associados a eventos de florescimento de fitoplâncton e frequentemente associados à colonização e hidrólise de partículas (Riemann et al., 2000; Fandino et al., 2001; Grossart et al., 2005;. Rink et al., 2007). Bacteroidetes são também encontrados em amostras de sedimento e parecem ser um grupo importante na degradação do carbono derivado de fitoplâncton nos sedimentos (Rusch et al., 2003; Lai et al., 2006; Mills et al., 2008). Os Bacteroidetes também desempenham um papel importante no ciclo do carbono de substâncias orgânicas depositadas no sedimento em águas profundas (Rosselló-Mora et al., 1999; O'Sullivan et al., 2002). Este clado também tem sido encontrado em agregados marinhos e é conhecido pela sua capacidade de associar-se a superfícies orgânicas e degradar uma ampla variedade de substâncias poliméricas (Kirchman, 2002; Grossart et al., 2005; Bauer et al., 2006; Rink et al., 2007). Durante florescimentos fitoplanctônicos, membros de Bacteroidetes e Alphaproteobacteria são os grupos mais responsivos às mudanças na composição da matéria orgânica na coluna de água e também a alterações na 
composição do fitoplâncton (Riemann et al., 2000;. Fandino et al., 2001; Grossart et al., 2005; Rink et al., 2007). No presente estudo, os membros destes dois grupos foram encontrados principalmente durante os últimos dias após a adição de algas. Os membros destes grupos também são hábeis em utilizar macromoléculas mais complexas e exsudados de algas (Rooney-Varga et al., 2005; Pete et al., 2010).

Deltaproteobacteria e Firmutes também foram observadas na comunidade do sedimento. Deltaproteobacteria tem sido sugerida como uma linhagem bacteriana representativa em ambientes bênticos, sendo o grupo predominante nos sedimentos marinhos (Feng et al., 2009; Pachiadaki et al., 2010; Du et al., 2011). No presente estudo foram sequenciadas apenas duas bandas pertencentes a este grupo. Porém, as bandas foram observadas em quase todas as amostras de sedimento e com uma intensidade elevada. A maioria das Deltaproteobacteria é redutora de sulfato, um dos percursos de metabolismo mais importantes nos sedimentos marinhos que ocorrem em condições anaeróbicas (López-García et al., 2003; Ravenschlag et al., 2000). Apenas a primeira fatia do sedimento foi analisada, que compreendeu a camada óxica do sedimento, o que explica a baixa diversidade desse grupo. Firmicutes também foi observada nas bandas sequenciadas. Este é um grupo importante de bactérias grampositivas e tem sido frequentemente encontrado em sedimentos anóxicos (Urakawa et al., 1999; Köcklin et al., 2011).

Este estudo demonstrou que a chegada de material derivado de fitoplâncton marinho ao sedimento leva a uma rápida resposta da comunidade microbiana, tanto numérica quanto metabolicamente. Estes resultados confirmam a hipótese de que a quantidade e a qualidade da matéria orgânica são fatores importantes que estruturam a comunidade microbiana em sedimentos marinhos. Diferentes organismos planctônicos podem levar a diferentes respostas da comunidade do sedimento. Neste estudo, foi observada uma resposta mais rápida da comunidade microbiana quando fitoflagelados foram adicionados ao sedimento ( 24 h após a adição), mas a resposta observada com a adição de diatomáceas parece ser mais proeminente. A adição das algas parece também ter causado a mudanças na estrutura da comunidade, levando a diferenças entre tratamentos e controle logo após a adição. Porém, o tempo após a adição das algas é mais importante para estruturar a composição da comunidade do que o tipo de algas adicionado. 


\section{Capítulo 3: Influência do enriquecimento orgânico na distribuição vertical dos micro-organismos na coluna sedimentar marinha costeira}

\subsection{Introdução}

Os sedimentos marinhos são ambientes estratificados verticalmente, como um resultado da disponibilidade de doadores de elétrons e processos de respiração (Fenchel \& Finlay, 1995). Os sedimentos marinhos sublitorais estão em contato constante com a água sobrejacente, compartilhando características e nutrientes, através dos fluxos de água no interior do sedimento. A concentração de oxigênio presente é limitada pela sua baixa solubilidade na água intersticial. Desta forma, quando a matéria orgânica está presente, a oxidação aeróbica ocorre em altas taxas na superfície do sedimento, porém, após poucos centímetros de profundidade, sedimentos não perturbados tornam-se quase que universalmente anóxicos (Nealson, 1997). Isto gera uma série de gradientes horizontais estáveis, nos quais vários aceptores de elétrons são consumidos, usualmente na ordem de diminuição do potencial redox (i.e. de acordo com a habilidade de cada aceptor de elétrons de receber elétrons). Abaixo da fina camada óxica superficial, ocorre a chamada zona sub-óxica, na qual o nitrato, manganês e ferro oxidados $\left(\mathrm{NO}_{3}{ }^{-}, \mathrm{Mn}^{4+} \mathrm{e}\right.$

$\mathrm{Fe}^{3+}$ ) são os principais aceptores de elétrons. Logo abaixo ocorre a zona reduzida, a qual é caracterizada por compostos de sulfeto produzidos por bactérias redutoras de sulfato (Kristensen, 2000). Essa gradiente vertical de propriedades biogeoquímicas providencia nichos para uma diversidade de micro-organismos com diferentes padrões metabólicos.

Em sedimentos marinhos, genes 16S rRNA microbianos, representativos de diferentes funções metabólicas mostram claro padrão de mudança com a profundidade (Braker et al., 2001; Stach et al., 2003; Mußmann et al., 2005). Parâmetros ambientais, tais como, impacto de ondas (Hewson \& Fuhrman, 2006), quantidade de carbono orgânico e clorofila-a (Polymenakou et al., 2005a, 2007), tipo de sedimento (Franco et al., 2007), conteúdo de água (Hewson et al., 2007) e enriquecimento com nutrientes inorgânicos (Hewson et al., 2003), têm sido correlacionados a variações na estrutura da comunidade bacteriana bêntica.

As altas deposições de matéria orgânica em sistemas costeiros promovem rápidos processos diagenéticos na interface sedimento-água, que afeta os ciclos 
biogeoquímicos do carbono, assim como a distribuição de nutrientes e elementos químicos nos sedimentos costeiros (Hedges and Keil, 1995). Entretanto, estudos observando possíveis mudanças na composição e diversidade da comunidade microbiana após massivos inputs de matéria orgânica ainda são poucos (Franco et al., 2007), e estudos observando a influência de matéria orgânica derivada de diferentes organismos planctônicos na distribuição vertical dos micro-organismos são inexistentes.

Dessa forma, o presente estudo visou observar as mudanças na distribuição vertical microbiana do sedimento após a adição de matéria orgânica particulada derivada da produção fitoplanctônica de duas diferentes microalgas (diatomácea e fitoflagelado) em um estudo experimental onde as variáveis ambientais foram controladas. Para tanto, um experimento laboratorial foi realizado em Nov/Dez de 2009 onde as características sedimentares e a densidade e diversidade bacteriana foram monitoradas por um total de 30 dias após a adição das algas a superfície do sedimento.

\subsection{Material e Métodos}

\subsection{1. Área de estudo}

A plataforma interna ao Largo de Ubatuba é dominada por águas costeiras quentes $\left(\mathrm{T}>25^{\circ} \mathrm{C}\right)$ e com baixas salinidades (32-33) (Castro Filho et al., 1987). O regime da região é classificado como mesotrófico, com baixa produtividade primária, devido principalmente à baixa contribuição de aportes de origem terrestre e pela limitação de compostos inorgânicos de nitrogênio e fósforo (Gaeta et al., 1999). A produção primária e os padrões de sedimentação são principalmente influenciados pela interação sazonal de três massas de água, a Água Costeira (AC), a Água Tropical (AT) e Água Central do Atlântico Sul (ACAS) (Castro-Filho et al., 1987). A ACAS exerce grande influência sobre a área principalmente no verão, quando atinge o limite interno da Plataforma Continental Sudeste (10 a 50m de profundidade). Desta forma, promove o input de nutrientes para a zona fótica aumentando a produtividade primária local, e propiciando a ocorrência de florescimentos fitoplanctônicos, principalmente diatomáceas (Gaeta et al., 1995), assim como a deposição da matéria orgânica (Silveira et al., 2000). De acordo com Mahiques et al. (2004), a complexa dinâmica das massas de água também controla os processos de sedimentação em toda a margem continental sudeste brasileira. Isso gera uma complexa distribuição de sedimentos, que se apresenta em manchas de tamanho de grão distinta e teor de matéria orgânica. 


\subsubsection{Amostragem e montagem experimental}

As amostras foram coletadas na região de Ubatuba, costa norte do estado de São Paulo, na plataforma sudeste brasileira $\left(23^{\circ} 36.679\right.$ 'S $-44^{\circ} 58.598^{\prime} \mathrm{W}$ e $40 \mathrm{~m}$ de profundidade). Os testemunhos foram coletados com um mini-multicorer e fatiado a bordo em quatro profundidades $(0-2,2-5,5-10,10-20 \mathrm{~cm})$. O sedimento de todos os testemunhos de cada camada foram homogeneizados, peneirados em peneira de $1 \mathrm{~mm}$ e remontado em testemunhos de acrílico com $10 \mathrm{~cm}$ de diâmetro e $20 \mathrm{~cm}$ de coluna sedimentar. Um total de 57 testemunhos foi mantido em três sistemas separados (dois tratamentos e um controle) sem luz e com oxigenação e circulação em uma sala de temperatura controlada $\left(19^{\circ} \mathrm{C}\right)$. Foi escolhido o fitoflagelado Tetrasselmis sp. e a diatomácea Phaeodactylum tricornutum para a adição experimental, por serem espécies comuns ocorrendo na área de estudo e estarem disponível no banco de algas do IOUSP. Antes da adição das algas a clorofila-a das culturas foi quantificada e foi adicionada uma quantidade de clorofila-a cinco vezes superior ao máximo de clorofila encontrado na região (2,77 $\mathrm{mg} \mathrm{ml}^{-1}$; Aidar et al., 1993).

Após cinco dias de aclimatação três testemunhos foram tomados para as análises iniciais $(\mathrm{t}=0)$ e as microalgas foram adicionadas à superfície do sedimento. $\mathrm{O}$ experimento foi mantido por um total de 30 dias após a introdução das algas. Amostragens foram realizadas seis vezes nesse período ( $\mathrm{t}=24 \mathrm{~h}, 48 \mathrm{~h}, 120 \mathrm{~h}, 240 \mathrm{~h}, 480 \mathrm{~h}$, 720 h após a adição), durante o qual foram analisados três testemunhos de cada tratamento e do controle. Após um período de incubação para coleta de água para análises de fluxos sedimento-água o sedimento foi fatiado em 10 camadas de profundidade $(0-1,1-2,2-3,3-4,4-5,5-8,8-11,11-14,14-17,17-20 \mathrm{~cm})$ e amostrado para as diversas análises sedimentares.

\subsubsection{Características sedimentares}

As amostras de todas as camadas sedimentares foram analisadas quanto a clorofila a, feopigmentos e matéria orgânica total. A matéria orgânica total (MOT) foi obtida através do método de calcinação em forno mufla $\left(550^{\circ} \mathrm{C}\right)$ for 2,5-3h (Byers et al., 1978). Fitopigmentos foram extraídos com acetona $100 \%$ for $24 \mathrm{~h}$ a $-10^{\circ} \mathrm{C}$ e a absorbância foi medida (665 e 750nm) antes e após acidificação com 0,1 N HCl através 
de um espectrofotômetro (Plante-Cuny, 1978). As concentrações de clorofila-a e feopigmentos foram calculadas aplicando-se a fórmula sugerida por Lorenzen (1967).

\subsubsection{Comunidade microbiana}

Para as análises da comunidade microbiana três camadas sedimentares foram selecionadas, além da superficial, a camada subsuperficial (1-2 cm), uma camada intermediária (4-5 cm), e uma camada profunda $(14-17 \mathrm{~cm})$.

De cada réplica de sedimento amostrada, $1 \mathrm{ml}$ de sedimento foi retirado com seringa estéril e alocado em potes de plástico com $9 \mathrm{ml}$ de formol salino $2 \%$ pré-filtrado em filtro $0,2 \mu \mathrm{m}$. A densidade de procariotos foi determinada através de método de contagem direta em microscópio de epifluorescência, usando um kit de viabilidade Live/Dead (L/D) BacLight (L-7012, Molecular Probes, Eugene, OR; Quéric et al., 2004). As amostras foram diluídas 10.000 vezes após um período de agitação de 15 min. Dois mililitros das amostras diluídas foram coradas com $3 \mu \mathrm{l}$ de 1:1 dos corantes (6.68 M SYTO 9 e $20 \mathrm{M}$ iodeto propídico) e incubadas por $30 \mathrm{~min}$. em temperatura ambiente. A amostra foi filtrada em filtro policarbonato black de $0,2 \mu \mathrm{m}$ e montada em lâmina. Um total de 400 células por amostra foi contado em microscópio de epifluorescência.

A extração de DNA das amostras de sedimento foi realizada utilizando o PowerSoil DNA Isolation Kit (MoBio Laboratoires, CA, USA) de acordo com as especificações do fabricante. O DNA extraído foi quantificado e sua pureza checada através de medidas de absorbância com espectrofotômetro.

A região variável V3 do gene $16 \mathrm{~S}$ do rRNA foi amplificada do DNA extraído usando os primers 338f-GC e 518r para bactéria. A mistura para as reações de PCR em um total de $50 \mu \mathrm{l}$ consistiu de: $2 \mu \mathrm{l}$ de DNA extraído (aproximadamente $20 \mathrm{ng}$ ), $5 \mu \mathrm{l}$ 10X PCR Buffer (Invitrogen), 1,5 $\mu \mathrm{l} \mathrm{MgCl}_{2}$ (50mM), 0,4 $\mu \mathrm{l} \mathrm{dNTP}(100 \mathrm{mM}), 1 \mathrm{U}$ Taq polymerase (Platinum, Invitrogen), água livre de ácido nucléico até completar o volume. O PCR foi realizado através de um termociclador (Eppendorf Mastercycler Personal), nas seguintes condições: $94^{\circ} \mathrm{C}$ por $5 \mathrm{~min}$. seguido por 30 ciclos de $94^{\circ} \mathrm{C}$ por $1 \mathrm{~min}$., $55^{\circ} \mathrm{C}$ por 1 min., e $72^{\circ} \mathrm{C}$ por 2 min., com uma extensão do passo final a $72^{\circ} \mathrm{C}$ por 10 min. Todos os produtos finais de PCR foram checados e quantificados por eletroforese em gel de agarose $1 \%(\mathrm{w} / \mathrm{v})$. 
As análises de DGGE foram divididas entre as camadas sedimentares e, para observar a influência dos tratamentos na distribuição vertical, um DGGE adicional foi realizado com as amostras dos tratamentos após $24 \mathrm{~h}$ e $48 \mathrm{~h}$ da adição das algas e as amostras iniciais antes da adição. $\mathrm{Na}$ análise de DGGE, foi utilizado um gel de poliacrilamida a 8\%, com uma gradiente de denaturação de 30-70\% (100\% denaturante 7M ureia, e $40 \%$ formamida). Concentrações similares de produto de PCR foram colocadas no gel e a eletroforese foi realizada em tampão TAE $1 \mathrm{X}$ por $16 \mathrm{~h}$ a uma constante de $60 \mathrm{~V}$ a $60{ }^{\circ} \mathrm{C}$, utilizando o sistema Dcode Universal Mutation Detection System (Bio-Rad Laboratories, Richmond Calif.). O gel foi corado com nitrato de prata modificado de Sanguinetti et al. (1994) e a imagem obtida com o auxílio de um escâner.

\subsubsection{Análises estatísticas}

As relações entre a distribuição vertical das variáveis sedimentares medidas foram testadas através do teste de correlação de Pearson $(n=95)$. Foi realizada uma Análise de Componentes Principais (PCA; Canoco 4.5; Ter Braak \& Smilauer, 2002) para avaliar o padrão de distribuição das variáveis medidas nas amostras. O DGGE foi analisado através do programa BioNumerics 6.1 (AppliedMaths). Os dendogramas foram construídos através do coeficiente de similaridade de Dice e pela análise de agrupamento pelo método da distância média não ponderada (UPGMA). Com o objetivo de estabelecer qual variável melhor explicou o perfil de bandas do DGGE, Análises de Correspondência Canônica (CCA, CANOCO 4.5) foram realizadas.

\subsection{Resultados}

\subsubsection{Variáveis abióticas}

Os padrões dos perfis de clorofila-a na coluna sedimentar foram diferentes dependendo do tempo em que foi feita a coleta. Porém, de um modo geral os valores aumentaram nas camadas mais profundas do sedimento (Figura 3.1). No tempo de 24 horas após a adição das algas foram observados maiores valores na camada superficial do sedimento $(0-1 \mathrm{~cm})$ em ambos os tratamentos e controle, e uma diminuição com o aumento da profundidade da coluna sedimentar até $5 \mathrm{~cm}$ (Figura 3.1). Esse padrão se manteve nos valores com o tratamento Tetrasselmis no tempo de 48 horas. Já o tratamento com diatomácea e o controle apresentaram uma diminuição dos valores de clorofila na camada superficial e um pico na segunda camada da coluna sedimentar (1-2 
cm). Após $120 \mathrm{~h}$ da adição das algas foi observado um pico na segunda camada da coluna sedimentar em ambos os tratamentos, porém não no controle, que apresentou um pico na quinta camada $(4-5 \mathrm{~cm})$, também observado no tratamento com diatomácea (Figura 3.1). Nos tempos de 240 h, 480 h e 720 h após a adição algal foram novamente observados maiores valores na camada superficial do sedimento e diminuição com o aumento da profundidade da coluna sedimentar até $5 \mathrm{~cm}$, seguido de maiores valores nas camadas mais profundas do sedimento (Figura 3.1).

Os perfis de feopigmentos apresentaram padrões similares nos tratamentos e controle na maior parte dos tempos amostrados (Figura 3.2). Em ambos os tratamentos, após 24 h da adição algal, foi observado um pico subsuperficial $(1-2 \mathrm{~cm})$ seguido de um declínio nos valores até os $4 \mathrm{~cm}$ da coluna sedimentar e logo após um forte aumento nos valores de feopigmentos nos $6 \mathrm{~cm}$ de profundidade seguido novamente de declínio (Figura 3.2). Nas amostras subsequentes até 240 h após a adição das algas, os valores diminuíram com o aumento da profundidade até $5 \mathrm{~cm}$ e apresentando altos valores nas camadas mais profundas do sedimento (Figura 3.2). Esse padrão mudou após $480 \mathrm{~h}$ do tratamento, quando a coluna sedimentar tornou-se mais homogênea em relação aos feopigmentos (Figura 3.2).

O padrão de distribuição da matéria orgânica na coluna sedimentar (até $20 \mathrm{~cm}$ ) permaneceu constante nos tempos amostrados (Figura 3.3). Foi observado um aumento gradativo dos valores de MOT com o aumento na profundidade do sedimento, principalmente após $120 \mathrm{~h}$ de experimento (Figura 3.3). 

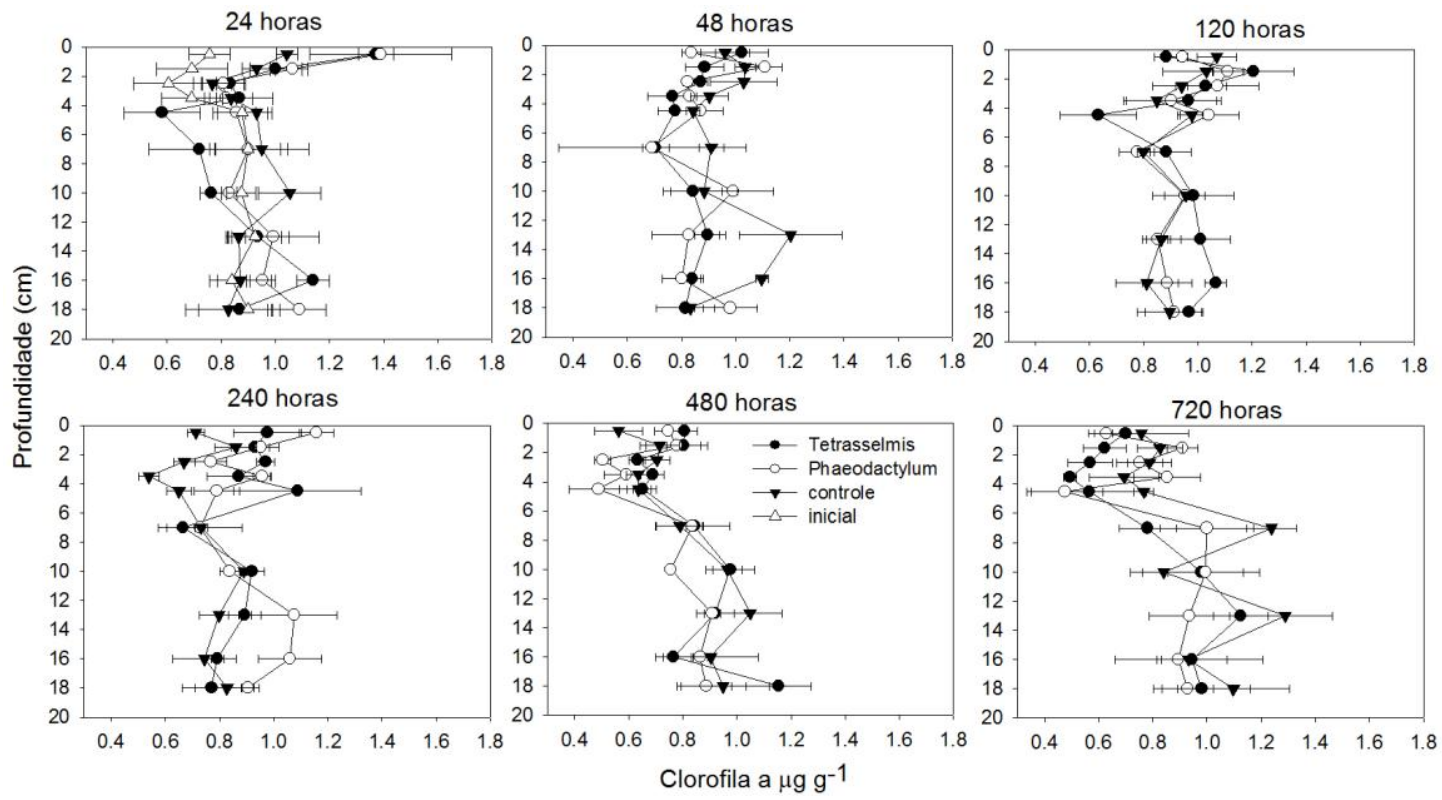

Figura 3.1: Perfis de clorofila-a ( $\mu \mathrm{g} \mathrm{g}^{-1}$ sedimento seco) dos primeiros $20 \mathrm{~cm}$ do sedimento, média \pm erro-padrão, durante os períodos amostrados.
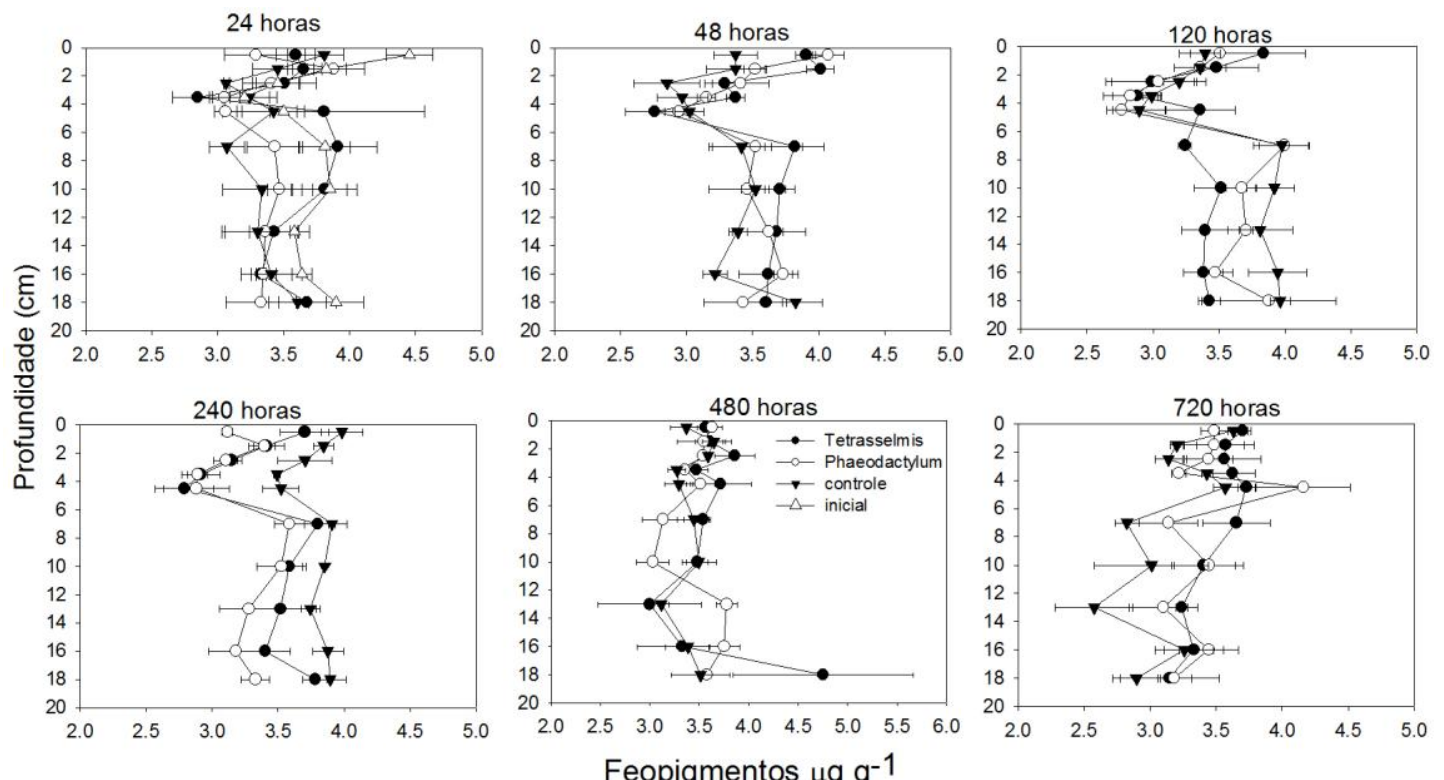

Figura 3.2: Perfis de feopigmentos ( $\mu \mathrm{g} \mathrm{g}^{-1}$ sedimento seco) dos primeiros $20 \mathrm{~cm}$ do sedimento, média \pm erro-padrão, durante os períodos amostrados. 

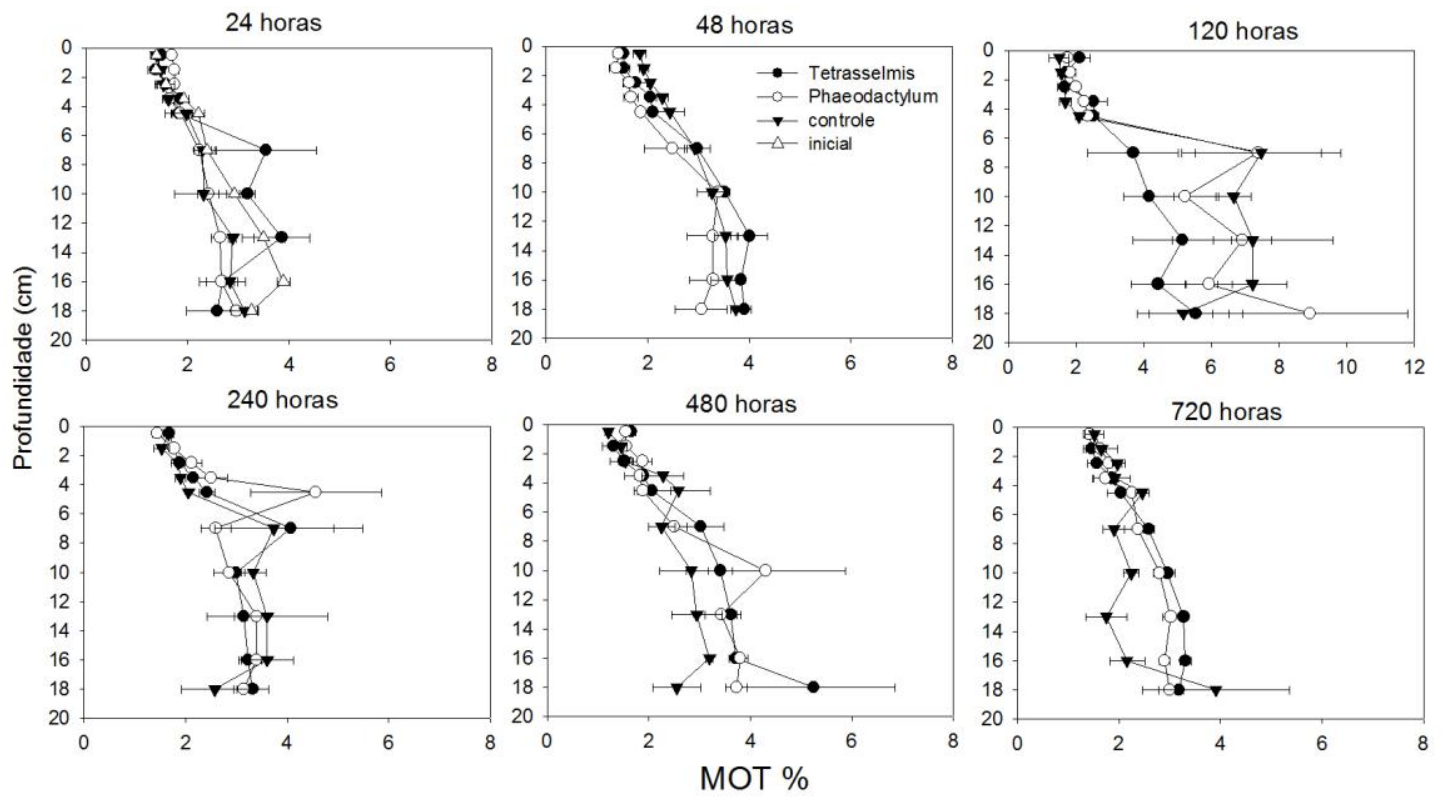

Figura 3.3: Perfis de MOT (\%) dos primeiros $20 \mathrm{~cm}$ do sedimento, média \pm erropadrão, durante os períodos amostrados.

\subsubsection{Densidade de procariotos}

A densidade total de procariotos foi similar entre os tratamentos e controle durante todo o período experimental (Figura 3.4). De um modo geral os valores foram maiores na camada superficial do sedimento, diminuindo na camada subsuperficial e voltando a apresentar altos valores em $5 \mathrm{~cm}$ de profundidade. $\mathrm{O}$ tratamento com diatomácea apresentou picos mais acentuados de densidade em $5 \mathrm{~cm}$ de profundidade nos períodos de $48 \mathrm{~h}$ e 120 h após a adição das algas (Figura 3.4). Após 720 h de experimento, os valores de densidade tornaram-se mais homogêneos na coluna sedimentar, com o tratamento de Tetrasselmis apresentando um pico de densidade em 5 $\mathrm{cm}$ de profundidade (Figura 3.4).

Quando consideramos a densidade apenas de células vivas, o padrão de distribuição vertical apresenta maior variação durante o período de amostragem (Figura 3.5). Após 24 h da adição das algas, o tratamento com Tetrasselmis apresentou maiores densidades na camada superficial e nos $5 \mathrm{~cm}$ de profundidade. Já no tratamento com Phaeodactylum e no controle, os valores aumentaram na camada subsuperficial (1-2 $\mathrm{cm}$ ), mantendo-se constantes com a profundidade (Figura 3.5). Nos tempos de $48 \mathrm{~h}$ e $120 \mathrm{~h} \mathrm{o}$ tratamento com Phaeodactylum mostrou picos acentuados em $5 \mathrm{~cm}$ de profundidade, enquanto o tratamento com Tetrasselmis e o controle apresentaram valores mais homogêneos (Figura 3.5). Nas amostragens feitas após 240 h e 480 h de experimento foram observados maiores valores de densidade na camada superficial e 
em $5 \mathrm{~cm}$ de profundidade em ambos os tratamentos e no controle, e novamente após $720 \mathrm{~h}$ de experimento. No tratamento com Tetrasselmis houve um pico em $5 \mathrm{~cm}$ de profundidade, enquanto em Phaeodactylum e controle os valores foram mais homogêneos na coluna sedimentar (Figura 3.5).

Houve uma correlação positiva entre os valores de densidade total e densidade de vivos $(\mathrm{r}=0.878 ; \mathrm{p}<0.000)$. A densidade de vivos correlacionou-se negativamente com os feopigmentos $(\mathrm{r}=-0.285 ; \mathrm{p}=0.407)$. A PCA realizada mostrou uma explicação de $64,1 \%$ nos dois primeiros eixos, separando as amostras principalmente quanto ao estrato sedimentar (Figura 3.6).
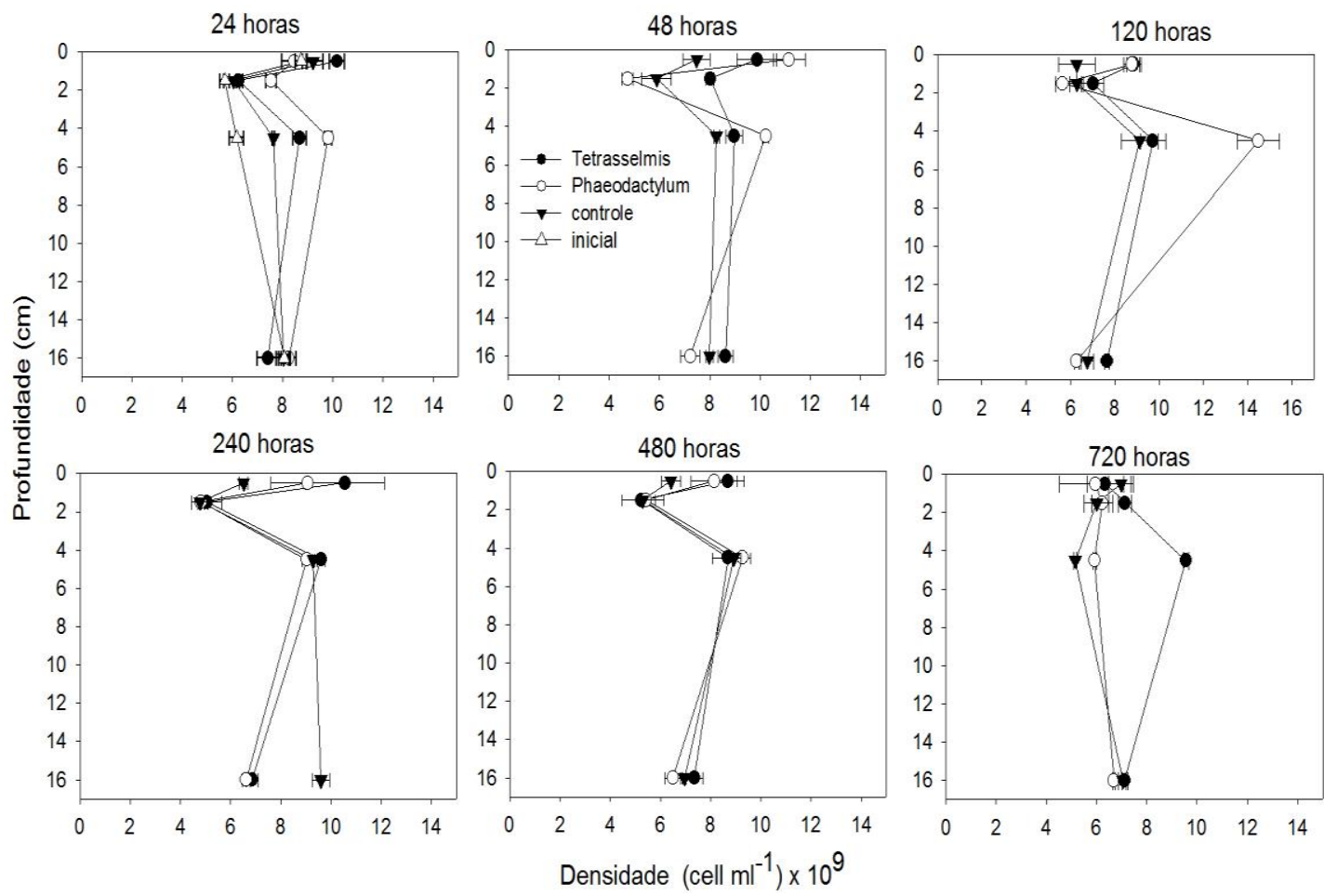

Figura 3.4: Perfis de densidade total de procariotos (células $\mathrm{ml}^{-1}$ ) em quatro camadas da coluna sedimentar $(0-1,1-2,4-5$ e 14-17 cm), média \pm erro padrão, nos tempos amostrados. 

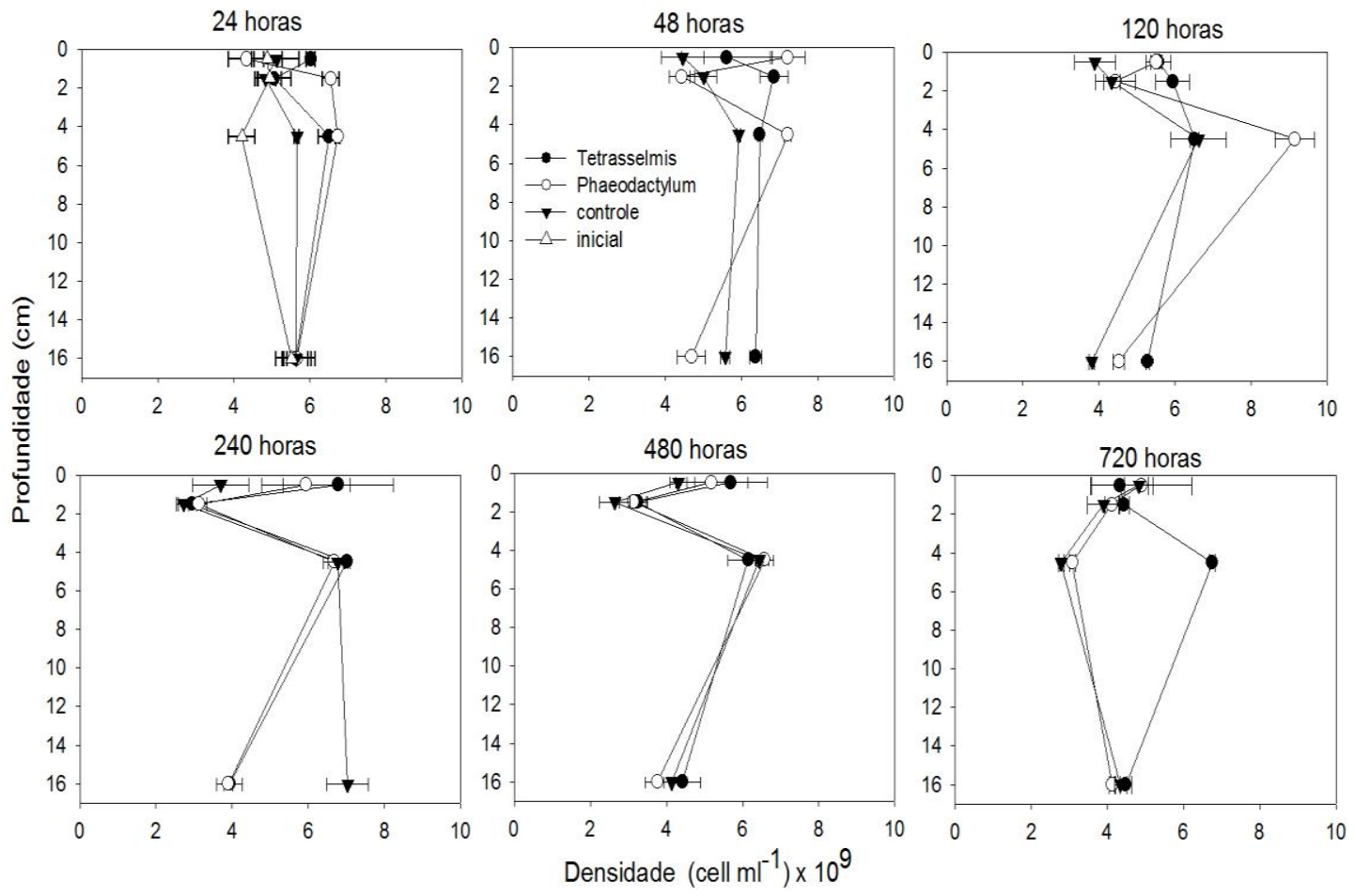

Figura 3.5: Perfis de densidade de procariotos vivos (células $\mathrm{ml}^{-1}$ ) em quatro camadas da coluna sedimentar $(0-1,1-2,4-5$ e 14-17 cm), média \pm erro padrão, nos tempos amostrados.

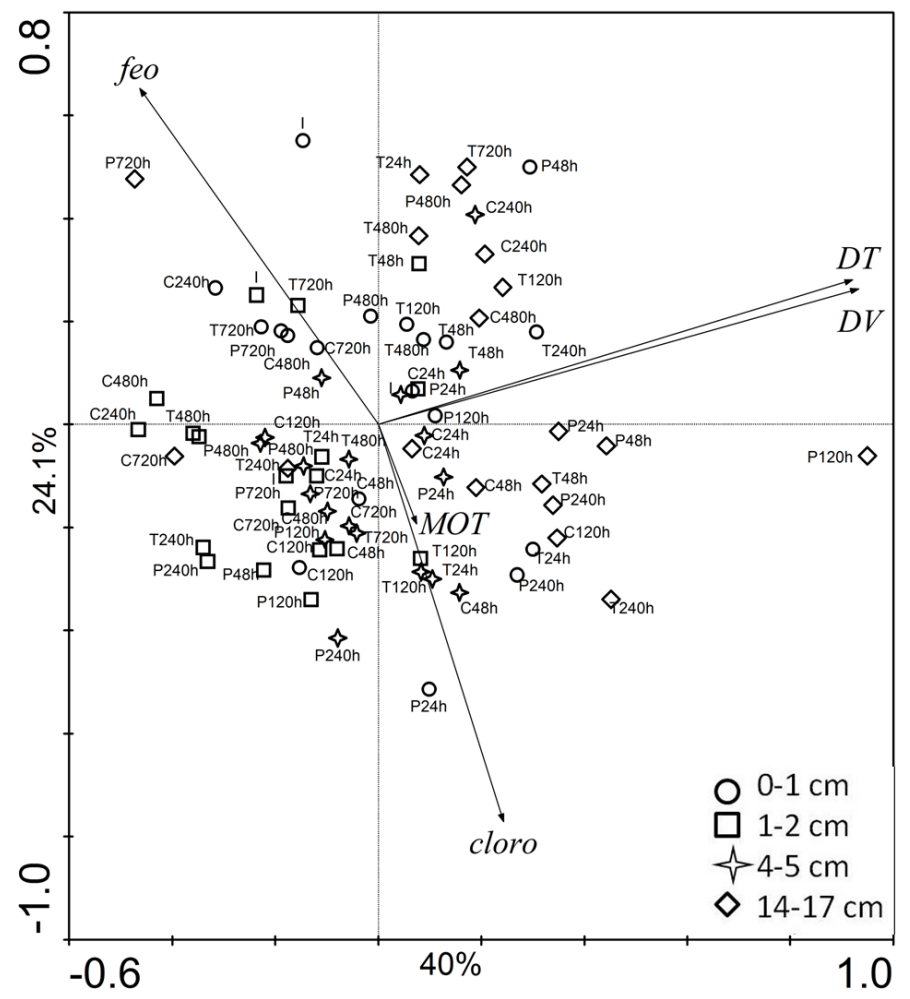

Figura 3.6: Análise de Componentes Principais (PCA) das variáveis encontradas durante o período experimental. $\mathrm{T}=$ tratamento com Tetrasselmis $; \mathrm{P}=$ tratamento com Phaeodactylum; $\mathrm{C}=$ controle $; \mathrm{Chl}=$ clorofila- $\mathrm{a} ; \mathrm{Feo}=$ feopigmentos; $\mathrm{DT}=$ Densidade total de procariotos; $\mathrm{DV}=$ Densidade de procariotos vivos. 


\subsubsection{DGGE e diversidade bacteriana}

A estrutura da comunidade de bactérias do sedimento foi comparada com base na análise de DGGE do gene $16 \mathrm{~S}$ do rRNA. Foram realizados quatro DGGE para observar a influência dos tratamentos nas comunidades de cada camada sedimentar e um último onde algumas amostras foram escolhidas para observar a diferenciação entre as camadas do sedimento. A análise de DGGE mostrou um grande número de bandas, principalmente na camada intermediária do sedimento $(4-5 \mathrm{~cm})$ (Figura 3.7). Na camada subsuperficial (1-2 cm), o número de bandas aumentou com o tempo tanto no controle quanto nos tratamentos. Já na camada intermediária, não houve grandes mudanças no número de bandas relacionadas ao tratamento ou ao tempo de amostragem. Na camada profunda $(14-17 \mathrm{~cm})$, o número de bandas diminuiu com o tempo de amostragem (Figura 3.7). O DGGE referente à distribuição vertical foi semelhante às análises feitas separadamente (Figura 3.7).
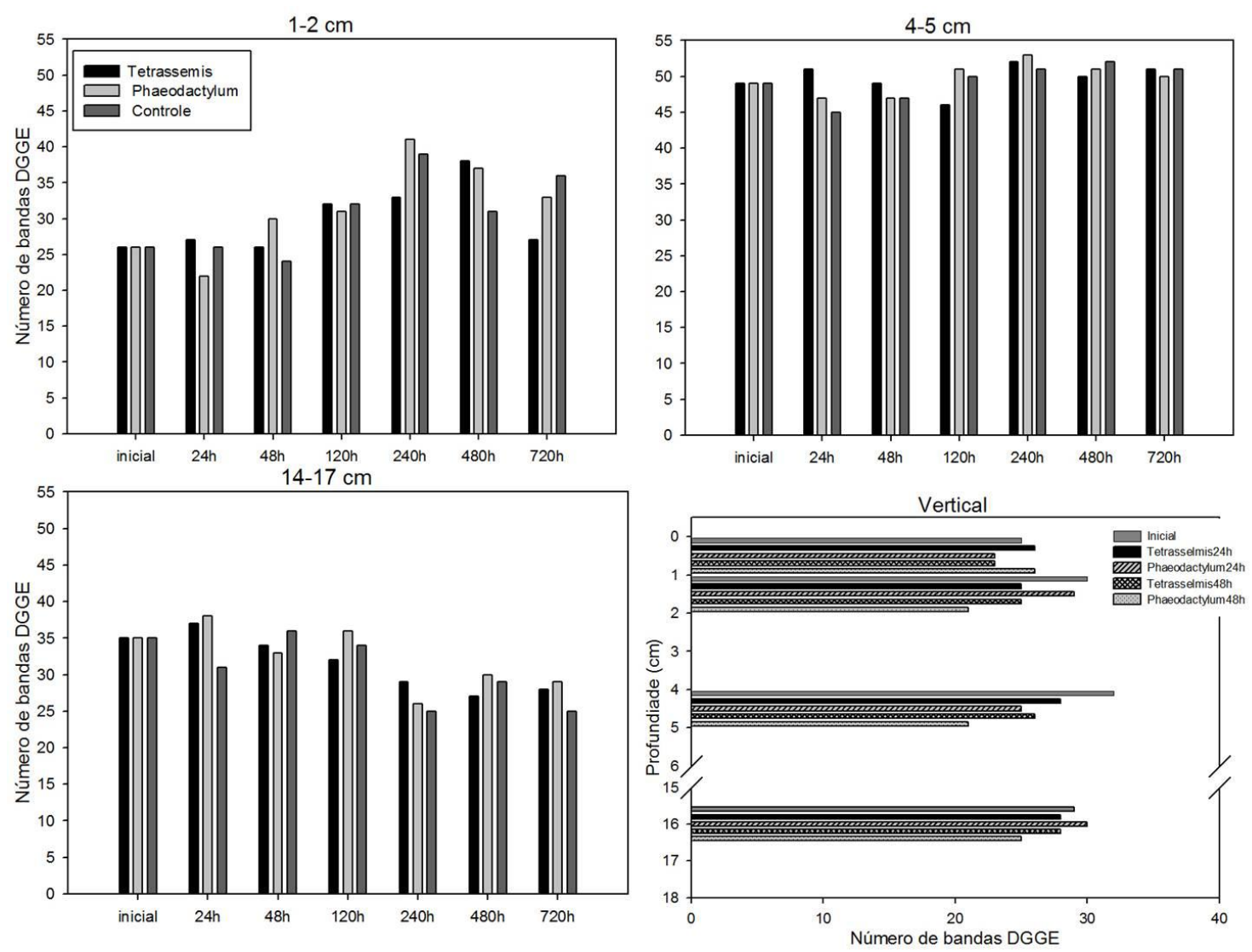

Figura 3.7: Número de bandas identificadas no gel de DGGE da comunidade bacteriana nos estratos do sedimento. 
A comunidade bacteriana do sedimento mostrou um alto grau de similaridade entre as amostras em todas as camadas estudadas. O cluster realizado a partir do padrão de bandas encontradas nas análises de DGGE mostrou mais de $78 \%$ de similaridade entre as amostras na camada subsuperficial (1-2 cm; Figura 3.8), mais de $84 \%$ de similaridade na camada intermediária (4-5 cm; Figura 3.9) e mais de $73 \%$ na camada profunda do sedimento (14-17 cm; Figura 3.10). Tanto na camada subsuperficial quanto na intermediária as amostras foram separadas em dois grandes grupos com mais de $83 \%$ e $88 \%$ de similaridade, respectivamente. Os grupos foram formados principalmente quanto ao período de amostragem, mostrando que o tempo de experimento parece ser mais importante que os tratamentos. Porém, dentro dos grupos observamos que as amostras onde as algas foram adicionadas apresentaram maiores semelhanças entre as comunidades bacterianas com relação ao controle (Figura 3.8 e 3.9). Já as amostras relativas à camada profunda do sedimento foram separadas em quatro grupos com mais de $80 \%$ de similaridade (Figura 3.10). O primeiro grupo foi formado por amostras até $120 \mathrm{~h}$ de experimento, o segundo por amostras dos tratamentos $240 \mathrm{~h}$, o terceiro grupo compreendeu amostras após 480 h de experimento, controle 240 h e Tetrasselmis 720 h. O quarto grupo foi formado pelas amostras do controle e Phaeodactylum 720 h (Figura 3.10).

Para observar mudanças na distribuição vertical das bactérias, um DGGE foi feito com a amostra inicial e tratamentos $24 \mathrm{~h}$ e $48 \mathrm{~h}$ nos estratos estudados (Figura 3.11). O cluster realizado com o padrão de bandas encontrado mostrou uma similaridade de mais de $68 \%$ entre as amostras, formando três grandes grupos. O primeiro grupo foi formado pelas amostras inicial 0-1, 1-2 e 4-5 cm e Phaeodactylum 48 h 4-5 e 14-17 cm. O segundo agrupou as amostras restantes referentes à camada 14-17 cm e as amostras de Phaeodactylum 24 h 0-1 e 1-2 cm. O restante das amostras foi agrupado no terceiro grupo, com exceção da amostra Phaedactylum 48 h 0-1 cm, que apresentou as maiores diferenças não estando em nenhum grupo formado (Figura 3.11).

Análises de CCA foram realizadas com o padrão de bandas encontrada para cada DGGE e com as variáveis sedimentares medidas (Figura 3.12). Na camada subsuperficial, a CCA explicou apenas $22,6 \%$ da variação dos dados. Apenas a densidade de procariotos vivos apresentou influência significativa na variação da comunidade nas amostras, explicando $8 \%$ da variação das bandas encontradas (Figura 3.12a). Na camada intermediária, apenas a clorofila-a apresentou influência significativa na variação da comunidade e explicou apenas $7 \%$ do padrão de bandas encontrado. A 
CCA explicou $20 \%$ nos dois primeiros eixos e separou as amostras principalmente quanto ao tempo de amostragem (Figura 3.12b). Na camada profunda não foi encontrada variável que explicasse significativamente a distribuição das bactérias e a CCA explicou 30,7\% da variação dos dados nos dois primeiros eixos, separando principalmente as amostras dos tempos $480 \mathrm{~h}$ e $720 \mathrm{~h}$ do restante (Figura 3.12c). Já na análise referente à distribuição vertical, a CCA explicou 37,6\% da variação dos dados nos dois primeiros eixos e separou as amostras mais em relação ao extrato. Apenas a MOT apresentou influência significativa no padrão de variação encontrado (Figura $3.12 d)$.

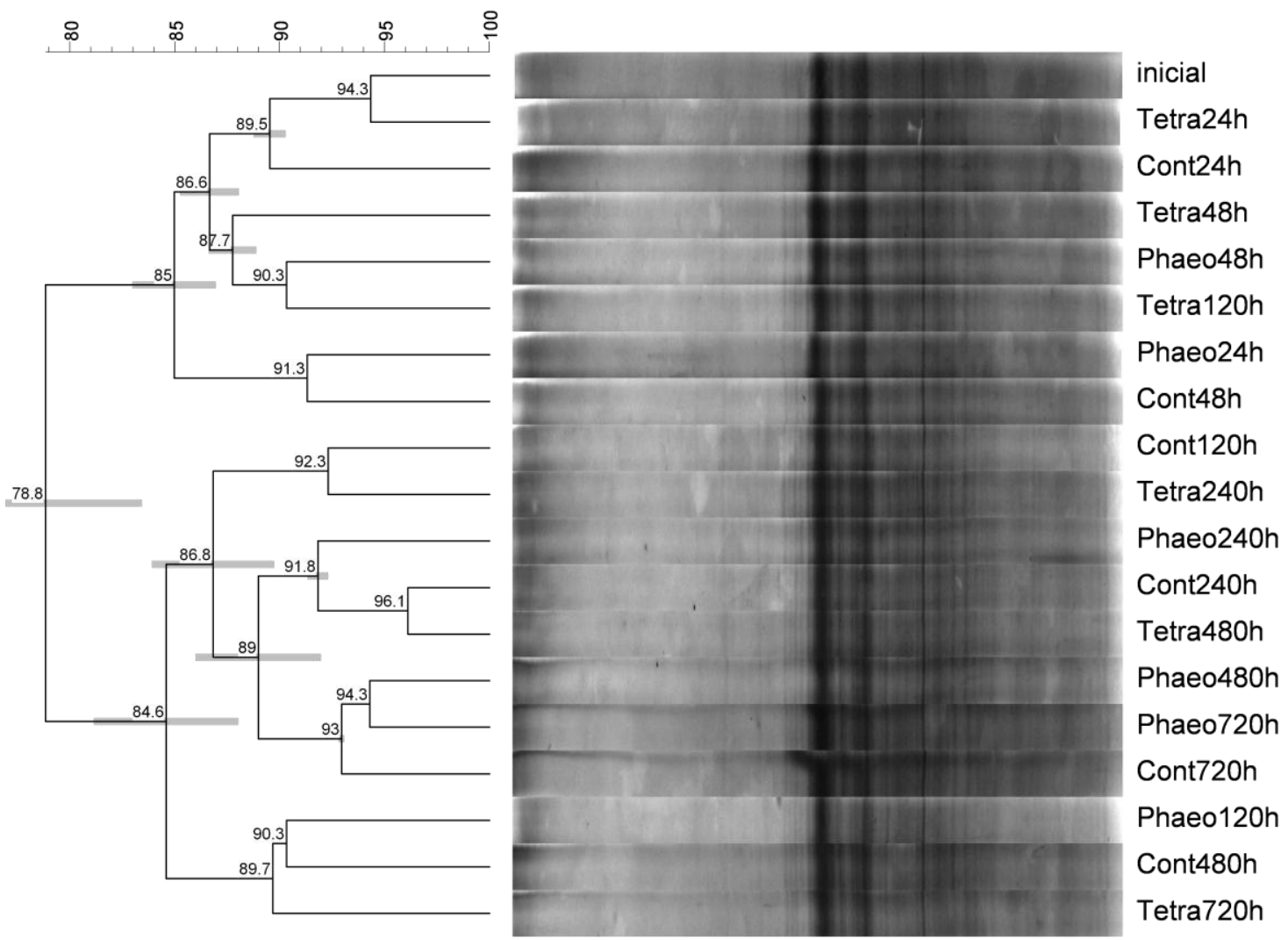

Figura 3.8: Análise de agrupamento do padrão de bandas de DGGE das bactérias sedimentares da camada 1-2 cm usando a análise UPGMA. Matriz de similaridade calculada usando DICE. 

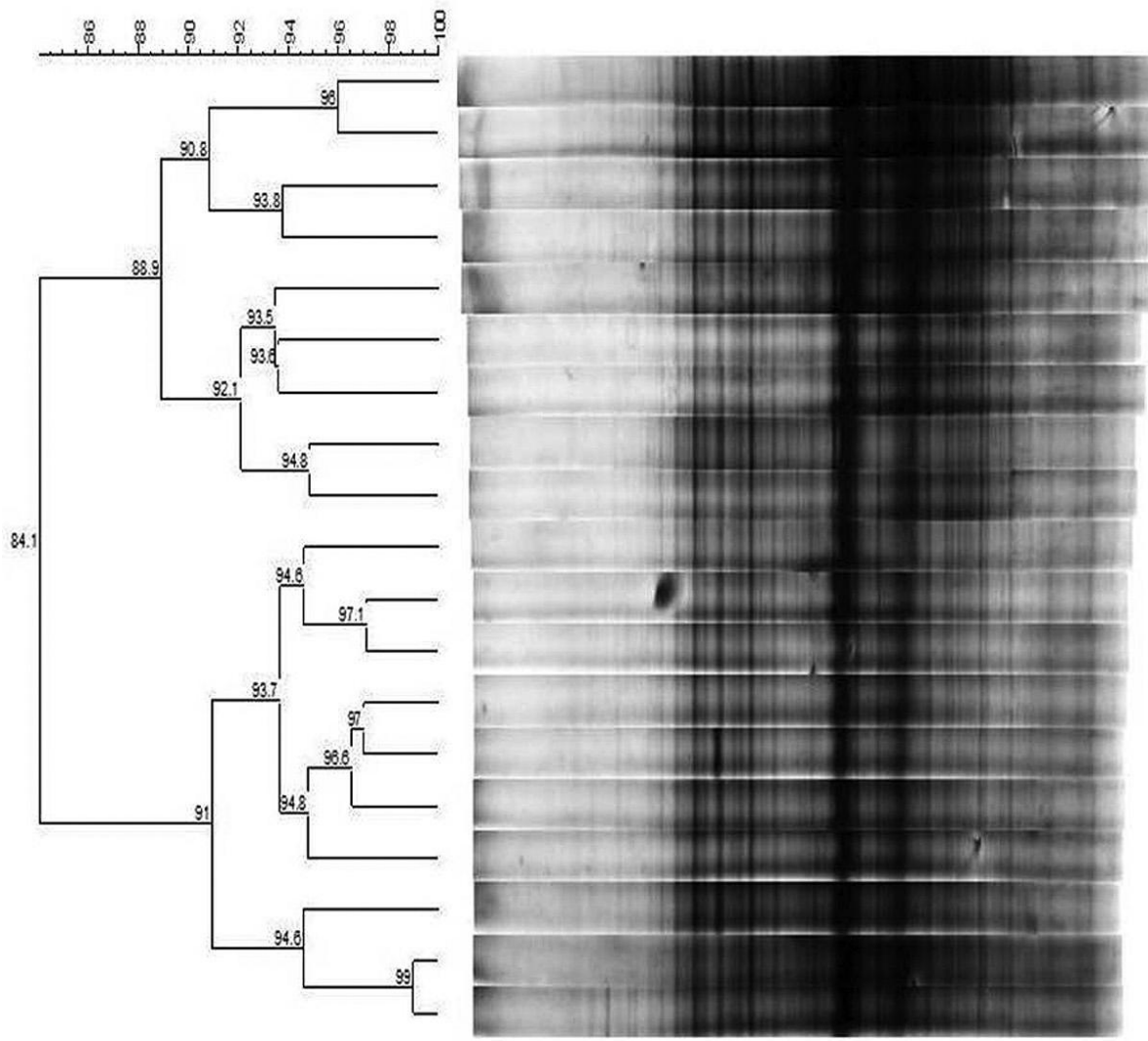

Inicial

Tetra24h

Phaeo24h

Tetra48h

Cont24h

Cont48h

Phaeo48h

Phaeo120h

Tetra120h

Cont120h

Tetra240h

Phaeo240h

Cont240h

Tetra480h

Phaeo480h

Cont480h

Tetra720h

Cont720h

Phaeo720h

Figura 3.9: Análise de agrupamento do padrão de bandas de DGGE das bactérias sedimentares da camada 4-5 $\mathrm{cm}$ usando a análise UPGMA. Matriz de similaridade calculada usando DICE.

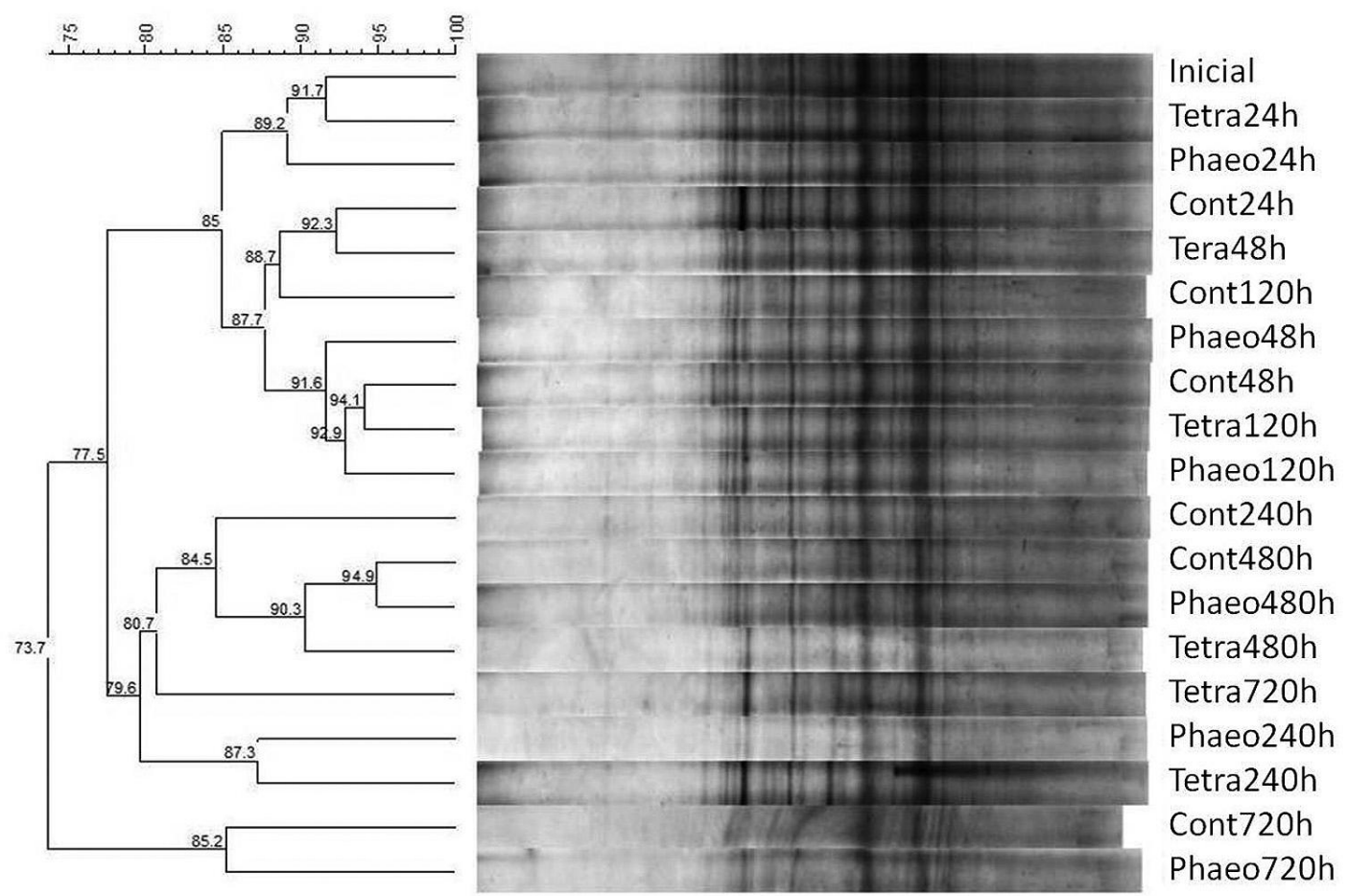

Figura 3.10: Análise de agrupamento do padrão de bandas de DGGE das bactérias sedimentares da camada 14-17 cm usando a análise UPGMA. Matriz de similaridade calculada usando DICE. 

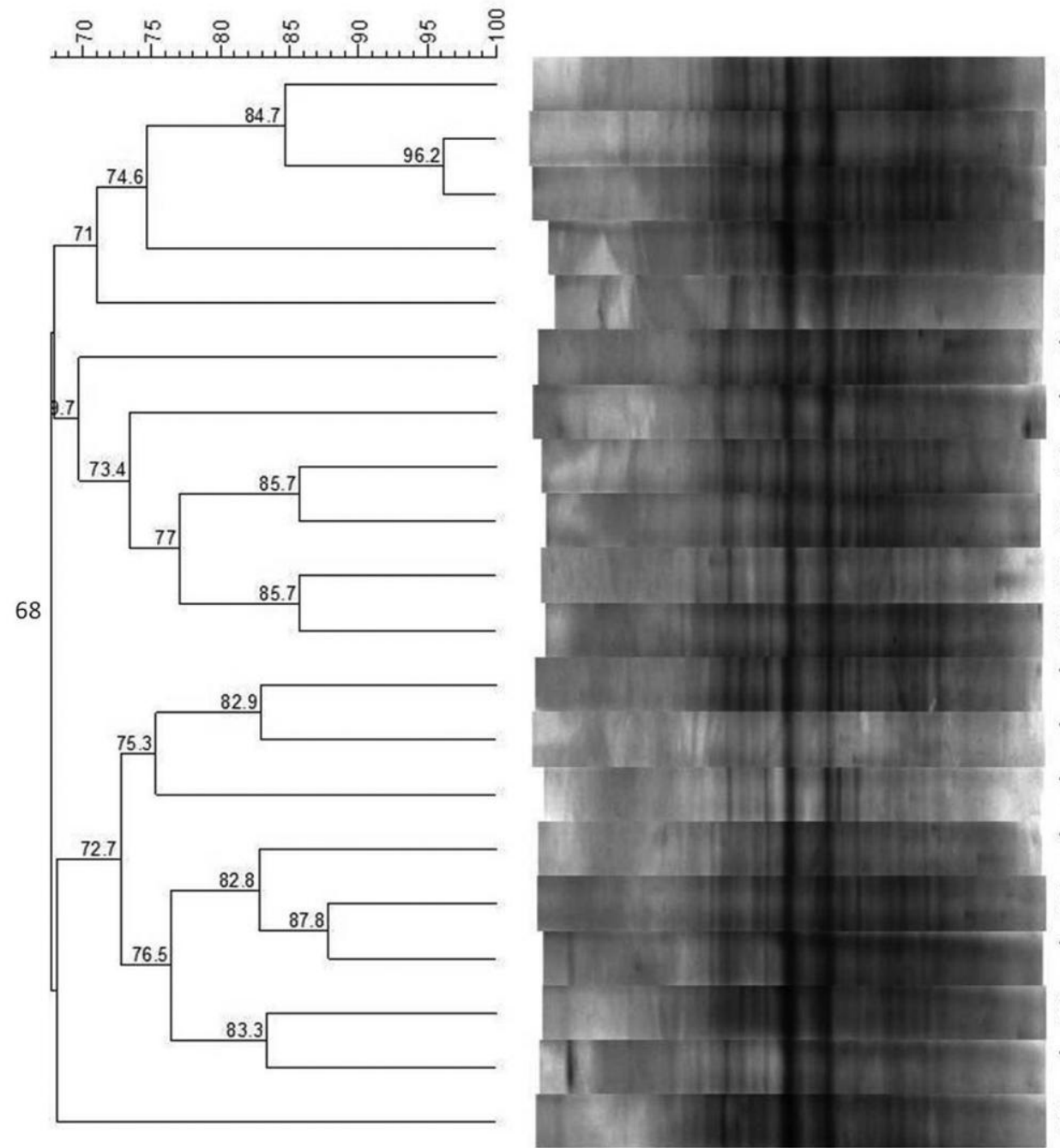

Inicial 1

Inicial2

Inicial5

Phaeo48h5

Phaeo48h9

Tetra24h9

Tetra48h9

Inicial9

Phaeo24h9

Phaeo24h1

Phaeo24h2

Tetra24h1

Tetra24h2

Tetra48h1

Tetra24h5

Phaeo24h5

Tetra48h5

Phaeo48h2

Tetra48h2

Phaeo48h1

Figura 3.11: Análise de agrupamento da estrutura vertical do padrão de bandas de DGGE das bactérias sedimentares usando a análise UPGMA. Matriz de similaridade calculada usando DICE. 

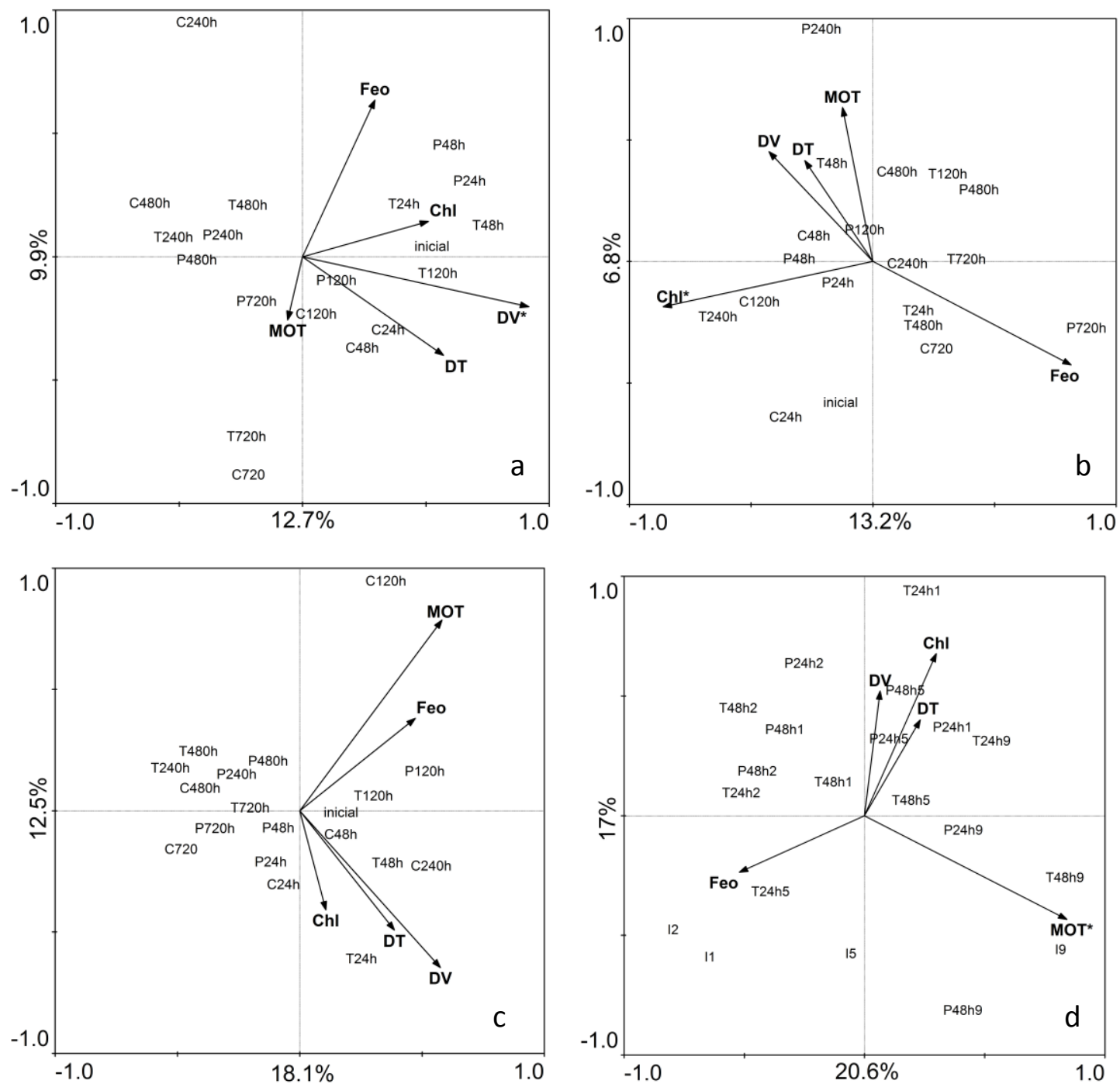

Figura 3.12: Análise de correspondência canônica (CCA) usando os perfis de PCR-DGGE das amostras do sedimento e as variáveis sedimentares medidas. a. 1-2 cm; b. 4-5 cm; c. 14-17 cm; d. distribuição verical. * variável com influência significativa na variação das bandas de DGGE, segundo teste de Monte Carlo (9999 permutações).

\subsection{Discussão}

\subsubsection{Variáveis abióticas}

A quantidade e qualidade da matéria orgânica estão entre os principais fatores que influenciam na distribuição das comunidades no ambiente bêntico. Dessa forma, o conhecimento da distribuição da matéria orgânica na coluna sedimentar é de fundamental importância para o entendimento da distribuição dos organismos.

O enterramento da matéria orgânica em sedimentos marinhos representa o dissipador em longo prazo predominante na biogeoquímica global do ciclo do carbono reduzido. Sedimentos costeiros e de plataforma, que recebem grandes quantidades de 
materiais alóctones e autóctones são responsáveis por $90 \%$ do enterramento do carbono orgânico no oceano (Hedges \& Keil, 1995). Vários fatores são conhecidos por influenciar a preservação da matéria orgânica em sedimentos marinhos, tais como taxas de sedimentação, produtividade primária, profundidade da coluna d'água, tempo de exposição ao oxigênio e origem da matéria orgânica (Henrichs, 1992; Aller, 1994; Canfield, 1994; Mayer, 1994; Hedges \& Keil, 1995; Hartnett et al., 1998; Hedges et al., 1999).

Nas primeiras camadas do sedimento a matéria orgânica é decomposta rapidamente, e a distribuição vertical da matéria orgânica é controlada principalmente por processos de degradação e mistura física das partículas sedimentares (Sun et al., 1994; Kristensen et al., 1995; Stoeck \& Kröncke, 2001). Geralmente, nestas camadas, a labilidade da matéria orgânica diminui com a profundidade do sedimento, mesmo em sedimentos costeiros com bioturbação moderada (Kristensen, 1993). Isso ocorre principalmente devido ao constante input de material fresco produzido na camada de água sobrejacente que alcança a superfície do sedimento e é rapidamente consumido pelos orgânicos bênticos (Canuel \& Martens, 1996; Kristensen \& Holmer, 2001). Porém, a quantidade de matéria orgânica parece aumentar com a profundidade do sedimento devido principalmente ao transporte pela própria fauna (i.e. bioturbação), mantendo a matéria orgânica preservada nas camadas mais profundas do sedimento devido a baixas taxas de decomposição (Mather \& Parkes, 2000; Pfannkuche et al., 2000; Stoeck \& Kröncke, 2001).

No presente estudo os valores de feopigmentos e MOT foram quase sempre maiores nas camadas mais profundas do sedimento. O que confirma o já explicado acúmulo de material orgânico mais refratário nas camadas mais profundas da coluna sedimentar. Já os valores de clorofila-a foram maiores nas camadas superficiais do sedimento apenas nos primeiros dias de experimento. A partir de 10 dias de experimento a clorofila-a foi encontrado em maiores concentrações nas camadas mais profundas da coluna sedimentar. O acúmulo de material orgânico lábil observado nas camadas profundas do sedimento deve estar relacionado com a ausência de fauna e distúrbios físicos no sedimento, o que faz com que o oxigênio penetre apenas alguns milímetros na coluna sedimentar e mantenha a maior parte do sedimento anóxico. É bom lembrar também que o experimento contou com apenas uma adição de material algal no início e foi mantido no escuro durante o restante do período, não havendo então adição de matéria orgânica ao sedimento pela produção primária. Desta forma, o 
material fresco encontrado na superfície do sedimento pôde ser rapidamente metabolizado, já que a maior parte dos micro-organismos aeróbicos é capaz de mineralizar rapidamente a maioria dos materiais orgânicos complexos (Sun et al., 1993; Kristensen \& Holmer, 2001). Já na zona anóxica, a degradação da matéria orgânica ocorre em taxas mais lentas, já que apenas um único tipo de micro-organismo não é capaz de completar a mineralização da matéria orgânica sozinho, sendo necessário o estabelecimento de consórcios formados por dois ou mais tipos de micro-organismos (Fenchel et al., 1998). Desta forma, a diminuição da qualidade da matéria orgânica (labilidade e degradabilidade) e as mudanças metabólicas com a profundidade fazem com que haja uma diminuição nas taxas de degradação com o aumento da profundidade de sedimentos marinhos (Canfield, 1994; Kristensen, 2000; Kristensen \& Holmer, 2001).

\subsubsection{Comunidade microbiana}

Geralmente a distribuição da densidade de micro-organismos está altamente relacionada com a quantidade e qualidade da matéria orgânica em sedimentos marinhos. Isso leva a uma diminuição da densidade microbiana com o aumento da profundidade do sedimento, acompanhando tendências nos valores de clorofila-a (Parkes, et al., 2000; Eardly et al., 2001; Köster \& Meyer-Reil, 2001; Smith et al., 2002; Polymenakou et al., 2007). No presente estudo, a densidade não apresentou correlação com a clorofila-a, mas sim com feopigmentos. Desta forma, a alta densidade encontrada nas camadas intermediárias do sedimento deveu-se aos altos valores de MOT e feopigmentos nestas camadas. A falta de predadores nas camadas mais profundas do sedimento também pode explicar os valores elevados de micro-organismos. A ausência de macrofauna e distúrbios físicos no sedimento fazem com que o oxigênio penetre apenas alguns milímetros na coluna sedimentar e mantenha a maior parte do sedimento anóxico, com a maior parte dos protozoários e da meiofauna presente nestas camadas. Alguns estudos vêm demonstrando que tais organismos são os principais predadores de procariotos no sedimento marinho (Dietrich \& Arndt, 2000; Garstecki \& Wickham, 2001).

A densidade total de procariotos não mostrou grandes diferenças em sua distribuição vertical devido ao tratamento, porém as células vivas mostraram respostas diferentes de acordo com a alga adicionada nos primeiros dias de experimento. Como discutido no Capítulo 2, a resposta microbiana à adição de Tetrasselmis foi mais rápida 
do que à de Phaeodactylum. Isso se refletiu também na distribuição vertical dos procariotos na coluna sedimentar. Após $24 \mathrm{~h}$ da adição das algas, altos valores de densidade foram encontrados na camada superficial do sedimento no tratamento com Tetrasselmis, mas não no com Phaeodactylum, onde os maiores valores ocorreram subsuperficialmente. Já em 48 h após a adição o padrão se inverteu, com maiores valores na superfície no tratamento com diatomácea e na camada subsuperficial no tratamento com flagelado. Experimentos vêm demonstrando que, na presença de material fresco, as bactérias ativas podem se mover rapidamente no sedimento em direção às camadas com maior quantidade de matéria orgânica lábil (Parkes et al., 2000).

Acompanhando a maior densidade encontrada na camada intermediária do sedimento, a análise de DGGE mostrou um maior número de bandas na mesma camada. Em geral, é assumido que a energia disponível, variação de nichos e a quantidade de recursos alimentares são maiores na superfície do sedimento do que nas camadas mais profundas. Dessa forma, poderíamos esperar que um maior número de bandas na camada superficial. No presente estudo, entretanto, maiores números foram encontradas nas camadas mais profundas do sedimento. A alta disponibilidade de nutrientes tem sido descrita como um potencial causador de diminuição da diversidade bacteriana (Hewson et al., 2003; Böer et al., 2009), presumidamente devido a um aumento na exclusão competitiva (Abrans, 1995). A alta disponibilidade de nutrientes inorgânicos e matéria orgânica lábil nas camadas superficiais do sedimento pode ter favorecido um rápido crescimento de generalistas tolerantes a oxigênio, enquanto as camadas profundas podem ter suportado uma comunidade microbiana mais heterogênea de táxons anaeróbicos de crescimento lento e com capacidades metabólicas mais variáveis.

As análises mostraram um alto grau de similaridade entre as comunidades de cada camada sedimentar e maiores mudanças em função do tempo do que do tratamento. Esses resultados confirmam estudos anteriores de que as comunidades bacterianas são similares a uma dada profundidade do sedimento, mostrando uma distribuição vertical relativamente homogênea quando os parâmetros ambientais são também relativamente constantes (Braker et al., 2001; Edlund et al., 2006; 2008). Maiores mudanças na comunidade entre os tratamentos e o controle foram observados logo após a adição das algas, sugerindo que a chegada de material lábil a superfície do sedimento pode também influenciar as comunidades bacterianas nas camadas mais profundas do sedimento. A chegada de alimento fresco na superfície do sedimento leva 
a um aumento na atividade microbiana, o que resulta em modificações na distribuição do oxigênio e do potencial redox na coluna sedimentar, levando a alterações na distribuição de bactérias com a profundidade (Sheppard \& Lloyd, 2002).

As CCAs mostraram que as variáveis ambientais medidas explicaram apenas parte da diversidade bacteriana encontrada. Dentre essas, a quantidade de matéria orgânica foi a mais importante. Vários estudos têm evidenciado que as comunidades microbianas apresentam padrões temporais e espaciais que não podem ser explicados por variações nos parâmetros ambientais contemporâneos. Isso pode ser feito apenas analisando todo o histórico da comunidade (Martiny et al., 2006; Ramette \& Tiedje, 2007). Apesar disso, muitos fatores que são importantes para explicar a variação vertical da comunidade bacteriana não foram medidos no presente estudo, tais como o conteúdo de carbono orgânico, nutrientes da água intersticial, $\mathrm{pH}$ e potencial redox. Estudos têm demonstrado que variações na distribuição vertical da comunidade microbiana do sedimento são principalmente relacionadas a mudanças no potencial redox do sedimento e concentração de carbono orgânico (Urakawa et al., 2000; Braker et al., 2001; Edlund et al., 2008; Böer et al., 2009).

Concluindo, nossos dados mostraram que a comunidade microbiana parece não apresentar grandes variações em densidade e diversidade quando os parâmetros ambientais são relativamente constantes. Dessa forma, a adição de algas na superfície do sedimento afeta muito mais a camada superficial do sedimento não tendo muita influência nas camadas mais profundas. A ausência de macrofauna e de distúrbios físicos levou a uma estabilidade nos parâmetros ambientais das camadas mais profundas, levando a maiores densidades e diversidade da comunidade microbiana nas profundidades intermediárias do sedimento. 


\section{Capítulo 4: Resposta da comunidade microbiana do sedimento a eventos de ressuspensão em sedimentos marinhos costeiros}

\subsection{Introdução}

A ressuspensão é um processo físico que ocorre em todo o ambiente marinho, tanto em áreas rasas costeiras quanto em ambiente profundo (Vangriesheim \& Khripounoff, 1990; Thomsen et al., 1994). Em bacias rasas e regiões costeiras, onde a coluna d'água e o ambiente bêntico são altamente acoplados, a ressuspensão é um importante fator no controle da degradação e redistribuição da matéria orgânica (Jönsson et al., 2005). Nesses locais ventos e tempestades, marés, ondas e interações entre ondas e correntes resultam na resuspensão de sedimento e aumentam a turbidez da água (Poter et al. 2010). A ressuspensão também altera a estrutura das camadas sedimentares, promovendo a redistribuição de sedimentos e enriquecendo a coluna de água com nutrientes particulados e dissolvidos (Wainright, 1990; Tengberg et al., 2003).

Estudos relevantes têm sido feitos sobre o efeito da ressuspensão na comunidade microbiana na coluna d' água (Wainright, 1990; Arin et al., 2002; Garstecki et al., 2002). Estudos em campo e laboratoriais têm demonstrado que a ressuspensão pode aumentar a abundância e biomassa do bacterioplâncton (Wainright, 1987; Ritzrau \& Graf, 1992), bem como as taxas de decomposição da matéria orgânica e aumento da quantidade de carbono orgânico e particulado na coluna d'água (Hopkinson, 1985; Arfi \& Bouvy, 1995; Cotner et al., 2000; Tengberg et al., 2003).

Vários estudos em campo e experimentais têm demonstrado mudanças significativas na cadeia trófica microbiana do sedimento em resposta a eventos de ressuspensão (Fiordelmondo \& Pusceddu, 2004; Fiordelmondo et al., 2003; Pusceddu et al., 2005; Polymenakou et al., 2005b). Esses estudos sugerem que eventos de ressuspensão severos causados por dragagens e arrastos de fundo podem ter grandes implicações na biogeoquímica dos mares costeiros, com mudanças profundas na atividade bacteriana bêntica e nas taxas de mineralização do carbono orgânico. Enquanto a maioria dos estudos observa uma diminuição inicial da abundância e biomassa bacteriana, a atividade e taxas de mineralização do carbono parecem ser estimuladas pela ressuspensão do sedimento, aumentando a disponibilidade de 
nutrientes e tendo importantes consequências para a cadeia trófica de regiões marinhas costeiras (Garstecki \& Wickham, 2001; Watling et al., 2001; Fiordelmondo \& Pusceddu, 2004; Fiordelmondo et al., 2003; Psceddu et al., 2005; Polymenakou et al., 2005b). Além disso, Ståhlberg et al., 2006 observou que mesmo eventos curtos de ressuspensão causados por ondas e ventos podem aumentar significativamente as taxas de mineralização do carbono orgânico no sedimento. Apesar disso, a resposta microbiana do sedimento a eventos de ressuspensão é ainda controverso e pouco estudado (Almroth et al., 2009), principalmente quanto à resposta nas mudanças específicas da comunidade.

A região costeira de Ubatuba, no litoral norte do Estado de São Paulo, é caracterizada por apresentar intensa incidência de frentes frias entre os meses de março e novembro (Mahiques et al., 1998). Estes eventos promovem a ressuspensão dos sedimentos, disponibilizando materiais orgânicos e nutrientes para a coluna de água (Gaeta et al., 1999). O objetivo do presente estudo foi observar a resposta da comunidade microbiana do sedimento a eventos de ressuspensão ocorrendo naturalmente no ambiente marinho na região costeira do litoral norte de São Paulo, sudeste do Brasil. Para tanto foi simulado em laboratório um evento de ressuspensão do sedimento, onde foi monitorada a comunidade bacteriana após o evento, bem como características sedimentares e taxas de fluxo de oxigênio.

\subsection{Material e Métodos}

\subsection{1. Área de estudo}

Na região sul e sudeste do Brasil a passagem de frentes frias é um evento comum que ocorre durante o ano todo. Porém, durante os meses de outono e inverno essas frentes frias aumentam em intensidade e frequência (Centro de Previsão do Tempo e Estudos Climáticos-CPTEC e Instituto Nacional de Pesquisas Espaciais-INPE). O ponto escolhido localiza-se na Plataforma Continental Sudeste Brasileira - PCSE, na costa de Ubatuba, litoral norte do Estado de São Paulo, com profundidade em torno de $35 \mathrm{~m}$, onde foi previamente obsevado um alto grau de ressuspensão sedimentar após passagens de frentes frias na região. A área possui um regime oceanográfico de transição entre águas costeiras e de plataforma continental e apresenta uma dinâmica temporal dependente principalmente do vento (direção, intensidade e tempo de atuação), das correntes e do relevo submarino. No outono-inverno, os ventos de quadrante sul 
(atribuídos às frentes frias) levam ao esfriamento das águas superficiais e a intensificação de misturas devido aos ventos fortes, o que torna as águas próximas à costa quase homogêneas (Castro-Filho et al., 1987). O aumento de frentes frias e homogeneidade da coluna de água durante esta época do ano tornam a ressuspensão e regeneração de nutrientes os principais fatores dirigindo a produtividade primária na região (Sassi \& Kutner, 1982).

\subsubsection{Amostragem e montagem experimental}

As amostras foram coletadas na região de Ubatuba, costa norte do estado de São Paulo, na plataforma sudeste brasileira, em uma área de transição entre águas costeiras e de plataforma $\left(23^{\circ} 34,480^{\prime} \mathrm{S}-45^{\circ} 00,271^{\prime} \mathrm{W}\right.$ e $35 \mathrm{~m}$ de profundidade). Os testemunhos foram coletados com um mini-multicorer e fatiado a bordo em quatro profundidades ( 0 2, 2-5, 5-10, 10-20 cm), homogeneizados e peneirados em peneira de $1 \mathrm{~mm}$. Um total de 39 testemunhos (10 cm de diâmetro) foi preenchido com o sedimento peneirado, até $20 \mathrm{~cm}$ de coluna sedimentar, respeitando-se as profundidades. Os testemunhos foram mantidos em sistemas separados (um tratamento e um controle) sem luz, com oxigenação e circulação em uma sala com temperatura controlada $\left(19^{\circ} \mathrm{C}\right)$.

Após cinco dias de aclimatação, três testemunhos foram tomados para as análises iniciais $(\mathrm{t}=0)$. A ressuspensão foi simulada em 18 testemunhos através de bombas submersas $(280 \mathrm{~L} / \mathrm{h})$ colocadas a uma distância aproximada de $15 \mathrm{~cm}$ acima da coluna sedimentar por $12 \mathrm{~h}$ ininterruptas. Amostragens foram realizadas seis vezes no período total de 30 dias após o período de ressuspensão (t= 24 h, 48 h, 120 h, 240 h, 480 h, 720 h após a adição). Primeiramente, os testemunhos foram incubados para análises de fluxo de oxigênio e, posteriormente, fatiados e a camada superficial $(0-1 \mathrm{~cm})$ foi amostrada para as análises sedimentares (fitopigmentos, MOT, COT e análises microbianas).

\subsubsection{Fluxo de oxigênio}

Três testemunhos do tratamento e controle foram amostrados em cada período para a determinação do oxigênio dissolvido e cálculo de fluxos sedimento-água. Os testemunhos foram selados durante a incubação e um agitador magnético dirigido por um sistema externo de ímãs manteve a circulação interna constante. A incubação foi feita no escuro por 3-3,5h e amostras para análise de oxigênio foram feitas antes e após 
a incubação. O método de Winckler foi usado para as análises de oxigênio (Strickland \& Parsons, 1972). Com os dados foram calculados os fluxos de oxigênio (liberação ou consumo) por $\mathrm{m}^{2}$ da superfície do sedimento por dia $\left(\mathrm{mmol} \mathrm{d}^{-1}\right)$.

\subsubsection{Características sedimentares}

A matéria orgânica total (MOT) foi obtida através do método de calcinação em forno mufla $\left(550^{\circ} \mathrm{C}\right)$ por 2,5-3h (Byers et al., 1978). Fitopigmentos foram extraídos com acetona $100 \%$ por $24 \mathrm{~h} \mathrm{a}-10^{\circ} \mathrm{C}$ e a absorbância foi medida (665 e 750nm) antes e após acidificação com 0,1 N HCl através de um espectrofotômetro (Plante-Cuny, 1978). As concentrações de clorofila-a e feopigmentos foram calculadas aplicando-se a fórmula sugerida por Lorenzen (1967). O carbono orgânico total (COT) foi estimado pelo método de titulação de Walkley-Black modificado para sedimento (Gaudette et al., 1974).

\subsubsection{Densidade de procariotos}

De cada réplica de sedimento amostrada, $1 \mathrm{ml}$ de sedimento foi retirado com seringa estéril e alocado em potes de plástico com $9 \mathrm{ml}$ de formol salino $2 \%$ pré-filtrado em filtro $0,2 \mu \mathrm{m}$. A densidade de procariotos foi determinada através de método de contagem direta em microscópio de epifluorescência, usando um kit de viabilidade Live/Dead (L/D) BacLight (L-7012, Molecular Probes, Eugene, OR; Quéric et al., 2004). A técnica L/D utiliza um kit que contém uma mistura de SYTO 9 como marcador de viabilidade e iodeto propídico como marcador de células com danos de membrana, consideradas como células inviáveis. Dependendo de sua viabilidade, as células florescem em vede (vivas) ou em vermelho (mortas) (Haugland, 1996). Para uma gentil separação das células dos grãos, testes com agitação e sonicação foram realizados e decidiu-se pela agitação. As amostras foram diluídas 10.000 vezes após um período de agitação de 15 min. Dois mililitros das amostras diluídas foram coradas com $3 \mu \mathrm{l}$ de 1:1 dos corantes (6.68 M SYTO 9 e 20 M iodeto propídico) e incubadas por 30 min. em temperatura ambiente. A amostra foi filtrada em filtro policarbonato black de $0,2 \mu \mathrm{m}$ e montada em lâmina. Um total de 400 células por amostra foi contado em microscópio de epifluorescência. 


\subsubsection{Extração do DNA, PCR e DGGE}

Amostras coletadas para análise da comunidade microbiana foram conservadas em congelador a $-20^{\circ} \mathrm{C}$ até análise. A extração de DNA das amostras de sedimento foi realizada utilizando o PowerSoil DNA Isolation Kit (MoBio Laboratories, CA, USA) de acordo com as especificações do fabricante. O DNA extraído foi quantificado e sua pureza checada através de medidas de absorbância com espectrofotômetro.

A região variável V3 do gene 16S do rRNA foi amplificada do DNA extraído usando os primers 338f-GC e 518r para bactéria. A mistura para as reações de PCR em um total de $50 \mu \mathrm{l}$ consistiu de: $2 \mu \mathrm{l}$ de DNA extraído (aproximadamente $20 \mathrm{ng}$ ), $5 \mu \mathrm{l}$ 10X PCR Buffer (Invitrogen), 1,5 $\mu \mathrm{l} \mathrm{MgCl}_{2}$ (50mM), 0,4 $\mu \mathrm{l} \mathrm{dNTP}(100 \mathrm{mM}), 1 \mathrm{U}$ Taq polymerase (Platinum, Invitrogen), água livre de ácido nucleico até completar o volume. O PCR foi realizado através de um termociclador (Eppendorf Mastercycler Personal), nas seguintes condições: $94^{\circ} \mathrm{C}$ por $5 \mathrm{~min}$. seguido por 30 ciclos de $94^{\circ} \mathrm{C}$ por $1 \mathrm{~min}$., $55^{\circ} \mathrm{C}$ por 1 min., e $72^{\circ} \mathrm{C}$ por 2 min., com uma extensão do passo final a $72^{\circ} \mathrm{C}$ por 10 min. Todos os produtos finais de PCR foram checados e quantificados por eletroforese em gel de agarose $1 \%(\mathrm{w} / \mathrm{v})$.

Com intuito de reduzir o número de amostras, os produtos de PCR das réplicas foram misturados antes da aplicação no gel de DGGE (eletroforese em gel com gradiente denaturante). Antes da mistura um DGGE foi realizado com as amostras individuais e mostraram uma aceitável semelhança (dados não apresentados). Na análise de DGGE, foi utilizado um gel de poliacrilamida a $8 \%$, com uma gradiente de denaturação de $25-70 \%$ (100\% denaturante $7 \mathrm{M}$ ureia, e $40 \%$ formamida). Concentrações similares de produto de PCR foram colocadas no gel e a eletroforese foi realizada em tampão TAE $1 \mathrm{X}$ por $16 \mathrm{~h}$ a uma constante de $60 \mathrm{~V}$ a $60{ }^{\circ} \mathrm{C}$, utilizando o sistema Dcode Universal Mutation Detection System (Bio-Rad Laboratories, Richmond Calif.). O gel foi corado com nitrato de prata modificado de Sanguinetti et al. (1994) e a imagem obtida com o auxílio de um escâner.

\subsubsection{Sequenciamento das bandas de DGGE e análise filogenética}

As bandas dominantes e mais intensas do DGGE foram excisadas e incubadas em tris-HCL por $30 \mathrm{~min}$. a $80^{\circ} \mathrm{C}$. Um mililitro do sobrenadante foi usado para reamplificação da banda com PCR igual ao utilizado para o DGGE. A mobilidade do fragmento amplificado foi checada quanto à sua posição repetindo-se o DGGE com 
condições idênticas ao original. O sequenciamento foi conduzido usando o BigDye Terminator v3.1 Cycle Sequencing Kit (Applied Biosystems) pela empresa Genomics Engenharia Molecular, usando o primer 518r. As sequências de DNA foram editadas com o programa Bio-Edit Sequence Alignment Editor e alinhadas com o programa Clustal W software (http://www.ebi.ac.uk/clustalw). As sequências foram comparadas com aquelas depositadas no GenBank usando o algoritmo Blast (http://www.ncbi.nlm.nih.gov/BLAST).

\subsubsection{Análises estatísticas}

As variáveis foram analisadas quanto à normalidade usando o teste Kolmogorov-Smirnov. As diferenças entre tratamento e controle e entre os tempos amostrados das variáveis obtidas foram testadas a partir de análises de variância (ANOVA one-way ou Kruskal-Wallis). Relações entre as variáveis foram testadas através do teste de correlação de Pearson $(n=13)$. Uma Análise de Componentes Principais (PCA; CANOCO 4.5 e Canodraw 4.5; Ter Braak \& Smilauer, 2002) foi conduzida com os fatores abióticos (13 amostras; 6 variáveis). Foi realizada uma Análise de Redundância Canônica (RDA; Canoco 4.5; Ter Braak \& Smilauer, 2002) para avaliar a influência dos fatores abióticos na abundância de procariotos. A densidade total dos procariotos e a densidade de vivos foram utilizadas como a matriz resposta (13 amostras; 2 variáveis) e os parâmetros abióticos como matriz explanatória (13 amostras; 6 variáveis).

O DGGE foi analisado através do programa BioNumerics 6.1 (AppliedMaths). Um dendograma foi construído através do coeficiente de similaridade de Dice e pela análise de agrupamento pelo método da distância média não ponderada (UPGMA).

Com o objetivo de estabelecer qual variável melhor explica o perfil de bandas do DGGE, uma Análise de Correspondência Canônica (CCA, CANOCO 4.5) foi realizada. A significância estatística das relações entre a diversidade genética (DGGE) e as variáveis bióticas e abióticas foi avaliada através do teste de Monte Carlo (9999 permutações). Para a CCA foram adicionados às variáveis os dados de fluxo de nutrientes (Godoi, et al., em preparação). 


\subsection{Resultados}

\subsubsection{Variáveis abióticas}

O consumo de oxigênio aumentou em ambos, controle e tratamento após o início do experimento (Figura 3.1), apresentando um maoir consumo de oxigênio após 48 h. Não foram observadas diferenças significativas entre os fluxos de oxigênio durante o experimento temporalmente, e, apenas no tempo de $480 \mathrm{~h}$ após a ressuspensão, foram observadas diferenças significativas entre tratamento e controle.

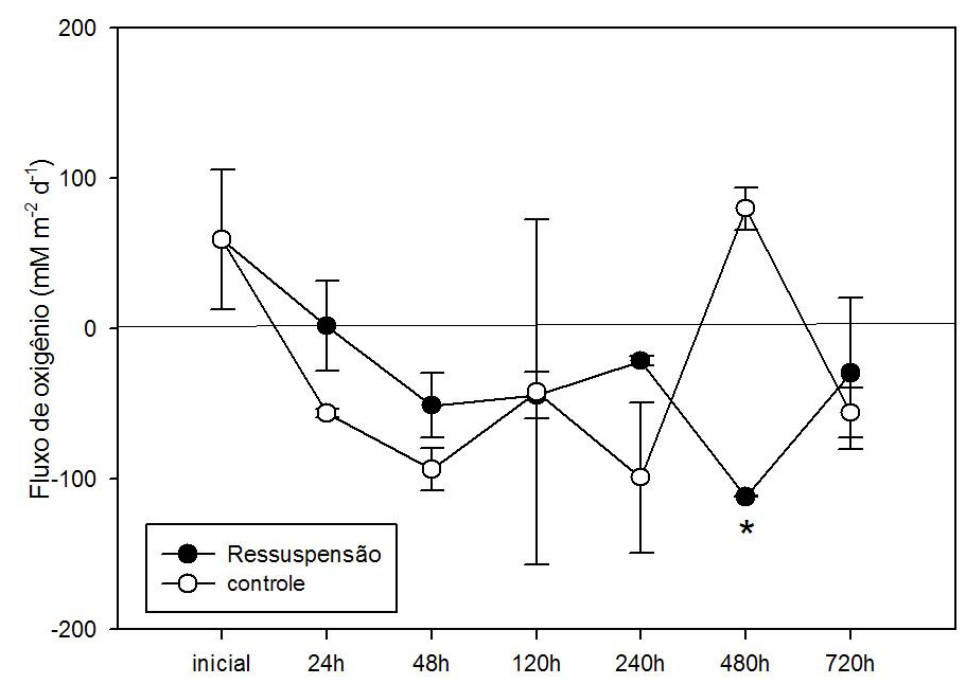

Figura 4.1: Fluxo de oxigênio $\left(\mathrm{mM} \mathrm{m}^{-2} \mathrm{~d}^{-1}\right)$ através da interface sedimento-água e (média \pm erro padrão) ao longo do tempo experimental. ( ${ }^{*} \mathrm{p}<0.05$, ANOVA, Tukey).

Os valores de MOT e COT não foram significativamente diferentes após a ressuspensão do sedimento (Figura 3.2a,b). De um modo geral, a concentração de MOT aumentou após a ressuspensão, diminuindo após 120 h. O mesmo padrão ocorreu no controle, que apresentou seus menores valores $480 \mathrm{~h}$ após o inicio do experimento (Figura 3.2a). O COT diminuiu logo após o evento de ressuspensão, porém, o padrão oposto foi observado para o controle (Figura 3.2b).

A clorofila-a aumentou $11 \%$ após o evento de ressuspensão e diminuiu gradativamente até o final do experimento. Contudo, não houve diferenças temporais significativas (Figura 4a). No experimento controle houve um aumento gradativo nos valores de clorofila-a, com concentrações significativamente maiores do que as encontradas no tratamento após $240 \mathrm{~h}$ do início do experimento (Figura 4a). Já as concentrações de feopigmentos não apresentaram diferenças significativas entre 
tratamento e controle ou temporalmente (Figura 4b). De uma forma geral, os feopigmentos variaram pouco após o evento de ressuspensão, enquanto que no controle observou-se um aumento nas concentrações de feopigmentos $48 \mathrm{~h}$ após o início do experimento, com diminuição gradativa até o final do experimento (Figura 4b).
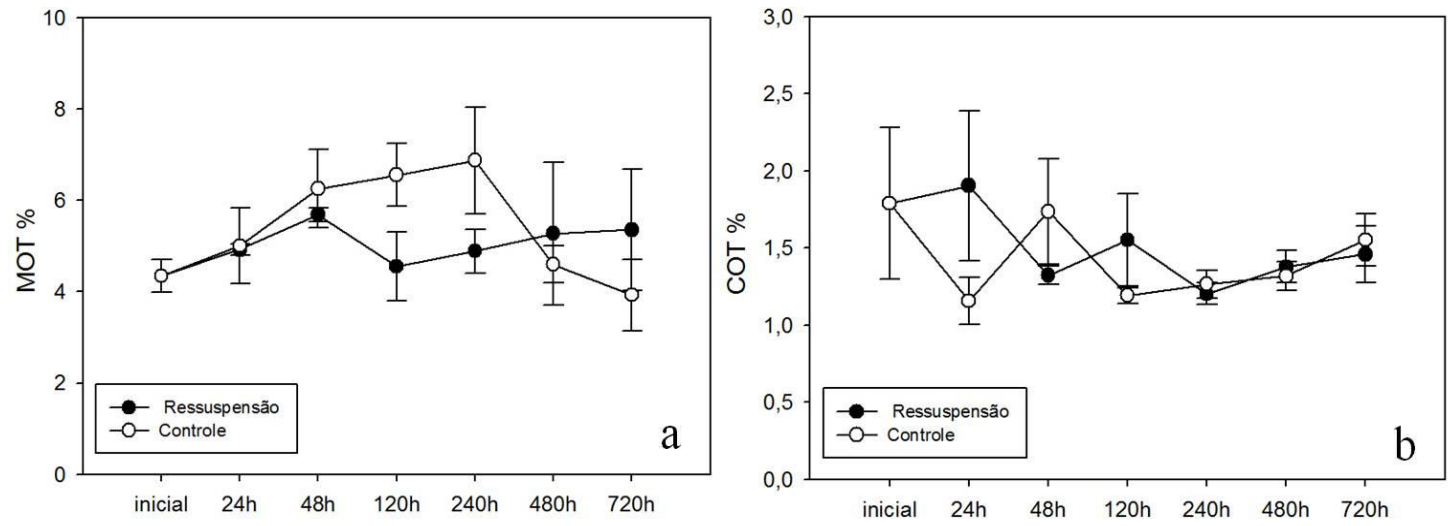

Figura 4.2: Valores de (a) material orgânico total (MOT) e (b) carbono orgânico total (COT) na primeira camada $(0-1 \mathrm{~cm})$ (média \pm erro padrão) ao longo do experimento (horas) $(* \mathrm{p}<0.05$, ANOVA, Tukey).
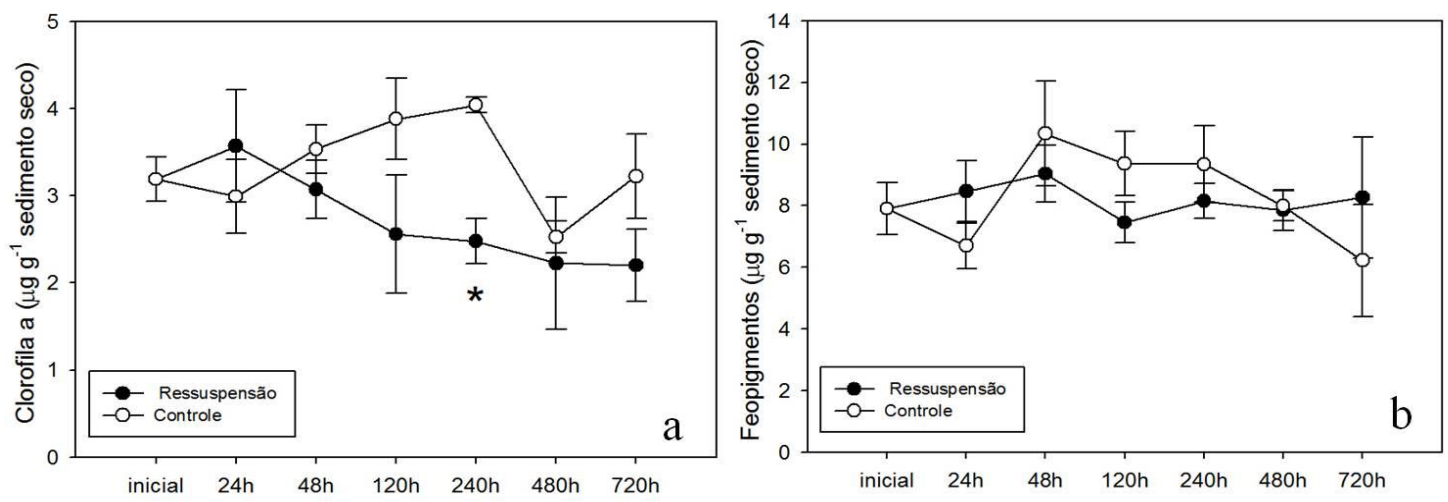

Figura 4.3: Distribuição dos fitopigmentos (média \pm erro padrão) na primeira camada sedimentar $(0-1 \mathrm{~cm})$ ao longo do experimento (horas) $(* \mathrm{p}<0.05$, ANOVA, Tukey). (a) clorofila-a; (b) feopigmentos.

A análise de correlação de Pearson mostrou uma correlação positiva entre os valores de feopigmentos e MOT $(\mathrm{r}=0,823 ; \mathrm{p}<0,000)$. Com um intuito de comparar os tratamentos nos períodos amostrados, baseado nas características sedimentares uma PCA foi feita com todas as variáveis abióticas (Figura 3.4). Os resultados indicaram que os dois primeiros eixos explicaram 78,3\% da variação observada. O eixo 1 explicou $54,4 \%$ da variação e separou as amostras principalmente quanto a quantidade de clorofila-a, feopimentos e MOT, e consumo de oxigênio (Figura 3.4). O eixo 2 explicou 
23,9\% da variação e separou as amostras principalmente quanto a quantidade de COT (Figura 3.4).

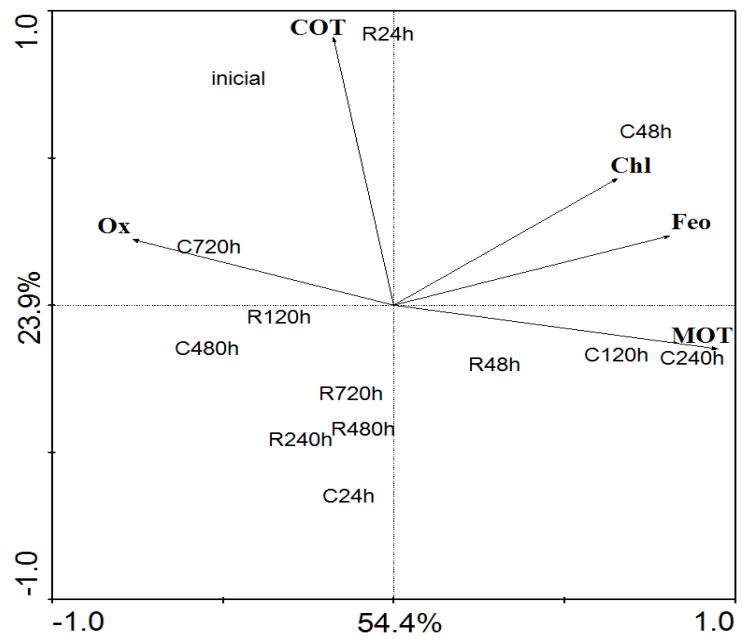

Figura 4.4: Análise de Componentes Principais (PCA) das variáveis abióticas encontradas durante $\mathrm{o}$ período experimental. $\mathrm{R}=$ tratamento com ressuspensão; $\mathrm{C}=$ controle; $\mathrm{Chl}=$ clorofila $-\mathrm{a} ; \mathrm{Feo}=$ feopigmentos; $\mathrm{Ox}=$ fluxo de oxigênio.

\subsubsection{Densidade de procariotos}

A densidade total de procariotos e de procariotos vivos aumentou significativamente $24 \mathrm{~h}$ após o inicio do experimento em ambos, controle e tratamento com ressuspensão (Tabela 1, Figura 3.5a, b). Os valores encontrados após 120 h e 240 $\mathrm{h}$ foram significativamente maiores do que no controle (Figura 3.5a, b). No controle, a densidade de procariotos vivos e total diminuiu após o aumento de $24 \mathrm{~h}$, voltando a aumentar significativamente após 480 h e 720 h de experimento (Tabela 1, Figura 3.5a, b). As células vivas foram mais abundantes do que no tratamento após 480 h (Figura $3.5 b)$.

Houve correlação significativa entre as densidades de procariotos total e vivos e a clorofila-a $(\mathrm{r}=-0,720, \mathrm{p}=0,005 ; \mathrm{r}=-0,747, \mathrm{p}=0,003$, respectivamente $) . \mathrm{Na}$ análise de RDA, a clorofila-a foi a única variável que explicou significativamente a densidade total e de procariotos vivos, explicando 53,9\% da variação dos dados apenas no primeiro eixo (Figura 3.6). 

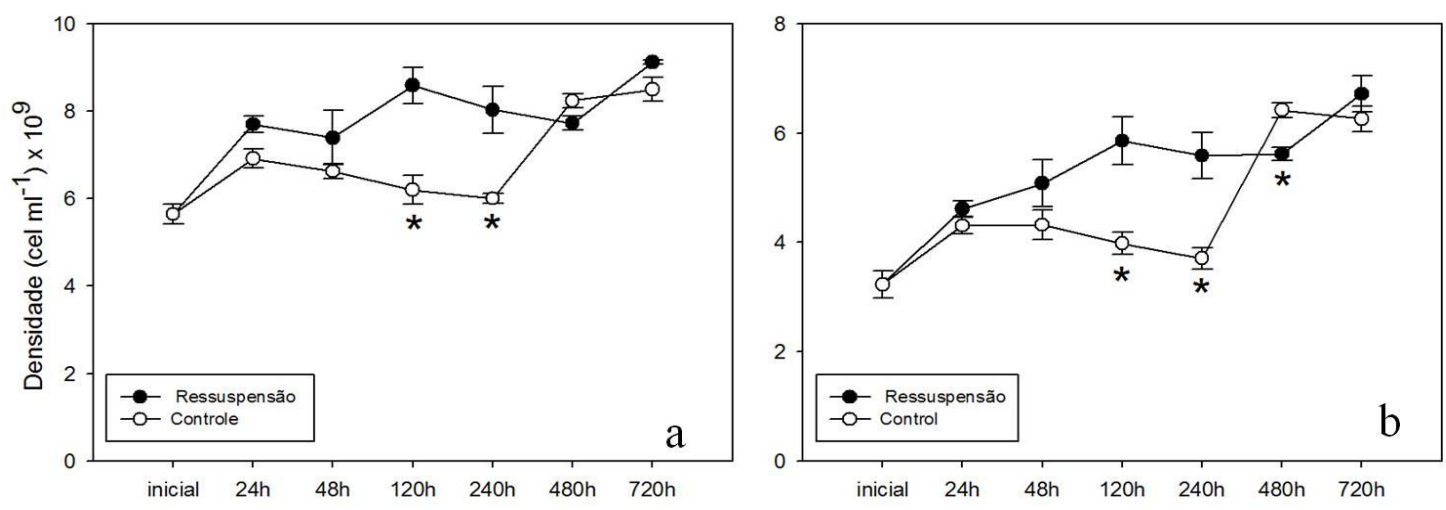

Figura 4.5: Densidade de procariotos (a) e densidade de células vivas (b) (média \pm erro padrão) na camada superficial $(0-1 \mathrm{~cm})$ do sedimento ao longo do experimento. $(* \mathrm{p}<0,05$, ANOVA, Tukey).

Tabela 4.1: Análise de Variância (ANOVA) dos valores de densidade total e de células vivas na camada superficial durante o período do experimento.

\begin{tabular}{|c|c|c|c|c|}
\hline & \multicolumn{2}{|c|}{ Densidade Total } & \multicolumn{2}{|c|}{ Densidade vivos } \\
\hline & $\mathrm{p}$ & Tukey $(\mathrm{p}<0.05)$ & $\mathrm{p}$ & Tukey $(\mathrm{p}<0.05)$ \\
\hline Ressuspensão & 0,00 & $\begin{array}{l}\text { inicial } \neq 24 \mathrm{~h}, 120 \mathrm{~h}, 240 \mathrm{~h}, \\
480 \mathrm{~h}, 720 \mathrm{~h}\end{array}$ & 0,00 & $\begin{array}{l}\text { inicial } \neq 24 \mathrm{~h}, 120 \mathrm{~h}, 240 \mathrm{~h}, 480 \mathrm{~h}, \\
720 \mathrm{~h} ; 720 \mathrm{~h} \neq 24 \mathrm{~h}, 48 \mathrm{~h}\end{array}$ \\
\hline Controle & 0,00 & $\begin{array}{l}\text { inicial } \neq 24 \mathrm{~h} ; 480 \mathrm{~h}, \\
720 \mathrm{~h} \neq \text { inicial, } 24 \mathrm{~h}, 48 \mathrm{~h}, \\
120 \mathrm{~h}, 240 \mathrm{~h}\end{array}$ & 0,00 & $\begin{array}{l}\text { inicial } \neq 24 \mathrm{~h}, 48 \mathrm{~h} ; 480 \mathrm{~h}, \\
720 \mathrm{~h} \neq \text { inicial, } 24 \mathrm{~h}, 48 \mathrm{~h}, 120 \mathrm{~h}, \\
240 \mathrm{~h}\end{array}$ \\
\hline
\end{tabular}

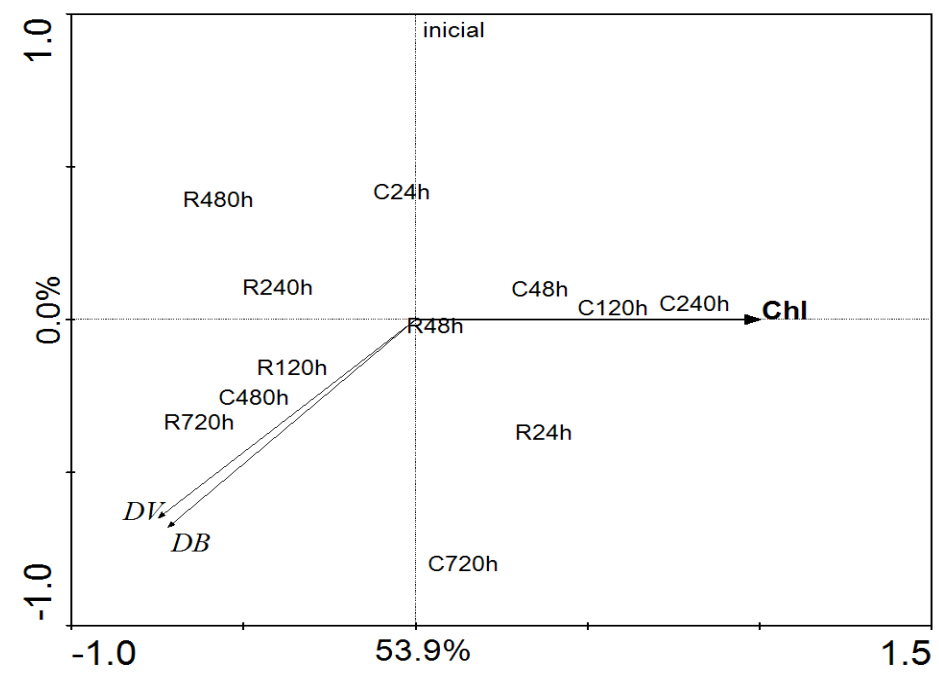

Figure 4.6: Análise de redundância (RDA) observando a influência das variáveis abióticas ( $\mathrm{n}=19,5$ variáveis) na densidade de procariotos ( $\mathrm{n}=19,2$ variáveis). 


\subsubsection{DGGE e diversidade bacteriana}

A técnica de DGGE foi aplicada usando fragmentos 16S do rRNA para análise da comunidade bacteriana durante o período experimental. Os padrões de DGGE mostraram mudanças na comunidade bacteriana após a ressuspensão e com o tempo experimental (Figura 4.7). Foram observadas entre 42 e 56 bandas nas amostras de sedimento, sendo que o tratamento apresentou maior número de bandas do que o controle após o evento de ressuspensão (Figura 4.8). Após 48 h da ressuspensão, o número de bandas aumentou $33 \%$ em relação aos valores iniciais, diminuindo gradativamente até o fim do experimento (Figura 4.8). A análise de agrupamento UPGMA mostrou mudanças na comunidade principalmente com relação ao tempo de experimento, e separou a comunidade em quatro grupos com mais de $85 \%$ de semelhança (Figura 4.9). O primeiro grupo foi formado pela amostra inicial, e ressuspensão e controle $24 \mathrm{~h}$, o segundo grupo foi formado pelo ressuspensão e controle 48h, e ressuspensão $120 \mathrm{~h}$, o terceiro agrupou as amostras do controle $120 \mathrm{~h} \mathrm{e}$ ressuspensão 240 h, o quarto grupo foi formado pelo controle $240 \mathrm{~h}$ e as amostras de 480 h e 720 h (Figura 4.9).

Os dois primeiros eixos da CCA explicaram apenas $25,1 \%$ do padrão das bandas do DGGE (Figura 4.10a). Os dados de densidade de procariotos vivos e fluxo de nitrogênio inorgânico dissolvido (NID, Godoi, em preparação) foram as únicas variáveis que mostraram influência significativa no padrão de variação da comunidade bacteriana, mostrando uma maior mudança da comunidade logo após a ressuspensão (R24 h e 48 h) (Figura 4.10a). Para observar a influência de todas as variáveis na comunidade bacteriana, uma CCA com todas as variáveis foi aplicada e explicou apenas $28,5 \%$ da variação nos primeiros dois eixos (Figura 4.10b). 


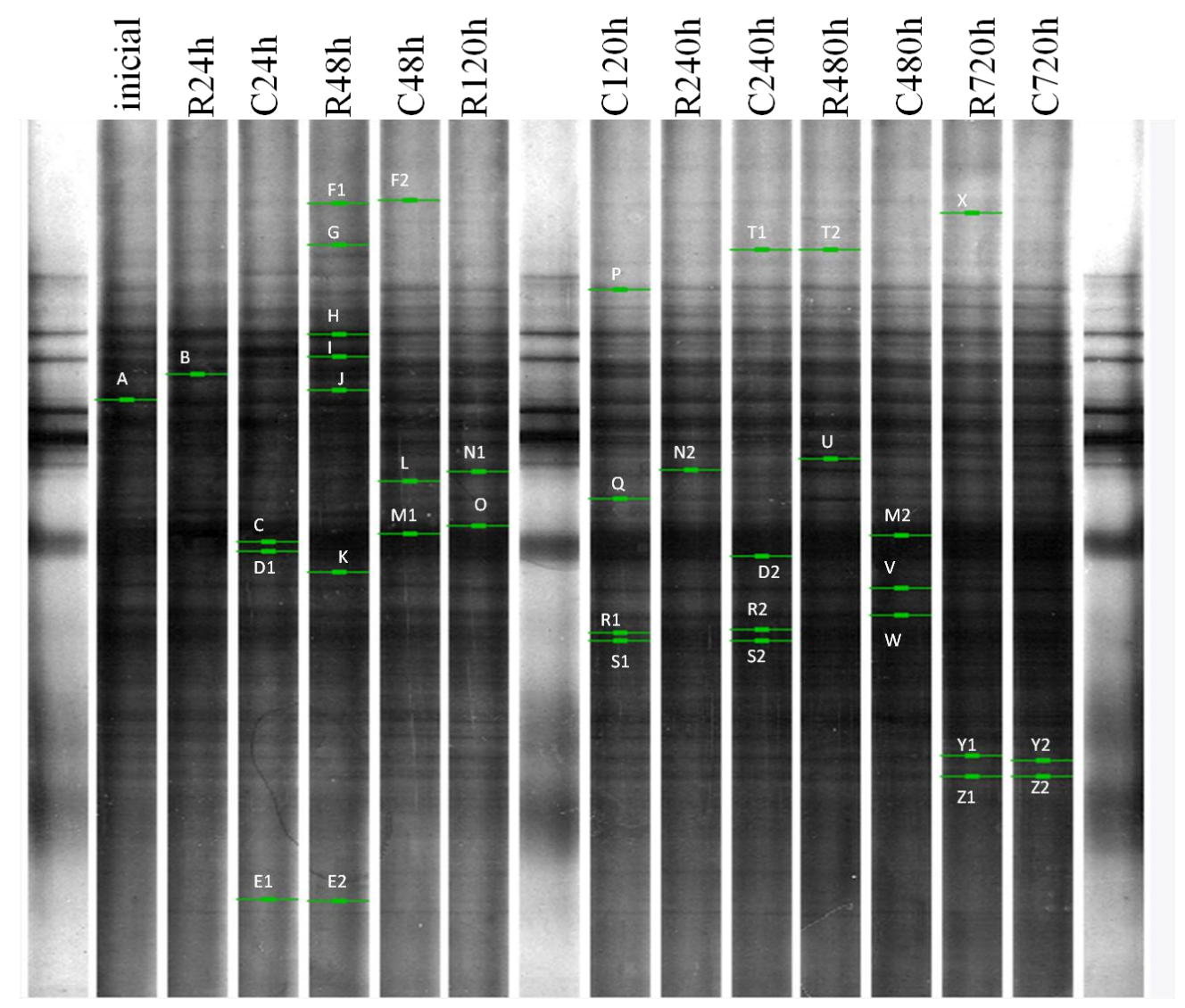

Figura 4.7: Estrutura da comunidade bacteriana representada em um gel de DGGE (25-70\%) do gene $16 \mathrm{~S}$ do rRNA (338f-GC e 518r ) extraído da primeira camada do sedimento. Letras indicam as bandas cortadas e sequenciadas. $\mathrm{R}=$ ressuspensão, $\mathrm{C}=$ controle.

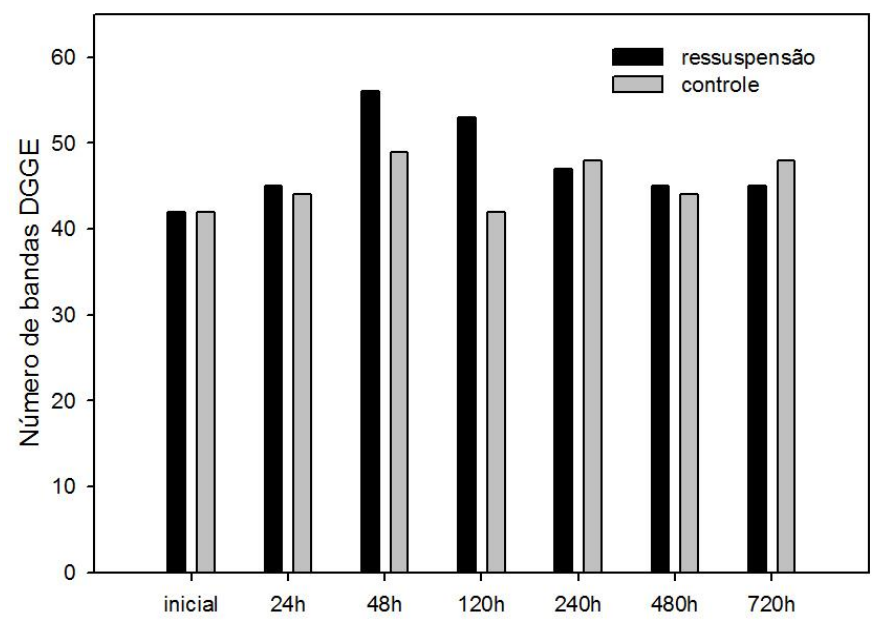

Figura 4.8: Número de bandas identificadas no gel de DGGE da comunidade bacteriana. 


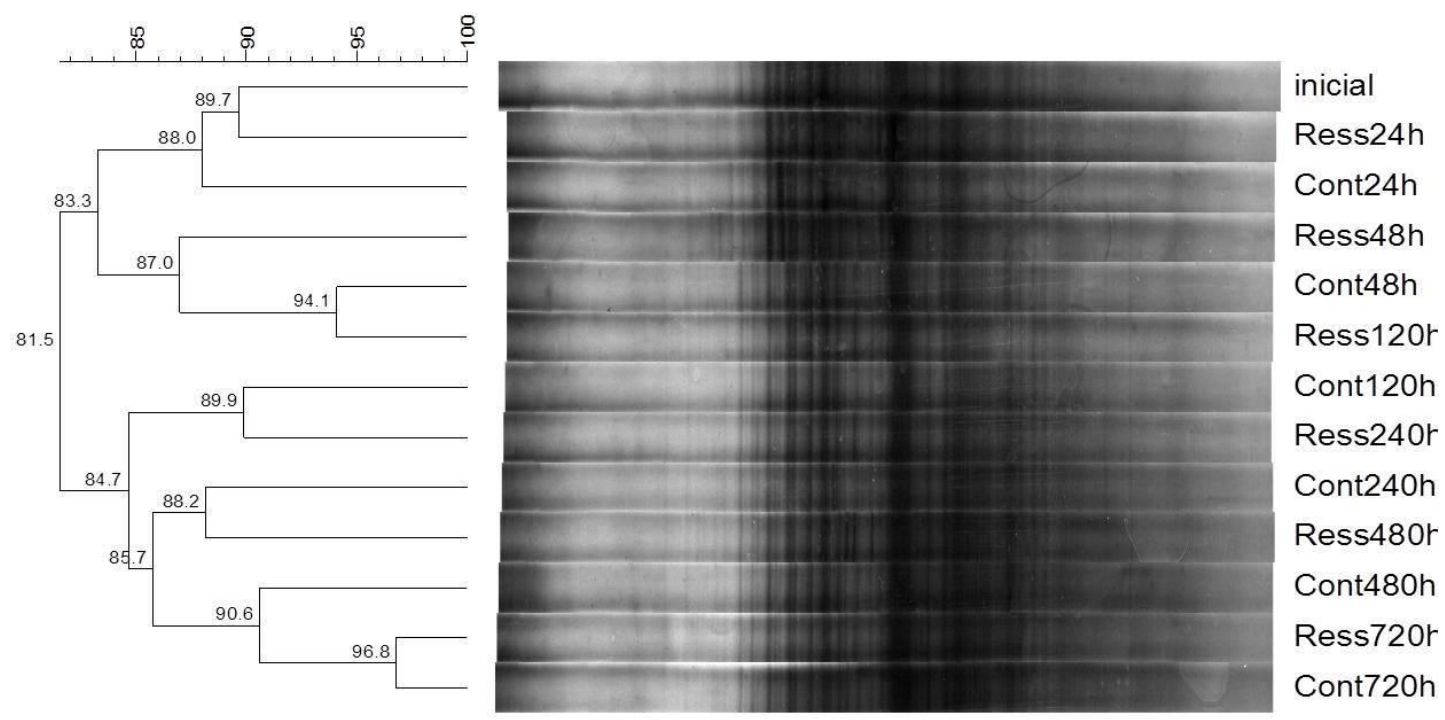

Figura 4.9: Análise de agrupamento do padrão de bandas de DGGE das bactérias sedimentares usando a análise UPGMA. Matriz de similaridade calculada usando DICE.
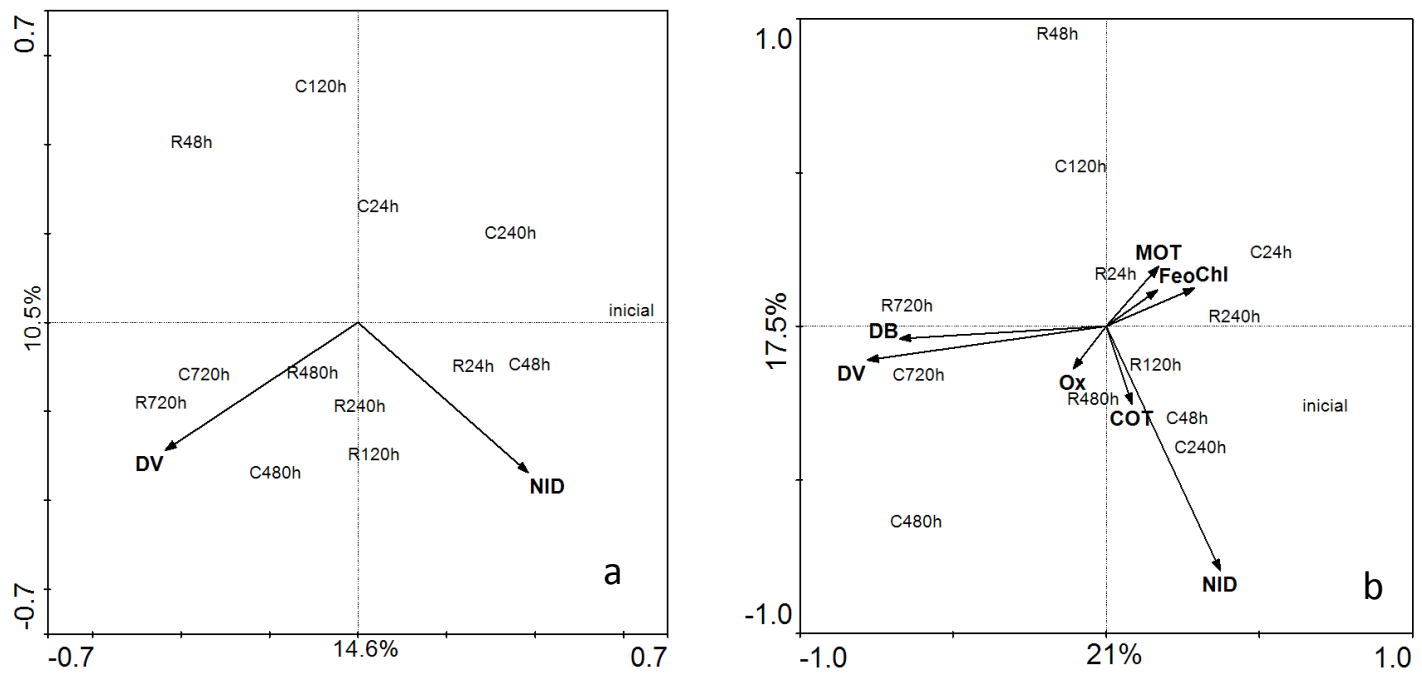

Figura 4.10: Análise de correspondência canônica (CCA) usando os perfis de PCR-DGGE das amostras do sedimento e as variáveis sedimentares medidas a. CCA mostrando apenas as variáveis significativas de acordo com o teste de Monte Carlo $(\mathrm{p}<0.05)$ b. CCA mostrando a influência de todas as variáveis.

O sequenciamento parcial de 36 bandas excisadas a partir de perfis de DGGE foi determinado (Figura 3.7) e o mais próximo organismo relacionado foi determinado, exibindo semelhança superior a $80 \%$ em todas as sequências (Tabela 3.2). A maioria das bandas pôde ser atribuída à Gammaproteobacteria e Deltaproteobacteria, representando mais de $50 \%$ das bandas sequenciadas. Foram encontrados também organismos pertencentes aos grupos Bacterioidetes, Firmicute, Alpha- e Beta- 
proteobacteria, Actynobacteria, Cyanobacteria e Aquificae, mostrando a alta diversidade encontrada nas amostras (Tabela 2.3). Treze bandas sequenciadas ocorreram em todas as amostras, sendo encontrado entre elas representante de praticamente todos os grupos. Cinco bandas apareceram em menos de cinco amostras $(\mathrm{C}, \mathrm{G}, \mathrm{J}, \mathrm{L}$ e $\mathrm{X})$, as bandas $\mathrm{C}$ e $\mathrm{X}$ foram designadas como Deltaproteobacteria, e ocorreram principalmente nas amostras onde a ressuspensão foi realizada (Tabela 2.3, Figura 3.7). As bandas L e J, atribuídas como Gammaproteobacteria, ocorreram principalmente no início do experimento. A banda $G$ foi a única atribuída a Actinobacteria, e ocorreu em R48h e nas amostras após 720 h de experimento (Tabela 2.3, Figura 3.7). 
Tabela 4.2: Afiliação filogenética dos genótipos detectados na primeira camada sedimentar das amostras experimentais sequenciadas a partir das bandas de DGGE.

\begin{tabular}{|c|c|c|c|c|}
\hline Banda & $\begin{array}{l}\text { N. total de } \\
\text { bandas } \\
\text { encontradas }\end{array}$ & Sequências com relação mais próxima e no. de acesso do GenBanK & \% similaridade & Afiliação filogenética \\
\hline A & 13 & $\begin{array}{l}\text { ref|NR_040977.1| Desulfobulbus japonicus strain Pro1 (= JCM 14043, = DSM 18378) 16S ribosomal } \\
\text { RNA, partial sequence }\end{array}$ & 96 & Deltaproteobacteria \\
\hline B & 13 & ef|NR_041955.1| Roseospirillum parvum strain 930I 16S ribosomal RNA, partial sequence & 93 & Alphaproteobacteria \\
\hline $\mathrm{C}$ & 4 & ref|NR_044940.1| Hippea maritima DSM 10411 strain MH2 16S ribosomal RNA, partial sequence & 100 & Deltaproteobacteria \\
\hline $\mathrm{D} 1,2$ & 11 & ref|NR_042399.1| Thiorhodococcus mannitoliphagus strain : WS 16S ribosomal RNA, partial sequence & 87 & Gammaproteobacteria \\
\hline $\mathrm{E} 1,2$ & 13 & ref|NR_044318.1| Simiduia agarivorans strain SA1 16S ribosomal RNA, partial sequence & 81 & Gammaproteobacteria \\
\hline $\mathrm{F} 1,2$ & 13 & ref|NR_044565.1| Mucilaginibacter ximonensis strain XM-003 16S ribosomal RNA, partial sequence & 100 & Bacteroidetes \\
\hline G & 4 & ref|NR_025220.1| Rubrobacter taiwanensis strain LS-293 16S ribosomal RNA, partial sequence & 96 & Actinobacteria \\
\hline $\mathrm{H}$ & 13 & ref|NR_025456.1| Oceanicaulis alexandrii strain C116-18 16S ribosomal RNA, partial sequence & 91 & Alphaproteobacteria \\
\hline I & 13 & ref|NR_025094.1| Kushneria marisflavi strain SW32 16S ribosomal RNA, partial sequence & 90 & Gammaproteobacteria \\
\hline & 3 & ref|NR_025800.1| Marinobacter daepoensis strain SW-156 16S ribosomal RNA, partial sequence & 95 & Gammaproteobacteria \\
\hline & 7 & ref|NR_043109.1| Alcanivorax balearicus strain MACL04 16S ribosomal RNA, complete sequence & 93 & Gammaproteobacteria \\
\hline & 5 & ref|NR_043140.1| Psychrobacter aquimaris strain SW-210 16S ribosomal RNA, partial sequence & 98 & Gammaproteobacteria \\
\hline M1,2 & 13 & $\begin{array}{l}\text { ref|NR_044104.1| Rubidibacter lacunae KORDI 51-2 strain KORDI 51-2 16S ribosomal RNA, partial } \\
\text { sequence }\end{array}$ & 89 & Cyanobacteria \\
\hline $\mathrm{N} 1,2$ & 10 & ref|NR_044457.1| Marinobacter zhejiangensis strain CN74 16S ribosomal RNA, partial sequence & 95 & Gammaproteobacteria \\
\hline 0 & 7 & $\begin{array}{l}\text { ref|NR_027533.1| Dyadobacter fermentans DSM } 18053 \text { 16S ribosomal RNA, partial sequence } \\
\text { Length=1393 }\end{array}$ & 87 & Bacteroidetes \\
\hline $\mathrm{P}$ & 12 & ref|NR_025980.1| Piscirickettsia salmonis strain LF-89 16S ribosomal RNA, complete sequence & 84 & Gammaproteobacteria \\
\hline Q & 13 & ref|NR_024657.1| Marinospirillum minutulum strain ATCC 19193 16S ribosomal RNA, partial sequence & 90 & Gammaproteobacteria \\
\hline $\mathrm{R} 1,2$ & 11 & ref|NR_026154.1| Pelobacter acidigallici strain DSM 2377 16S ribosomal RNA, partial sequence & 94 & Deltaproteobacteria \\
\hline $\mathrm{S} 1,2$ & 7 & $\begin{array}{l}\text { ref|NR_042432.1| Desulfomonile tiedjei DSM } 6799 \text { strain DSM } 6799 \text { 16S ribosomal RNA, partial } \\
\text { sequence }\end{array}$ & 87 & Deltaproteobacteria \\
\hline $\mathrm{T} 1,2$ & 6 & ref|NR_037008.1| Desulfotomaculum australicum strain AB33 16S ribosomal RNA, partial sequence & 88 & Firmicute \\
\hline $\mathrm{U}$ & 7 & ref|NR_025839.1| Rhodocyclus tenuis strain 2761 16S ribosomal RNA, partial sequence Length=1460 & 88 & Betaproteobacteria \\
\hline $\mathrm{V}$ & 13 & ref|NR_043575.1| Geobacter argillaceus strain G12 16S ribosomal RNA, partial sequence & 88 & Deltaproteobacteria \\
\hline W & 13 & ref|NR_042814.1| Desulfurobacterium pacificum strain SL17 16S ribosomal RNA, partial sequence & 90 & Aquificae \\
\hline $\mathrm{X}$ & 2 & $\begin{array}{l}\text { ref|NR_040977.1| Desulfobulbus japonicus strain Pro1 (= JCM 14043, = DSM 18378) 16S ribosomal } \\
\text { RNA, partial sequence }\end{array}$ & 92 & Deltaproteobacteria \\
\hline $\mathrm{Y} 1,2$ & 13 & $\begin{array}{l}\text { ref|NR_029146.1| Sedimentibacter hydroxybenzoicus strain JW/Z-1 16S ribosomal RNA, partial } \\
\text { sequence }\end{array}$ & 91 & Firmicute \\
\hline $\mathrm{Z} 1,2$ & 13 & ref|NR_044441.1| Aestuariicola saemankumensis strain SMK-142 16S ribosomal RNA, partial sequence & 90 & Bacteroidetes \\
\hline
\end{tabular}




\subsection{Discussão}

4.4.1. Efeito da ressuspensão no consumo de oxigênio e parâmetros sedimentares

Vários estudos onde a ressuspensão do sedimento foi simulada ou ocorreu naturalmente em campo mostraram um aumento no consumo do oxigênio após esse evento (Bussmann et al., 2001; Almroth et al., 2009). No presente estudo, o fluxo de oxigênio aumentou após o evento de ressuspensão quando comparado com os valores iniciais, porém o consumo foi menor do que o apresentado pelo controle sem ressuspensão (Figura 2.1).

Tengberg et al. (2003) também observou uma diminuição no consumo de oxigênio após eventos de ressuspensão simulados em campo. Nesse caso, a diminuição no consumo de oxigênio foi atribuída a uma menor taxa de remineralização do carbono orgânico, devido à baixa atividade dos organismos encontrados no local na época do ano estudada (inverno) e diluição da matéria orgânica. Nossos resultados não mostraram baixas atividades microbianas, porém o efeito mecânico direto da ressuspensão nos micro-organismos, somado à diluição do material orgânico que foi suspenso na água sobrejacente, pode explicar a diminuição no consumo de oxigênio. Locais ricos em matéria orgânica apresentam respostas mais acentuadas aos eventos de ressuspensão naturais e/ou antrópicas (Sloth et al., 1996; Almroth et al., 2009; Almroth-Rosell et al., 2012). Por outro lado, sedimentos que apresentam baixa concentração de matéria orgânica parecem apresentar um pequeno aumento ou diminuição no consumo do oxigênio após eventos de ressuspensão (Tenberg, 2003; Almroth-Rosell et al., 2012). Como no presente estudo, nestes casos o resultado da diluição da matéria orgânica leva a uma menor taxa de remineralização em todo o sistema sedimento-água, em comparação com o sistema onde a ressuspensão não foi realizada.

Os resultados de MOT não mostraram resposta significativa ao evento de ressuspensão. No entanto, os valores de COT, clorofila-a e feopigmentos aumentaram logo após a ressuspensão, diminuindo com o tempo, tanto em relação aos valores iniciais quanto ao controle. Eventos de ressuspensão resultam em uma redistribuição dos sedimentos superficiais e mistura da MO dentro da coluna sedimentar, redisponibilizando a matéria orgânica das camadas mais profundas para as camadas superficiais do sedimento (Ståhlberg et al., 2006). 


\subsubsection{Efeito da ressuspensão na comunidade microbiana do sedimento}

Todos os fatores que induzem a ressuspensão sedimentar podem ter efeitos significativos no ambiente bêntico. Porém, informações sobre a resposta da comunidade microbiana a ressuspensão e retrabalhamento sedimentar são muito escassas (Chròst \& Riemann, 1994; Fiordelmondo \& Pusceddu, 2004; Pusceddu et al., 2005). As investigações disponíveis indicam que a ressuspensão pode afetar os organismos bênticos e as interações entre os componentes microbianos dentro da cadeia trófica microbiana (Garstecki \& Wickham, 2001; Fiordelmondo et al., 2003; Polymenakou et al., 2005b).

De um modo geral, a densidade procariótica aumentou com o tempo experimental, sendo mais pronunciada após a ressuspensão do sedimento, principalmente, $120 \mathrm{~h}$ após o evento de ressuspensão (Figura 3.5). O padrão observado pode ser o resultado de dois fatores: (1) durante a ressuspensão ocorre o desalojamento de uma fração dos micro-organismos do sedimento para a coluna d'água, determinando uma redução imediata na abundância microbiana; (2) após a ressuspensão certa fração de micro-organismos redeposita, somando a fração microbiana já presente no sedimento, passando a crescer em resposta à condição propícia criada, voltando a aumentar sua abundância no sedimento. Resultados similares aos encontrados foram reportados para bactérias e protistas expostos à ressuspensão tanto em ambientes naturais com em microcosmos (Shimetta et al., 2003; Horner-Devine et al., 2004; Polymenakou et al., 2005b; Pusceddu et al., 2005).

Apenas uma fração do total de procariotos nas contagens diretas é representada por micro-organismos ativos metabolicamente. Neste estudo, a fração de procariotos considerados ativos metabolicamente (em média $60 \%$ da abundância total) apresentou respostas semelhantes aos da densidade total ao evento de ressuspensão. Desta forma, a ressuspensão aumenta a densidade de células ativas metabolicamente, estimulando o crescimento da população microbiana do sedimento. De fato, o aumento na atividade bacteriana e das taxas de decomposição da matéria orgânica tem sido documentado após eventos de ressuspensão moderada (Cotner et al., 2000; Fiordelmondo \& Pusceddu, 2004; Pusceddu et al., 2005). Tais efeitos de estímulo na comunidade microbiana podem ser explicados por vários fatores concomitantes, entre eles um aumento na disponibilidade de recursos na camada superficial do sedimento das camadas mais profundas, a abertura de espaço para a colonização e crescimento microbiano devido à 
redução da pressão de predação por nanobentos heterotróficos, que parecem ser altamente impactados por eventos de ressuspensão (Findlay et al., 1990; Watling et al., 2001; Fiordelmondo et al., 2003; Polymenakou et al., 2005b).

Mudanças na comunidade bacteriana após a ressuspensão foram observadas principalmente nos primeiros dias após o evento. Aparentemente o distúrbio aplicado ao sedimento foi responsável por um atraso no padrão de mudança da comunidade com o tempo, observado no controle. $\mathrm{O}$ aumento na densidade de procariotos vivos e aumento na liberação de nitrogênio dissolvido foram as principais variáveis que influenciaram as mudanças na comunidade bacteriana, mostrando que mudanças nas taxas de remineralização da matéria orgânica foram importantes para as variações da comunidade. O ciclo do nitrogênio é um dos mais importantes em regiões costeiras marinhas por serem essas áreas geralmente limitadas pela concentração de nitrogênio inorgânico dissolvido (Sun et al., 2012), como é o caso da área estudada (Gaeta et al., 1999). Dessa forma, a ressuspensão parece alterar a liberação de nitrogênio para a coluna de água, como resultado também de mudanças nos processos bacterianos ocorrendo no sedimento. Essas mudanças, por sua vez, afetam as taxas de reciclagem dos nutrientes no sedimento. Vários estudos vêm demonstrando que eventos de ressuspensão são responsáveis por um aumento nas taxas de decomposição da matéria orgânica, aumentando as taxas metabólicas das bactérias (Tengberg et al., 2003; Ståhlberg et al., 2006). O presente estudo mostra que esses fatores também influenciam a estrutura da comunidade e podem ser responsáveis por mudanças na comunidade bacteriana do sedimento. Adicionalmente, Findlay et al. (1990) demonstraram que bactérias de diferentes grupos funcionais respondem de forma diferente a distúrbios aplicados ao sedimento. Grupos aeróbicos parecem ser mais susceptíveis ao distúrbio do que os grupos anaeróbicos, levando então a mudanças na estrutura da comunidade.

O aumento da diversidade bacteriana observado após a ressuspensão pode estar relacionado ao aumento da oxigenação do sedimento, aumento da matéria orgânica lábil, diminuição da competição devido a uma maior diluição dos micro-organismos no sedimento e diminuição da força de predação, são causados pela ressuspensão moderada do sedimento e são responsáveis por aumentar a diversidade de organismos bênticos (Findlay et al., 1990; Garstecki and Wickhan, 2001; Fukami \& Morin 2003). A alta diversidade da comunidade foi também observada nas bandas sequenciadas, que mostraram representantes de vários grupos taxonômicos que são normalmente encontrados em sedimentos marinhos. 
Gammaproteobactéria foi o grupo dominante nas amostras sequenciadas, confirmando que esse filo parece ser o mais representativo nos sedimentos superficiais da região de Ubatuba. Esse grupo é conhecido por ser bem versátil metabolicamente e é altamente encontrado em sedimentos marinhos de vários locais (Madigan et al., 1997; Zeng et al., 2005; Lai et al., 2006; Chipman et al., 2010). Deltaproteobactéria foi o segundo grupo mais encontrado nas bandas sequenciadas. A maioria das Deltaproteobacteria é redutora de sulfato, um dos metabolismos mais importantes nos sedimentos marinhos que ocorrem em condições anaeróbicas (López-García et al., 2003; Ravenschlag et al., 2000). Tanto as deltaproteobactérias como os firmicutes sequenciados foram atribuídos a organismos redutores de sulfato, o que é condizente com outros estudos em sedimentos marinhos, que mostram que esses grupos são muito representativos em ambientes bênticos (Feng et al., 2009; Pachiadaki et al., 2010; Du et al., 2011). Apesar de esses organismos serem encontrados principalmente em regiões de sedimento anóxico, no presente trabalho eles foram encontrados na primeira camada do sedimento, uma região óxica. Isso está provavelmente associado à ressuspensão do sedimento, trazendo organismos das camadas mais profundas para a camada superficial. Membros dos grupos Bacterioidetes, Alpha- e Beta- proteobacteria, Actynobacteria, Cyanobacteria e Aquificae também foram identificados nas amostras sequenciadas e são grupos normalmente encontrados nos sedimentos marinhos em várias regiões (Ikenaga et al., 2010; Du et al., 2011; Kan et al., 2011).

Resumidamente, a ressuspensão do sedimento foi responsável por mudanças significativas na comunidade microbiana do sedimento. Os procariotos foram estimulados pelo evento de ressuspensão levando a um aumento na densidade tanto total como de células vivas, principalmente em resposta a um aumento na matéria orgânica lábil na superfície do sedimento. Outros fatores que podem ter influenciado a comunidade microbiana do sedimento são a possível diminuição da competição e predação devido ao evento de ressuspensão, além da maior oxigenação da coluna sedimentar. Esses fatores foram também provavelmente responsáveis pelo aumento na diversidade bacteriana após o evento de ressuspensão. A redistribuição das comunidades bacteriana na coluna sedimentar após o evento de ressuspensão foi observada levando a diferenças iniciais entre tratamento e controle. Porém, com o tempo as comunidades voltaram a ser semelhantes e maiores mudanças na comunidade bacteriana foram devido ao tempo de experimento e não ao tratamento. Membros dos grupos Gammaproteobacteria e Deltaproteobacteria foram os mais abundantes dentre as 
bandas seqüenciadas, o que é comumente encontrado entre as comunidades de sedimentos costeiros. 


\section{Capítulo 5: Influência da ressuspensão na distribuição vertical dos micro-organismos de sedimentos marinhos}

\subsection{Introdução}

Os micro-organismos são responsáveis por importantes transformações bioquímicas no sedimento marinho, incluindo principalmente a mineralização da matéria orgânica. Adicionalmente, os sedimentos provavelmente representam um dos mais complexos nichos microbianos da Terra, onde uma única grama de sedimento pode conter centenas de espécies bacterianas (Torsvik et al., 1990). Um dos mais importantes passos no estudo da comunidade microbiana no ambiente marinho é entender como as propriedades físicas e químicas do sedimento afetam a estrutura da comunidade como um todo. Entretanto, muitos estudos com micro-organismos de sedimentos marinhos têm sido focados em grupos funcionais específicos, porque os processos que eles catalisam podem ser medidos diretamente (e.g. Sahm et al., 1999; Jiang et al., 2009; Leloup et al., 2009).

Em geral, os gradientes físicos e químicos relacionados à profundidade providenciam nichos específicos para uma variedade de micro-organismos metabolicamente diversos nos sedimentos marinhos (Urakawa et al., 2000). Vários estudos vêm sendo conduzidos para determinar o elo entre a estrutura da comunidade bacteriana com os parâmetros ambientais do hábitat bêntico. Padrões relacionados à profundidade foram detectados para uma variedade de habitats bênticos, tais como exsudações frias (Inagaki et al., 2002), recifes de corais (Hewson \& Fuhrman, 2006), plataformas continentais (Bowman \& McCuaig, 2003; Franco et al., 2007), mar profundo (Luna et al., 2004) e regiões costeiras (Molari et al., 2012; Sun et al., 2012). Porém, nenhum estudo foi observado na região costeira tropical do Atlântico sul.

Vários fatores são conhecidos por influenciar a distribuição vertical dos microorganismos no sedimento. Processos hidrodinâmicos, por exemplo, são responsáveis por importantes modificações na estrutura física e química da coluna sedimentar (Hewson \& Fuhrman, 2006), sendo consequentemente, importantes para a estrutura da comunidade bacteriana do sedimento. Apesar de vários estudos terem sido feitos para observar o efeito da ressuspensão no ambiente marinho, a grande parte está relacionada com o processo na degradação da matéria orgânica e sua influência no acoplamento 
bento-pelágico, concentrando-se nos fluxos de nutrientes e partículas através da interface sedimento-água (Christiansen et al., 1997; Garstecki \& Wickhan, 2001; Tenberg et al., 2003; Ståhlberg et al., 2006; Almroth et al., 2009).

Apesar de alguns estudos terem relacionado diferenças na distribuição vertical da comunidade bacteriana aos padrões hidrodinâmicos do ambiente (Urakawa et al., 2000; Franco et al., 2007; Böer et al., 2009), nenhum estudo anterior ao presente mostrou a influência exclusiva do processo de ressuspensão na estrutura da comunidade bacteriana do sedimento, e principalmente na sua distribuição vertical na coluna sedimentar. Dessa forma, o principal objetivo do presente estudo foi avaliar como o processo de ressuspensão moderada, que ocorre naturalmente em regiões costeiras, influencia a distribuição vertical dos micro-organismos na coluna sedimentar. Para tanto foram realizados experimentos laboratoriais onde um evento de ressuspensão foi simulado em testemunhos coletados de uma região costeira da região de Ubatuba, São Paulo.

A região de Ubatuba apresenta uma grande incidência de frentes frias entre os meses de outono/inverno, e a ressuspensão é conhecidamente um processo importante para o incremento da produção primária na região (Gaeta et al., 1999). Dessa forma, esse processo deve também ser importante para a estruturação da comunidade bacteriana do sedimento, e para importantes modificações nos padrões de decomposição da matéria orgânica nesse ambiente.

\subsection{Material e Métodos}

\subsection{1. Área de estudo}

Na região sul e sudeste do Brasil a passagem de frentes frias é um evento comum que ocorre durante o ano todo. Porém, durante os meses de outono e inverno essas frentes frias aumentam em intensidade e frequência (Centro de Previsão do Tempo e Estudos Climáticos-CPTEC e Instituto Nacional de Pesquisas Espaciais-INPE). O ponto escolhido localiza-se na Plataforma Continental Sudeste Brasileira - PCSE, na costa de Ubatuba, litoral norte do Estado de São Paulo, com profundidade em torno de $35 \mathrm{~m}$, onde foi previamente obsevado um alto grau de ressuspensão sedimentar após passagens de frentes frias na região. No outono-inverno, os ventos de quadrante sul (atribuídos às frentes frias) levam ao esfriamento das águas superficiais e a intensificação de misturas devido aos ventos fortes (Castro-Filho et al., 1987). O 
aumento de frentes frias e homogeneidade da coluna de água durante esta época do ano tornam a ressuspensão e regeneração de nutrientes os principais fatores dirigindo a produtividade primária na região (Sassi \& Kutner, 1982).

\subsubsection{Amostragem e montagem experimental}

As amostras foram coletadas na região de Ubatuba, costa norte do estado de São Paulo, na plataforma sudeste brasileira, em uma área de transição entre águas costeiras e de plataforma $\left(23^{\circ} 34,480^{\prime} \mathrm{S}-45^{\circ} 00,271^{\prime} \mathrm{W}\right.$ e $35 \mathrm{~m}$ de profundidade). Os testemunhos foram coletados com um mini-multicorer e fatiado a bordo em quatro profundidades ( 0 2, 2-5, 5-10, 10-20 cm), homogeneizados e peneirados em peneira de $1 \mathrm{~mm}$. Um total de 39 testemunhos $(10 \mathrm{~cm}$ de diâmetro) foi preenchido com o sedimento peneirado, até $20 \mathrm{~cm}$ de coluna sedimentar, respeitando-se as profundidades. Os testemunhos foram mantidos em sistemas separados (um tratamento e um controle) sem luz, com oxigenação e circulação em uma sala com temperatura controlada $\left(19^{\circ} \mathrm{C}\right)$.

Após cinco dias de aclimatação, três testemunhos foram tomados para as análises iniciais $(\mathrm{t}=0)$. A ressuspensão foi simulada em 18 testemunhos através de bombas submersas $(280 \mathrm{~L} / \mathrm{h})$ colocadas a uma distância aproximada de $15 \mathrm{~cm}$ acima da coluna sedimentar por $12 \mathrm{~h}$ ininterruptas. Amostragens foram realizadas seis vezes no período total de 30 dias após o período de ressuspensão (t= 24 h, 48 h, 120 h, 240 h, 480 h, 720 h após a adição). Após um período de incubação para coleta de água para análises de fluxos sedimento-água o sedimento foi fatiado em 10 camadas de profundidade $(0-1,1-2,2-3,3-4,4-5,5-8,8-11,11-14,14-17,17-20 \mathrm{~cm})$ e amostrado para as diversas análises sedimentares.

\subsubsection{Características sedimentares}

As amostras de todas as camadas sedimentares foram analisadas quanto a clorofila a, feopigmentos e matéria orgânica total. A matéria orgânica total (MOT) foi obtida através do método de calcinação em forno mufla $\left(550^{\circ} \mathrm{C}\right)$ for 2,5-3h (Byers et al., 1978). Fitopigmentos foram extraídos com acetona $100 \%$ for $24 \mathrm{~h}$ a $-10^{\circ} \mathrm{C}$ e a absorbância foi medida (665 e 750nm) antes e após acidificação com 0,1 N HCl através de um espectrofotômetro (Plante-Cuny, 1978). As concentrações de clorofila-a e feopigmentos foram calculadas aplicando-se a fórmula sugerida por Lorenzen (1967). 


\subsubsection{Comunidade microbiana}

Para as análises da comunidade microbiana três camadas sedimentares foram selecionadas, além da superficial, a camada subsuperficial $(1-2 \mathrm{~cm})$, uma camada intermediária (4-5 cm), e uma camada profunda $(14-17 \mathrm{~cm})$.

De cada réplica de sedimento amostrada, $1 \mathrm{ml}$ de sedimento foi retirado com seringa estéril e alocado em potes de plástico com $9 \mathrm{ml}$ de formol salino $2 \%$ pré-filtrado em filtro $0,2 \mu \mathrm{m}$. A densidade de procariotos foi determinada através de método de contagem direta em microscópio de epifluorescência, usando um kit de viabilidade Live/Dead (L/D) BacLight (L-7012, Molecular Probes, Eugene, OR; Quéric et al., 2004). As amostras foram diluídas 10.000 vezes após um período de agitação de 15 min. Dois mililitros das amostras diluídas foram coradas com $3 \mu \mathrm{l}$ de 1:1 dos corantes (6.68 M SYTO 9 e 20 M iodeto propídico) e incubadas por $30 \mathrm{~min}$. em temperatura ambiente. A amostra foi filtrada em filtro policarbonato black de $0,2 \mu \mathrm{m}$ e montada em lâmina. Um total de 400 células por amostra foi contado em microscópio de epifluorescência.

A extração de DNA das amostras de sedimento foi realizada utilizando o PowerSoil DNA Isolation Kit (MoBio Laboratoires, CA, USA) de acordo com as especificações do fabricante. O DNA extraído foi quantificado e sua pureza checada através de medidas de absorbância com espectrofotômetro.

A região variável V3 do gene $16 \mathrm{~S}$ do rRNA foi amplificada do DNA extraído usando os primers 338f-GC e 518r para bactéria. A mistura para as reações de PCR em um total de $50 \mu \mathrm{l}$ consistiu de: $2 \mu \mathrm{l}$ de DNA extraído (aproximadamente $20 \mathrm{ng}$ ), $5 \mu \mathrm{l}$ 10X PCR Buffer (Invitrogen), 1,5 $\mu \mathrm{l} \mathrm{MgCl}_{2}$ (50mM), 0,4 $\mu \mathrm{l} \mathrm{dNTP}(100 \mathrm{mM}), 1 \mathrm{U}$ Taq polymerase (Platinum, Invitrogen), água livre de ácido nucléico até completar o volume. O PCR foi realizado através de um termociclador (Eppendorf Mastercycler Personal), nas seguintes condições: $94^{\circ} \mathrm{C}$ por $5 \mathrm{~min}$. seguido por 30 ciclos de $94^{\circ} \mathrm{C}$ por $1 \mathrm{~min}$., $55^{\circ} \mathrm{C}$ por $1 \mathrm{~min}$., e $72^{\circ} \mathrm{C}$ por $2 \mathrm{~min}$., com uma extensão do passo final a $72^{\circ} \mathrm{C}$ por 10 min. Todos os produtos finais de PCR foram checados e quantificados por eletroforese em gel de agarose $1 \%(\mathrm{w} / \mathrm{v})$.

As análises de DGGE foram divididas entre as camadas sedimentares, e para observar a influência da ressuspensão na distribuição vertical, um DGGE adicional foi realizado com as amostras inicial e tratamentos após 24 h, 48 h e 120 h da ressuspensão e amostra do controle $120 \mathrm{~h}$. Na análise de DGGE, foi utilizado um gel de 
poliacrilamida a $8 \%$, com uma gradiente de denaturação de 30-70\% (100\% denaturante 7M ureia, e $40 \%$ formamida). Concentrações similares de produto de PCR foram colocadas no gel e a eletroforese foi realizada em tampão TAE $1 \mathrm{X}$ por $16 \mathrm{~h}$ a uma constante de $60 \mathrm{~V}$ a $60{ }^{\circ} \mathrm{C}$, utilizando o sistema Dcode Universal Mutation Detection System (Bio-Rad Laboratories, Richmond Calif.). O gel foi corado com nitrato de prata modificado de Sanguinetti et al. (1994) e a imagem obtida com o auxílio de um escâner.

\subsubsection{Análises estatísticas}

As relações entre a distribuição vertical das variáveis sedimentares medidas foram testadas através do teste de correlação de Pearson $(n=95)$. Foi realizada uma Análise de Redundância Canônica (RDA; Canoco 4.5; Ter Braak \& Smilauer, 2002) para avaliar a influência dos fatores abióticos na abundância de procariotos. O DGGE foi analisado através do programa BioNumerics 6.1 (AppliedMaths). Os dendogramas foram construídos através do coeficiente de similaridade de Dice e pela análise de agrupamento pelo método da distância média não ponderada (UPGMA). Com o objetivo de estabelecer qual variável melhor explicou o perfil de bandas do DGGE, Análises de Correspondência Canônica (CCA, CANOCO 4.5) foram realizadas. A fim de observar a importância do efeito da ressuspensão nos resultados da comunidade microbiana, este foi adicionado aos fatores abióticos para as análises multivariadas.

\subsection{Resultados}

\subsubsection{Variáveis abióticas}

Os valores de clorofila-a medidos na coluna sedimentar foram diferentes entre o tratamento e o controle (Figura 5.1). Após a ressuspensão, os valores de clorofila-a aumentaram na camada superficial do sedimento, diminuindo com a profundidade até $120 \mathrm{~h}$ após o evento. Após $240 \mathrm{~h}$ da resssuspensão, os valores de clorofila-a distribuíram-se mais homogeneamente pela coluna sedimentar, não mostrando grandes variações com a profundidade. As análises mostraram maiores valores de clorofila-a nas camadas intermediárias do sedimento após 480 h da ressuspensão, enquanto após 720 h houve uma grande variação na distribuição da clorofila-a na coluna sedimentar (Figura 5.1). O controle apresentou menor variação temporal na distribuição da clorofila-a na coluna sedimentar (Figura 5.1). De um modo geral, maiores valores de clorofila-a foram 
encontrados nas camadas superficiais do sedimento, diminuindo com a profundidade. Porém, picos subsuperficiais de clorofila-a foram observados nos tempos de 24 h e $48 \mathrm{~h}$ após o início do experimento (Figura 5.1).

As distribuições verticais de feopigmentos foram semelhantes entre o controle e tratamento, não havendo grandes variações temporais em ambos (Figura 5.2). De um modo geral, os valores de feopigmentos foram maiores na camada superficial diminuindo com a profundidade até aproximadamente $5 \mathrm{~cm}$, voltando a aumentar e mantendo-se constante com a profundidade (Figura 5.2).

A matéria orgânica total foi mais abundante nas camadas mais profundas do sedimento (Figura 5.3). No controle houve uma diminuição da matéria orgânica com a profundidade até $5 \mathrm{~cm}$, seguido por um aumento com a profundidade na maioria dos períodos amostrados (Figura 5.3). Já as amostras nas quais a ressuspensão foi realizada, a matéria orgânica teve maior variação no sedimento, apresentando picos subsuperficiais após 48 h, 120 h e 480 h de experimento (Figura 5.3).
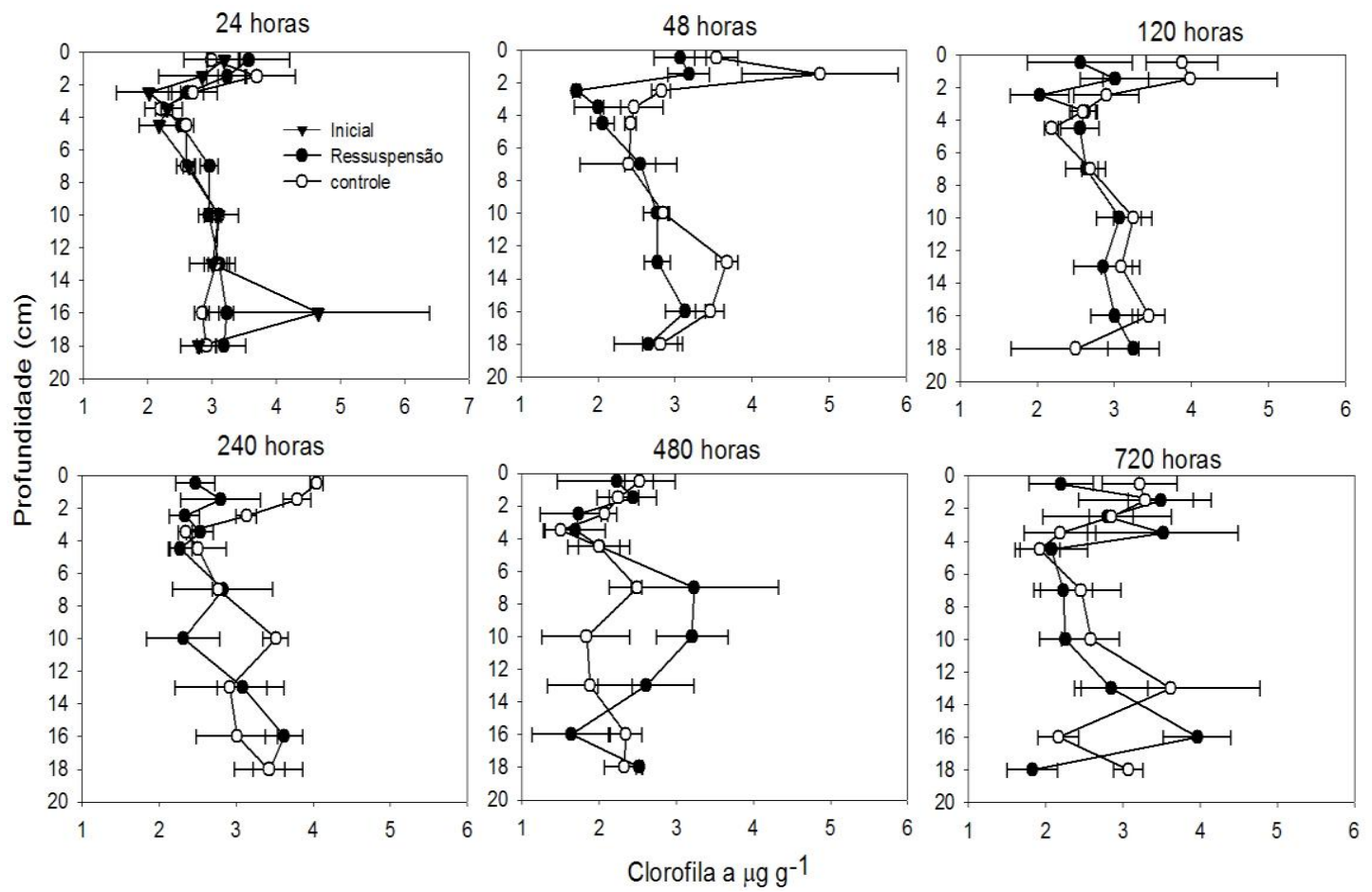

Figura 5.1: Perfis de clorofila-a $\left(\mu \mathrm{g} \mathrm{g}^{-1}\right)$ dos primeiros $20 \mathrm{~cm}$ do sedimento, média \pm erro-padrão, durante os períodos amostrados. 

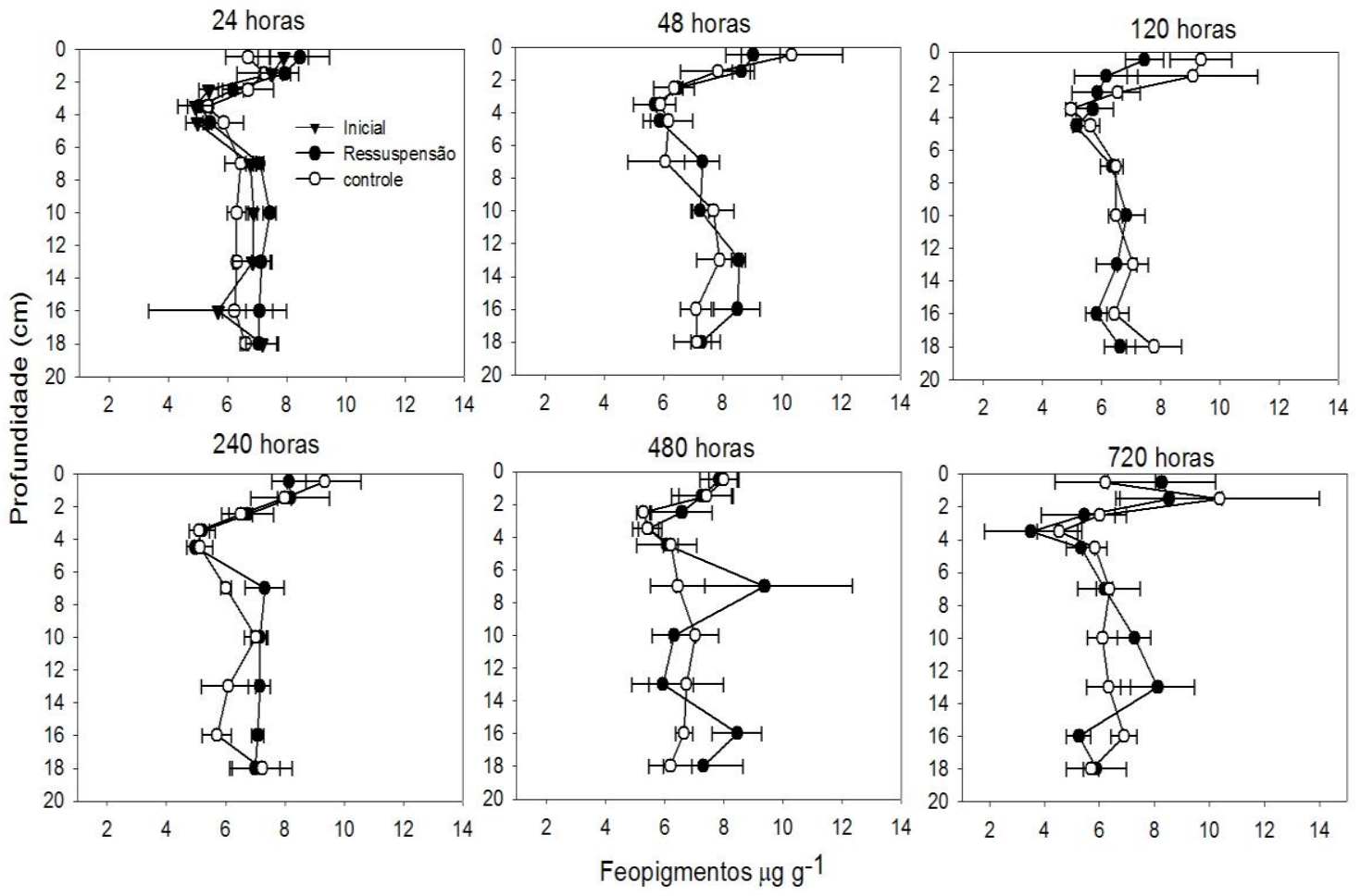

Figura 5.2: Perfis de feopigmentos ( $\mu \mathrm{g} \mathrm{g}^{-1}$ sedimento seco) dos primeiros $20 \mathrm{~cm}$ do sedimento, média \pm erro-padrão, durante os períodos amostrados.
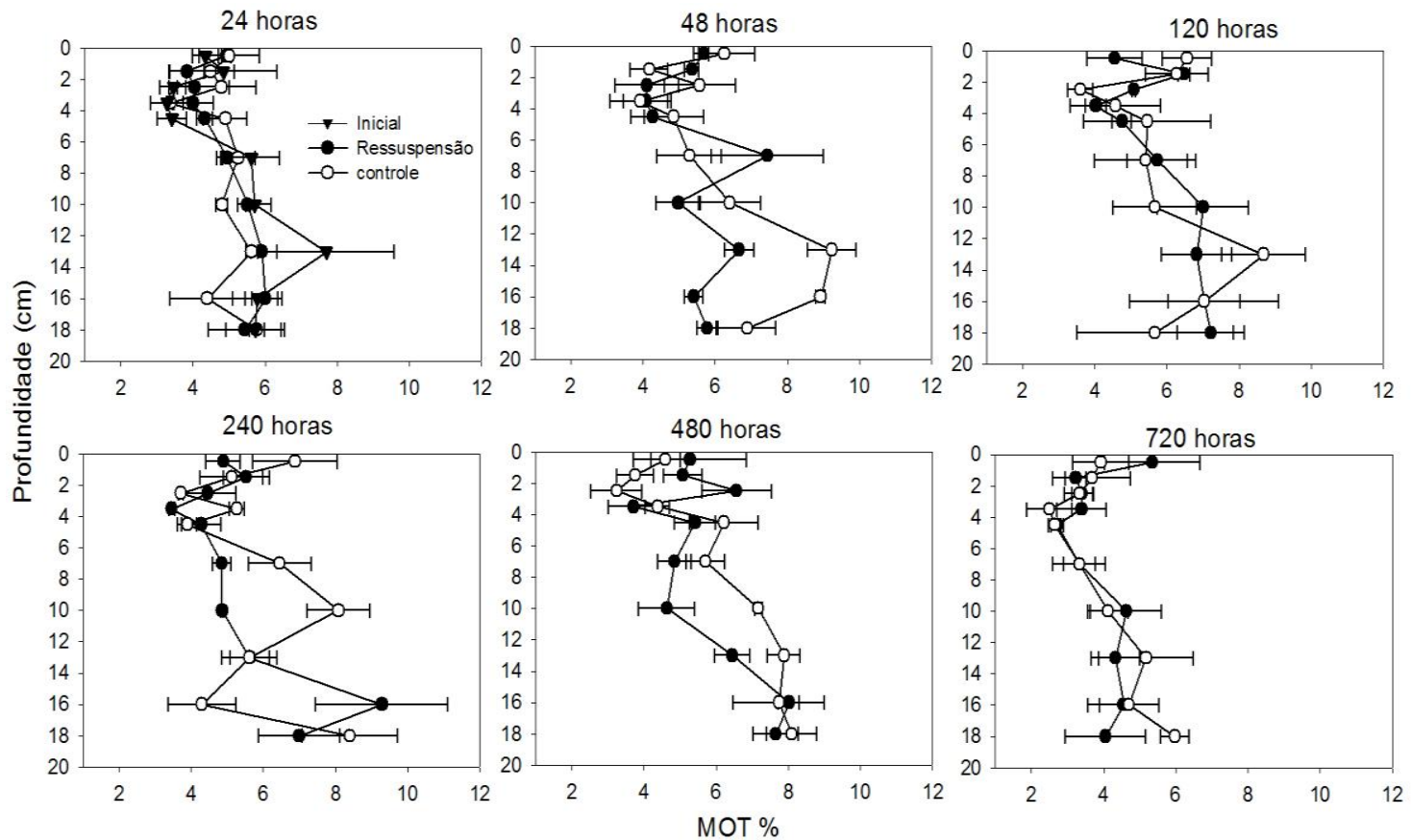

Figura 5.3: Perfis de matéria orgânica total (MOT \%) dos primeiros $20 \mathrm{~cm}$ do sedimento, média \pm erro-padrão, durante os períodos amostrados. 


\subsubsection{Densidade de procariotos}

A distribuição dos procariotos na coluna sedimentar variou tanto entre tratamento e controle quanto temporalmente (Figura 5.4). Maiores densidades de procariotos foram encontradas nas camadas mais profundas do sedimento na maioria dos tempos amostrados no controle. Apenas após 240 h de experimento maiores valores foram observados nas camadas superficiais (Figura 5.4). Já nos testemunhos onde a ressuspensão foi aplicada, foram observadas maiores densidades procarióticas nas camadas superficiais em praticamente todos os tempos amostrados (Figura 5.4). A camada subsuperficial apresentou os maiores valores de densidade total nos tempos 24 h, 48 h, 240 h e 480 h após o evento de ressuspensão, enquanto os tempos restantes apresentaram maiores valores na camada superficial (Figura 5.4).

A densidade de procariotos vivos seguiu praticamente o mesmo padrão encontrado para a densidade total (Figura 5.5). Maiores valores de densidade de procariotos vivos foram encontrados nas camadas intermediárias e profundas do sedimento no controle nos tempos até 240 h após o início do experimento, enquanto maiores valores na camada superficial e subsuperficial foram observados nos testemunhos onde a ressuspensão foi aplicada (Figura 5.5).
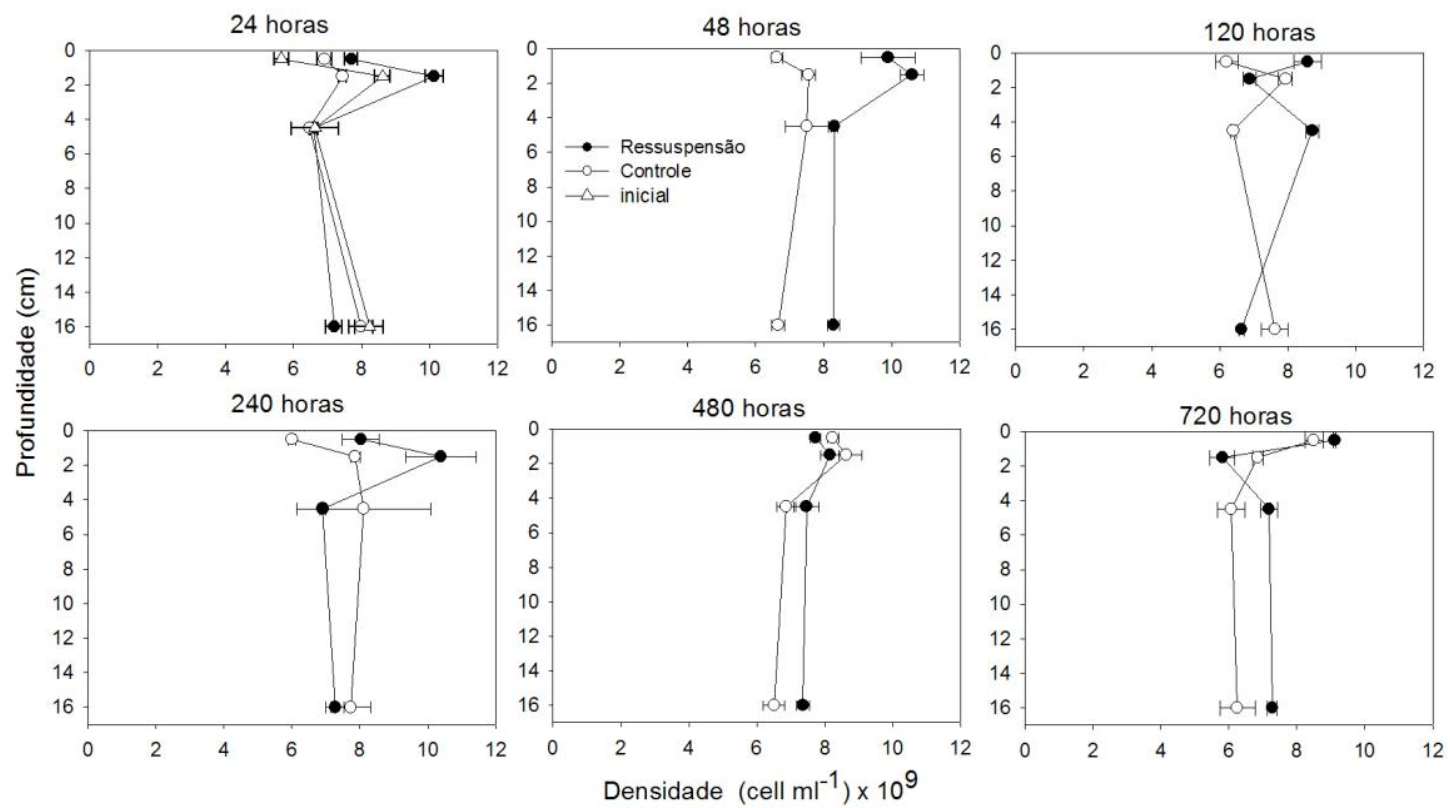

Figura 5.4: Perfis de densidade total de procariotos (células $\mathrm{ml}^{-1}$ ) em quatro camadas da coluna sedimentar $(0-1,1-2,4-5$ e 14-17 cm), média \pm erro padrão, nos tempos amostrados. 

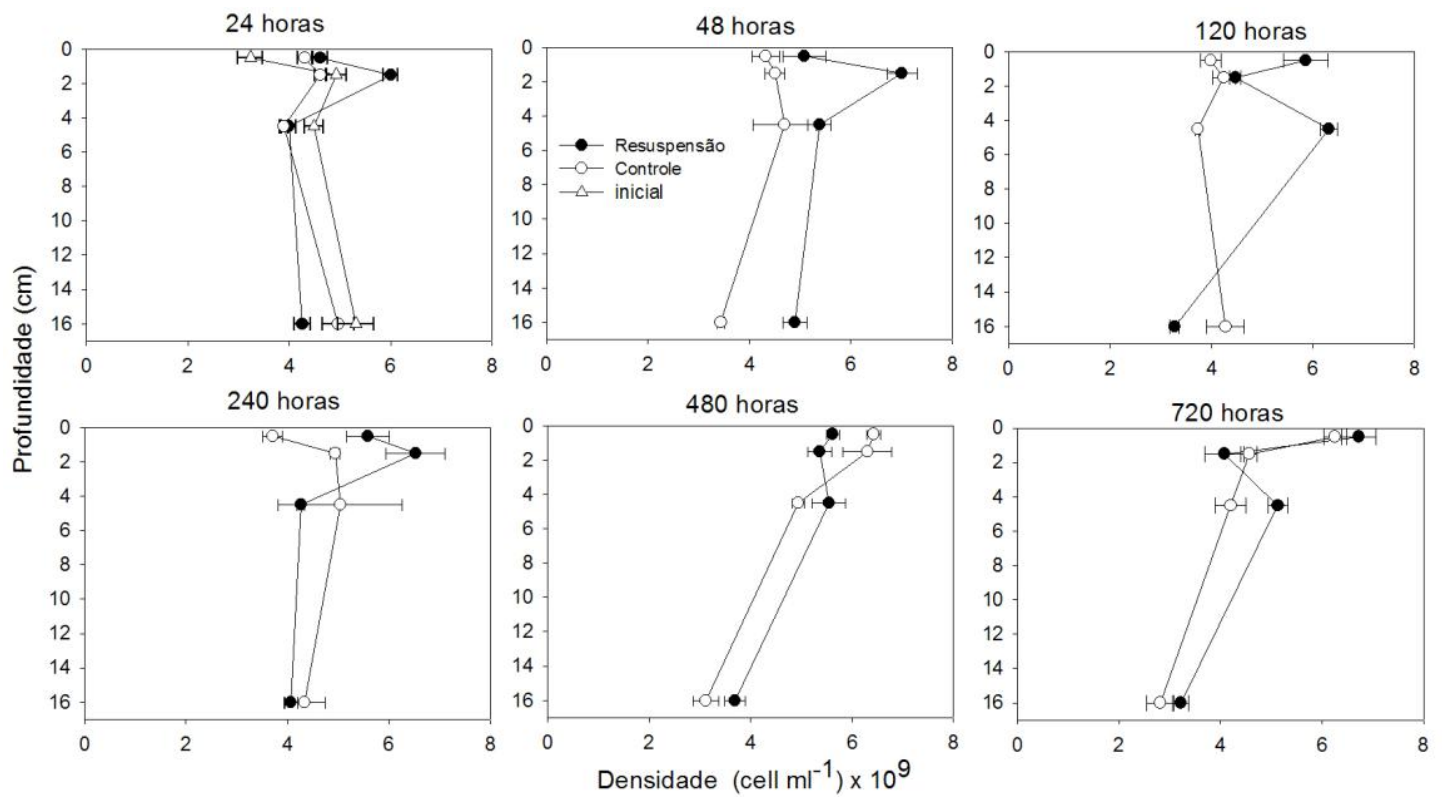

Figura 5.5: Perfis de densidade de procariotos vivos (células $\mathrm{ml}^{-1}$ ) em quatro camadas da coluna sedimentar (0-1, 1-2, 4-5 e 14-17 cm), média \pm erro padrão, nos tempos amostrados.

A análise de correlação de Pearson mostrou uma correlação negativa entre os valores de MOT e densidade de procariotos vivos $(\mathrm{r}=-0.387, \mathrm{p}=0.022)$. A RDA mostrou que apenas o evento da ressuspensão foi significativamente importante para a distribuição da densidade de procariotos na coluna sedimentar (Figura 5.6). A análise explicou apenas $20.1 \%$ da variação dos dados, sendo que o evento de ressuspensão foi responsável por $15 \%$ da variação observada. A análise separou principalmente as amostras do controle das amostras onde a ressuspensão foi realizada (Figura 5.6). 


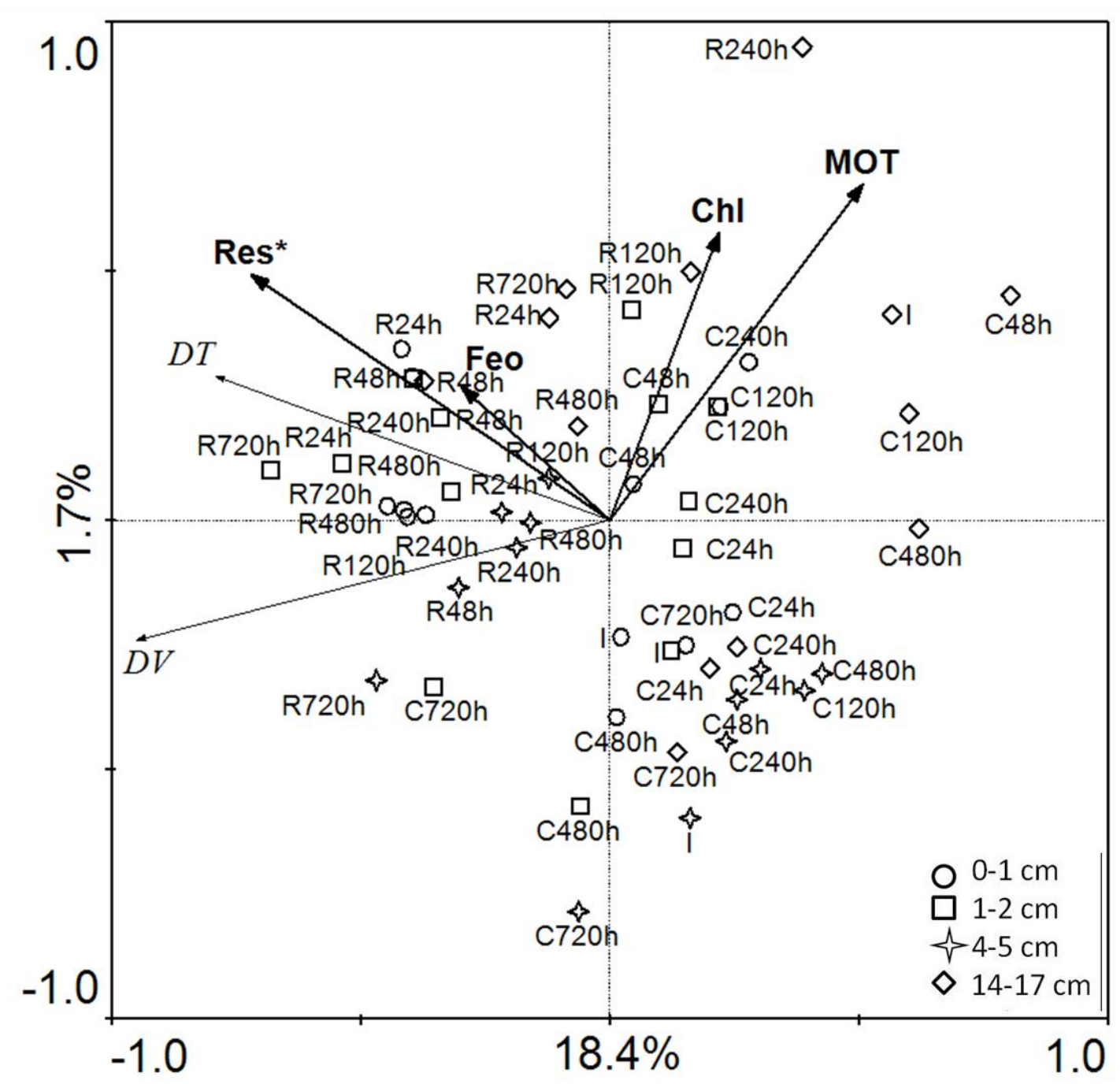

Figura 5.6: Análise de redundância (RDA) observando a influência das variáveis abióticas ( $\mathrm{n}=95,4$ variáveis) na densidade de procariotos $(\mathrm{n}=95,2$ variáveis). * variável com influência significativa segundo teste de Monte Carlo (9999 permutações). Res. Ressuspensão, Chl. Clorofila-a, Feo. Feopigmentos, DT. Densidade total de procariotos, DV. Densidade de procariotos vivos, C. controle, R. tratamento com ressuspensão.

\subsubsection{DGGE e diversidade bacteriana}

A estrutura da comunidade de bactérias do sedimento foi comparada com base na análise de DGGE do gene $16 \mathrm{~S}$ do rRNA. Para observar as mudanças, foram realizadas quatro DGGE onde foi observada a influência do tratamento nas comunidades de cada camada sedimentar e um último, onde algumas amostras foram escolhidas para observar a diferenciação entre as camadas do sedimento. A análise de DGGE mostrou um grande número de bandas, principalmente na camada intermediária do sedimento $(4-5 \mathrm{~cm})$ (Figura 5.7). Na camada subsuperficial $(1-2 \mathrm{~cm})$, o número de bandas não apresentou grandes variações após a ressuspensão, mostrando maior número 
de bandas 120 h após o tratamento e menor 240 h (Figura 5.7). Já o controle apresentou uma variação maior no número de bandas com o tempo de experimento, apresentando os maiores valores após 120 e 240 h de experimento (Figura 5.7). Houve um aumento no número de bandas com o tempo na camada intermediária $(4-5 \mathrm{~cm})$, tanto após o evento de ressuspensão quanto no controle. Na camada profunda $(14-17 \mathrm{~cm})$, o número de bandas aumentou logo após a ressuspensão e depois diminuiu com o tempo, enquanto no controle o número de bandas aumentou após 48 h de experimento e voltou a diminuir gradativamente com o tempo de experimento (Figura 5.7). O DGGE referente à distribuição vertical mostrou o mesmo padrão encontrado nos feitos separadamente, os maiores números de bandas foram encontrados na camada superficial e intermediária em todas as amostras (Figura 5.7).
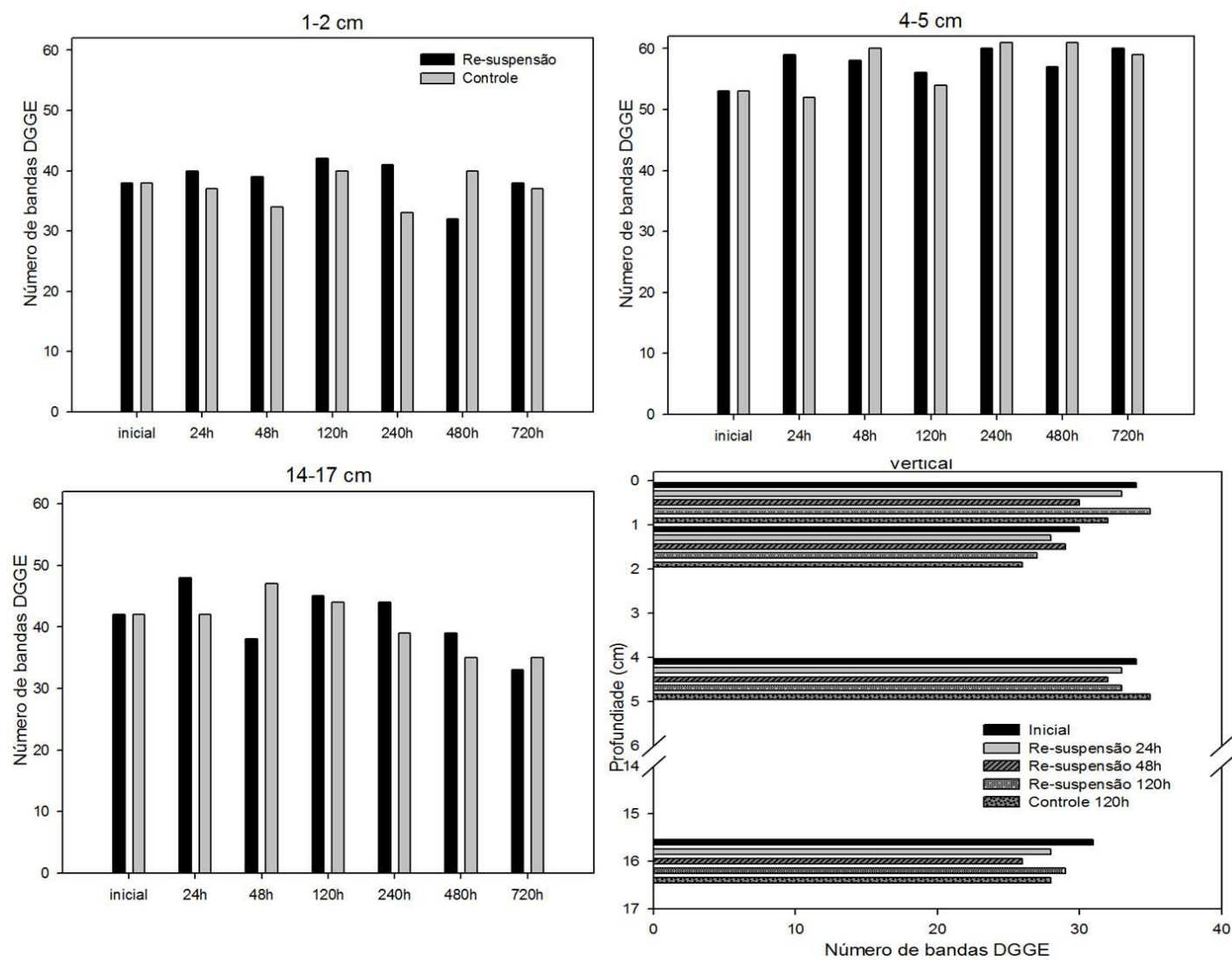

Figura 5.7: Número de bandas identificadas no gel de DGGE da comunidade bacteriana nos estratos do sedimento.

A comunidade bacteriana do sedimento mostrou um grau de similaridade variado entre as amostras nas camadas estudadas. O cluster realizado a partir do padrão de bandas encontradas nas análises de DGGE mostrou mais de 62\% de similaridade entre as amostras na camada subsuperficial (1-2 cm; Figura 5.8), mais de $83 \%$ de 
similaridade na camada intermediária $(4-5 \mathrm{~cm}$; Figura 5.9) e mais de $76 \%$ na camada profunda do sedimento (14-17 cm; Figura 5.10). Na camada subsuperficial, foram formados três grandes grupos com mais de $76 \%$ de similaridade, separando as amostras principalmente quanto ao tempo de amostragem (Figura 5.8). A camada intermediária mostrou um alto grau de semelhança entre os padrões de bandas, mostrando uma separação em quatro grandes grupos com mais de $89 \%$ de similaridade, mais uma vez sendo o tempo de amostragem mais importante para a mudança na comunidade do que o tratamento (Figura 5.9). Na camada profunda do sedimento foi observada a separação das amostras em três grandes grupos com mais de $80 \%$ de similaridade. Nessa camada, a ressuspensão foi a que mais influenciou na mudança da comunidade, principalmente nos primeiros tempos de amostragem (Figura 5.10).

Para observar mudanças na distribuição vertical das bactérias, um DGGE foi feito com as amostras inicial, ressuspensão 24 h, 48 h e 120 h, e controle 120 h, nos estratos estudados (Figura 5.11). O agrupamento realizado com o padrão de bandas encontrado mostrou uma similaridade de mais de $73 \%$ entre as amostras, formando três grandes grupos com mais de $75 \%$ de semelhança. O primeiro grupo foi formado pelas amostras inicial 0-1 e controle 4-5 e 14-17 cm. O segundo agrupou as amostras inicial e ressuspensão $24 \mathrm{~h}$ da camada $14-17 \mathrm{~cm}$. O terceiro grupo foi formado pelas amostras

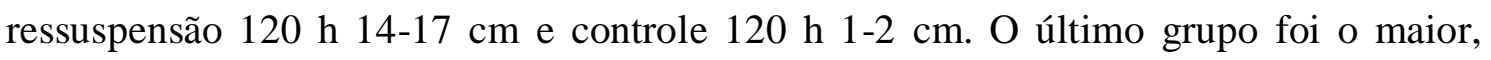
sendo formado pelo restante das amostras (Figura 5.11).

As CCA foram realizadas com o padrão de bandas encontradas para cada DGGE e com as variáveis sedimentares medidas onde o tratamento de ressuspensão foi considerado (Figura 5.12). Na camada subsuperficial, a CCA explicou apenas 33,2\% da variação dos dados, não apresentando influência significativa de nenhuma variável medida no padrão de variação da comunidade bacteriana, separando as amostras principalmente quanto ao tempo de amostragem (Figura 5.12a). Na camada intermediária mais uma vez nenhuma variável ambiental medida influenciou significativamente a distribuição das bandas encontradas e a CCA explicou somente $21,5 \%$ da variação dos dados, separando as amostras principalmente quanto ao tempo de amostragem (Figura 5.12b). A CCA realizada com as amostras da camada profunda explicou $26,6 \%$ da variação dos dados, mostrando uma influência significativa da clorofila-a na variação da comunidade bacteriana e levando a maiores diferenciações entre as amostras do tratamento e controle (Figura 5.12c). Já na análise referente à distribuição vertical, a CCA explicou apenas $21,9 \%$ da variação dos dados nos dois 
primeiros eixos e separou as amostras principalmente em relação tratamento de ressuspensão. Nessa análise a ressuspensão foi a única variável que influenciou significativamente o padrão de bandas encontrado nas amostras (Figura 5.12d).
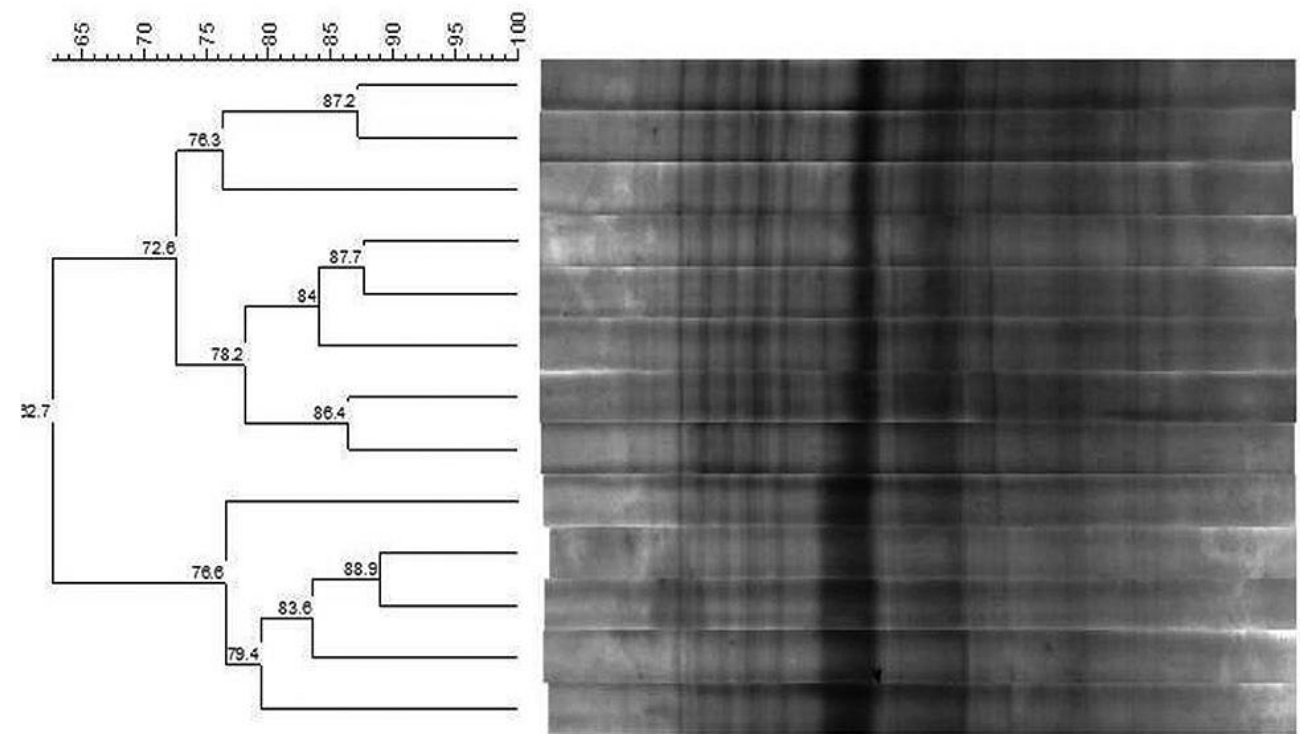

Inicial

$\mathrm{R} 24 \mathrm{~h}$

$\mathrm{C} 24 \mathrm{~h}$

$\mathrm{C} 48 \mathrm{~h}$

R48h

R120h

C120h

R240h

$\mathrm{C} 240 \mathrm{~h}$

$\mathrm{C} 480 \mathrm{~h}$

R480h

R720h

$\mathrm{C} 720 \mathrm{~h}$

Figura 5.8: Análise de agrupamento do padrão de bandas de DGGE das bactérias sedimentares da camada 1-2 $\mathrm{cm}$ usando a análise UPGMA. Matriz de similaridade calculada usando DICE.

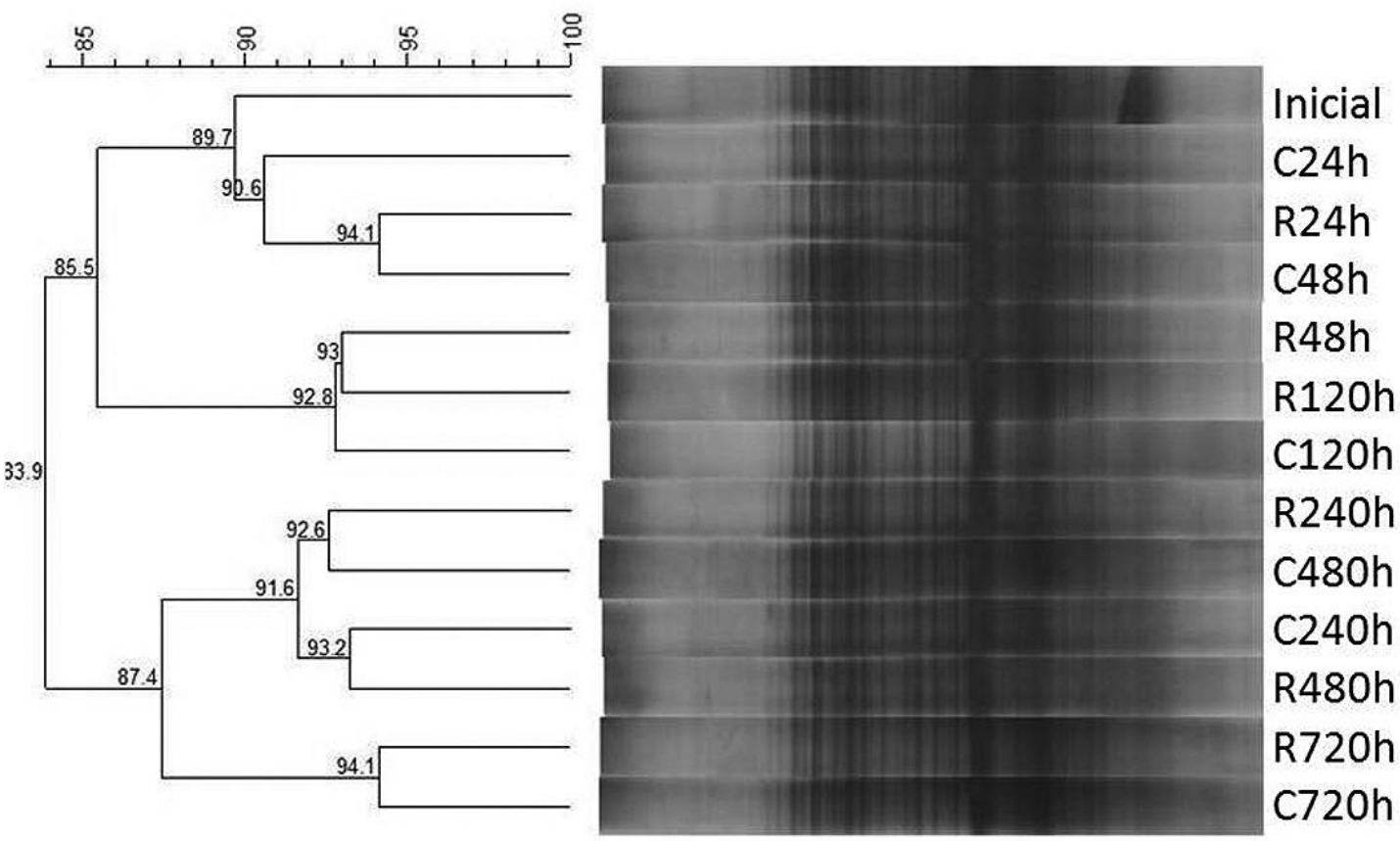

Figura 5.9: Análise de agrupamento do padrão de bandas de DGGE das bactérias sedimentares da camada 4-5 $\mathrm{cm}$ usando a análise UPGMA. Matriz de similaridade calculada usando DICE. 

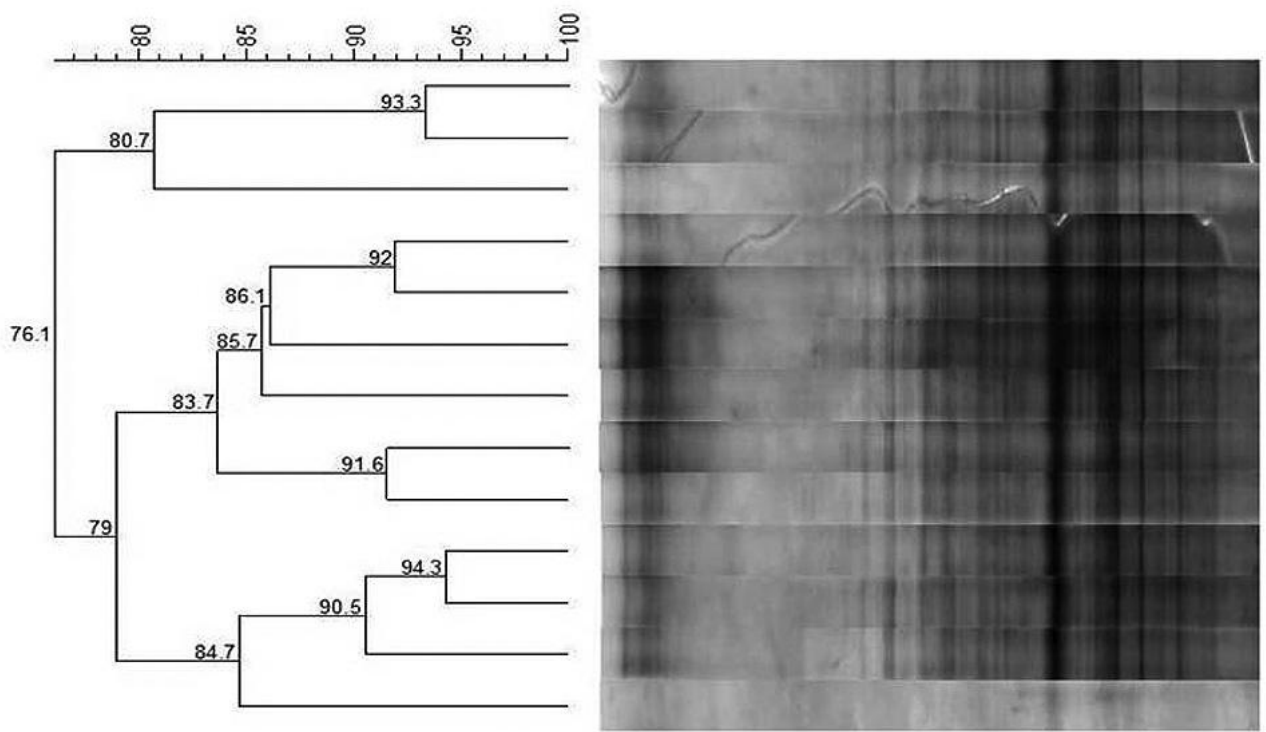

Inicial

R24h

R48h

$\mathrm{C} 24 \mathrm{~h}$

R120h

$\mathrm{C} 48 \mathrm{~h}$

C120h

R240h

C240h

$\mathrm{C} 480 \mathrm{~h}$

$\mathrm{C} 720 \mathrm{~h}$

$\mathrm{R} 480 \mathrm{~h}$

R720h

Figura 5.10: Análise de agrupamento do padrão de bandas de DGGE das bactérias sedimentares da camada 14-17 cm usando a análise UPGMA. Matriz de similaridade calculada usando DICE.
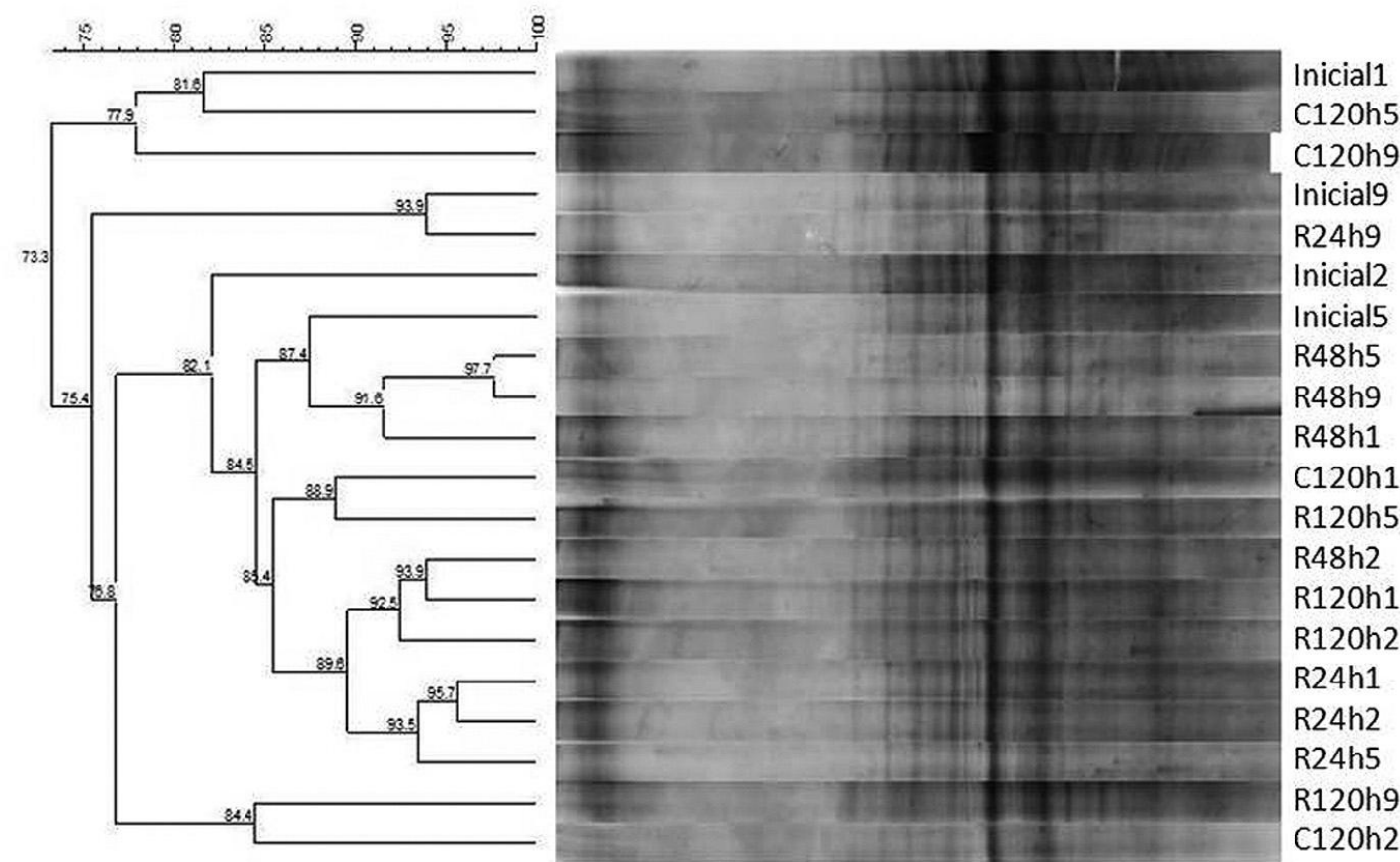

Figura 5.11: Análise de agrupamento da estrutura vertical do padrão de bandas de DGGE das bactérias sedimentares usando a análise UPGMA. Matriz de similaridade calculada usando DICE. 

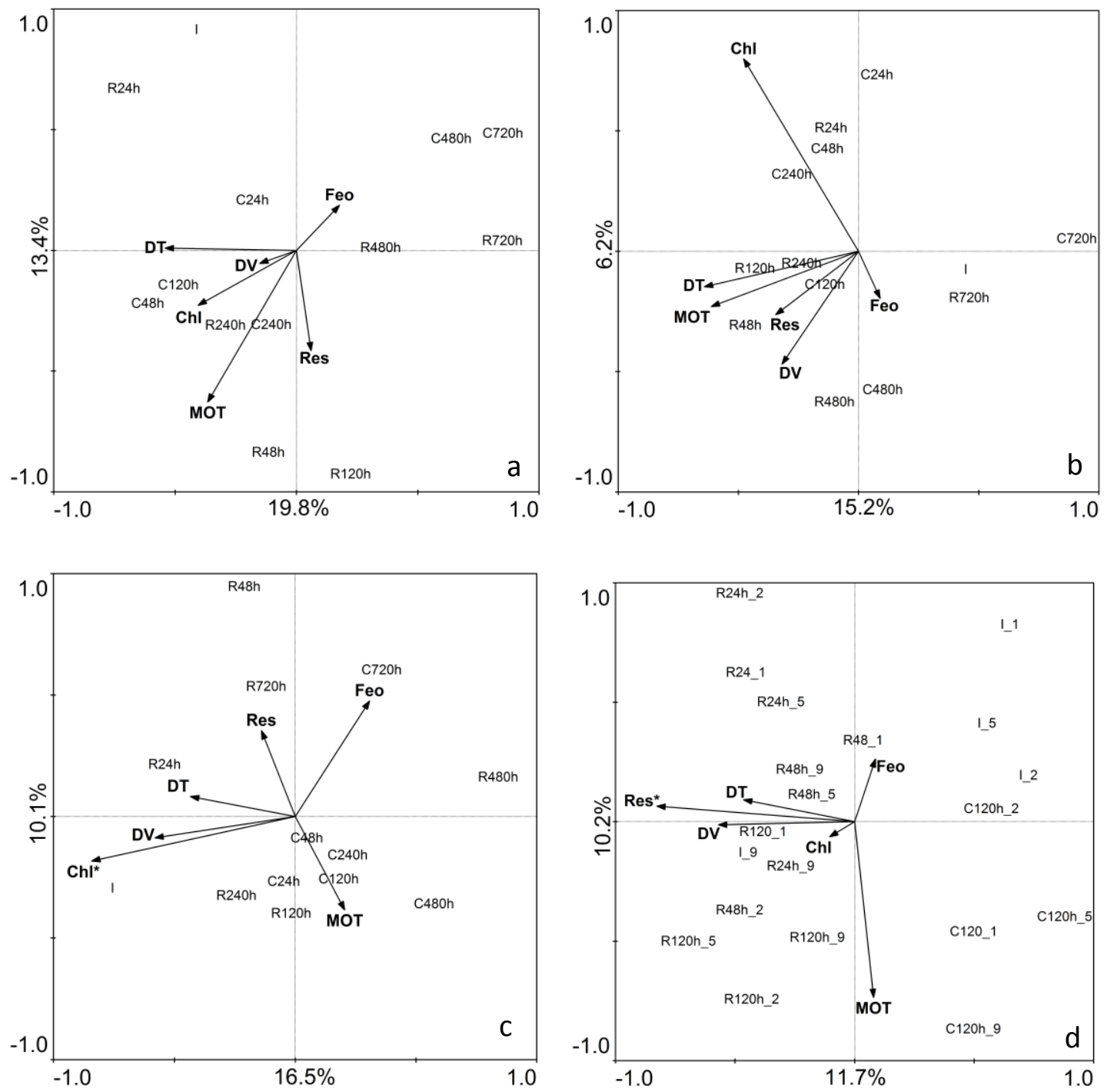

Figura 5.12: Análise de correspondência canônica (CCA) usando os perfis de PCR-DGGE das amostras do sedimento e as variáveis sedimentares medidas. a. 1-2 cm; b. 4-5 cm; c. 14-17 cm; d. distribuição verical. * variável com influência significativa na variação das bandas de DGGE, segundo teste de Monte Carlo (9999 permutações).

\subsection{Discussão}

\subsubsection{Variáveis abióticas}

Nas primeiras camadas do sedimento a matéria orgânica é decomposta rapidamente. A distribuição vertical da matéria orgânica é controlada principalmente por tais processos de degradação e mistura física das partículas sedimentares (Sun et al., 1994; Stoeck \& Kröncke, 2001). Geralmente, a labilidade da matéria orgânica diminui com a profundidade do sedimento, mesmo em sedimentos costeiros com bioturbação moderada (Kristensen, 1993). Nesses ambientes, ondas e correntes de fundo são também altamente atuantes e responsáveis pela redistribuição da matéria orgânica e 
compostos inorgânicos dissolvidos e particulados tanto verticalmente na coluna sedimentar quanto horizontalmente no assoalho marinho (Stoeck \& Kroncke, 2001; Tengberg et al., 2003; Almroth et al., 2009).

De uma forma geral, a ressuspensão do sedimento leva também à ressuspensão e redistribuição da matéria orgânica antes presente e preservada nas camadas mais profundas do sedimento. A matéria orgânica suspensa geralmente é composta por uma mistura de material fresco e mais refratário, que por apresentar taxas de decomposição mais lentas acaba sendo preservado em sedimentos mais profundos. Ao ser ressuspenso, este material é exposto a condições de decomposição mais favoráveis, sendo mais rapidamente decompostos (Kristensen \& Holmer, 2001; Ståhlberg et al., 2006) .

No presente estudo foi observado um aumento de clorofila-a na camada superficial e subsuperficial do sedimento após a ressuspensão, não observado no controle. Como a manutenção do experimento no escuro preveniu a produção primária, o evento de ressuspensão e consequente deposição da matéria orgânica foi o principal responsável por esse aumento. A ressuspensão é responsável também pelo aumento na oxigenação das primeiras camadas sedimentares, o que leva a um aumento nas taxas de decomposição desse material orgânico lábil (Kristensen, 2000; Kristensen \& Holmer, 2001; Polymenakou et al., 2005b). Com o tempo foi observado que maiores valores de clorofila-a passaram a ser encontrados nas camadas mais profundas, provavelmente devido a taxas de decomposição mais lentas nestes locais, levando a uma maior preservação da matéria orgânica (Canfield, 1994; Stoeck \& Kröncke, 2001). Devido a essas baixas taxas de decomposição, geralmente são encontradas altos valores de matéria orgânica nas camadas mais profundas do sedimento, como o observado no presente estudo.

\subsubsection{Comunidade microbiana}

Maiores valores de densidade de procariotos foram observados nos primeiros centímetros da camada sedimentar na maior parte das amostras, um padrão comumente encontrado em sedimentos marinhos, onde a densidade microbiana parece diminuir com o aumento da profundidade do sedimento (Parkes, et al., 2000; Eardly et al., 2001; Molari et al., 2012).

O fator crucial em controlar a distribuição dos procariotos em sedimentos marinhos é a quantidade e qualidade da matéria orgânica do sedimento. A importância 
do input da matéria orgânica é fortemente determinada pela disponibilidade para o ataque dos micro-organismos. Foi observado que o processo de ressuspensão foi responsável por um aumento de clorofila-a nas camadas superficiais do sedimento, o que foi acompanhado por um aumento na densidade de procariotos totais e vivos, apesar de correlações significativas não terem sido observadas entre as variáveis. As bactérias reagem rapidamente à mudança de substrato, porém essa relação entre substrato e micro-organismos pode ser frequentemente mascarada por influências das circunstâncias hidrodinâmicas como a ressuspensão do sedimento devido a correntes e ondas (Stefanija et al., 2009). Os testes mostraram que o evento de ressuspensão foi o mais significativo para as variações na densidade dos procariotos. Além de aumentar a disponibilidade de alimento, a ressuspensão é conhecidamente responsável por aumentar a oxigenação das camadas superficiais do sedimento aumentando suprimento de aceptores de elétrons dissolvidos, promovendo a retirada de metabólitos inibidores e um aumento na atividade e, consequentemente, na densidade dos procariotos nessas camadas do sedimento (Kristensen, 2000; Rusch et al., 2003; Wakeham \& Canuel, 2006; Franco et al., 2007).

Os resultados da análise de DGGE mostraram uma alta diversidade de bactérias no sedimento costeiro da região de Ubatuba. A alta diversidade em sedimentos marinhos tem sido previamente reportado tanto em regiões costeiras (Franco et al., 2007; Edlund et al., 2008; Molari et al., 2012) quanto em mar profundo (Urakawa et al., 2001; Luna et al., 2004).

É geralmente assumido que a disponibilidade de energia, variação de nichos e o número de recursos alimentares são maiores na superfície do assoalho marinho do que nas camadas mais profundas do sedimento, resultante da presença de protozoários e metazoários e da disponibilidade de uma variedade de recursos orgânicos diferentes (lábeis e refratários, e de várias origens diferentes) e aceptores de elétrons variados. Dessa forma dever-se-ia esperar que maiores números de bandas fossem encontrados nas camadas mais superficiais da coluna sedimentar. Entretanto, o número de bandas foi maior nas camadas intermediárias do sedimento $(4-5 \mathrm{~cm})$ quando comparadas com as superficiais e profundas. Um aumento no número de bandas com a profundidade foi previamente descrito por outros trabalhos em sedimentos marinhos com alto grau de hidrodinamismo (Urakawa et al., 2000; Franco et al., 2007; Böer et al., 2009), relacionando as maiores diversidades nas camadas mais profundas do sedimento geralmente a maiores estabilidades encontradas nesses locais. No entanto, no presente 
estudo, tanto o controle sem distúrbio, quanto o tratamento com ressuspensão apresentaram valores elevados de bandas nas camadas mais profundas, mostrando que a alta disponibiblidade de nutrientes inorgânicos e matéria orgânica lábil nas camadas superficiais do sedimento pode ter favorecido um rápido crescimento de generalistas tolerantes a oxigênio, enquanto as camadas profundas podem ter suportado uma comunidade microbiana mais heterogênea de táxons anaeróbicos de crescimento lento com capacidades metabólicas específicas. Adicionalmente, tanto a alta similaridade entre as amostras nas análises de agrupamento quanto a CCA mostrou que a comunidade bacteriana da camada intermediária foi a que apresentou as menores mudanças estruturais, confirmando uma maior estabilidade desta camada com relação aos padrões biogeoquímicos.

A ressuspensão levou a um aumento da diversidade em todas as camadas estudadas, e foi responsável por discreta mudança na estrutura da comunidade de cada camada e na sua distribuição vertical. Apesar disso, a estrutura da comunidade bacteriana foi relativamente constante dentro de cada camada, e apresentou maiores variações com o tempo do que devido ao tratamento. A camada subsuperficial foi a que apresentou a menor similaridade entre as amostras, e, apesar da análise de cluster não ter mostrado uma forte influência da ressuspensão, a CCA mostrou uma maior separação entre as amostras do tratamento e controle. De fato, a análise de DGGE mostrou que $8 \%$ das bandas observadas foram encontradas apenas nas amostras onde a ressuspensão foi aplicada. Adicionalmente, a ressuspensão foi o fator mais importante para as mudanças na distribuição vertical das comunidades bacterianas na coluna sedimentar.

É bem conhecido que os sedimentos são caracterizados por forte gradiente redox, e são verticalmente estratificados em uma previsível ordem de diferentes zonas oxidativas (Kristensen, 2000). Dependendo da presença e disponibilidade dos aceptores terminais de elétrons, a MO é mineralizada por diferentes tipos de bactéria e as variações da comunidade bacteriana com a profundidade do sedimento são geralmente resultado de mudanças no potencial redox da coluna sedimentar (Urakawa et al., 2000; Braker et al., 2001; Edlund et al., 2008; Böer et al., 2009). Entretanto, essas zonas não se formam em todos os locais e dependem, por exemplo, da penetração do oxigênio no sedimento, do tipo de sedimento, da deposição da MO, de feições químicas específicas, do sítio e de distúrbios físicos. Distúrbios físicos, como eventos de ressuspensão, podem levar a uma mistura das zonas previamente encontradas no sedimento, formando um 
padrão aleatório de manchas com diferente condição redox e diferentes aceptores de elétrons ocorrendo muito próximos na "ordem errada" (Zehnder \& Stumm, 1988). Dessa forma, diferentes bactérias com diferentes metabolismos são capazes de ocorrer em uma mesma camada do sedimento, aumentando a diversidade bacteriana nesses locais. Adicionalmente, a mudança no padrão vertical das condições químicas do sedimento após a ressuspensão leva a uma mudança também na distribuição das bactérias entre as camadas do sedimento.

Como conclusão, foi observado que a ressuspensão do sedimento atua de forma importante na distribuição da matéria orgânica e da comunidade microbiana nos sedimentos marinhos. $\mathrm{O}$ evento de ressuspensão foi responsável por um estímulo da comunidade procariótica aumentando não só a densidade total dos organismos, mas também a densidade de células vivas, levando adicionalmente a um aumento na diversidade bacteriana em todas as camadas imediatamente após o evento. Além disso, a provável mudança nas concentrações químicas do sedimento levou a mudanças importantes na estrutura da comunidade e na sua distribuição na coluna sedimentar. 


\section{Capitulo 6: Diversidade bacteriana de sedimentos marinhos costeiros acessado através de bibliotecas genômicas.}

\subsection{Introdução}

Organismos procariotos (Bacteria e Archaea) que vivem em sedimentos marinhos participam da maior parte dos processos envolvendo ambos compostos inorgânicos e orgânicos, apresentando altas densidades, biomassa e diversidade. Estudar a diversidade genética e analisar os membros que compõem as diversas populações são passos importantes no estudo envolvendo as comunidade microbianas (Ghost et al., 2010). Durante as últimas décadas, o desenvolvimento de técnicas moleculares usando ácidos nucléicos tem levado a muitos novos achados no estudo da ecologia microbiana marinha (Kemp \& Aller, 2004). Uma abordagem básica para conhecer as comunidades microbianas é o estudo de genes 16S do rRNA amplificados através da PCR do DNA extraído diretamente a partir de amostras ambientais, para posterior clonagem e sequenciamento (Ghost et al., 2010).

Análises da composição da comunidade bacteriana têm sido realizadas em muitos sedimentos de diferentes ambientes, como na Antártica e no Ártico (Bowman et al., 2003a,b; Llobet-Brossa et al., 1998; Ravenschlag et al., 1999, 2000, 2001), em mar profundo (Huber et al., 2007; Heijs et al., 2008; Polymenakou et al., 2005a, 2009; Shäfer et al., 2007; Kouridaki et al., 2010) e regiões costeiras (Al-Sayed et al., 2005; Musat et al., 2006; Gomes et al., 2008). Porém, muito pouco se conhece sobre a comunidade bacteriana em sedimentos marinhos do Atlântico Sul e nenhum estudo anterior a esse foi realizado na área estudada.

Enquanto vários estudos têm observado que a composição da comunidade microbiana sedimentar de diferentes partes do mundo mostra uma predominância de certos grupos filogenéticos, como Delta- e Gammaproteobacteria, e as sequências retiradas de diferentes hábitats frequentemente mostram similaridades acima de $90 \%$ no nível de Classe/Filo (Köchling et al., 2012). Quando examinadas mais profundamente, as bibliotecas de clones representam um alto nível de biodiversidade, incluindo muitos ribotipos únicos (Bowman et al., 2000). Isso demonstra que, resumidamente, os mesmos grupos filogenéticos parecem ser encontrados no sedimento independente de sua 
localização geográfica. Porém, o nível de diversidade dentro de cada grupo de sequências pode ser altamente variável.

O presente estudo visou determinar a composição da comunidade bacteriana em amostras do sedimento costeiros na região de Ubatuba, litoral norte do estado de São Paulo. O objetivo foi observar a diversidade e composição da comunidade bacteriana após a realização de dois tratamentos experimentais: (1) enriquecimento orgânico e (2) ressuspensão, no sedimento superficial marinho. Foi estudada a diversidade microbiana através da clonagem e análise de sequenciamento baseada no gene16S do rRNA. Sete bibliotecas genômicas foram construídas permitindo uma detalhada análise filogenética.

\subsection{Material e Métodos}

\subsubsection{Amostragem}

As amostras foram retiradas de dois experimentos realizados com sedimento da região costeira de Ubatuba (aproximadamente $40 \mathrm{~m}$ de profundidade). $\mathrm{O}$ primeiro experimento envolveu a adição de duas espécies de microalgas na superfície do sedimento e o segundo simulou a ressuspensão do sedimento. Um total de sete amostras foi escolhido para a realização das bibliotecas genômicas. Do primeiro experimento foram escolhidas as amostras referentes ao tratamento com Tetrasselmis e Phaeodactylum nos tempos de 24 h e 48 h após a adição das microalgas. Com isso foi possível observar mudanças na comunidade devido aos diferentes tratamentos de adição de diferentes algas à superfície do sedimento. Do segundo experimento foram escolhidas as amostras referentes ao tratamento com ressuspensão nos tempos $48 \mathrm{~h}$ e 120 h e do controle 120 h, sendo possível observar como a comunidade bacteriana foi afetada pela ressuspensão do sedimento.

\subsubsection{Extração, PCR e construção das bibliotecas genômicas}

A extração de DNA das amostras de sedimento foi realizada utilizando o PowerSoil DNA Isolation Kit (MoBio Laboratoires, CA, USA) de acordo com as especificações do fabricante. O DNA extraído foi quantificado e sua pureza checada através de medidas de absorbância com espectrofotômetro. O gene $16 \mathrm{~S}$ rDNA foi amplificado para a construção das bibliotecas genômicas usando os primers 27F/1401R (Lane, 1991). As reações de cadeia de polimerase (PCR) foram realizadas através de um termociclador (Eppendorf Mastercycler Personal) e todos os produtos da PCR foram 
verificados por eletroforese em gel de agarose 1,5\% (p:v) em TAE $1 \mathrm{X}$ a $100 \mathrm{~V}$, corados com brometo de etídeo, expostos a um transiluminador UV, visualizados e fotografados no software de imagens Kodak 1D 3.6 (Kodak). A mistura para as reações de PCR em um total de $50 \mu \mathrm{l}$ consistiu de: $1 \mu \mathrm{l}$ de DNA extraído, 1X PCR Buffer (Invitrogen), 1,7 $\mathrm{mM} \mathrm{MgCl2,} \mathrm{0,25} \mathrm{mM} \mathrm{dNTPs,} \mathrm{0,3} \mu \mathrm{M}$ primers, $1 \mathrm{U}$ Taq DNA polymerase (Platinun, Invitrogen), água livre de ácido nucléico até completar o volume. A amplificação de fragmentos do tamanho esperado e sua quantificação foram determinadas pela comparação com o marcador de massa moleculares DNA ladder - Low Mass (Invitrogen).

Os produtos de PCR após purificação foram clonados usando o TOPO TA cloning Kit (Invitrogen,Carlsbad,CA,USA) como recomendado pelo fabricante. Após transformação, os produtos foram clonados usando as células competentes de Escherichia coli Top 10 (Invitrogen) transformadas com $2 \mathrm{~mL}$ da reação de ligação utilizando-se o método de heat shock (incubação a $42{ }^{\circ} \mathrm{C}$ por 45 segundos seguido de incubação por 2 minutos em gelo). Duzentos e cinquenta microlitros de meio SOC foi adicionado às células e incubado por 1 hora a $37^{\circ} \mathrm{C}$. Células de E. coli transformantes, contendo o inserto de DNA, foram selecionadas pelo crescimento de colônias em meio sólido contendo X-Gal, proporcionando uma seleção do tipo "Blue-White", sendo as colônias brancas as que continham o DNA clonado. Clones positivos foram re-crescidos em placas com meio LB, seguido por extração do fragmento através de lise com meio Tris-HCl. Os produtos clonados foram re-amplificados por PCR utilizando o primer M13F-1401R. Os produtos de PCR foram checados quanto ao tamanho em gel de agarose $1,5 \%$ e comparados com o marcador de massa molecular 1000 pb (Invitrogen). Os produtos de PCR foram purificados com PureLink ${ }^{\mathrm{TM}}$ PCR Purification Kit (Invitrogen) e quantificados em espectrofotômetro. Um total de 80 clones de cada amostra foram enviados para sequenciamento usando o BigDye Terminator v3.1 Cycle Sequencing Kit (Applied Biosystems) pela empresa Genomic Engenharia Molecular, usando o primer universal T7.

\subsubsection{Análise filogenética}

As sequências de DNA foram editadas com o programa Bio-Edit Sequence Alignment Editor e alinhadas com o programa Clustal W software (http://www.ebi.ac.uk/clustalw). Após retirada das sequências curtas e de baixa 
qualidade, um total de 498 sequências foram comparadas às depositadas no GenBank utilizando Blast (http://www.ncbi.nlm.nih.gov/BLAST).

\subsection{Resultados}

A afiliação taxonômica das sequências clonadas seguindo análises comparativas com gene 16S rRNA revelaram um alto grau de diversidade nos sedimentos analisados, refletida na presença de organismos pertencentes a 15 diferentes filos do domínio Bactéria. A filogenia completa das sequências analisadas, mostrando o organismo mais similar encontrado no GenBank é apresentada em uma Tabela no ANEXO.

O grupo mais numeroso detectado foi o filo Proteobacteria, representando $75 \%$ do total dos clones sequenciados. Membros de todas as classes do filo foram encontrados, Gamma-, Delta- e Alphaproteobacteria foram encontrados em todas as amostras e representaram $32 \%, 22 \%$ e $20 \%$ respectivamente, do total de sequências. Bacteroidetes foi o segundo filo mais abundante, compreendendo $6 \%$ dos filotipos encontrados. Cloroflexi, Cyanobacteria, Actinobacteria, Firmicutes e Fusobacteria compreenderam $5 \%, 3 \%, 2 \%$ e $1 \%$ do total de sequências, respectivamente. Os outros filos encontrados, Acidobacteria, Verrucomicrobia, Caldithrix, Chlorobi, Nitrospirae, Planctomycetes e Spirochaetes foram representados por uma ou duas sequências dentre todas.

Gammaproteobacteria foi o grupo mais abundante dentre as sequências, apresentando um alto número de espécies em todas as amostras estudadas, sendo o grupo mais numeroso nas amostras Phaeodactylum $24 \mathrm{~h}$, Ressuspensão $120 \mathrm{~h} \mathrm{e}$ Controle 120 h, representando $28 \%, 20 \%$ e $46 \%$ do total de sequências, respectivamente (Figura 6.1). Alphaproteobacteria foi o segundo grupo mais numeroso entre as sequências analisadas e também apresentou representantes em todas as amostras, sendo que Tetrasselmis $24 \mathrm{~h}$ e $48 \mathrm{~h}$ apresentaram a maior parte das sequências pertencentes a esse grupo com $43 \%$ e $40 \%$, respectivamente (Figura 6.1). As amostras Phaeodactylum $48 \mathrm{~h}$ e ressuspensão $48 \mathrm{~h}$ apresentaram mais representantes do grupo Deltaproteobacteria ( $27 \%$ e $39 \%$, respectivamente), que também foi encontrado em todas as amostras. O único filo fora as Proteobactéria encontrado em todas as amostras foi o Bacteroidetes. Este filo apresentou um alto número de organismos em Phaeodactylum $24 \mathrm{~h}$ representando $14 \%$ das sequências da amostra. Já a amostra ressuspensão $48 \mathrm{~h}$ apresentou apenas $1,4 \%$ de representantes pertencentes aos 
Bacteroidetes (Figura 6.1). Dentro desse filo, as classes Flavobacteria e Cytophagia representaram a maior parte dos organismos encontrados.

O filo Cloroflexi foi também abundante e só não foi encontrado na amostra Tetrasselmis $48 \mathrm{~h}$, apresentando a maior parte dos organismos pertencentes ao grupo Anaerolineae. Firmicutes e Actinobacteria só não foram encontrados em duas amostras e apresentaram representantes principalmente dos grupos Clostridia e Actinobacteridae. O grupo Actinobacteria representou $11 \%$ das sequências na amostra Phaeodactylum 48 h, mostrando poucos representantes no restante das amostras. Os outros grupos encontrados foram representados por poucos organismos. A amostra Phaeodactylum 24 $\mathrm{h}$ foi a que apresentou a maior diversidade de grupos relacionados, apresentando representantes de 13 dos 19 grandes grupos encontrados (Figura 6.1). Enquanto a amostra ressuspensão $48 \mathrm{~h}$ apresentou representantes pertencentes a apenas 7 grupos dos encontrados, mostrando a menor diversidade (Figura 6.1).

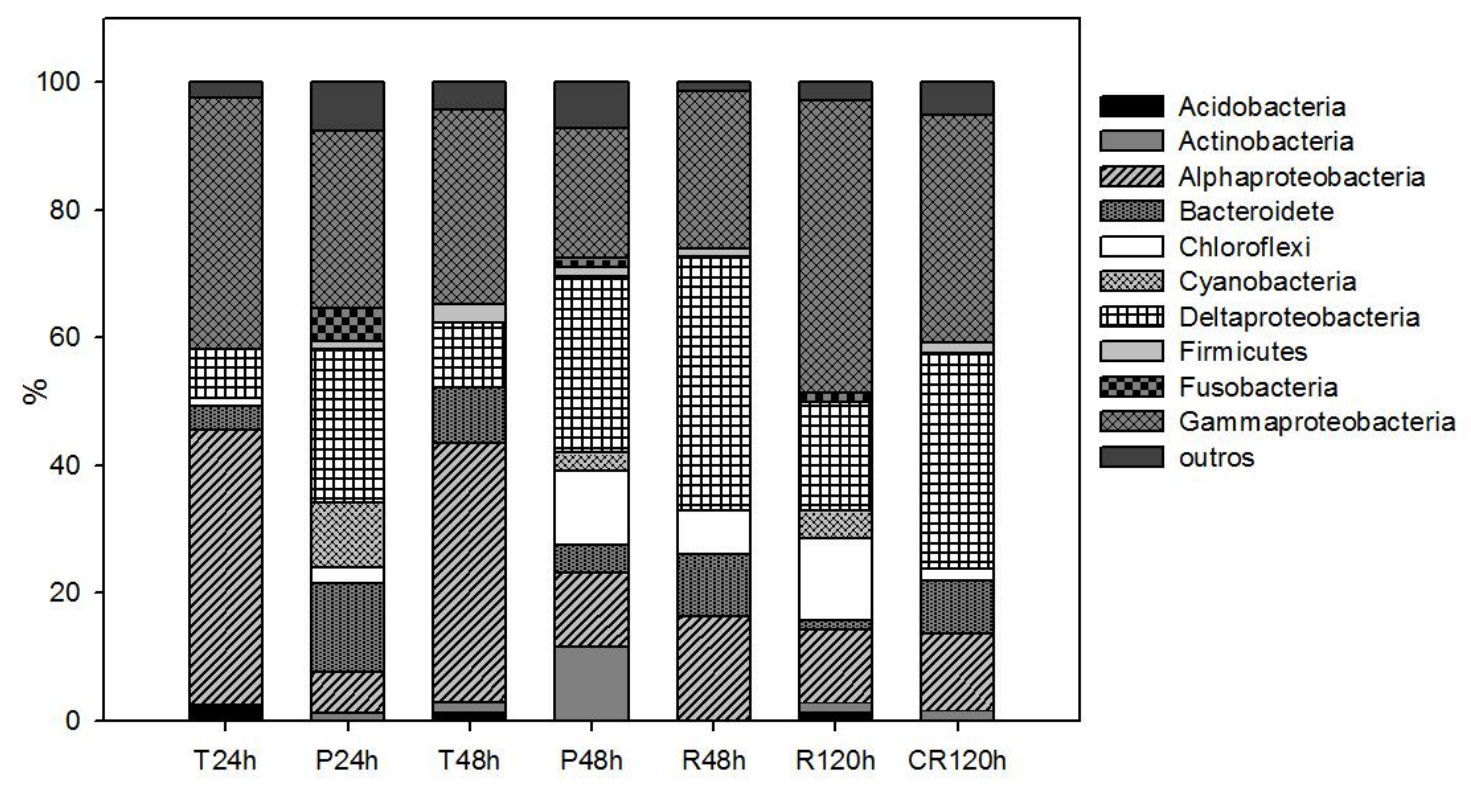

Figura 6.1: Abundância relativa sequências pertencentes às diferentes linhagens filogenéticas dentro das sete amostras de sedimento. T. Tetrasselmis; P. Phaeodactylum; R. Ressuspensão; CR. Controle do experimento de ressuspensão. 


\subsection{Discussão}

Nas últimas décadas, nosso conhecimento sobre a diversidade microbiana tem se expandido dramaticamente, devido principalmente ao sequenciamento de genes clonados diretamente de DNA ambiental (Amam, 1995; Pace, 1997; DeLong \& Pace, 2001; Rappé \& Giovannoni, 2003). A composição da comunidade bacteriana em vários sedimentos tem sido investigada principalmente com a construção de bibliotecas genômicas de 16S rRNA (e.g. Al-Sayed et al., 2005; Polymenakou et al., 2009; Kolukirik et al., 2011). Essas bibliotecas têm revelado que Alpha-, Gamma- e Deltaproteobacteria, Acidobacteria, Bacteriodetes e Planctomycetes apresentam uma vasta distribuição na maioria dos ambientes marinhos.

Embora análises da diversidade microbiana baseadas em bibliotecas de clones possam não representar totalmente a comunidade natural devido aos vieses associados à formação de quimeras e mutações induzidas pela PCR e à fraqueza do método em amplificar os micro-organismos com baixa densidade, o método continua sendo um dos mais eficazes em identificar a maior parte dos micro-organismos mais abundantes do ecossistema (Polymenakou et al., 2009). Nosso estudo identificou a presença de 206 diferentes filotipos dentre as 498 sequências analisadas, mostrando um grau de riqueza semelhante a outros estudos em sedimentos marinhos (Polymenakou et al., 2009; Kolukirik et al., 2011). Apesar da dificuldade geralmente encontrada nos estudos com a comunidade microbiana para avaliar a real diversidade da comunidade e do presente estudo ter se baseado em apenas poucas sequências de cada amostra (máximo de 80 sequências), a alta diversidade encontrada no sedimento costeiro da região é evidente, com 15 diferentes filos do grupo Bactéria.

Proteobacteria foi o filo altamente dominante nas amostras, representando mais de $70 \%$ dos organismos encontrados, o que confirma a predominância desse grupo no sedimento marinho, como observado em vários estudos anteriores (Gray \& Herwig, 1996; Bowman et al., 2000; Polymenakou et al., 2009; Köchling et al., 2011). Dentro de Proteobacteria, os três principais grupos Alpha- Gamma- e Delta- ocorreram em alta porcentagem com diferentes dominâncias nas diferentes amostras estudadas.

Alphaproteobacteria foi o grupo dominante nas amostras com o tratamento Tetrasselmis, apesar de ter sido encontrado em todas as amostras. Esse grupo geralmente é encontrado em altas densidades na coluna d'água de regiões costeiras (Gonzáles et al., 1997; Stevens et al., 2005), porém não é encontrado em altas 
densidades e diversidade em sedimentos marinhos. Quando encontrado nos sedimentos, esse grupo é geralmente relacionado a regiões costeiras apresentando alta produtividade, sendo observada uma alta relação entre a riqueza de Alphaproteobacteria e o nível de produtividade encontrado (Horner-Devine et al., 2003; Polymenakou et al., 2009). Dessa forma, a alta riqueza desse grupo encontrada nessas amostras parece estar altamente relacionada ao input de Tetrasselmis realizado, o que parece ter levado ao aumento de organismos pertencentes à Alphaproteobacteria nos sedimentos superficiais. Adicionalmente, esse grupo parece ser altamente encontrado na coluna d'água geralmente associado ao florescimento fitoplanctônico (Grossart et al., 2005; Rink et al., 2007).

O grupo Gammaproteobacteria foi o mais encontrado de um modo geral nas amostras de sedimento analisadas, representando mais de $20 \%$ dos organismos em todas as amostras. A dominância desse grupo no sedimento tem sido observada para uma variedade de hábitats de regiões frias e quentes, de costeiras a mar profundo. Bowman \& McCuaig (2003), por exemplo, construíram uma grande biblioteca de clones 16S para observar a diversidade de procariotos em sedimentos superficiais da Antártica e observaram uma grande dominância do grupo Gammaproteobacteria. Ghost et al. (2010) encontraram altas densidades e diversidade desse grupo em manguezais impactados. Kato et al. (1997) observaram dominância de Gammaproteobacteria nas sequências do domínio Bactéria na fossa das Marianas, o ponto mais profundo do oceano. O sucesso das Gammaproteobacteria em colonizar diferentes áreas está principalmente associado à sua grande diversidade metabólica (Madigan et al., 1997).

Outro grupo altamente dominante foi Deltaproteobacteria, que apresentou suas maiores densidades nas amostras do experimento de ressuspensão, principalmente nas amostras ressuspensão $48 \mathrm{~h}$ e controle 120 h. A maioria das Deltaproteobacteria é redutora de sulfato, um dos percursos de metabolismo mais importantes nos sedimentos marinhos que ocorrem em condições anaeróbicas (Ravenschlag et al., 2000; LópezGarcía et al., 2003). Entretanto, bactérias redutoras de sulfato, esperadamente restritas a ambientes anóxicos, também estão presentes na camada superficial óxica em número bem elevado, como o observado nas amostras analisadas (Sas et al., 1997; Sahm et al., 1999a) e até na coluna d'água (Stevens et al., 2005). Sahm et al. (1999b) reportaram que $20 \%$ do total de procariotos em sedimentos marinhos costeiros foram originados de bactérias sulfatorredutoras, o mesmo valor observado no presente estudo. Adicionalmente, bactérias redutoras de sulfato apresentam uma grande diversidade 
metabólica, podendo utilizar uma variedade de recursos de carbono, tais como diferentes ácidos graxos, alcoóis e compostos aromáticos, permitindo sua ampla distribuição em diferentes hábitats (Devereux et al., 1992; Elsabé et al., 2012). O aumento desse grupo relacionado a eventos de ressuspensão, como o encontrado no presente trabalho, também foi observado em outros estudos (Stevens et al., 2005).

O grupo Bacteroidetes foi também encontrado em todas as amostras analisadas, apresentando maiores densidades na amostra Phaeodactylum 24h. Os Bacteroidetes ocorrem praticamente em todo o ambiente aquático e em ambientes marinhos eles são frequentemente detectados (Llobet-Brossa et al., 1998; Bowman et al., 2003a). Esse grupo tipicamente contém organismos com habilidades hydrolíticas fermentativas, sendo quimiorganotróficos e especialmente eficientes na degradação de vários polímeros, tais como celulose, quitina e pectina (Weller et al., 2000). Bacteriodetes são também encontrados em amostras de sedimento e parecem ser um grupo importante na degradação do carbono derivado de fitoplâncton nos sedimentos (Rusch et al., 2003; Lai et al., 2006; Mills et al., 2008). Os membros dos grupos Cytophagia e Flavobacterium foram os mais abundantes nas amostras e são em geral altamente abundantes nos sedimentos marinhos, principalmente relacionados ao input de substâncias orgânicas complexas, sendo dominantes em ambientes com altas disponibilidades de carbono e altas taxas de remineralização (Rosselló-Mora et al., 1999; Ravenschlag et al., 2001; Fierer et al., 2007).

Sequências relacionadas ao grupo Cloroflexi também foram encontradas em quase todas as amostras analisadas. Esse grupo é reconhecido como uma divisão do grupo Bactéria apenas há poucas décadas e mesmo hoje essa divisão é ainda representada por apenas poucos isolados (Ikenaga et al., 2010). Os representantes cultivados desse grupo têm sido uma grande variedade de fenótipos de fotossintetizantes anoxigênicos (Cloroflexus) e organotrófos termofílicos (Thermomicrobium) (Hugenholtz et al., 1998). Estudos recentes, entretanto, têm observado a presença desses organismos em uma variedade de hábitats principalmente relacionados com água doce e manguezais (Piza et al., 2004; Ikenaga et al., 2010). Membros do grupo Cloroflexi também foram encontrados previamente em sedimentos marinhos, sempre apresentando poucos representantes (Polymenakou et al., 2009; Ghosh et al., 2010; Elsabé et al., 2012).

Outro grupo que apresentou importante presença em algumas amostras foi o Actinobacteria. Poucos estudos reportaram uma contribuição significativa dessas 
bactérias em bibliotecas de sedimentos marinhos (Stach \& Bull, 2005; Ward \& Bora, 2006). A presença de Actinobacteria no ecossistema marinho tem sido frequentemente atribuída a inputs terrestres (Piza et al., 2004). Entretanto, tem sido observado que Actinobactérias são um pequeno, mas significante grupo compondo o sistema marinho, apresentando uma boa distribuição e persistente ocorrência em sedimentos marinhos (Venter et al., 2004; Ward \& Bora, 2006; Polymenakou et al., 2009; Elsabé et al., 2012). Devido a sua variada distribuição, raramente membros desse grupo dominam as populações microbianas. Porém, sua alta habilidade fisiológica permite sua presença ativa em uma grande variedade de hábitats (Elsabé et al., 2012). Muitas questões continuam por ser respondidas ao que diz respeito às funções ecológicas de Actinobacteria no ambiente marinho, bem como sua distribuição geográfica e história evolutiva (Polymenakou et al., 2009).

Outros grupos que foram encontrados na maior parte das amostras foram Cyanobacteria, Firmicutes, Acidobacteria e Planctomycetes. Cyanobacteria é um grupo geralmente encontrado em grandes densidades na coluna d'água de ambientes marinhos, porém sua presença no sedimento também foi observada em outros estudos (Ikenaga et al., 2010). Firmicutes é um grupo importante de bactérias gram-positivas e tem sido frequentemente encontrado dominando os sedimentos superficiais de ambientes anóxicos (Urakawa et al., 1999; Köchling et al., 2011). Portanto, foi normal não termos encontrado uma grande densidade desses organismos no presente estudo. Membros do grupo Acidobacteria têm sido observados principalmente em solos e ambientes terrestres, porém novos estudos têm demonstrado que esse grupo é capaz de crescer em uma grande variedade de ambientes, inclusive marinhos (Barns et al., 1999). Organismos pertencentes ao grupo Acidobacteria também foram encontrados em sedimentos marinhos em baixa densidade (Köchling et al., 2011). Planctomycetes foram encontradas em baixa densidade, mas na maioria das amostras mostrando sua distribuição variada. Esse grupo é capaz de oxidar substratos orgânicos através da redução de nitrato (Fuerst, 1995) e também alguns são capazes de fermentação ácida (Glöckner et al., 2003) e têm sido encontrados em sedimentos marinhos (Elsabé et al., 2012; Köchling et al., 2011).

Enquanto os estudos com métodos independentes de cultivo têm aumentado grandemente no ambiente marinho, a descrição filogenética da diversidade bacteriana permanece incompleta. Está claro que os estudos adicionais com as sequências genômicas têm continuamente se acumulados nas bases de dados, e muitas novas 
divisões têm sido reconhecidas no domínio Bactéria. Porém, os estudos no Brasil ainda são muito escassos e se concentram principalmente na coluna d'água e sedimento de mangues, o que limita a possibilidade de comparação com ambientes semelhantes ao do presente estudo. O estudo mostrou que a comunidade bacteriana da área estudo apresenta uma grande diversidade quando comparada com outros sedimentos marinhos estudados ao longo do oceano global. A dominância do grupo Proteobacteria nos sedimentos foi confirmada, principalmente do grupo Gammaproteobacteria que parece ser o mais abundante e diverso no sedimento marinho costeiro. Os diferentes tratamentos realizados nos dois experimentos estudados também mostraram que a comunidade bacteriana é influenciada tanto por eventos de enriquecimento orgânico como por eventos de ressuspensão. Diferentes tipos de algas chegando ao sedimento podem levar a uma maior dominância de diferentes bactérias na superfície do sedimento, como Alphaproteobacteria sendo mais associada à chegada de material derivado de fitoflagelados, enquanto Bacteroidetes e Deltaproteobacteria parecem ser mais estimuladas pela chegada de diatomáceas. A ressuspensão parece atuar também na composição da comunidade bacteriana, principalmente aumentando a porcentagem de membros do grupo Deltaproteobacteria, que podem ser levados das regiões mais profundas do sedimento para a superfície após a mistura sedimentar. 


\section{Capítulo 7: Considerações finais}

Sedimentos marinhos compreendem um dos locais mais complexos da Terra e os micro-organismos participam da maior parte dos processos biogeoquímicos que ocorrem nesses ambientes. Entretanto, o conhecimento dos processos oceanográficos que influenciam esses organismos no ambiente bentônico ainda é controverso e necessitam de profundos estudos para que se entendam as complexas interações existentes. Uma maneira muito utilizada de estudar a influência do ambiente em organismos específicos é através de estudos experimentais realizados em condições laboratoriais. Apesar de apresentar uma visão simplificada do complexo ambiente estudado, o uso de experimentos permite o conhecimento de como uma variável específica influencia diretamente o ambiente, sem a interferência de outras variáveis. Isso permite que suposições levantadas em estudos ambientais sejam comprovadas e hipóteses diretas sejam testadas cientificamente.

O presente estudo teve como objetivo observar de que modo dois eventos naturais influenciam a comunidade microbiana do sedimento. Para isso, dois experimentos foram realizados separadamente: o primeiro foi realizado com o intuito de observar a influência da chegada de alimento fresco de origem fitoplanctônica diverso; o segundo, para observar os efeitos de eventos de ressuspensão do sedimento causado por ondas e correntes.

\subsection{Efeito da matéria orgânica particulada derivada do plâncton na comunidade microbiana do sedimento}

A influência da quantidade e qualidade da matéria orgânica nos organismos bênticos é bem conhecida. A chegada de matéria orgânica lábil no ambiente gera um aumento na densidade dos organismos e os micro-organismos parecem responder rapidamente a essa chegada de alimento no sedimento. No presente estudo, a adição das microalgas levou a um aumento quase que imediato (dentro de $48 \mathrm{~h}$ ) na densidade total e de células viáveis dos procariotos presentes no sedimento, confirmando o que já era pensado anteriormente. Porém, uma nova observação foi que as diferentes microalgas adicionadas levaram a diferentes velocidades de resposta dos micro-organismos. A chegada de material derivado de um fitoflagelado (i.e. Tetrasselmis) levou a um aumento quase imediato na densidade procariótica (após 24 h) de cerca de $20 \%$ na 
densidade total e $25 \%$ na quantidade de células viáveis. Já a adição de matéria orgânica derivada de uma diatomácea (Phaeodactylum tricornutum) levou uma resposta mais demorada dos micro-organismos (após 48 h). Porém, o aumento foi mais pronunciado de cerca de $28 \%$ para a densidade total e de $48 \%$ para células viáveis. A maior facilidade de degradação do fitoflagelado em relação à diatomácea está relacionada à presença de uma teca silicosa nesta última, que dificulta a degradação microbiana gerando um lapso na resposta medida. Apesar da mesma quantidade de clorofila-a ter sido introduzida nos experimentos, uma maior quantidade de matéria orgânica total foi adicionada no experimento com a diatomácea, levando a um maior aumento na densidade procariótica do que quando os fitoflagelados foram adicionados. Dessa forma, não só a quantidade e a qualidade do alimento, mas também suas origens específicas parecem influenciar de forma diferente a resposta microbiana do sedimento.

Essa diferença de resposta devido à adição das diferentes microalgas também foi observada na composição específica das comunidades bacterianas do sedimento. A análise de DGGE através da amplificação do gene 16S rRNA da comunidade bacteriana mostrou que a quantidade de clorofila-a do sedimento leva a mudanças específicas na comunidade bacteriana, observado pelas mudanças gradativas da comunidade ao longo do tempo de amostragem após o inicio do experimento. Porém, nos períodos logo após a adição das algas $(24 \mathrm{~h}$ e $48 \mathrm{~h}$ ), foram observadas diferenças na composição da comunidade bacteriana tanto entre os tratamentos quanto entre tratamentos e controle. $\mathrm{O}$ que confirma que a chegada de alimento de diferentes algas ao sedimento leva a respostas diferentes da comunidade microbiana sedimentar, também em nível específico. Essas diferenças foram bem evidenciadas após confecções de bibliotecas genômicas de bactérias nas amostras com os tratamentos após $24 \mathrm{~h}$ e 48 h de experimento. As bibliotecas mostraram que diferentes grupos de bactérias dominam a comunidade bacteriana após a adição das diferentes algas. Alphaproteobacteria foi o grupo dominante nas amostras após a adição de fitoflagelados, seguido de Gammaproteobactéria, representando juntos mais de $80 \%$ comunidade bacteriana. A quantidade consideravelmente menor de organismos do grupo Alphaproteobacteria encontrada nas outras amostras revela que a presença de matéria orgânica derivada especificamente de fitoflagelados estimula grandemente os membros desse grupo específico de bactérias. Já a adição de diatomáceas ao sedimento parece estimular um grupo mais diverso de comunidades bacterianas. Gammaproteobacteria e Deltaproteobacteria foram os mais abundantes grupos encontrados nas amostras com o 
tratamento, porém foi observado também um aumento nos organismos do grupo Bacteroidetes e a presença de indivíduos da maioria dos filos encontrada em todas as amostras analisadas.

Verticalmente na coluna sedimentar a distribuição dos micro-organismos parece não mostrar diferentes respostas devido à adição das diferentes algas. A estabilidade da coluna sedimentar devido à falta de distúrbios tanto físicos quanto biológicos levou a uma estabilidade também da comunidade bacteriana do sedimento.

\subsection{Efeito de eventos de ressuspensão na comunidade}

\section{microbiana do sedimento.}

Eventos de ressuspensão do sedimento são comuns em regiões costeiras, onde ondas e correntes de fundo são responsáveis por modificações nos parâmetros sedimentares e redistribuição partículas orgânicas e inorgânicas nas bacias oceânicas. Dessa forma, atuam diretamente também na estrutura e composição da comunidade microbiana do sedimento, o que foi confirmado pelos resultados apresentados no presente trabalho. Inicialmente a ressuspensão parece não levar a aumentos na densidade procariótica no sedimento, porém após certo tempo de estabilidade sedimentar há aumento significativo da densidade microbiana. Esse aumento da densidade tanto total quanto de células viáveis foi observado após 120 h do evento de ressuspensão e está principalmente relacionado ao aumento da matéria orgânica presente na superfície do sedimento, somado à volta da estabilidade do ambiente. A ressuspensão leva à redistribuição da matéria orgânica na coluna sedimentar, disponibilizando matéria orgânica lábil antes preservada nas camadas mais profundas do sedimento para a comunidade superficial, que apresenta altas taxas metabólicas. Essa mistura sedimentar levou também a um aumento na diversidade bacteriana do sedimento, mostrada pelas análises de DGGE, nas quais houve mudanças da comunidade bacteriana principalmente logo após a ressuspensão em relação ao controle. A ressuspensão parece ter levado a um atraso no padrão normal da estruturação da comunidade bacteriana, que voltou a ser altamente semelhante no fim do período experimental (i.e. após cerca de 30 dias). Dessa forma, a ressuspensão parece levar a uma desestruturação inicial da comunidade bacteriana, aumentando a quantidade de alimento lábil na superfície e atuando fisicamente na mistura do sedimento, porém com 
o tempo a estabilidade sedimentar retorna e a comunidade parece caminhar para uma estabilidade.

A mudança imediata na comunidade bacteriana após a ressuspensão foi confirmada pela composição observada nas bibliotecas genômicas realizadas com as amostras superficiais 48 h e 120 h após a ressuspensão e do controle após 120 h de experimento. Foi observado um grande aumento no número de organismos pertencentes ao grupo Deltaproteobacteria 48 h após a ressuspenão, o que já tinha sido observado no DGGE. Esse aumento demonstra o efeito de mistura sedimentar causado pelo evento, já que os organismos pertencentes a esse grupo são geralmente encontrados nas zonas anóxicas do sedimento. Porém, tanto Delta- quanto Gammaproteobactéria foram grupos encontrados em alto número em ambas as amostras, controle e tratamentos. Um grupo que pareceu ser mais estimulado pelo evento de ressuspensão foi o filo Cloroflexi, que apareceu em grande densidade após a ressuspensão, porém não no controle.

A ressuspensão parece afetar também significativamente a estrutura vertical da comunidade microbiana na coluna sedimentar. Após o evento, tanto a densidade procariótica quanto a estrutura da comunidade bacteriana apresentou mudanças com relação ao controle. A camada subsuperficial $(1-2 \mathrm{~cm})$ parece ter sido a mais modificada devido ao distúrbio, sofrendo um aumento tanto na densidade dos procariotos quanto na diversidade bacteriana do sedimento, resultando em maiores mudanças na estrutura da comunidade nessa camada. A oxigenação da coluna sedimentar e mudanças na cascata de reações redox ocorrendo verticalmente no sedimento foram os principais resultados da ressuspensão que afetaram a comunidade bacteriana do sedimento. Dessa forma, a ressuspensão parece afetar não só a comunidade da superfície do sedimento, mas também sua distribuição pela coluna sedimentar.

\subsection{Resposta às hipóteses iniciais}

Hipótese 1: A chegada de matéria orgânica particulada fresca no sedimento (produção fitoplanctônica) estimula a comunidade microbiana sedimentar

A adição das algas ao sedimento mostrou um aumento na densidade e atividade microbiana do sedimento. Dessa forma, a chegada de matéria orgânica particulada lábil de origem fitoplanctônica estimula a comunidade microbiana sedimentar, levando a um aumento tanto na densidade quanto na atividade dos micro-organismos do sedimento. 
Hipótese 2: A introdução de diferentes organismos fitoplanctônicos, e.g. diatomáceas e fitoflagelados, leva a diferentes respostas da comunidade microbiana do sedimento, tanto no tempo quanto na abundância específica das espécies

As diferentes algas adicionadas levaram a diferentes tempos de resposta da comunidade microbiana, levando a uma resposta mais rápida quando fitoflagelado foi adicionado, porém uma resposta mais acentuada após a chegada de diatomácea ao sedimento. A comunidade bacteriana também apresentou mudanças de composição de espécies quando as diferentes algas foram adicionadas, sendo que Alphaproteobactéria foi mais abundante após a chegada de fitoflagelado, enquanto as Gammaproteobacteria foram os mais numerosos após a adição de diatomáceas. Após a chegada de diatomácea ao sedimento foi observado um maior aumento na diversidade bacteriana do sedimento, quando comparado com a adição de fitoflagelado.

Hipótese 3: A ressuspensão do sedimento estimula o crescimento e metabolismo da comunidade microbiana do sedimento;

A ressuspensão foi responsável por um aumento na densidade e na atividade da comunidade microbiana no sedimento, principalmente devido ao aumento da oxigenação e da mistura da matéria orgânica sedimentar.

Hipótese 4: A estrutura da comunidade microbiana sedimentar é modificada após eventos de ressuspensão;

Após o evento de ressupensão foi observada uma mudanças na comunidade microbiana do sedimento, levando a um aumento da diversidade microbiana do sedimento. Esse aumento foi atribuído principalmente à mistura da coluna sedimentar, levando grupos microbianos antes em altas densidades nas regiões subsuperficiais para a superfície do sedimento.

Hipótese 5: As mudanças da estrutura da comunidade microbiana nos perfis da coluna sedimentar serão diferentes entre os dois experimentos realizados (enriquecimento algal $X$ ressuspensão)

Após o enriquecimento orgânico não foi observado grandes mudanças na comunidade bacteriana do sedimento quanto a sua distribuição vertical. $\mathrm{O}$ aumento do consumo de oxigênio na camada superficial do sedimento, somada ao aumento da 
estabilidade da coluna sedimentar devido à falta de distúrbios levou a uma estabilidade na distribuição dos micro-organismos na coluna sedimentar. Já a ressuspensão leva a um aumento na oxigenação da coluna sedimentar, e consequentemente na distribuição e consumo de outros compostos, levando também a mudanças na composição e distribuição das comunidades microbianas da coluna sedimentar.

Resumidamente o estudo apresentado gerou as seguintes conclusões:

- A chegada de matéria orgânica lábil ao sedimento aumenta a densidade e atividade bacteriana sedimentar;

- A composição específica do fitoplâncton chegando ao sedimento leva a diferenças na velocidade da resposta bacteriana sedimentar;

- Diferenças na composição específica do fitoplâncton levam também a estímulos de diferentes grupos bacterianos no sedimento;

- A ressuspensão é responsável por um aumento da densidade e atividade dos micro-organismos no sedimento, principalmente devido ao aumento da oxigenação e da mistura da matéria orgânica sedimentar;

- Eventos de ressuspensão levam a diferenças na comunidade bacteriana na superfície do sedimento, principalmente devido à mistura das comunidades ocorrendo em diferentes camadas do sedimento;

- Verticalmente, a estrutura da comunidade microbiana também é influenciada por eventos de ressuspensão, que leva a mudanças na distribuição das comunidades na coluna sedimentar;

- Gammaproteobacteria foi o grupo mais abundante de bactérias no sedimento costeiro de Ubatuba;

- Bactérias pertencentes ao grupo Alphaproteobacteria são altamente estimulados pela chegada do fitoflagelado Tetrasselmis sp. ao sedimento. 


\section{Referencias Bibliográficas}

Abell, G.C.J. \& Bowman, J.P. 2005. Colonization and community dynamics of class Flavobacteria on diatom detritus in experimental mesocosms based on Southern Ocean seawater. FEMS Microbiol. Ecol. 53: 379-391.

Abrams, P.A. 1995. Monotonic or unimodal diversityproductivity gradients: what does the competition theory predict? Ecology 76: 2019-2027.

Aidar, E.; Gaeta, S.A.; Gianesella-Galvão, S.M.F.; Kutner, M.B.B.; Teixeira, C. 1993. Ecossistema costeiro subtropical: nutrientes dissolvidos, fitoplâncton e clirofilaa e suas relações com as condições oceanográficas na região de Ubatuba, SP. Pub. Esp. Inst. Oceanogr., São Paulo 10: 9-43.

Aller, R.C. 1994. Bioturbation and remineralization of sedimentary organic matter: effects of redox oscillation. Chem. Geol. 114: 331-345.

Aller, R.C. 2001. Transport and Reactions in the Bioirrigated Zone, in: The Benthic Boundary Layer, edited by: Boudreau, B.P. \& Jorgensen, B.B. Oxford University Press. 269-301.

Almroth, E.; Tengberg, A.; Andersson, J.H.; Pakhomova, S.; Hall, P.O.J. 2009. Effects of resuspension on benthic fluxes of oxygen, nutrients, dissolved inorganic carbon, iron and manganese in the Gulf of Finland, Baltic Sea. Cont. Shelf Res. 29: 807-818.

Almroth-Rosell, E.; Tengberg, A.; Andersson, S.; Apler, A.; Hall, P.O.J. 2012. Effects of simulated natural and massive resuspension on benthic oxygen, nutrient and dissolved inorganic carbon fluxes in Loch Creran, Scotland. J. Sea Res. 72: 3848.

Al-Sayed, H.A.; Ghanem, E.H.; Saleh, K.M. 2005. Bacterial community and some physico-chemical characteristics in a subtropical mangrove environment in Bahrain. Mar. Pollut. Bull. 50: 147-155.

Alves, B. G. R. 2009. Dinâmica do acoplamento bento-pelágico na plataforma interna ao largo de Ubatuba (São Paulo, Brasil). Dissertação de Mestrado. Universidade de São Paulo, Instituto Oceanográfico, São Paulo. 87p.

Amann, R.I.; Ludwig, W.; Schleifer, K.H. 1995. Phylogenetic identification and in situ detection of individual microbial cells without cultivation. Microbiol. Ver. 59:143-169. 
Arfi, R. \& Bouvy, M. 1995. Size, composition and distribution of particles related to wind-induced resuspension in a shallow tropical lagoon. J. Plankton Res. 17: $557-574$.

Arin, L.; Marrasé, C.; Maar, M.; Peters, F.; Sala; M.M.; Alcaraz, M. 2002. Combined effects of nutrients and small-scale turbulence in a microcosm experiment. I. Dynamics and size distribution of osmotrophic plankton. Aquatic. Microb. Ecol. 29: $51-61$.

Arrigo, K.R., 2005. Marine microorganisms and global nutrient cycles. Nature 437: 349-355.

Azam, F.; Fenchel, T.; Field, J.G.; Gray, J.S.; Meyer-Reil, L.A.; Thingstad, F. 1983. The ecological role of water-column microbes in the sea. Mar. Ecol. Prog. Ser. 10: 257-263.

Azam, F,; Smith, D.C.; Steward, G.F.; Hagstrom, A. 1993. Bacteria-organic matter coupling and its significance for oceanic carbon cycling. Microb. Ecol. 28: 167-179.

Barns, S.M.; Shannon L. Takala, S.L.; Kuske, C.R. 1999. Wide distribution and diversity of members of the bacterial kingdom Acidobacterium in the environment. Appl. Environ. Microbiol. 65(4): 1731-1737.

Bauer, M.; Kube, M.; Teeling, H.; Richter, M.; Lombardot, T.; Allers, E.; Würdemann, C.A.; Quast, C.; Kuhl, H.; Knaust, F.; Woebken, D.; Bischof, K.; Mussmann, M.; Chudhuri, J.V.; Meyer, F.; Reinhardt, R.; Amann, R.; Glöckner, F.O. 2006. Whole genome analysis of the marine Bacteroidetes Gramella forsetii reveals adaptations to degradation of polymeric organic matter. Environ. Microbiol. 8: 2201-2213.

Berner, R.A. 1980. Diagenetic physical and biological processes. In: Holland, H.D. (Ed.), Early Diagenesis: A Theoretical Approach. Princeton University Press, Princeton, pp. 15-56.

Bissett, A.; Bowman, J.; Burke, C. 2006. Bacterial diversity in organically-enriched fish farm sediments. FEMS Microbiol. Ecol. 55:48-56.

Böer, S.I; Hedtkamp, S.I.C.; van Beusekom, J.E.E.; Fuhrman, J.A.; Boetius, A.; Ramette, A. 2009. Time- and sediment depth-related variations in bacterial diversity and community structure in subtidal sands. The ISME Journal. 3: 780791. 
Bordalo, A.A. 1993. Effects of salinity on bacterioplankton, field and microcosm experiments. J. Appl. Bacteriol. 75: 393-398.

Bowman, J.P. \& McCuaig, R.D. 2003. Biodiversity, community structural shifts, and biogeography of prokaryotes within Antarctic continental shelf sediment. Appl. Environ. Microbiol. 69: 2463-2483.

Bowman, J.P.; Rea, S.M.; McCammon, S.A.; McMeekin, T.A. 2000. Diversity and community structure within anoxic sediment from marine salinity meromictic lakes and a coastal meromictic marine basin, Vestfold Hilds, Eastern Antarctica. Environ. Microbiol. 2: 227-237.

Bowman, J.P.; Mancuso Nichols, C.A.; Gibson, J.A.E. 2003a. Algoriphagus ratkowskyi gen. nov., sp. nov., Brumimicrobium glaciale gen. nov., sp. nov., Cryomorpha ignava gen. nov., sp. nov. and Crocinitomix catalasitica gen. nov., sp. nov., novel flavobacteria isolated from various polar habitats. Int. J. Syst. Evol. Microbiol. 53, 1343-1355.

Bowman, J.P.; McCammon, S.A.; Gibson, J.A.; Robertson, L.; Nichols, P.D. 2003b. Prokaryotic metabolic activity and community structure in Antarctic continental shelf sediments. Appl. Environ. Microbiol. 69: 2448-2462.

Braker, G.; Ayala-del-Rio, H.L.; Devol, A.H.; Fesefeldt, A.; Tiedje, J.M. 2001. Community structure of Denitrifiers, Bacteria, and Arhcaea along redox gradients in Pacific Northwest Marine sediments by Terminal Restriction Fragment Length Polymorphism analysis of amplified nitrite reductase (nirS) and 16S rRNA genes. Appl Environ Microbiol 67: 1893-1901.

Brito, E.M.S.; Guyoneaud, R.; Goñi-Urriza, M.; Ranchou-Peyruse, A.; Verbaere, A.; Crapez, M.A.C.; Wasserman, J.C.A.; Duran, R. 2006. Characterization of hydrocarbonoclastic bacterial communities from mangrove sediments in Guanabara Bay, Brazil. Res. Microbiol. 157: 752-762.

Bussmann, I.; Hughes, J.; Wainright, S. 2001. Sediment resuspension and its effects on the turnover of methane, oxygen and carbon dioxide. Verh. - Int. Ver. Theor. Angew. Limnol. 27:1428-1431.

Byers, S.C.; Mills, E.L.; Stewart, P.L. 1978. A comparison of methods to determining organic carbon in marine sediments, with suggestion for a standard method. Hydrobiologia 58: 43-37.

Canfield, D.E. 1994. Factors influencing organic carbon preservation in marine sediments. Chem. Geol. 114: 315-329. 
Canfield, D.E.; Kristensen, E.; Thamdrup, B. 2005. The Sulfur Cycle. Advances in Marine Biology. 48: 313-381.

Canuel, E.A. \& Martens, C.S. 1996. Reactivity of recently deposited organic matter: degradation of lipid compounds near the sediment-water interface. Geochim. Cosmochim. Acta 60(10): 1793-1806.

Castro, B. M.; Lorenzzetti, J. A., Silveira, I. C. A. \& Miranda, L. B. 2006. -Estrutura Termohalina e Circulação na Região entre o Cabo de São Tomé (RJ) e o Chuí (RS)\|, O Ambiente Oceanográfico da Plataforma Continental e do Talude na Região Sudeste-Sul do Brasil. Ed. USP, pp.11-120.

Castro-Filho, B.M.; Miranda, L.B. \& Miyao, S.Y. 1987. Condições hidrográficas na plataforma continental ao largo de Ubatuba: variações sazonais e em média escala. Bolm. Inst. Oceanogr., São Paulo. 35(2): 135-151.

Chipman, L.; Podgorski, D.; Green, S.; Kostka, J.; Cooper, W.; Huettela, M. 2010. Decomposition of plankton-derived dissolved organic matter in permeable coastal sediments. Limnol. Oceanogr. 55(2): 857-871.

Christiansen, C.; Gertz, F.; Laima, M.J.C.; Lund-Hansen, L.C.; Vang, T. \& Jürgensen, C. 1997. Nutrient (P, N) dynamics in the southwestern Kattegat, Scandinavia: sedimentation and resuspension effects. Environ. Geol. 29 (1/2): 66-77.

Chròst, R.J. \& Riemann, B. 1994. Storm-stimulated enzymatic decomposition of organic matter in benthic/pelagic coastal mesocosms. Mar. Ecol. Progr. Ser. 108: $185-192$.

Conti, L.A. 2004. Geomorfologia da plataforma continental do Estado de São Paulo. Tese de Doutorado. Universidade de São Paulo, Instituto Oceanográfico, São Paulo. 241p.

Cook, P. L. M.; Veuger, B.; Böer1 S.; Middelburg, J. J. 2007. Effect of nutrient availability on carbon and nitrogen incorporation and flows through benthic algae and bacteria in near-shore sandy sediment. Aquat. Microb. Ecol. 49: 165180.

Cotner, J.B.; Johengen, T.H. \& Biddanda, B.A. 2000. Intense winter heterotrophic production stimulated by benthic resuspension. Limnol. Oceanogr. 45(7): 16721676. 
Danovaro, R.; Marrale, D.; Della Croce, N.; Parodi, P. \& Fabiano, M. 1999. Biochemical composition of sedimentary organic matter and bacterial distribution in the Aegean Sea: trophic state and pelagic-benthic coupling. $J$. Sea Res. 42: 117-129.

Del Giorgio, P. A., \& J. J. Cole. 2000. Bacterial energetics and growth efficiency, p. 289-325. In Kirchman, D.L. [ed.], Microbial ecology of the oceans. Wiley-Liss.

DeLong, E.F. \& Pace., N.R. 2001. Environmental Diversity of Bacteria \& Archaea, Systematic Biol. 50:1-9.

DeLong, E.F., 2005. Microbial community genomics in the ocean. Nature Rev. Microbiol. 3: 459-469.

Devereux, R.; Kane, M.D.; Winfrey, J.; Stahl, D.A. 1992. Genus- and group-specific hybridization probes for determinative and environmental studies of sulfatereducing bacteria. Syst. Appl. Microbiol. 15: 601-609.

Dietrich, D. \& Arndt, H. 2000. Biomass portioning of benthic microbes in Baltic inlet: relationships between bacteria, algae, heterotrophic flagellates and ciliates. Mar. Biol. 136: 309-322.

Du, J.; Xiao, K.; Huang, Y.; Li, H.; Tan, H.; Cao, L.; Lu, Y.; Zhou, S. 2011. Seasonal and spatial diversity of microbial communities in marine sediments of the South China Sea. Antonie van Leeuwenhoek. 100: 317-331.

Duarte, C.M.; Terrados, J.; Agawin, N.S.R.; Fortes, M.D.; Bach, S.; Kenworthy, W.J. 1997. Response of a mixed Philippine sea-grass meadow to experimental burial. Mar. Ecol. Prog. Ser. 147: 285-294.

Duarte, C.M.; Middelburg, J.J.; Caraco, N. 2004. Major role of marine vegetation on the oceanic carbon cycle. Biogeosc. 2:1-8.

Duport, E.; Stora, G.; Tremblay, T.; Gilbert, F. 2006. Effects of population density on the sediment mixing induced by the gallery-diffusor Hediste (Nereis) diversicolor. J. Exp. Mar. Biol. Ecol. 336: 33-41.

Eardly, D.F.; Carton, M.W.; Gallagher, J.M.; Patching, J.W. 2001. Bacterial abundance and ativity in deep-sea sediments from the eastern North Atlantic. Prog. Oceanogr. 50: 245-259.

Edlund, A.; Soule, T.; Sjöling, S.; Jansson, J.K. 2006. Microbial community structure in polluted Baltic Sea sediments. Environ. Microbiol. 8: 223-232. 
Edlund, A.; Hårdeman, F.; Jansson, J.K.; Sjöling, S. 2008. Active bacterial community structure along vertical redox gradients in Baltic Sea sediment. Environ. Microbiol. 10(8): 2051-2063.

Elsabé, J.M.; Brüchert, V.; Fuchs, B.M. 2012. Vertical shifts in the microbial community structure of organic-rich Namibian shelf sediments. Afr. Jour. Microbiol. Res. 6(17): 3887-3897.

Enocksson, V. 1993. Nutrient recycling by coastal sediments: effects of added algal material. Mar. Ecol. Prog. Ser. 22, 245-254.

Evrard, V.; Cook, P. L. M.; Veuger1, B.; Huettel, M.; Middelburg, J.J. 2008. Tracing carbon and nitrogen incorporation and pathways in the microbial community of a photic subtidal sand. Aquat. Microb. Ecol. 53: 257-269.

Fandino, L.B.; Riemann, L.; Steward, G.F.; Long, R.A. \& Azam, F. 2001. Variations in bacterial community structure during a dinoflagellate bloom analyzed by DGGE and 16S rDNA sequencing. Aquat. Microb. Ecol. 23: 119-130.

Fenchel, T. \& Finlay, B.J. 1995. Anaerobic environments. In: Ecology and Evolution in Anoxic Worlds. May, R.M. \& Harvey, P.H. (eds). Oxford, UK: Oxford University Press, pp. 27-28.

Fenchel, T.; King, G.M.; Blackburn, T.H. 1998. Bacterial Biogeochemistry: The Ecophysiology of Mineral Cycling. Academic.

Feng, B.W.; Li, X.R.; Wang, J.H.; Hu, Z.Y.; Meng, H.; Xiang, L.Y. 2009. Bacterial diversity of water and sediment in the Changjiang estuary and coastal area of the East China Sea. FEMS Microbiol. Ecol. 70: 80-92.

Fierer, N.; Bradford, M.A.; Jackson, R.B. 2007. Toward an ecological classification of soil bacteria. Ecology. 88: 1354-1364.

Findlay, R.H.; Trexler, M.B.; Guckerte, J.B.; White, D.C. 1990. Laboratory study of disturbance in marine sediments: response of a microbial community. Mar. Ecol. Prog. Ser. 62: 121-133.

Fiordelmondo, C.; Manini, E.; Gambi, C.; Pusceddu, A. 2003. Short-term impact of clam harvesting on sediment chemistry, benthic microbes and meiofauna in the Goro Lagoon (Italy). Chem. Ecol. 19: 173-187.

Fiordelmondo, C. \& Pusceddu, A. 2004. Short-term response of benthic bacteria and nanoflagellates to sediment resuspension: an experimental study. Chem. Ecol. 20(2): 107-121. 
Franco, M.A.; Mesel, I. De; Demba Diallo, M.; Van der Gucht, K.; van Gansbeke, D.; van Drijsvwijh, P.; Costa, M.J.; Vincx, M.; Vanaverbeke, J. 2007. Effect of phytoplankton bloom deposition on benthic bacterial communities in two contrasting sediments in the southern North Sea. Aquat. Microb. Ecol. 48: 241254.

Francos, M.S. 1996. Variações diárias sazonais (verão e inverno) do "standing stock" do fitoplâncton e da biomassa em termos de clorofila-a em duas estações fixas costeiras na região de Ubatuba: Lat. $23^{\circ} 31$ 'S - Long. $45^{\circ} 05^{\prime} \mathrm{W}$ e Lat. $23^{\circ} 51^{\prime} \mathrm{S}$ Long. 445' 'W. Dissertação de Mestrado, Instituto Oceanográfico, Universidade de São Paulo, 123p.

Franke, U.; Polerecky, L.; Precht, E.; Huettel, M. 2006. Wave tank study of particulate organic matter degradation in permeable sediments. Limnol. Oceanogr. 51(2): 1084-1096.

Frechette, M.; Demers, S.; Grant, J. 1988. An in situ estimation of the effect of winddriven resuspension on growth of the mussel, Mytilus edulis. J. Shell Fish Res. 7: 193-208.

Fromin, N.; Hamelin, J.; Tarnawski, S.; Roesti, D.; Jourdain-Miserez, K.; Forestier, N.; Teyssier-Cuvelle, S.; Gillet, F.; Aragno, M.; Rossi, P. 2002. Statistical analysis of denaturing gel electrophoresis (DGE) fingerprinting patterns. Environ. Microbiol. 4: 634-643.

Fuerst, J.A. 1995. The Planctomycetes: emerging models for microbial ecology, evolution and cell biology. Microbiology. 141: 1493-1506.

Fuhrman, J.A.; Hewson, I.; Schwalbach, M.S.; Steele, J.A.; Brown, M.V.; Naeem, S. 2006. Annually reoccurring bacterial communities are predictable from ocean conditions. PNAS. 103(35): 13104-13109.

Fukami, T. \& Morin, P.J. 2003. Productivity-biodiversity relationships depend on the history of community assembly. Nature. 424: 423-426.

Gaeta, S.A.; Abe, D.S.; Metlzler, P.M.; Teixeira, C. 1995. Photosynthetic parameters of coastal marine phytoplankton from the Ubatuba region, Brazil. Pub. Esp. Inst. Oceanogr., São Paulo, 11: 163-169.

Gaeta, S.A.; Ribeiro, S.M.S.; Metzler, P.M.; Francos, M.S.; Abe, D.S. 1999. Environmental forcing on phytoplankton biomass and primary productivity of the coastal ecosystem in Ubatuba region, southern Brazil. Rev. Bras. Oceanogr. 47: 11-27. 
Garstecki, T. \& Wickham, S.A. 2001. Effects of resuspension and mixing on population dynamics and trophic interactions in a model benthic microbial food web. Aquat. Microb. Ecol. 25: 281-292.

Garstecki, T.; Wickam, S.A.; Arndt, H. 2002. Effects of experimental sediment resuspension on a coastal planktonic microbial food web. Est. Coast. Shelf Sci. 55: 751-762.

Gaudette, H.E.; Flight, W.R.; Toner, L.; Folger, D.W. 1974. An inexpensive titration method for the determination of organic carbon in recent sediments. J. Sed. Petr. 44: 249-253.

Ghosh, A.; Dey, N.; Bera, A.; Tiwari, A.; Sathyaniranjan, K.B.; Chakrabarti, K.; Chattopadhyay, D. 2010. Culture independent molecular analysis of bacterial communities in the mangrove sediment of Sundarban, India. Saline Systems. 6: $1-11$.

Gihring, T. M.; Humphrys, M.; Mills, H. J.; Huettel, M.; Kostka, J.E., 2009. Identification of phytodetritus-degrading microbial communities in sublittoral Gulf of Mexico sands. Limnol. Oceanogr. 54: 1073-1083.

Glöckner, F.O.; Kube, M.; Bauer, M.; Teeling, H.; Lombardot, T.; Ludwig, W.; Gade, D.; Beck, A.; Borzym, K.; Heitmann, K.; Rabus, R.; Schlesner, H.; Amann, R.; Reinhardt, R. 2003. Complete genome sequence of the marine plantomycete Pirellula sp. Strain 1. Proc. Natl. Acad. Sci. USA. 100: 8298-8303.

Gomes, N.C.M.; Borges, L.R.; Paranhos, R.; Pinto, F.N.; Mendonça-Hagler, L.C.S.; Smalla, K. 2008. Exploring the diversity of bacterial communities in sediments of urban mangrove forests. FEMS Microbiol. Ecol. 66: 96-109.

González, J.M.; Mayer, F.; Moran, M.A.; Hodson, R.E.; Whitman, W.B. 1997. Sagittula stellata gen. nov., sp. nov., a lignin-transforming bacterium from a coastal environment. Int. J. Syst. Bacteriol. 47: 773-780.

Graf, G. 1992. Benthic-pelagic coupling - a benthic view. Oceanogr. Mar .Biol. 30: 149-190.

Gray, J.P. \& Herwig, R.P. 1996. Phylogenetic analysis of the bacterial communities in marine sediments. Appl. Environ. Microbiol. 62: 4049-4059.

Grossart, H.P.; Levold, F.; Allgaier, M.; Simon, M.; Brinkhoff, T. 2005. Marine diatom species harbour distinct bacterial communities. Environ. Microbiol. 7: 860873. 
Grossart, H.P. 1999. Interactions between marine bacteria and axenic diatoms (Cylindrotheca fusiformis, Nitzschia laevis, and Thalassiosira weissflogii) incubated under various conditions in the lab. Aquat. Microb. Ecol. 19: 1-11.

Haglund, A.; Törnblom, E.; Böstrom, B.; Tranvik, L. 2002. Large differences in the fraction of active bacteria in plankton, sediments, and biofilm. Microb. Ecol. 43: 232- 241 .

Haglund, A.; Lantz, P.; Törnblom, E.; Tranvik, L. 2003. Depth distribution of active bacteria and bacterial activity in lake sediment. FEMS Microb. Ecolo. 46: 3138.

Hansen, J.L.S. \& Josefson, A.B. 2003. Accumulation of algal pigments and live planktonic diatoms in aphotic sediments during the spring bloom in the transition zone of the North and Baltic Seas. Mar. Ecol. Progr. Ser. 248: 41-54.

Hartnett, H.E.; Keil, R.G.; Hedges, J.I.; Devol, A.H. 1998. Influence of oxygen exposure time on organic carbon preservation in continental margin sediments: Nature, 391: 572-574.

Haugland, R.P. 1996. Assays for cell viability, proliferation and function. In: Spence, M.T.Z. (Ed.), Handbook of Fluorescent Probes and Research Chemicals. Molecular Probes, Eugene, OR, pp. 365- 398.

Hedges, M.L. \& Keil, R.G. 1995. Sedimentary organic matter preservation: an assessment and speculative synthesis. Mar. Chem. 49: 81-115.

Hedges, J.I.; Hu, F.S.; Devol, A.H.; Hartnett, H.E.; Tsamakis, E.; Keil, R.G. 1999. Sedimentary organic matter preservation: a test for selective degradation under oxic conditions. Amer. J. Scien. 299: 529-555.

Heijs, S.K.; Laverman, A.M.; Forney, L.J.; Hardoim, P.R.; van Elsas, J.D. 2008. Comparison of deep-sea sediment microbial communities in the Eastern Mediterranean. FEMS Microbiol. Ecol. 64: 362- 377.

Hellström, T. 1991. The effect of resuspension on algal production in a shallow lake. Hydrobiology 213: 183- 190.

Henrichs, S.M. 1992. Early diagenesis of organic matter in marine sediments: progress and perplexity. Mar. Chem. 39: 119-149.

Hewson, I.; Vargo, G.A.; Fuhrman, J.A. 2003. Bacterial diversity in shallow oligotrophic marine benthos and overlying waters: effects of virus infection, containment, and nutrient enrichment. Microb. Ecol. 46: 322- 336. 
Hewson, I. \& Fuhrman, J.A. (2006). Spatial and vertical biogeography of coral reef sediment bacterial and diazotroph communities. Mar. Ecol. Prog. Ser. 306: 7986.

Hewson, I.; Jacobson/Meyers, M.E.; Fuhrman, J.A. 2007. Diversity and biogeography of bacterial assemblages in surface sediments across the San Pedro Basin, Southern California Borderlands. Environ. Microbiol. 9: 923- 933.

Hopkinson Jr., C.S. 1985. Shallow-water benthic and pelagic metabolism: evidence of heterotrophy in the nearshore Georgia bight. Mar. Biol. 87: 19- 32.

Horner-Devine, M.C.; Leibold, M.A.; Smith, V.H.; Bohannan, B.J.M. 2003. Bacterial diversity patterns along a gradient of primary productivity. Ecol. Lett. 6: 613622.

Horner-Devine, M.C.; Carney, K.M.; Bohannan, B.J.M. 2004. An ecological perspective on bacterial biodiversity. Proc. R. Soc. Lond. B. Biol. Sci. 271: 113122.

Huber, J.A.; Welch, D.B.M.; Morrison, H.G.; Huse, S.M.; Neal, P.R.; Butterfield, D.A.; Sogin, M.L. 2007. Microbial population structures in the Deep Marine Biosphere. Science 318: 97-100.

Huettel, M. \& Rusch, A. 2000. Transport and degradation of phytoplankton in permeable sediment. Limnol. Oceanogr. 45: 534-549.

Huettel, M.; Ziebis, W.; Forster, S.; Luther, G. 1998. Advective transport affecting metal and nutrient distribution and interfacial fluxes in permeable sediments. Geochim. Cosmochim. Acta 62: 613-631.

Hugenholtz, P.; Pitulle, C.; Hershberger, K.L.; Pace, N.R. 1998. Novel division level bacterial diversity in a Yellowstone hot spring. J. Bacteriol. 180: 366-376.

Ikenaga, M.; Guevara, R.; Dean, A.L.; Pisani, C.; Boyer, J.N. 2010. Changes in community structure of sediment bacteria along the Florida coastal everglades marsh-mangrove-seagrass salinity gradient. Microb. Ecol. 59: 284-295.

Inagaki, F.; Yuni, S.; Inoue, A.; Kato, C.; Horikoshi, K. 2002. Molecular phylogenetic analyses of reverse-transcribed bacterial rRNA obtained from deep-sea cold seep sediments. Environ. Microbiol. 4: 277-286.

Jensen, M. H.; Lomsten, E.; Sorensen, J. 1990. Benthic $\mathrm{NH}^{+}$and $\mathrm{NO}^{3-}$ flux following sedimentation of a spring phytoplankton bloom in Aarhus Blght, Denmark. Mar. Ecol. Prog. Ser. 61: 87-96. 
Jensen, M. M.; Thamdrup, B.; Dalsgaard, T. 2007. Effects of specific inhibitors on anammox and denitrification in marine sediments. Appl. Environ. Microbiol. 73(10): 3151-3158.

Jiang, L.; Zheng, Y.; Peng, X.; Zhou, H.; Zhang, C.; Xiao, X.; Wang, F. 2009. Vertical distribution and diversity of sulfate-reducing prokaryotes in the Pearl River estuarine sediments, Southern China. FEMS Microbiol. Ecol. 70: 249-262.

Jönsson, A.; Danielsson, A.; Rahm, L. 2005. Bottom type distribution based on wave friction velocity in the Baltic Sea. Cont. Shelf Res. 25: 419-435.

Kan, J.; Wang, K.; Chen, F. 2006. Temporal variation and detection limit of an estuarine bacterioplankton community analyzed by denaturing gradient gel electrophoresis (DGGE). Aquat. Microb. Ecol. 42: 7-18.

Karle, I.-M.; Agrenius, S.; Molander, S.; Magnusson, K.; Blanck, H.; Dahl, B.; Hall, P.; Dahllöf, I. 2007. Verification of a benthic boxcosm system with potential for extrapolating experimental results to the field. J. Exp. Mar. Biol. Ecol. 353: 265278.

Karner, M. \& Herndl, G.J. 1992. Extracellular enzymatic activity and secondary production in free-living and marine-snow-associated bacteria. Mar. Biol. 113: 341-347.

Kato, C.; Li, L.; Tamaoka, J.; Horikoshi, K. 1997. Molecular analyses of the sediment of the 11000-m deep Mariana Trench. Extremophiles 1:117- 123.

Kemp, P.F. \& Aller, J.Y. 2004. Bacterial diversity in aquatic and other environments: what 16S rDNA libraries can tell us. FEMS Microbiol. Ecol. 47: 161-177.

Kirchman, D.L. 2002. The ecology of Cytophaga-Flavobacteria in aquatic environments. FEMS Microbiol. Ecol. 39: 91-100.

Kirchman, D.L.; Malmstrom, R.R.; Cottrell, M.T. 2005.Control of bacterial growth by temperature and organic matter in the Western Arctic. Deep-Sea Res. II 52: 3386-3395.

Köchling, T.; Lara-Martín, P.; González-Mazo, E.; Amils, R.; Sanz, L. 2011. Microbial community composition of anoxic marine sediments in the Bay of Cádiz (Spain). Internat. Microbiol. 14: 143-154.

Kolukirik, M.; Ince, O.; Cetecioglu, Z.; Celikkol, S.; Ince, B.K. 2011. Spatial and temporal changes in microbial diversity of the Marmara Sea Sediments. Mar. Pol. Bul. 62: 2384-2394. 
Köster, M. \& Meyer-Reil, L.A. 2001. Characterization of carbon and microbial biomass pool in shallow water costal sediments of the southern Baltic Sea (Nordrügensce Bodden). Mar. Ecol. Prog. Ser. 214: 25-41.

Kouridaki, I.; Polymenakou, P.N.; Tselepides, A.; Mandalakis, M.; Smith Jr., K.L. 2010. Phylogenetic diversity of sediment bacteria from the deep Northeastern Pacific Ocean: a comparison with the deep Eastern Mediterranean Sea. Int. Microbiol. 13:143-150.

Kristensen E. 1993. Seasonal variations in benthic community metabolism and nitrogen dynamics in a shallow, organic-poor Danish lagoon. Estuar. Coast. Shelf Sci. 36: $565-586$.

Kristensen, E. 2000. Organic matter diagenesis at the oxic/anoxic interface in coastal marine sediments, with emphasis on the role of burrowing animals. Hydrobiologia 426: 1-24.

Kristensen, E.; Ahmed, S.I.; Devol, A.H. 1995. Aerobic and anaerobic decomposition of organic matter in marine sediment: which is fastest? Limnol. Oceanog. 40(8): $1430-1437$.

Kristensen, E. \& Holmer, M. 2001. Decomposition of plant materials in marine sediment exposed to different electron acceptors $\left(\mathrm{O}_{2}, \mathrm{NO}_{3}^{-}\right.$, and $\left.\mathrm{SO}_{4}{ }^{-2}\right)$, with emphasis on substrate origin, degradation kinetics, and role of bioturbation. Geochim. Cosmoch. Acta 65: 419-433.

Kristensen, E. \& Kostka, J.E. 2004. Macrofaunal burrows and irrigation in marine sediment: microbiological and biogeochemical interactions. In: Interactions between Macro- and Microorganisms in Marine Sediments, E. Kristensen, J.E. Kostka, R. Haese (edit's), American Geophysical Union, Washington, DC. 390 pp.

Lai, X.; Zeng, X.; Fang, S.; Huang, Y.; Cao, L.; Zhou, S. 2006. Denaturing gradient gel electrophoresis (DGGE) analysis of bacterial community composition in deepsea sediments of the South China Sea. World J. Microbiol. Biotechnol. 22: $1337-1345$.

Laima, M.J.C.; Matthiesen, H.; Lund-Hansen, L.C. \& Christiansen, C. 1998. Resuspension studies in cylindrical microcosms: Effects of stirring velocity on the dynamics of redox sensitive elements in a coastal sediment. Biogeochemistry 43: 293-309. 
Larson, F.; Petersen, D.G.; Dahllöf, I.; Sundbäck, K. 2007. Combined effects of an antifouling biocide and nutrient status on a shallow-water microbenthic community. Aquat. Microb. Ecol. 48: 277-294.

Lavigne, C.; Juniper, S.K.; Silverberg, N. 1997. Spatio-temporal variability in benthic microbial activity and particle flux in the Laurentian Trough. Deep-sea Res. I 44(11): 1793-1813.

Lebaron, P.; Servais, P.; Troussellier, M.; Courties, C.; J., Vives-Rego; Muyzer, G.; Bernard, L.; Guindulain, T.; Schäfer, H.; Stackebrandt, E. 1999. Changes in bacterial community structure in seawater mesocosms differing in their nutrient status. Aquat. Microb. Ecol. 19: 255-267.

Leloup, J.; Fossing, H.; Kohls, K.; Holmkvist, L.; Borowski, C.; Jørgensen, B.B. 2009. Sulfate-reducing bacteria in marine sediment (Aarhus Bay, Denmark): abundance and diversity related to geochemical zonation. Environ. Microbiol. 11(5): 1278-1291.

Linares, F. 2006. Effect of dissolved free amino acids (DFAA) on the biomass and production of microphytobenthic communities. J. Exp. Mar. Biol. Ecol. 330: 469-481.

Llobet-Brossa, H.; Rosselló-Mora, R.; Amann, R.I. 1998. Microbial community composition of Wadden Sea sediments as revealed by fluorescent in situ hybridization. Appl. Environ. Microbiol. 64: 2691-2696.

López-García, P.; Duperron, S.; Philippot, P.; Foriel, J.; Susini, J.; Moreira, D. 2003. Bacterial diversity in hydrothermal sediment and epsilonproteobacterial dominance in experimental microcolonizers at the Mid-Atlantic Ridge. Environ. Microbiol. 5: 961-976.

Lorenzen, C.J. 1967. Determination of chlorophyll and phaeopigments: spectrophotometric equations, Limnol. Oceanogr. 12: 343-346.

Luna, G.M.; Manini, E.; Danovaro, R. 2002. Large fraction of dead and inactive bacteria in coastal marine sediments: comparison of protocols for determination and ecological significance. Appl. Environm. Microbiol. 68: 3509-3513.

Luna, G.M.; Dell'Anno, A.; Giuliano, L.; Danovaro, R. 2004. Bacterial diversity in deep Mediterranean sediments: relationship with the active bacterial fraction and substrate availability. Environ. Microbiol. 6: 745-753.

Madigan, M. T.; Martinko, J. M.; Parker, J. 1997. Nutrition and metabolism. In: Brock Biology of Microorganisms, 8th edn, Prentice Hall, New Jersey. pp. 111-150. 
Mahiques, M.M. 1995. Dinâmica sedimentar atual nas enseadas da região de Ubatuba, Estado de São Paulo. Bolm. Inst. Oceanogr. 43(2): 111-122.

Mahiques, M.M.; Tessler, M.G.; Furtado, V.V. 1998. Characterization of energy gradient in enclosed Bays of Ubatuba region, South-eastern Brazil. Estuar. Coast. Shelf Sci. 47: 431-446.

Mahiques, M.M.; Tessler, M.G.; Ciotti, A.M.; Silveira, I.C.; Sousa, S.H.M.; Figueira, R.C.L.; Tassinari, C.C.G.; Furtado, V.V.; Passos, R.F. 2004. Hydrodynamically driven patterns of recent sedimentation in the shelf and upper slope off Shoutheast Brazil. Cont. Shelf. Res. 24: 1685-1697.

Maire, O.; Duchêne, J.-C.; Rosenberg, R.; Braga de Mendonça Jr, J.; Grémare, A. 2006. Effects of food availability on sediment reworking in Abra ovata and Abra nitida. Mar. Ecol. Prog. Ser. 319: 135-153.

Martiny, J.B.; Bohannan, B.J.; Brown, J.H.; Colwell, R.K.; Fuhrman, J.A.; Green, J.L.; Horner-Devine, M.C.; Kane, M.; Krumins, J.A.; Kuske, C.R.; Morin, P.J.; Naeem, S.; Ovreås, L.; Reysenbach, A.L.; Smith, V.H.; Staley, J.T. 2006. Microbial biogeography: putting microorganisms on the map. Nat. Rev. Microbiol. 4: 102-112.

Mather, I.D. \& Parkes, R.J. 2000. Bacterial profiles in sediments of the eastern flank of the Juan de Fuca ridge, sites 1026 and 10271. In: Fisher, A.; Davis, E.E.; Escutia, C. (Eds.) Proceedings of the Ocean Drilling Program, Scientific Results. 168(13): 162-165.

Mayer, L.M. 1994. Relationships between mineral surfaces and organic carbon concentrations in soils and sediments. Chem. Geol. 114: 347-363.

Meyer-Reil, L.A. 1983. Benthic response to sedimentation events during autumn to spring at shallow water station in the Western Kiel Bight. II. Analysis of benthic bacterial populations. Mar. Biol. 77: 247-256.

Meyers, P.A. 1997. Organic geochemical proxies of paleoceanographic, paleolimnologic, and paleoclimatic processes. Org. Chem. 27: 213-250.

Middelboe, M.. Søndergaard, M.; Letarte, Y.; Borch., N.H. 1995. Attached and freeliving bacteria: production and polymer hydrolysis during a diatom bloom. Microb. Ecol. 29: 231-248. 
Mills, H. J.; Hunter, E.; Humphrys, M.; Kerkhof, L.; Mcguinness, L.; Huettel, M.; Kostka, J.E. 2008. Characterization of nitrifying, denitrifying, and overallbacterial communities in permeable marine sediments of the northeastern Gulf of Mexico. Appl. Environ. Microbiol. 74: 4440-4453.

Molari, M.; Giovannelli, D.; d'Errico, G.; Manini, E. 2012. Factors influencing prokaryotic community structure composition in sub-surface coastal sediments. Estuar. Coast. Shelf Sc. 97: 141-148.

Moraes, P.C. 2007. Dinâmica bacteriana em sedimentos costeiros de Ubatuba, São Paulo. Dissertação de Mestrado. Universidade de São Paulo, Instituto Oceanográfico. $87 \mathrm{p}$.

Mußmann, M.; Ishii, K.; Rabus, R.; Amann, R. 2005. Diversity and vertical distribution of cultured and uncultured Deltaproteobacteria in an intertidal mud flat of the Wadden Sea. Environ. Microbiol. 2005. 7(3): 405-418.

Musat, N.; Werner, U.; Knittel, K.; Kolb, S.; Dodenhof, T.; van Beusekom, J.E.; de Beer, D.; Dubilier, N.; Amann, R. 2006. Microbial community structure of sandy intertidal sediments in the North Sea, Sylt-Romo Basin, Wadden Sea. Syst. Appl. Microbiol. 29: 333-348.

Muyzer, G.; Waal, E.C.; Uitterlinden, A.G. 1993. Profiling of complex microbial populations by denaturing gradient gel electrophoresis analysis of polymerase chain reactionamplified genes encoding for $16 \mathrm{~S}$ rRNA. Appl. Environ. Microbiol. 59: 695-700.

Nascimento, F.J.A.; Karlson, A.M.L.; Näslund, J.; Gorokhova, E. 2009. Settling cyanobacterial blooms do not improve growth conditions for soft bottom meiofauna. J. Exp. Mar. Biol. Ecol. 368: 138-146.

Nealson, K.H. 1997. Sediment bacteria: who's there, what are they doing, and what's new? Ann. Rev. Earth Planet. Sci. 25: 403-434.

Obernosterer, I.; Lami, R.; Larcher, M.; Batailler, N.; Catala, P.; Labaron, P. 2009. Linkage between bacterial carbon processing and the structure of the active bacterial community at a coastal site in the NW Mediterranean Sea. Microb. Ecol. 59, 428-435.

Oliveira, A.J.F.C.; Hollnagel, H.C.; Mesquita, H.S.M.; Fontes, R.F.C. 2007. Physical, chemical and microbiological characterization of the intertidal sediments of Pereque Beach, Guarujá (SP), Brazil. Mar. Pol. Bul. 54: 921-927. 
Orphan, V.J., House, C.H., Hinrichs, K.U., McKeegan, K.D.; DeLong, E.F. 2001. Methane-Consuming Archaea Revealed by Directly Coupled Isotopic and Phylogenetic Analysis. Science 293: 484-487.

O’Sullivan, L.A.; Weightman, A.J.; Fry, J.C. 2002. New degenerate CytophagaFlexibacter-Bacteroides specific 16S ribosomal DNA targeted oligonucleotide probes reveal high bacterial diversity in river Taff epilithon. Appl. Environ. Microbiol. 68: 201-210.

Pace, N.R. 1997. A molecular view of microbial diversity and thevbiosphere. Science 276: 734-740.

Pachiadaki, M.G.; Lykousis, V.; Stefanou, E.G.; Kormas, K.A. 2010. Prokaryotic community structure and diversity in the sediments of an active submarine mud volcano (Kazan mud volcano, East Mediterranean Sea). FEMS Microbiol. Ecol. 72: 429-444.

Parkes, R.J.; Cragg, B.A.; Wellsbury, P. 2000. Recent studies on bacterial populations and processes in subseafloor sediments: A review. Hydrogeol. J. 8: 11-28.

Pereira, C.O. 2008. Caracterização molecular da fração lipídica da matéria orgânica do sedimento da região costeira de Ubatuba, SP. Trabalho de Conclusão de Curso, Universidade de São Paulo, Instituto Oceanográfico.

Pete, R.; Davidson, K.; Hart, M.; Gutierrez, T.; Miller, A.E.J. 2010. Diatom derived dissolved organic matter as a driver of bacterial productivity: The role of nutrient limitation. J. Exp. Mar. Biol. Ecol. 391: 20-26.

Pfannkuche, O.; Sommer, S.; Kähler, A. 2000. Coupling between phytodetritus deposition and the small-sized benthic biota in the dep Arabian Sea: analyses of biogenic sediment compounds. Deep-Sea Res. II. 47: 2805-2833.

Pinhassi, J.; Azam, F.; Hempälä, J.; Long, R.A.; Martinez, J.; Zweifel, U.L.; Hagström, Å. 1999. Coupling between bacterioplankton species composition, population dynamics, and organic matter degradation. Aquat. Microb. Ecol. 17: 13-26.

Piza, F.F.; Prado, P.I.; Manfio, G.P. 2004. Investigation of bacterial diversity in Brazilian tropical estuarine sediments reveals high actinobacterial diversity. Antonie Leeuwenhoek. 86: 317-328.

Plante-Cuny, M.R. 1978. Pigments photosynthétiques et production primaire des fonds meubles néritiques d'une région tropicale (Nosy-Bé, Madagascar). Trav. Doc. ORSTOM 96: 1-359. 
Polymenakou, P.N.; Bertilsson, S.; Tselepides, A.; Stephanou, E.G. 2005a. Links between geographic location, environmental factors, and microbial community composition in sediments of the Eastern Mediterranean Sea. Microb. Ecol. 49: 367-378.

Polymenakou, P.N.; Pusceddu, A.; Tselepides, A.; Polychronaki, T.; Giannakourou, A.; Fiordelmondo, C.; Hatziyanni, E.; Danovaro, R. 2005b. Benthic microbial abundance and activities in an intensively trawled ecosystem (Thermaikos Gulf, Aegean Sea). Cont. Shelf Res. 25: 2570-2584.

Polymenakou, P.N.; Fragkioudakia, G.; Tselepidesa, A. 2007. Bacterial and organic matter distribution in the sediments of the Thracian Sea (NE Aegean Sea). Cont. Shelf Res. 27: 2187-2197.

Polymenakou, P.N.; Lampadariou, N.; Mandalakis, M.; Tselepides, A. 2009. Phylogenetic diversity of sediment bacteria from the southern Cretan margin, Eastern Mediterranean Sea. Syst. Appl. Microbiol. 32: 17-26.

Porter, E.T.; Mason, R.P.; Sanford, L.P. 2010. Effect of tidal resuspension on benthicpelagic coupling in an experimental ecosystem study. Mar. Ecol. Prog. Ser. 413: $33-53$.

Powell, S.M.; Bowman, J.P.; Snape, I.; Satark, J.S.; 2003. Microbial community variation in pristine and polluted nearshore Antarctic sediments. FEMS Microb. Ecol. 45: 135-145.

Puddu, A.; Zoppini, A.; Fazi, S.; Rosati, M.; Amalfitano, S.; Magaletti, E. 2003. Bacterial uptake of DOM released from P-limited phytoplankton. FEMS Micro. Ecol. 46: 257-268.

Pusceddu, A.; Grémareb, A.; Escoubeyroub, K.; Amourouxb, J.M.; Fiordelmondo, C.; Danovaro, R. 2005. Impact of natural (storm) and anthropogenic (trawling) sediment resuspension on particulate organic matter in coastal environments. Cont. Shelf. Res. 25: 2506-2520.

Quéric, N.V.; Softwede, T.; Arntz, W.E. 2004. Application of a rapid direct viable count method to deep-sea sediment bacteria. J. Microbiol. Methods. 57: 351367.

Quintana, C.O. 2004. Impactos da bioturbação na estrutura e distribuição vertical na infauna no sublitoral raso da Ilha Anchieta e Enseada do Flamengo (Ubatuba, SP). Dissertação de Mestrado. Universidade de São Paulo, Instituto Oceanográfico. $172 \mathrm{p}$. 
Quintana, C.O. 2008. Relações entre as comunidades bênticas e a matéria orgânica sedimentar: respostas à qualidade dos recursos alimentares e influência na diagênese recente. Tese de Doutorado. Universidade de São Paulo, Instituto Oceanográfico, São Paulo. 182p.

Ramette, A. \& Tiedje, J.M. 2007. Biogeography: an emerging cornerstone for understanding prokaryotic diversity, ecology, and evolution. Microb. Ecol. 53: 197-207.

Rappe, M.S. \& Giovannoni, S.J. 2003. The uncultured microbial majority. Annu. Rev. Microbiol. 57: 369-394.

Ravenschlag, K.; Sahm, K.; Pernthaler, J.; Amann, R. 1999. High bacterial diversity in permanently cold marine sediments. Appl. Environ. Microbiol. 65(9): 39823989.

Ravenschlag, K.; Sahm, K.; Knoblauch, C.; Jorgensen, B.B.; Amann, R. 2000. Community structure, cellular rRNA content, and activity of sulfate-reducing bacteria in marine arctic sediments. Appl. Environ. Microbiol. 66: 3592-3602.

Ravenschlag, K.; Sahm, K.; Amann, R. 2001. Quantitative molecular analysis of the microbial community in marine Arctic sediments (Svalbard). Appl. Environ. Microb. 67: 387-395.

Riemann, L.; Steward, G.F.; Azam, F. 2000. Dynamics of bacterial community composition and activity during a mesocosm diatom bloom. Appl. Environ. Microbiol. 66: 578-587.

Rink, B.; Seeberger, S.; Martens, T.; Duerselen, C.; Simon, M.; Brinkhoff, T. 2007. Effects of phytoplankton bloom in a coastal ecosystem on the composition of bacterial communities. Aquat. Microb. Ecol. 48: 47-60.

Ritzrau, W. \& Graf, G. 1992. Increase of microbial biomass in the benthic turbidity zone of Kiel Bight after resuspension by a storm event. Limnol. Oceanogr. 37: 1081-1086.

Rocha, G.R.A; Rossiwongtschowshi, C.L.D.B.; Pires-Vannin, A.M.S; Jarreteichmann, A. 2003. Seasonal budgets of organic matter in the Ubatuba shelf system, southeastern Brazil. I. Planktonic and benthic components. Oceanologica Acta. 26(5/6): 487-495.

Rooney-Varga, J.N.; Giewat, M.W.; Savin, M.C.; Sood, S.; LeGresley, M.; Martin, J.L.; 2005. Links between phytoplankton and bacterial community dynamics in a coastal marine environment. Microb. Ecol. 49: 163-175. 
Rosselló-Mora, R.; Thamdrup, B.; Schaefer, H.; Weller, R.; Amann, R. 1999. The response of the microbial community of marine sediments to organic carbon input under anaerobic conditions. Syst. Appl. Microbiol. 22: 237-248.

Rusch, A.; Huettel, M.; Reimers, C.E.; Taghon, G.L.; Fuller, C.M. 2003. Activity and distribution of bacterial populations in Middle Atlantic Bight shelf sands. Microb. Ecol. 44: 89-100.

Sahm, K.; Knoblauch, C.; Amann, R. 1999a. Phylogenetic affiliation and quantification of psychrophilic sulfatereducing isolates in marine arctic sediments. Appl. Environ. Microbiol. 65: 3976-3981.

Sahm, K.; MacGregor, B.J.; Jørgensen, B.B.; Stahl, D.A. 1999b. Sulphate reduction and vertical distribution of sulphate-reducing bacteria quantified by rRNA slot-blot hybridization in a coastal marine sediment. Environ. Microbiol. 1(1): 65-74.

Saldanha-Corrêa, F.M.P. \& Gianesella-Galvão, S.M.F. 2004. A microcosm approach on the potencial effects of the vertical mixing of water masses over the primary productivity and phytoplankton biomass in the southern brazilian coastal region. Braz. J. Oceanogr. 52: 167-182.

Saldanha, P.C. 2008. Avaliação ambiental através da utilização do fitoplâncton. Estudo de caso: Ilha Guaíba - Mangaratiba - RJ. Dissertação de Mestrado. Universidade do Estado do Rio de Janeiro. Faculdade de Engenharia.

Sanguinetti, C.J.; Dias Neto, E.; Simpson, A.J.G. 1994. Rapid silver staining and recovery of PCR products separated on polyacrylamide gels. Biotechniques. 17: 915-919.

Sass, H.; Cypionka, H.; Babenzien, H.-D. 1997. Vertical distribution of sulfate-reducing bacteria at the oxic-anoxic interface in sediments of the oligotrophic Lake Stechlin. FEMS Microbiol. Ecol. 22: 245-255.

Sassi, R. \& Kutner, M.B. 1982. Variação Sazonal do Fitoplâncton da Região do Saco da

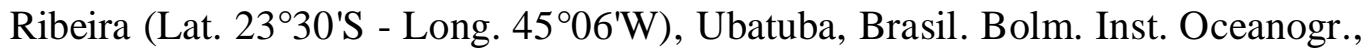
São Paulo. 31: 29-42.

Schäfer, H.; Abbas, B.; Witte, H.; Muyzer, G. 2002. Genetic diversity of 'satellite' bacteria present in cultures of marine diatoms. FEMS Microbiol. Ecol. 42: 2535.

Schäfer, H.; Ferdelman, T.G.; Fossing, H.; Muyzer, G. 2007. Microbial diversity in deep sediments of the Benguela upwelling system. Aquatic. Microbiol. Ecol. 50: $1-9$. 
Sheppard, S.K. \& Lloyd, D. 2002. Direct mass spectrometric measurement of gases in soil monoliths. J. Microbiol. Methods. 50: 175-188.

Shiah, F.-K.; Liu, K.-K.; Kao, S.-J.; Gong, G.-C. 2000. The coupling of bacterial production and hydrography in the southern East China Sea: spatial patterns in spring and fall. Cont. Shelf Res. 20: 459-477.

Shimeta, J.; Amos. C.L.; Beaulieu, S.E.; Katz, S.L. 2003. Resuspension of benthic protists at subtidal coastal sites with differing sediment composition. Mar. Ecol. Prog. Ser. 259: 103-115.

Silva, F.S.; Pereira, D.C.; Nuñez, L.S.; Krepsk, N.; Fontana, L.F.; Baptista Neto, J.A.; Crapez, M.A.C. 2008. Bacteriological study of the superficial sediments of Guanabara Bay, RJ, Brazil. Braz. J. Oceanogr. 56(1): 13-22.

Silveira I.C.; Schmidt, C.K.; Campos, E.J.D.; Godoi, S.S.; Ikeda, Y. 2000. A corrente do Brasil ao largo da costa leste brasileira. Ver. Bras. Oceanogr. 48(2): 171-183.

Sloth, N.P.; Riemann, B.; Nielsen, L.P.; Blackburn, T.H. 1996. Resilience of pelagic and benthic microbial communities to sediment resuspension in a coastal ecosystem, Knebel vig, Denmark. Estuar. Coast. Shelf Sci. 42: 405-415.

Smetacek, V. Plankton characteristics. 1988. In: Postma, H.; Zylstra, J.J. (Eds.). Ecosystems of the world. v.2 Continental Shelves. Elsevier, Amsterdan, p. 93130.

Smith, D.C.; Steward, G.F.; Long, R.A.; Azam, F. 1995. Bacterial mediation of carbon fluxes during a diatom bloom in a mesocosm. Deep-Sea Res. II. 42: 75-97.

Smith, Jr. K.L.; Baldwin, R.J.; Karl, D.M.; Boetius, A. 2002. Benthic community responses to pulses in pelagic food supply: North Pacific Subtropical Gyre. Deep-sea Res. I. 49: 971-990.

Stach, J.E.M.; Maldonado, L.A.; Masson, D.G.; Ward, A.C.; Goodfellow, M.; Bull, A.T. 2003. Statistical approaches to estimating bacterial diversity in marine sediments. Environ. Microbiol. 69: 6189-6200.

Stach, J.E.M. \& Bull, A.T. 2005. Estimating and comparing the diversity of marine actinobacteria. Antonie van Leeuwenhoek. 87: 3-9.

Ståhlberg, C.; Bastviken, D.; Svensson, B.H.; Rahm, L. 2006. Mineralisation of organic matter in coastal sediments at different frequency and duration of resuspension. Est. Coast. Shelf Sc. 70: 317-325. 
Stefanija, S.; Mladen, S.; Nada, K. 2009. The influence of organic matter and phytoplankton pigments on the distribution of bacteria in sediments of Kaštela Bay (Adriatic Sea). Scientia Marina. 73(1): 83-94.

Stevens, H.; Brinkhoff, T.; Simon, M. 2005. Composition of free-living, aggregateassociated and sediment surface-associated bacterial communities in the German Wadden Sea. Aquat. Microb. Ecol. 38: 15-30.

Stocum, E.T. \& Plante, C.J. 2006. The effect of artificial defaunation on bacterial assemblages of intertidal sediments. J. Exp. Mar. Biol. Ecol. 337: 147-158.

Stoeck, T. \& Kröncke, T. 2001. Influence of particle mixing on vertical profiles of chlorophyll a and bacterial biomass in sediments of the German Bight, Oyster Ground and Dogger Bank (North Sea). Est. Coast. Shelf Sci. 52(6): 783-795.

Strickland, J.D.H. \& Parsons, T.R. 1972. A Practical Handbook of Sea- Water Analysis, Fish. Res. Board Can. Bull., Canada, 2nd ed.

Suess, E. 1976. Nutrients near the depositional interface. In: McCave, N. (ed.). The benthic boundary layer. Plenum Press, New York, pp. 57-79.

Suess, E. 1980. Particulate organic carbon flux in the oceans - surface productivity and oxygen utilization. Nature. 288: 260-263.

Sun, M.-Y.; Lee, C.; Aller, R.C. 1993. Anoxic and oxic degradation of ${ }^{14}$ C-labeled chloropigments and a ${ }^{14} \mathrm{C}$-labeled diatom in Long Island Sound sediments. Limnol. Oceanogr. 38: 1438-1451.

Sun, M.-Y.; Aller, R.C.; Lee, C. 1994. Spatial and temporal distributions of sedimentary chloropigments as indicators of benthic processes in Long Island Sound. J. Mar. Res. 52: 149-176.

Sun, F.-L.; Wang, Y.-S.; Wu, M.-L.; Wang, Y.-T.; Li, Q.P. 2012. Spatial and vertical distribution of bacteria in the Pearl River estuary sediment. Afr. J. Biotechnol. 11(9): 2256-2266.

Susini-Zillmann, S.M. 1990. Distribuição sazonal do fitoplâncton na radial entre a ilha Anchieta e ilha Vitória da região de Ubatuba, São Paulo. Dissertação de Mestrado. Universidade de São Paulo, Instituto Oceanográfico, São Paulo. 2v.

Tengberg, A.; Almroth, E.; Hall, P. 2003. Resuspension and its effects on organic carbon recycling and nutrient exchange in coastal sediments: in situ measurements using new experimental technology. J. Exp. Mar. Biol. Ecol. 285286: $119-142$. 
Ter Braak, C.J.F. \& Smilauer, P. 2002. CANOCO reference manual and CanoDraw for Windows User's guide: Software for Canonical Community Ordination (version 4.5). Microcomputer Power, Ithaca NY.

Thamdrup, B. \& Fleischer, S. 1998. Temperature dependence of oxygen respiration, nitrogen mineralization, and nitrification in Arctic sediments. Aquatic. Microb. Ecol. 15: 191-199.

Thomsen, L.; Graf, G.; Martens, V.; Steen, E. 1994. An instrument for sampling water from the benthic boundary-layer. Cont. Shelf Res. 14 (7-8): 871-882.

Timmermann, K.; Banta, G. T.; Johnsen, A. R.; Andersen, O. 2008. Effects of the polychaetes Arenicola marina and Nereis diversicolor on microbial pyrene mineralization. Aquat. Microb. Ecol. 50: 197-207.

Torsvik, V.; Goksoyr, J.; Daae, F.L. 1990. High diversity in DNA of soil bacteria. Appl. Environ. Microbiol. 56: 782-787.

Turnewitsch, R.; Domeyer, B.; Graf, G. 2007. Experimental evidence for an effect of early-diagenetic interaction between labile and refractory marine sedimentary organic matter on nitrogen dynamics. J. Sea Res. 57: 270-280.

Urakawa, H.; Kita-Tsukamoto, K.; Ohwada, K. 1999. Microbial diversity in marine sediments from Sagami Bay and Tokyo Bay, Japan, as determined by 16S rRNA gene analysis. Microbiology. 145: 3305-3315.

Urakawa, H.; Yoshida, T.; Nishimura, M.; Ohwada, K. 2000. Characterization of depthrelated population variation in microbial communities of a coastal marine sediment using $16 \mathrm{~S}$ rDNA-based approaches and quinone profiling. Environ. Microbiol. 2: 542-554.

Urakawa, H.; Yoshida, T.; Nishimura, M.; Ohwada, K. 2001. Characterization of microbial communities in marine surface sediments by terminal-restriction fragment length polymorphism (T-RFLP) analysis and quinone profiling. Mar. Ecol. Prog. Ser. 220: 47-57.

Vangriesheim, A. \& Khripounoff, A. 1990. Near-bottom particle concentration and flux-temporal variations observed with sediment traps and nepholometer on the Meriadzek Terrace, Bay of Biscay. Progr. Oceanogr. 24(1-4): 103-116.

Venter, J.C.; Remington, K.; Heidelberg, J.F.; Halpern, A.L.; Rusch, D.; Eisen, J.A.; Wu, D.; Paulsen, I.; Nelson, K.E.; Nelson, W. 2004. Environmental genome shotgun sequencing of the Sargasso Sea. Science. 304: 66-74. 
Veuger, B. \& Middelburg, J.J. 2007. Incorporation of nitrogen from amino acids and urea by benthic microbes: role of bacteria versus algae and coupled incorporation of carbon. Aquat. Microb. Ecol. 48: 35-46.

Viitasalo-Frösén, S.; Lainel, A.O.; Lehtiniemil, M. 2009. Habitat modification mediated by motile surface stirrers versus semi-motile burrowers: potential for a positive feedback mechanism in a eutrophied ecosystem. Mar. Ecol. Prog. Ser. 376: $21-$ 32.

von Wintzingerode, F.; Göbel, U.B.; Stackebrandt, E. 1997. Determination of microbial diversity in environmental samples: pitfalls of PCR-based rRNA analysis. FEMS Microbiol. Rev. 21: 213-229.

Wainright. SC. 1987. Stimulation of heterotrophic microplankton production by resuspended marine sediments. Science. 238: 1710-1712.

Wainright, S.C. 1990. Sediment-to-water fluxes of particulate material and microbes by resuspension and their contribution to the planktonic food web. Mar. Ecol. Prog. Ser. 62: 271-281.

Wainright, S.C. \& Hopkinson Jr., C.S. 1997. Effects of sediment resuspension on organic matter processing in coastal environments: a simulation model. J. Mar. System. 11: 353-368.

Wakeham, S. \& Canuel, E. 2006. Degradation and preservation of organic matter in arine sediments. In: Volkman, J.K. (ed.) Marine organic matter: biomarkers, isotopes and DNA. Springer, pp. 295-322.

Wakeham, S.G.; Lee, C.; Hedges, J.I.; Hernes, P.J.; Peterson, M.L. 1997. Molecular indicators of diagenetic status in marine organic matter. Geochim. Cosmochim. Acta 61: 5363-5369.

Walsh, J.J. 1991. Importance of continental margins in the marine biogeochemical cycling of carbon and nitrogen. Nature. 350: 53-55.

Ward, A.C. \& Bora, N. 2006. Diversity and biogeography of marine actinobacteria. Curr. Opin. Microbiol. 9: 279-286.

Watling, L.; Findlay, R.H.; Mayer, L.M.; Schick, D.F. 2001. Impact of scallop drag on the sediment chemistry, microbiota, and fauna assemblages of shallow subtidal marine benthic community. 2001. J. Sea Res. 46: 309-324.

Weller, R.; Glöckner, F.O.; Amann, R. 2000. 16S rRNA-targeted oligonucleotide probes for the in situ detection of members of the phylum CytophagaFlavobacterium-Bacteroidetes. Syst. Appl. Microbiol., 23: 107-114. 
Werner, U.; Billerbeck, M.; Polerecky, L.; Franke, U.; Huettel, M.; van Beusekom, J.E.E.; Beer, D. 2006. Spatial and temporal patterns of mineralization rates and oxygen distribution in a permeable intertidal sand flat (Sylt, Germany). Limnol. Oceanogr. 51(6): 2549-2563.

Willkomm, M.; Schlüssel1, A.; Reiz, E.; Arndt, H. 2008. Effects of microcurrents in the boundary layer on the attachment of benthic heterotrophic nanoflagellates. Aquat. Microb. Ecol. 48: 179-184.

Wobus, A.; Bleul, C.; Maassen, S.; Scheerer, C.; Schuppler, M.; Jacobs, E.; Roske, I. 2003. Microbial diversity and functional characterization of sediments from reservoirs of different trophic state. FEMS Microbiol. Ecol. 46: 331-347.

Wollast, R. 2002. Continental margins_-review of geochemical settings. In Wefer, G.; Billett, D.; Hebbeln, D.; Jørgensen, B.B.; Schlüter, M.; van Weering, T.C.E. [eds.], Ocean margin systems. Springer.

Yoshinaga, M.Y. 2006. Origem e composição da matéria orgânica e a dinâmica da comunidade microbiana em sedimentos superficiais de ecossistemas marinhos da costa sudeste do Brasil. Tese de Doutorado. Universidade de São Paulo, Instituto Oceanográfico. 133p.

Yoshinaga, M.Y.; Sumida, P.Y.G.; Wakeham, S. 2008. Lipids biomarkers in surface sediments from unusual coastal upwelling area from the SW Atlantic Ocean. Org. Geochem. 39: 1385-1399.

Zehnder, A.J.B.; Stumm, W. 1988. Geochemistry and biogeochemistry of anaerobic habitats. In: Zehnder, A.J.B. (Ed.) Biology of anaerobic microorganisms. John Wiley \& Sons, New York, p 1-38.

Zeng, R.; Zhao, J.; Zhang, R.; Lin, N. 2005. Bacterial community in sediment from the western Pacific Warm Pool and its relationship to environment. China Environ. Sci. 48: 282-90. 


\section{ANEXO}

Afiliação filogenética dos genotipos detectados a partir das bibliotecas genômicas utilizando BLAST (GenBank).

\begin{tabular}{|c|c|c|c|c|c|c|c|c|c|c|c|c|c|c|c|}
\hline Sequência com relação mais próxima no GenBank & $\mathrm{T} 24 \mathrm{~h}$ & & P24h & & T48h & & P48h & & R48h & & R120 & & $\mathrm{C} 120$ & & Gupo Filogenético \\
\hline & OTU & $\mathrm{S}$ & OTU & $\mathrm{S}$ & OTU & $\mathrm{S}$ & OTU & $\mathrm{S}$ & OTU & $\mathrm{S}$ & OTU & $\mathrm{S}$ & OTU & $\mathrm{S}$ & \\
\hline Acidocella facilis strain PW2 16S ribosomal RNA, partial sequence. & 1 & $100 \%$ & & & & & & & & & & & & & Alphaproteobacteria \\
\hline Actibacter sediminis strain JC2129 16S ribosomal RNA, partial sequence & & & & & & & & & 1 & $99 \%$ & & & & & Bacteroidete \\
\hline Actinocatenispora sera strain KV-744 16S ribosomal RNA, partial sequence & & & & & & & 1 & $93 \%$ & & & & & & & Actinobacteria \\
\hline Aestuariibacter halophilus strain JC2043 16S ribosomal RNA, partial sequence & & & & & 1 & $96 \%$ & & & & & & & & & Gammaproteobacteria \\
\hline Alcanivorax venustensis strain ISO4 $16 \mathrm{~S}$ ribosomal RNA, complete sequence & 1 & $88 \%$ & & & & & & & & & & & & & Gammaproteobacteria \\
\hline Alkalilimnicola halodurans strain 34Alc 16S ribosomal RNA, partial sequence & & & & & & & & & & & 2 & $93 \%$ & 2 & $90 \%$ & Gammaproteobacteria \\
\hline Alkalispirillum mobile strain DSM 12769 16S ribosomal RNA, partial sequence & & & & & & & & & & & & & 1 & $96 \%$ & Gammaproteobacteria \\
\hline Allochromatium minutissimum strain MSU $16 \mathrm{~S}$ ribosomal RNA, partial seqence & & & & & & & & & & & & & 1 & $91 \%$ & Gammaproteobacteria \\
\hline Alteromonas litorea strain TF-22T 16S ribosomal RNA, partial sequence & & & & & 1 & $94 \%$ & & & & & & & & & Gammaproteobacteria \\
\hline Alteromonas macleodii strain 107 16S ribosomal RNA, partial sequence & 4 & $98 \%$ & & & & & & & & & & & & & Gammaproteobacteria \\
\hline Alteromonas marina strain SW-47 16S ribosomal RNA, partial sequence & 1 & $90 \%$ & & & & & & & & & & & & & Gammaproteobacteria \\
\hline Anaerobaculum mobile strain NGA $16 \mathrm{~S}$ ribosomal RNA, complete sequence & & & & & 3 & $97 \%$ & 4 & $100 \%$ & & & & & & & Synergistetes \\
\hline Anaerolinea thermolimosa strain IMO-1 $16 \mathrm{~S}$ ribosomal RNA, partial sequence & & & & & & & 1 & $90 \%$ & & & 1 & $91 \%$ & & & Cloroflexi \\
\hline Anaerolinea thermophila strain UNI-1 16S ribosomal RNA, partial sequence & & & & & & & & & & & 2 & $90 \%$ & & & Cloroflexi \\
\hline $\begin{array}{l}\text { Anaeromyxobacter dehalogenans } 2 \mathrm{CP}-1 \text { strain } 2 \mathrm{CP}-1 \text { 16S ribosomal RNA, complete } \\
\text { sequence }\end{array}$ & & & 2 & $88 \%$ & & & 1 & $90 \%$ & & & 1 & $89 \%$ & & & Deltaproteobacteria \\
\hline Anderseniella baltica strain :BA141 16S ribosomal RNA, partial sequence & & & & & & & & & 1 & $92 \%$ & & & & & Alphaproteobacteria \\
\hline Aquisalimonas asiatica strain : CG12 16S ribosomal RNA, complete sequence & & & & & & & & & & & & & 1 & $91 \%$ & Gammaproteobacteria \\
\hline Aurantimonas kwangyangensis strain CW5 $16 \mathrm{~S}$ ribosomal RNA, partial sequence & & & & & & & & & & & & & & & Alphaproteobacteria \\
\hline Bacillus horti strain K13 16S ribosomal RNA, partial sequence. & & & & & & & & & 1 & $91 \%$ & & & & & Firmicutes \\
\hline Bacillus mannanilyticus strain AM-001 16S ribosomal RNA, complete sequence & & & 1 & $100 \%$ & & & & & & & & & & & Firmicutes \\
\hline Bellilinea caldifistulae 16S ribosomal RNA, partial sequence. & 1 & $90 \%$ & 2 & $91 \%$ & & & & & 1 & $90 \%$ & 1 & $89 \%$ & 1 & $90 \%$ & Cloroflexi \\
\hline Blastococcus saxobsidens strain BC448 16S ribosomal RNA, partial sequence & & & & & 1 & $90 \%$ & 1 & $90 \%$ & & & & & & & Actinobacteria \\
\hline Blastopirellula marina DSM 3645 strain SH 10616 S ribosomal RNA, complete sequence & & & & & & & 1 & $88 \%$ & & & & & & & Planctomycetes \\
\hline Caldilinea aerophila DSM 14535 strain STL-6-01 16S ribosomal RNA, partial sequence & & & & & & & 2 & $90 \%$ & 4 & $92 \%$ & 3 & $90 \%$ & & & Cloroflexi \\
\hline Caldithrix abyssi strain LF13 16S ribosomal RNA, partial sequence. & 1 & $89 \%$ & & & & & & & & & & & 1 & $92 \%$ & Caldithrix \\
\hline Cellvibrio mixtus subsp. mixtus strain ACM 2601 16S ribosomal RNA, patial sequence & & & & & & & & & & & 1 & $90 \%$ & & & Gammaproteobacteria \\
\hline Chlorobium phaeovibrioides strain 2631 16S ribosomal RNA, partial sequence & & & & & & & & & & & & & 1 & $95 \%$ & Clorobi \\
\hline Chondromyces lanuginosus strain Sy t2 $16 \mathrm{~S}$ ribosomal RNA, partial sequence & & & 1 & $92 \%$ & & & & & & & & & & & Deltaproteobacteria \\
\hline Conexibacter woesei DSM 14684 strain ID131577 16S ribosomal RNA, partial sequence & & & & & & & 2 & $92 \%$ & & & & & & & Actinobacteria \\
\hline Crocinitomix catalasitica strain IFO 15977 16S ribosomal RNA, partial sequence & & & & & & & & & & & 1 & $89 \%$ & & & Bacteroidete \\
\hline Dasania marina strain KOPRI 20902 16S ribosomal RNA, partial sequence & & & & & & & 1 & $91 \%$ & & & 1 & $90 \%$ & 1 & $90 \%$ & Gammaproteobacteria \\
\hline Desulfatibacillum aliphaticivorans strain CV2803 16S ribosomal RNA, partial sequence & & & & & & & & & 3 & $93 \%$ & & & & & Deltaproteobacteria \\
\hline Desulfobacterium anilini strain Ani1 16S ribosomal RNA, partial sequence & & & 1 & $90 \%$ & & & & & 1 & $90 \%$ & & & 1 & $91 \%$ & Deltaproteobacteria \\
\hline Desulfobacterium catecholicum strain NZva20 16S ribosomal RNA, partial sequence & 3 & $90 \%$ & 3 & $91 \%$ & & & & & 4 & $90 \%$ & 2 & $92 \%$ & 1 & $89 \%$ & Deltaproteobacteria \\
\hline Desulfobacula toluolica Tol2 strain DSM 7467 16S ribosomal RNA, partial sequence & & & 1 & $95 \%$ & & & & & & & & & & & Deltaproteobacteria \\
\hline
\end{tabular}




\begin{tabular}{|c|c|c|c|c|c|c|c|c|c|c|c|c|c|c|c|}
\hline \multirow[t]{2}{*}{ Sequência com relação mais próxima no GenBank } & \multicolumn{2}{|l|}{ T24h } & \multicolumn{2}{|l|}{ P24h } & \multicolumn{2}{|l|}{ 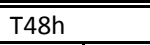 } & \multicolumn{2}{|l|}{ P48h } & \multicolumn{2}{|l|}{ R48h } & \multicolumn{2}{|c|}{ R120h } & \multicolumn{2}{|c|}{ C120h } & \multirow[t]{2}{*}{ Gupo Filogenético } \\
\hline & OTU & $\mathrm{s}$ & OTU & $\mathrm{S}$ & OTU & $\mathrm{S}$ & OTU & $\mathrm{S}$ & OTU & $\mathrm{S}$ & OTU & $\mathrm{S}$ & OTU & $\mathrm{S}$ & \\
\hline Desulfobulbus elongatus strain FP 16S ribosomal RNA, partial sequence & & & & & & & & & & & & & 1 & $90 \%$ & Deltaproteobacteria \\
\hline $\begin{array}{l}\text { Desulfobulbus japonicus strain Pro1 (= JCM 14043, = DSM 18378) 16S ribosomal RNA, } \\
\text { partial sequence }\end{array}$ & & & & & & & 1 & $92 \%$ & 1 & $93 \%$ & & & & & Deltaproteobacteria \\
\hline Desulfobulbus mediterraneus strain 86FS1 16S ribosomal RNA, partial sequence & 1 & $91 \%$ & & & & & 2 & $94 \%$ & 5 & $92 \%$ & & & 2 & $94 \%$ & Deltaproteobacteria \\
\hline Desulfocapsa thiozymogenes strain Bra2 $16 \mathrm{~S}$ ribosomal RNA, partial sequence & & & & & & & 1 & $90 \%$ & & & & & & & Deltaproteobacteria \\
\hline Desulfococcus biacutus strain DSM 5651 16S ribosomal RNA, partial sequence & & & & & 2 & $93 \%$ & & & & & & & & & Deltaproteobacteria \\
\hline Desulfocurvus vexinensis strain VNs36 16S ribosomal RNA, partial sequence & 1 & $90 \%$ & 1 & $89 \%$ & & & & & & & & & & & Deltaproteobacteria \\
\hline Desulfofaba fastidiosa strain P2 16S ribosomal RNA, partial sequence & & & & & & & & & & & 1 & $90 \%$ & & & Deltaproteobacteria \\
\hline Desulfofrigus fragile strain LSV21 16S ribosomal RNA, partial sequence & & & 1 & $98 \%$ & & & & & & & & & & & Deltaproteobacteria \\
\hline Desulfoglaeba alkanexedens ALDC strain ALDC $16 \mathrm{~S}$ ribosomal RNA, partial sequence & & & & & & & & & & & 1 & $90 \%$ & & & Deltaproteobacteria \\
\hline Desulfomicrobium norvegicum strain DSM 1741 16S ribosomal RNA, partial sequence & 1 & $90 \%$ & & & & & & & & & & & & & Deltaproteobacteria \\
\hline Desulfomonile limimaris strain DCB-M 16S ribosomal RNA, partial sequence & 1 & $91 \%$ & & & & & 2 & $90 \%$ & & & 2 & $90 \%$ & 1 & $90 \%$ & Deltaproteobacteria \\
\hline Desulfonema magnum str. Montpellier strain 4 be 1316 S ribosomal RNA, partial sequence & & & & & 1 & $93 \%$ & & & & & 1 & $90 \%$ & & & Deltaproteobacteria \\
\hline $\begin{array}{l}\text { Desulfopila aestuarii strain MSL86 (= JCM 14042, = DSM 18488) 16S ribosomal RNA, } \\
\text { partial sequence }\end{array}$ & & & 2 & $92 \%$ & 1 & $90 \%$ & 1 & $90 \%$ & 2 & $91 \%$ & & & & & Deltaproteobacteria \\
\hline Desulforhopalus singaporensis strain S'pore T1 16S ribosomal RNA, partial sequence & & & 2 & $93 \%$ & & & 1 & $90 \%$ & & & & & & & Deltaproteobacteria \\
\hline Desulfosarcina cetonica strain $48016 \mathrm{~S}$ ribosomal RNA, partial sequence & & & & & 1 & $89 \%$ & & & & & & & & & Deltaproteobacteria \\
\hline Desulfosarcina ovata strain oXyS1 16S ribosomal RNA, partial sequence & & & & & & & & & 1 & $90 \%$ & & & 2 & $93 \%$ & Deltaproteobacteria \\
\hline Desulfosarcina variabilis $16 \mathrm{~S}$ ribosomal RNA, partial sequence. & & & & & & & 2 & $90 \%$ & & & & & & & Deltaproteobacteria \\
\hline Desulfovibrio marinus strain E-2 $16 \mathrm{~S}$ ribosomal RNA, partial sequence & & & & & & & 1 & $89 \%$ & & & & & & & Deltaproteobacteria \\
\hline Desulfovirga adipica strain TsuA1 16S ribosomal RNA, partial sequence & & & & & 1 & $92 \%$ & & & & & & & & & Deltaproteobacteria \\
\hline Desulfurivibrio alkaliphilus AHT2 strain AHT2 $16 \mathrm{~S}$ ribosomal RNA, partial sequence & & & & & & & & & 2 & $90 \%$ & & & & & Deltaproteobacteria \\
\hline Desulfuromonas acetexigens $16 \mathrm{~S}$ ribosomal RNA, partial sequence. & & & & & & & & & & & 1 & $94 \%$ & & & Deltaproteobacteria \\
\hline Desulfuromonas alkaliphilus strain Z-0531 16S ribosomal RNA, partial sequence & & & 3 & $94 \%$ & & & & & 2 & $90 \%$ & & & 2 & $91 \%$ & Deltaproteobacteria \\
\hline Desulfuromonas svalbardensis strain $11216 \mathrm{~S}$ ribosomal RNA, partial sequence & & & 1 & $95 \%$ & & & & & 1 & $91 \%$ & & & 3 & $95 \%$ & Deltaproteobacteria \\
\hline Desulfuromonas thiophila strain NZ27 16S ribosomal RNA, partial sequence & & & & & & & 1 & $93 \%$ & & & 1 & $93 \%$ & & & Deltaproteobacteria \\
\hline Desulfuromusa ferrireducens strain $10216 \mathrm{~S}$ ribosomal RNA, partial sequence & & & & & & & & & & & 1 & $95 \%$ & & & Deltaproteobacteria \\
\hline Desulfuromusa succinoxidans strain Gylac $16 \mathrm{~S}$ ribosomal RNA, partial sequence & & & & & & & 1 & $85 \%$ & & & & & & & Deltaproteobacteria \\
\hline Donghicola xiamenensis strain Y-2 $16 \mathrm{~S}$ ribosomal RNA, partial sequence & & & & & 1 & $97 \%$ & & & & & & & & & Alphaproteobacteria \\
\hline Ectothiorhodosinus mongolicus strain M9 16 S ribosomal RNA, partial sequence & 1 & $100 \%$ & & & & & & & & & 3 & $91 \%$ & & & Gammaproteobacteria \\
\hline Ectothiorhodospira variabilis strain : WN22 $16 \mathrm{~S}$ ribosomal RNA, partial sequence & & & & & & & & & 1 & $90 \%$ & & & 1 & $89 \%$ & Gammaproteobacteria \\
\hline Erythrobacter aquimaris strain SW-110 16 S ribosomal RNA, partial sequence & 1 & $99 \%$ & & & 1 & $98 \%$ & & & & & & & & & Alphaproteobacteria \\
\hline Fabibacter halotolerans strain UST030701-097 16S ribosomal RNA, partial sequence & & & & & & & & & 2 & $92 \%$ & & & & & Bacteroidete \\
\hline Ferribacterium limneticum strain cda-1 165 ribosomal RNA, complete sequence & & & 1 & $87 \%$ & & & & & & & & & & & Betaproteobacteria \\
\hline Ferrimonas marina strain A4D-4 16S ribosomal RNA, partial sequence sequence. & & & & & & & & & & & 1 & $91 \%$ & & & Gammaproteobacteria \\
\hline Ferruginibacter lapsinanis strain HU1-HG42 $16 \mathrm{~S}$ ribosomal RNA, partial sequence & & & & & & & & & & & & & 1 & $93 \%$ & Bacteroidete \\
\hline Fluviicola taffensis DSM 16823 strain RW262 16S ribosomal RNA, partial sequence & & & 1 & $91 \%$ & & & & & & & & & & & Bacteroidete \\
\hline Fulvivirga kasyanovii strain KMM 6220 16S ribosomal RNA, partial sequence & 3 & $92 \%$ & 2 & $92 \%$ & & & & & & & & & & & Bacteroidete \\
\hline Gaetbulibacter marinus strain IMCC1914 16S ribosomal RNA, partial sequence & & & 1 & $92 \%$ & & & & & & & & & & & Bacteroidete \\
\hline Geobacter argillaceus strain G12 16S ribosomal RNA, partial sequence & & & & & & & 2 & $89 \%$ & 1 & $90 \%$ & & & 1 & $89 \%$ & Deltaproteobacteria \\
\hline
\end{tabular}




\begin{tabular}{|c|c|c|c|c|c|c|c|c|c|c|c|c|c|c|c|}
\hline \multirow[t]{2}{*}{ Sequência com relação mais próxima no GenBank } & \multicolumn{2}{|l|}{ T24h } & \multicolumn{2}{|l|}{ P24h } & \multicolumn{2}{|l|}{ T48h } & \multicolumn{2}{|l|}{$\mathrm{P} 48 \mathrm{~h}$} & \multicolumn{2}{|l|}{ R48h } & \multicolumn{2}{|c|}{ R120h } & \multicolumn{2}{|c|}{ C120h } & \multirow[t]{2}{*}{ Gupo Filogenético } \\
\hline & OTU & $\mathrm{S}$ & OTU & $\mathrm{S}$ & OTU & $\mathrm{S}$ & OTU & $\mathrm{S}$ & OTU & $\mathrm{S}$ & OTU & $\mathrm{s}$ & OTU & $\mathrm{s}$ & \\
\hline Geobacter bemidjiensis Bem strain Bem $16 \mathrm{~S}$ ribosomal RNA, partial sequence & & & & & & & & & 2 & $96 \%$ & & & & & Deltaproteobacteria \\
\hline Geobacter bremensis strain Dfr1 16S ribosomal RNA, partial sequence & & & & & & & & & 2 & $89 \%$ & 1 & $90 \%$ & & & Deltaproteobacteria \\
\hline Geobacter pelophilus strain Dfr2 $16 \mathrm{~S}$ ribosomal RNA, partial sequence & & & & & 1 & $89 \%$ & & & & & & & 1 & $89 \%$ & Deltaproteobacteria \\
\hline Geothrix fermentans strain H5 16S ribosomal RNA, partial sequence. & & & & & 1 & $91 \%$ & & & & & 1 & $89 \%$ & & & Acidobacteria \\
\hline Haliangium tepidum strain SMP-10 16S ribosomal RNA, partial sequence & & & & & & & & & & & 1 & $92 \%$ & 1 & $92 \%$ & Deltaproteobacteria \\
\hline Haliea rubra strain CM41_15a 16S ribosomal RNA, partial sequence. & 2 & $94 \%$ & 4 & $94 \%$ & & & 2 & $90 \%$ & 1 & $90 \%$ & & & & & Gammaproteobacteria \\
\hline Haliea salexigens strain 3X/A02/235 16S ribosomal RNA, partial sequence & & & 1 & $94 \%$ & & & 3 & $95 \%$ & & & 2 & $94 \%$ & & & Gammaproteobacteria \\
\hline Halochromatium roseum strain : JA134 16 S ribosomal RNA, partial sequence & & & & & & & & & & & 1 & $90 \%$ & & & Gammaproteobacteria \\
\hline Henriciella marina strain Iso4 16 S ribosomal RNA, partial sequence. & 1 & $98 \%$ & & & & & & & & & & & & & Alphaproteobacteria \\
\hline Hoeflea marina strain LMG 128 16S ribosomal RNA, partial sequence. & & & & & & & & & & & & & 1 & $90 \%$ & Alphaproteobacteria \\
\hline Humicoccus flavidus strain DS-52 16S ribosomal RNA, partial sequence & & & & & & & 1 & $90 \%$ & & & & & & & Actinobacteria \\
\hline Hyphomicrobium hollandicum strain IFAM KB-677 16S ribosomal RNA, partial sequence & & & & & & & & & 1 & $90 \%$ & & & & & Alphaproteobacteria \\
\hline Hyphomicrobium sulfonivorans strain S1 $16 \mathrm{~S}$ ribosomal RNA, partial sequence & & & & & & & & & & & 1 & $95 \%$ & & & Alphaproteobacteria \\
\hline Hyphomicrobium zavarzinii strain ZV-622 16S ribosomal RNA, partial sequence & 1 & $95 \%$ & & & 2 & $94 \%$ & 1 & $99 \%$ & 1 & $91 \%$ & 1 & $93 \%$ & & & Alphaproteobacteria \\
\hline lamia majanohamensis strain NBRC 102561 16S ribosomal RNA, partial sequence & & & & & & & 1 & $90 \%$ & & & & & & & Actinobacteria \\
\hline Ilumatobacter fluminis strain YM22-133 16S ribosomal RNA, partial sequence & 1 & $100 \%$ & & & 1 & $98 \%$ & & & & & & & 1 & $98 \%$ & Actinobacteria \\
\hline Kaistia soli strain 5YN9-8 $16 \mathrm{~S}$ ribosomal RNA, partial sequence. & & & & & & & & & & & 1 & $90 \%$ & & & Alphaproteobacteria \\
\hline Lacinutrix algicola strain AKS293 16 S ribosomal RNA, partial sequence & & & 1 & $90 \%$ & & & & & & & & & & & Bacteroidete \\
\hline Lamprocystis roseopersicina strain DSM 229 16S ribosomal RNA, partial sequence & & & & & 1 & $90 \%$ & & & & & & & & & Gammaproteobacteria \\
\hline Leisingera aquimarina strain : LMG 24366 = R-26159 16S ribosomal, partial sequence & & & & & 1 & $97 \%$ & & & 1 & $96 \%$ & & & & & Alphaproteobacteria \\
\hline Leisingera methylohalidivorans strain MB2 $16 \mathrm{~S}$ ribosomal RNA, partial sequence & & & & & 1 & $96 \%$ & & & & & & & & & Alphaproteobacteria \\
\hline Leptolinea tardivitalis strain YMTK-2 $16 \mathrm{~S}$ ribosomal RNA, partial sequence & & & & & & & 1 & $90 \%$ & & & & & & & Cloroflexi \\
\hline Levilinea saccharolytica strain KIBI-1 16S ribosomal RNA, partial sequence & & & & & & & 1 & $90 \%$ & & & & & & & Cloroflexi \\
\hline Lishizhenia caseinilytica strain UST040201-001 16S ribosomal RNA, partial sequence & & & & & 1 & $90 \%$ & & & & & & & & & Bacteroidete \\
\hline Longilinea arvoryzae $16 \mathrm{~S}$ ribosomal RNA, partial sequence sequence. & & & & & & & 3 & $91 \%$ & & & 2 & $90 \%$ & & & Cloroflexi \\
\hline Longispora albida strain K97-0003 16S ribosomal RNA, partial sequence & & & & & & & 1 & $90 \%$ & & & & & & & Actinobacteria \\
\hline Luteolibacter algae strain A5J-41-2 $16 \mathrm{~S}$ ribosomal RNA, partial sequence & & & 1 & $90 \%$ & & & & & & & & & & & Verrucomicrobia \\
\hline Maribaculum marinum strain P38 16S ribosomal RNA, partial sequence. & 3 & $97 \%$ & & & & & & & & & & & & & Alphaproteobacteria \\
\hline Maricaulis maris strain ATCC 15268 16S ribosomal RNA, partial sequence & 1 & $90 \%$ & & & & & & & & & & & & & Alphaproteobacteria \\
\hline Marichromatium bheemlicum strain : JA124 16S ribosomal RNA, partial sequence & & & & & & & 1 & $91 \%$ & 1 & $90 \%$ & & & 2 & $91 \%$ & Gammaproteobacteria \\
\hline Marichromatium gracile strain : BN 5210 = DSM 203 16S ribosomal, partial sequence & & & & & 1 & $93 \%$ & & & & & 1 & $93 \%$ & & & Gammaproteobacteria \\
\hline Marichromatium purpuratum strain $98416 \mathrm{~S}$ ribosomal RNA, partial sequence & & & & & & & & & 1 & $91 \%$ & & & & & Gammaproteobacteria \\
\hline Marinifilum fragile strain JC2469 16S ribosomal RNA, partial sequence & & & 1 & $90 \%$ & & & & & 1 & $90 \%$ & & & 3 & $91 \%$ & Bacteroidete \\
\hline Marinobacter excellens strain KMM $380916 \mathrm{~S}$ ribosomal RNA, complete sequence & & & 2 & $91 \%$ & & & & & & & & & & & Gammaproteobacteria \\
\hline Marinobacter flavimaris strain SW-145 16S ribosomal RNA, partial sequence & & & & & & & & & 1 & $90 \%$ & 2 & $96 \%$ & 1 & $98 \%$ & Gammaproteobacteria \\
\hline Marinobacter goseongensis strain En6 16S ribosomal RNA, partial sequence & & & & & & & & & & & 1 & $96 \%$ & 2 & $93 \%$ & Gammaproteobacteria \\
\hline Marinobacter lacisalsi strain FP2.5 16S ribosomal RNA, partial sequence & & & & & & & & & 1 & $90 \%$ & & & & & Gammaproteobacteria \\
\hline Marinobacter maritimus strain : CK47 16S ribosomal RNA, partial sequence & 1 & $95 \%$ & & & & & & & & & & & & & Gammaproteobacteria \\
\hline Marinobacter salsuginis strain SD-14B 16S ribosomal RNA, partial sequence & 2 & $97 \%$ & & & 1 & $97 \%$ & & & & & & & & & Gammaproteobacteria \\
\hline
\end{tabular}




\begin{tabular}{|c|c|c|c|c|c|c|c|c|c|c|c|c|c|c|c|}
\hline \multirow[t]{2}{*}{ Sequência com relação mais próxima no GenBank } & \multicolumn{2}{|l|}{ T24h } & \multicolumn{2}{|l|}{ P24h } & \multicolumn{2}{|l|}{ T48h } & \multicolumn{2}{|l|}{ P48h } & \multicolumn{2}{|l|}{ R48h } & \multicolumn{2}{|c|}{ R120h } & \multicolumn{2}{|c|}{ C120h } & \multirow[t]{2}{*}{ Gupo Filogenético } \\
\hline & OTU & $\mathrm{s}$ & OTU & $\mathrm{s}$ & OTU & $\mathrm{s}$ & OTU & $\mathrm{s}$ & OTU & $\mathrm{s}$ & OTU & $\mathrm{s}$ & OTU & $\mathrm{s}$ & \\
\hline Marinobacter sediminum strain R65 16S ribosomal RNA, partial sequence & 6 & $93 \%$ & & & 2 & $96 \%$ & & & & & & & & & Gammaproteobacteria \\
\hline Marinobacterium nitratireducens strain CN44 16S ribosomal RNA, partial sequence & & & & & 1 & $94 \%$ & 1 & $90 \%$ & & & & & & & Gammaproteobacteria \\
\hline Marinomonas mediterranea strain MMB1 165 ribosomal RNA, complete sequence & 1 & $90 \%$ & & & & & & & & & & & & & Gammaproteobacteria \\
\hline Marinomonas sp. BSi20328 strain BSi20328 16S ribosomal RNA, partial sequence & & & & & & & & & & & 2 & $91 \%$ & & & Gammaproteobacteria \\
\hline Marinoscillum pacificum strain MRN461 16S ribosomal RNA, partial sequence & & & & & 2 & $90 \%$ & & & & & & & & & Bacteroidete \\
\hline Marivirga tractuosa DSM 4126 strain IFO 1598916 S ribosomal RNA, partial sequence & & & 3 & $95 \%$ & & & & & & & & & & & Bacteroidete \\
\hline Marivita cryptomonadis strain CL-SK44 16S ribosomal RNA, partial sequence & & & & & & & & & & & & & 1 & $94 \%$ & Alphaproteobacteria \\
\hline Marivita litorea strain CL-JM1 16S ribosomal RNA, partial sequence. & & & & & & & 1 & $97 \%$ & 1 & $96 \%$ & & & & & Alphaproteobacteria \\
\hline Marixanthomonas ophiurae strain KMM $304616 \mathrm{~S}$ ribosomal RNA, partial sequence & & & 1 & $92 \%$ & & & & & & & & & & & Bacteroidete \\
\hline Melitea salexigens strain $5 I X / A 01 / 13116 \mathrm{~S}$ ribosomal RNA, partial sequence & & & & & & & 1 & $90 \%$ & & & 2 & $90 \%$ & 2 & $90 \%$ & Gammaproteobacteria \\
\hline Methylobacter marinus strain A45 $16 \mathrm{~S}$ ribosomal RNA, partial sequence & & & & & & & & & & & 1 & $91 \%$ & & & Gammaproteobacteria \\
\hline Methylobacter whittenburyi strain 1521 of Whittenbury 165 ribosomal, partial sequence & 1 & $90 \%$ & & & & & & & & & & & & & Gammaproteobacteria \\
\hline Methylocaldum gracile strain VKM-14L 16S ribosomal RNA, partial sequence & & & & & & & & & & & 1 & $89 \%$ & & & Gammaproteobacteria \\
\hline Methylococcus capsulatus strain Texas $16 \mathrm{~S}$ ribosomal RNA, partial sequence & & & 1 & $90 \%$ & & & & & & & & & 1 & $90 \%$ & Gammaproteobacteria \\
\hline Methylohalomonas lacus strain HMT 1 16S ribosomal RNA, partial sequence & & & & & 1 & $90 \%$ & & & & & & & & & Gammaproteobacteria \\
\hline Methylonatrum kenyense strain AMT $116 \mathrm{~S}$ ribosomal RNA, partial sequence & & & & & & & & & 1 & $90 \%$ & 1 & $90 \%$ & & & Gammaproteobacteria \\
\hline Methylophaga alcalica strain M39 16S ribosomal RNA, partial sequence & & & & & 1 & $94 \%$ & & & & & & & & & Gammaproteobacteria \\
\hline Methylophaga aminisulfidivorans $16 \mathrm{~S}$ ribosomal RNA, partial sequence & 5 & $93 \%$ & & & & & & & & & & & & & Gammaproteobacteria \\
\hline Methylophaga marina strain ATCC $3584216 \mathrm{~S}$ ribosomal RNA, partial sequence & 1 & $93 \%$ & & & 1 & $91 \%$ & 1 & $98 \%$ & & & & & & & Gammaproteobacteria \\
\hline Microbacterium lacticum strain DSM 20427 16S ribosomal RNA, partial sequence & & & & & & & 1 & $93 \%$ & & & & & & & Actinobacteria \\
\hline Microbulbifer agarilyticus strain JAMB A3 $16 \mathrm{~S}$ ribosomal RNA, partial sequence & & & & & 1 & $93 \%$ & & & & & & & & & Gammaproteobacteria \\
\hline Microbulbifer variabilis strain Ni-2088 $16 \mathrm{~S}$ ribosomal RNA, partial sequence & 1 & $91 \%$ & & & & & & & & & & & & & Gammaproteobacteria \\
\hline Natronincola histidinovorans strain Z-7940 16S ribosomal RNA, partial sequence & & & & & 1 & $90 \%$ & & & & & & & & & Firmicutes \\
\hline Natronocella acetinitrilica strain ANL 6-2 $16 \mathrm{~S}$ ribosomal RNA, partial sequence & & & 1 & $92 \%$ & & & & & & & & & & & Gammaproteobacteria \\
\hline Nautella italica strain : LMG 24365 16S ribosomal RNA, partial sequence & 1 & $100 \%$ & & & 1 & $97 \%$ & 1 & $99 \%$ & & & 1 & $90 \%$ & & & Alphaproteobacteria \\
\hline Neptuniibacter caesariensis strain MED92 $16 \mathrm{~S}$ ribosomal RNA, colplete sequence & & & 3 & $93 \%$ & 1 & $94 \%$ & 1 & $95 \%$ & & & & & & & Gammaproteobacteria \\
\hline Nitratifractor salsuginis DSM 16511 strain E9I37-1 16S ribosomal, partial sequence & & & 1 & $92 \%$ & & & & & & & & & & & Epsilonproteobacteria \\
\hline Nitratireductor basaltis strain J3 $16 \mathrm{~S}$ ribosomal RNA, partial sequence & 1 & $90 \%$ & & & & & & & & & & & 1 & $94 \%$ & Alphaproteobacteria \\
\hline Nitrospira moscoviensis strain NSP M-1 16 S ribosomal RNA, partial sequence & & & & & & & & & 1 & $92 \%$ & & & & & Nitrospirae \\
\hline $\begin{array}{l}\text { Novosphingobium pentaromativorans US6-1 strain US6-1 16S ribosomal, complete } \\
\text { sequence }\end{array}$ & 2 & $90 \%$ & & & & & & & & & & & & & Alphaproteobacteria \\
\hline Oceanibaculum indicum strain P24 16S ribosomal RNA, partial sequence & 2 & $91 \%$ & & & & & & & & & & & & & Alphaproteobacteria \\
\hline Oceanibulbus indolifex HEL-45 16S ribosomal RNA, partial sequence. & & & & & & & & & & & & & 1 & $90 \%$ & Alphaproteobacteria \\
\hline Oceanicola nanhaiensis strain SS011B1-20 16S ribosomal RNA, partial sequence & 2 & $92 \%$ & & & 1 & $91 \%$ & & & & & & & & & Alphaproteobacteria \\
\hline Oceanicola pacificus strain W11-2B $16 \mathrm{~S}$ ribosomal RNA, partial sequence & & & & & & & & & 1 & $90 \%$ & & & & & Alphaproteobacteria \\
\hline Oceanisphaera donghaensis strain BL1 16S ribosomal RNA, partial sequence & & & & & & & & & 1 & $90 \%$ & & & & & Gammaproteobacteria \\
\hline Owenweeksia hongkongensis strain UST20020801 16S ribosomal RNA, partial sequence & & & & & & & & & 1 & $90 \%$ & & & & & Bacteroidete \\
\hline Parvibaculum lavamentivorans strain DS-1 16S ribosomal RNA, partial sequence & 1 & $90 \%$ & & & 2 & $90 \%$ & & & & & & & & & Alphaproteobacteria \\
\hline Pedomicrobium australicum strain IFAM ST1306 16S ribosomal RNA, partial sequence & 1 & $93 \%$ & & & & & & & & & & & 2 & $90 \%$ & Alphaproteobacteria \\
\hline Pelagibius litoralis strain CL-UU02 16S ribosomal RNA, partial sequence & & & & & & & & & 2 & $91 \%$ & & & 1 & $92 \%$ & Alphaproteobacteria \\
\hline
\end{tabular}




\begin{tabular}{|c|c|c|c|c|c|c|c|c|c|c|c|c|c|c|c|}
\hline \multirow[t]{2}{*}{ Sequência com relação mais próxima no GenBank } & \multicolumn{2}{|l|}{ T24h } & \multicolumn{2}{|l|}{ P24h } & \multicolumn{2}{|l|}{ T48h } & \multicolumn{2}{|l|}{$\mathrm{P} 48 \mathrm{~h}$} & \multicolumn{2}{|l|}{ R48h } & \multicolumn{2}{|c|}{ R120h } & \multicolumn{2}{|c|}{$\mathrm{C} 120 \mathrm{~h}$} & \multirow[t]{2}{*}{ Gupo Filogenético } \\
\hline & OTU & $\mathrm{s}$ & OTU & $\mathrm{S}$ & OTU & $\mathrm{S}$ & OTU & $\mathrm{S}$ & OTU & $\mathrm{s}$ & OTU & $\mathrm{s}$ & OTU & $\mathrm{S}$ & \\
\hline Pelobacter acetylenicus strain WoAcy1 16 S ribosomal RNA, partial sequence & & & & & & & 1 & $90 \%$ & & & & & & & Deltaproteobacteria \\
\hline Pelobacter acidigallici strain DSM 2377 16S ribosomal RNA, partial sequence & & & 1 & $90 \%$ & & & & & & & & & & & Deltaproteobacteria \\
\hline Phaeobacter caeruleus strain : LMG 24369165 ribosomal RNA, partial sequence & 8 & $98 \%$ & & & 8 & $96 \%$ & 2 & $91 \%$ & & & & & & & Alphaproteobacteria \\
\hline Phaeobacter daeponensis strain TF-218 165 ribosomal RNA, partial sequence & $\mid 1$ & $90 \%$ & & & 1 & $98 \%$ & & & & & & & & & Alphaproteobacteria \\
\hline Photobacterium aquimaris strain LC2-065 (= NBRC 104633) 16S RNA, partial sequence & & & & & & & & & & & & & 1 & $91 \%$ & Gammaproteobacteria \\
\hline Photobacterium frigidiphilum strain SL13 16S ribosomal RNA, partial sequence & & & & & & & 1 & $95 \%$ & & & & & & & Gammaproteobacteria \\
\hline Planctomyces brasiliensis strain DSM $530516 \mathrm{~S}$ ribosomal RNA, partial sequence & 1 & $93 \%$ & 1 & $97 \%$ & & & & & & & & & & & Planctomycetes \\
\hline Planctomyces maris strain 534-30 16S ribosomal RNA, partial sequence & & & & & & & & & & & & & 1 & $88 \%$ & Planctomycetes \\
\hline $\begin{array}{l}\text { Planktothricoides raciborskii NIES-207 strain NIES-207 16S ribosomal RNA, partial } \\
\text { sequence }\end{array}$ & & & & & & & & & & & 1 & $90 \%$ & & & Cyanobacteria \\
\hline Ponticoccus litoralis strain CL-GR66 16S ribosomal RNA, partial sequence & & & & & 1 & $93 \%$ & & & & & & & & & Alphaproteobacteria \\
\hline $\begin{array}{l}\text { Prochlorococcus marinus subsp. pastoris str. PCC } 9511 \text { 16S ribosomal RNA, partial } \\
\text { sequence }\end{array}$ & & & 8 & \begin{tabular}{|l|l|}
$95-$ \\
$97 \%$ \\
\end{tabular} & & & 1 & $94 \%$ & & & 2 & $95 \%$ & & & Cyanobacteria \\
\hline Propionigenium maris strain DSM 9537 16S ribosomal RNA, partial sequence & & & 4 & $98 \%$ & & & 1 & $98 \%$ & & & 1 & $97 \%$ & & & Fusobacteria \\
\hline Pseudoalteromonas tetraodonis strain IAM 1416016 S ribosomal RNA, partial sequence & & & 1 & $100 \%$ & & & & & & & & & & & Gammaproteobacteria \\
\hline Pseudomonas pachastrellae strain KMM 330165 ribosomal RNA, partial sequence & & & & & & & & & & & 1 & $90 \%$ & & & Gammaproteobacteria \\
\hline Pseudomonas sabulinigri strain J64 16S ribosomal RNA, partial sequence & & & & & 1 & $90 \%$ & & & & & & & & & Gammaproteobacteria \\
\hline Rhabdochromatium marinum DSM 5261 16S ribosomal RNA, partial sequence & & & 1 & $100 \%$ & & & & & & & & & & & Gammaproteobacteria \\
\hline Rhodobium gokarnense strain : JA173 16 S ribosomal RNA, complete sequence & & & & & & & 2 & $93 \%$ & & & & & & & Alphaproteobacteria \\
\hline Rhodobium orientis strain MB312 $16 \mathrm{~S}$ ribosomal RNA, partial sequence & & & 2 & $90 \%$ & & & & & & & & & & & Alphaproteobacteria \\
\hline Rhodopseudomonas julia strain DSM 11549 16S ribosomal RNA, complete sequence & 3 & $90 \%$ & & & & & & & & & & & & & Alphaproteobacteria \\
\hline $\begin{array}{l}\text { Rhodospirillaceae bacterium YIM D812 strain YIM D812 16S ribosomal RNA, partial } \\
\text { sequence }\end{array}$ & & & & & & & & & 1 & $90 \%$ & & & & & Alphaproteobacteria \\
\hline Roseibacillus persicicus strain YM26-010 16S ribosomal RNA, partial sequence & & & 1 & $93 \%$ & & & & & & & & & & & Verrucomicrobia \\
\hline Roseivirga spongicola strain UST030701-084 16S ribosomal RNA, partial sequence & & & & & & & 2 & $91 \%$ & & & & & 1 & $90 \%$ & Bacteroidete \\
\hline Roseovarius aestuarii strain SMK-122 16S ribosomal RNA, partial sequence & 1 & $94 \%$ & & & & & & & & & & & & & Alphaproteobacteria \\
\hline Rubidibacter lacunae KORDI 51-2 strain KORDI 51-2 16S ribosomal RNA, partial sequence & & & & & & & 1 & $90 \%$ & & & & & & & Cyanobacteria \\
\hline Rubrimonas cliftonensis strain OCh $31716 \mathrm{~S}$ ribosomal RNA, partial sequence & & & & & & & & & 1 & $90 \%$ & & & & & Alphaproteobacteria \\
\hline Ruegeria atlantica strain IAM14463 16S ribosomal RNA, partial sequence & 1 & $97 \%$ & 2 & $97 \%$ & 5 & $98 \%$ & & & 1 & $93 \%$ & & & & & Alphaproteobacteria \\
\hline Ruegeria pomeroyi strain DSS-3 $16 \mathrm{~S}$ ribosomal RNA, complete sequence & 1 & $97 \%$ & 1 & $97 \%$ & 1 & $94 \%$ & & & & & & & & & Alphaproteobacteria \\
\hline Salisaeta longa strain S4-4 16S ribosomal RNA, partial sequence. & & & & & 2 & $90 \%$ & & & & & & & & & Bacteroidete \\
\hline Sediminibacter furfurosus strain MAOS-86 $16 \mathrm{~S}$ ribosomal RNA, partial sequence & & & & & & & 1 & $95 \%$ & & & & & & & Bacteroidete \\
\hline Shimia marina strain CL-TA03 $16 \mathrm{~S}$ ribosomal RNA, partial sequence. & & & & & & & 1 & $91 \%$ & & & 2 & $90 \%$ & & & Alphaproteobacteria \\
\hline Sinorhizobium terangae strain : LMG $783416 \mathrm{~S}$ ribosomal RNA, partial sequence & & & & & & & & & & & 1 & $90 \%$ & & & Alphaproteobacteria \\
\hline Spirochaeta halophila $16 \mathrm{~S}$ ribosomal RNA, complete sequence. & & & & & & & & & & & 2 & $90 \%$ & & & Spirochaetes \\
\hline Steroidobacter denitrificans strain FS 165 ribosomal RNA, partial sequence & & & & & 2 & $90 \%$ & & & & & & & & & Gammaproteobacteria \\
\hline Streptomyces mashuensis strain DSM40221 16S ribosomal RNA, complete sequence & 1 & $90 \%$ & & & & & & & & & & & & & Actinobacteria \\
\hline Streptomyces tricolor strain NBRC 15461 16S ribosomal RNA, partial sequence & & & 1 & $90 \%$ & & & & & & & & & & & Actinobacteria \\
\hline Syntrophobacter fumaroxidans strain MPOB 165 ribosomal RNA, partial sequence & & & & & & & & & & & & & 3 & $92 \%$ & Deltaproteobacteria \\
\hline Syntrophus gentianae strain HQgoe1 $16 \mathrm{~S}$ ribosomal RNA, partial sequence & & & & & & & & $90 \%$ & & & & & 1 & $90 \%$ & Deltaproteobacteria \\
\hline
\end{tabular}




\begin{tabular}{|c|c|c|c|c|c|c|c|c|c|c|c|c|c|c|c|}
\hline \multirow[t]{2}{*}{ Sequência com relação mais próxima no GenBank } & \multicolumn{2}{|l|}{$\overline{T 24 h}$} & \multicolumn{2}{|l|}{ P24h } & \multicolumn{2}{|l|}{ T48h } & \multicolumn{2}{|l|}{ P48h } & \multicolumn{2}{|l|}{ R48h } & \multicolumn{2}{|c|}{ R120h } & \multicolumn{2}{|c|}{ C120h } & \multirow[t]{2}{*}{ Gupo Filogenético } \\
\hline & OTU & $\mathrm{S}$ & OTU & $\mathrm{S}$ & OTU & $\mathrm{S}$ & OTU & $\mathrm{S}$ & OTU & $\mathrm{S}$ & OTU & $\mathrm{S}$ & OTU & $\mathrm{S}$ & \\
\hline Tenacibaculum litoreum strain CL-TF13 $16 \mathrm{~S}$ ribosomal RNA, partial sequence & & & 1 & $92 \%$ & & & & & & & & & & & Bacteroidete \\
\hline Thalassobius aestuarii strain JC2049 16S ribosomal RNA, partial sequence & & & & & & & & & 1 & $92 \%$ & & & & & Alphaproteobacteria \\
\hline $\begin{array}{l}\text { Thalassobius mediterraneus strain : CECT } 5383=\text { XSM19 16S ribosomal RNA, partial } \\
\text { sequence }\end{array}$ & 1 & $99 \%$ & & & 1 & $90 \%$ & & & & & & & & & Alphaproteobacteria \\
\hline $\begin{array}{l}\text { Thalassomonas viridans strain XOM5, CECT 5082, DSM } 1375316 \mathrm{~S} \text { ribosomal RNA, partial } \\
\text { sequence }\end{array}$ & & & 1 & $90 \%$ & & & & & & & & & & & Gammaproteobacteria \\
\hline Thermincola ferriacetica strain Z-0001 16S ribosomal RNA, partial sequence & & & & & & & & & & & & & 1 & $88 \%$ & Firmicutes \\
\hline Thioalkalispira microaerophila strain ALEN 1 16S ribosomal RNA, partial sequence & & & & & & & & & 1 & $92 \%$ & & & & & Gammaproteobacteria \\
\hline Thioalkalivibrio denitrificans strain ALD $16 \mathrm{~S}$ ribosomal RNA, partial sequence & & & 1 & $91 \%$ & 1 & $91 \%$ & & & 4 & $93 \%$ & 2 & $90 \%$ & & & Gammaproteobacteria \\
\hline $\begin{array}{l}\text { Thioalkalivibrio thiocyanodenitrificans ARhD } 1 \text { strain ARhD } 116 \mathrm{~S} \text { ribosomal RNA, partial } \\
\text { sequence }\end{array}$ & & & 1 & $90 \%$ & & & 1 & $91 \%$ & 4 & $90 \%$ & 1 & $91 \%$ & 2 & $91 \%$ & Gammaproteobacteria \\
\hline Thiococcus pfennigii strain $425016 \mathrm{~S}$ ribosomal RNA, partial sequence & & & 1 & $90 \%$ & & & & & & & & & & & Gammaproteobacteria \\
\hline Thiohalocapsa halophila strain $427016 \mathrm{~S}$ ribosomal RNA, partial sequence & 2 & $90 \%$ & & & & & & & & & & & & & Gammaproteobacteria \\
\hline Thiohalomonas nitratireducens strain HRHd 3sp $16 \mathrm{~S}$ ribosomal RNA, partial sequence & 1 & $90 \%$ & & & & & 1 & $90 \%$ & 1 & $90 \%$ & 3 & $91 \%$ & 2 & $90 \%$ & Gammaproteobacteria \\
\hline Thiohalophilus thiocyanatoxydans strain HRhD $216 \mathrm{~S}$ ribosomal RNA, partial sequence & & & 3 & $92 \%$ & 1 & $92 \%$ & & & & & & & & & Gammaproteobacteria \\
\hline Thiohalospira alkaliphila strain ALgr 6sp 16S ribosomal RNA, partial sequence & & & & & 1 & $91 \%$ & & & & & 1 & $93 \%$ & & & Gammaproteobacteria \\
\hline Tindallia texcoconensis strain IMP-300 16S ribosomal RNA, partial sequence & & & & & 1 & $90 \%$ & & & & & & & & & Firmicutes \\
\hline Tistrella mobilis strain JCM 21370 16S ribosomal RNA, partial sequence & & & & & 1 & $90 \%$ & & & & & 1 & $90 \%$ & & & Alphaproteobacteria \\
\hline Vibrio orientalis strain $71716 \mathrm{~S}$ ribosomal RNA, partial sequence. & & & 1 & $97 \%$ & & & & & & & & & & & Gammaproteobacteria \\
\hline Vibrio pomeroyi strain CAIM 578 16S ribosomal RNA, partial sequence & & & & & & & & & & & & & 1 & $90 \%$ & Gammaproteobacteria \\
\hline Winogradskyella arenosi strain R60 (=KMM 3968) 16S ribosomal RNA, partial sequence & & & & & 1 & $93 \%$ & & & 1 & $93 \%$ & & & & & Bacteroidete \\
\hline Winogradskyella poriferorum strain UST030701-295 16S ribosomal RNA, partial sequence & & & & & & & & & 1 & $94 \%$ & & & & & Bacteroidete \\
\hline não classificadas & 0 & & 1 & & 1 & & 2 & & 2 & & 2 & & 0 & & \\
\hline Total de sequências analisadas & 79 & & 79 & & 69 & & 69 & & \begin{tabular}{|l|}
73 \\
\end{tabular} & & 70 & & 59 & & \\
\hline
\end{tabular}

T. Tetrasselmis; P. Phaeodactylum; C. controle; R. ressuspensão; S \% de similaridade 